Editores

$$
\text { Jorge E. Elías-Caro }
$$

Consuelo Naranjo Orovio

\title{
MIGRACTONAS ANTILAMNAS
} I Trabajo, designtalitad v xenofobia

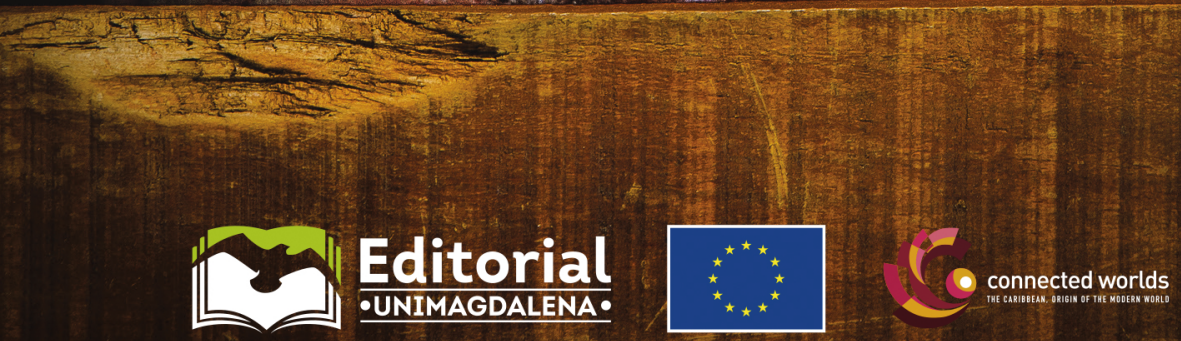



Migraciones antillanas 



\title{
Migraciones antillanas: trabajo, desigualdad y xenofobia
}

\author{
Jorge E. Elías-Caro \\ Consuelo Naranjo Orovio \\ Editores
}

Colección Humanidades y Artes

Serie: Historia
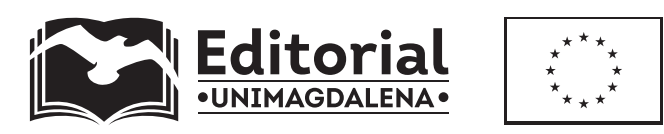
Catalogación en la publicación - Biblioteca Nacional de Colombia

Migraciones antillanas : trabajo, desigualdad y xenofobia / editores, Jorge E. Elías-Caro, Consuelo Naranjo Orovio. -- 1a ed. -- Santa Marta : Editorial Unimagdalena, 2021.

280 p. - (Colección Humanidades y Artes. Historia)

Incluye datos curriculares de los autores. -- Incluye referencias bibliográficas al final de cada capítulo.

ISBN 978-958-746-392-7 (impreso) -- 978-958-746-393-4 (pdf) -- 978-958-746-394-1 (e-pub)

1. Emigración e inmigración - Antillas 2. Migración de pueblos - Antillas 3. Problemas raciales Antillas 4. Antillas - Condiciones sociales I. Elías-Caro, Jorge Enrique, editor ed. II. Naranjo Orovio, Consuelo, editor ed. III. Serie

CDD: 304.809729 ed. 23

CO-BoBN-a 1077708

Primera edición, julio de 2021

2021 ๑ Universidad del Magdalena. Derechos Reservados.

Editorial Unimagdalena

Carrera 32 n. ${ }^{\circ} 22-08$

Edificio de Innovación y Emprendimiento

(57 - 605) 4381000 Ext. 1888

Santa Marta D.T.C.H. - Colombia

editorial@unimagdalena.edu.co

https://editorial.unimagdalena.edu.co/

Colección Humanidades y Artes, serie: Historia

Rector: Pablo Vera Salazar

Vicerrector de Investigación: Jorge Enrique Elías-Caro

Coordinador de Publicaciones y Fomento Editorial: Jorge Mario Ortega Iglesias

Diseño editorial: Luis Felipe Márquez Lora

Diagramación: Jeynner Kevin Páez Vélez

Diseño de portada: Andrés Felipe Moreno Toro

Corrección de estilo: Hernando García

Santa Marta, Colombia, 2021

ISBN: 978-958-746-392-7 (impreso)

ISBN: 978-958-746-393-4 (pdf)

ISBN: 978-958-746-394-1 (epub)

DOI: $10.21676 / 9789587463927$

Impreso y hecho en Colombia - Printed and made in Colombia

Xpress Estudio Gráfico y Digital S.A.S. - Xpress Kimpres (Bogotá)

Este libro se inserta en el proyecto europeo Connected Worlds: The Caribbean, Origin of Modern World. This project has received funding from the European Union's Horizon 2020 research and innovation programme under the Marie Sklodowska Curie grant agreement N. ${ }^{\circ} 823846$. This project is directed by professor Consuelo Naranjo Orovio, Institute of History-CSIC.

El contenido de esta obra está protegido por las leyes y tratados internacionales en materia de Derecho de Autor. Queda prohibida su reproducción total o parcial por cualquier medio impreso o digital conocido o por conocer. Queda prohibida la comunicación pública por cualquier medio, inclusive a través de redes digitales, sin contar con la previa y expresa autorización de la Universidad del Magdalena.

Las opiniones expresadas en esta obra son responsabilidad de los autores y no compromete al pensamiento institucional de la Universidad del Magdalena, ni genera responsabilidad frente a terceros. 


\section{Sumario}

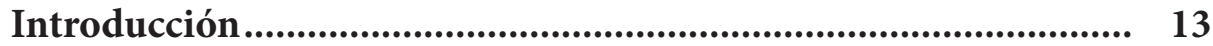

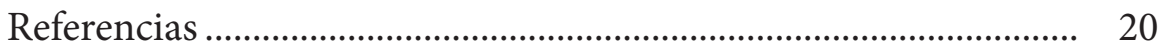

Los braceros jamaicanos en la industria azucarera cubana: el caso de la United Fruit Company ............................................. 23 Oscar Zanetti Lecuona

La United Fruit Company en el oriente cubano................................ 24

Expansión azucarera y fuerza de trabajo............................................ 26

Los braceros antillanos y la United Fruit ........................................... 33

Régimen laboral y condiciones de vida............................................ 37

Jamaicanos en tierras de la United Fruit ............................................ 45

Referencias ......................................................................................... 52

Inmigrantes antillanos en Cuba: discursos económicos, raciales e identitarios, 1910-1940 ....................................................... 55

Consuelo Naranjo Orovio

Discursos sobre la inmigración y la nación ....................................... 55

Política y legislación migratorias en Cuba ........................................ 62

Propuesta para seleccionar el tipo de inmigrante ............................ 65

Los últimos años de la inmigración antillana: las repatriaciones

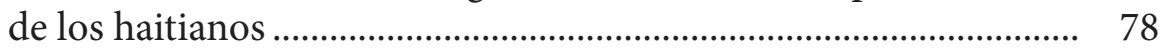

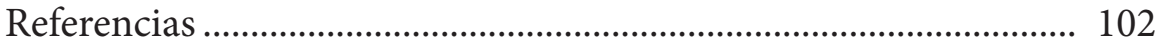


"Yumecas". West Indies workers en el enclave bananero de la United Fruit Company en el Magdalena (Caribe colombiano), 1900-1940

Jorge Enrique Elías-Caro

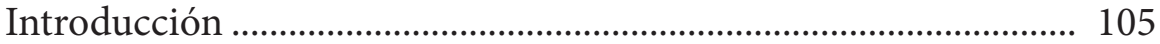

Lo que dice la historia y no hace visible la historiografía ............... 109

La migración antillana anglófona a la Zona Bananera del

Magdalena y el enclave de la UFCo .............................................. 112

Las familias yumecas. Características........................................... 130

Consideraciones finales ............................................................. 135

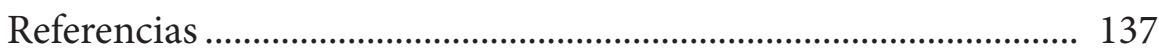

En sintonía con los tiempos: perfil ocupacional y división sexual del trabajo de la población afrocaribeña en Costa Rica durante la primera mitad del siglo XX........................................................ 139

Diana Senior Angulo

Introducción

Segmentación migratoria y laboral de las poblaciones

afrocaribeñas a partir de finales siglo XIX

División sexual del trabajo: dinámica de las relaciones

afrocaribeñas dentro y fuera del hogar.

Perfil ocupacional de mujeres y hombres afrocaribeños en sintonía con los tiempos de la primera mitad del siglo XX

Conclusiones.

Referencias

El Caribe hondureño y su negritud: ¿una amenaza para los obreros o un peligro para la nación?

Yesenia Martínez García

Introducción

Concesiones, discursos, legislación y manifestaciones

de rechazo por la presencia de trabajadores antillanos o negros

de habla inglesa.

Conclusiones.

Referencias 
Migraciones caribeñas de las colonias inglesas hacia Costa Rica y República Dominicana: procesos raciales y el impacto de las ideas de Garvey (1872-1950) .......................................................... 189

Reina Rosario

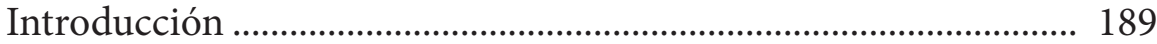

Hipótesis de partida ........................................................................ 191

Penetración del capital norteamericano en el Caribe:

la llegada de los antillanos británicos a Costa Rica

y República Dominicana ................................................................ 192

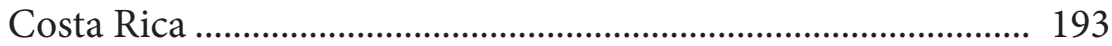

República Dominicana.................................................................. 195

Gestiones y fracasos de Costa Rica y República Dominicana para atraer inmigrantes caucásicos ................................................... 201

La similitud con el caso dominicano ............................................. 202

Políticas eugenésicas impuestas por Estados Unidos ....................... 206

Décadas del 30 al 50: reactivación del racismo bajo el tinte

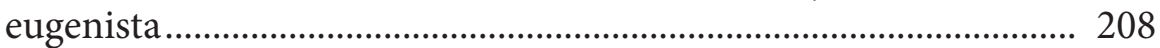

Asimilación forzada en la RD y segregación territorial en CR ...... 210 Influencia del movimiento garveyista en Limón, Costa Rica, y San Pedro de Macorís, República Dominicana ............................. 213

La UNIA en Limón ................................................................... 214

La UNIA en República Dominicana ....................................... 216

Comentarios finales .................................................................... 219

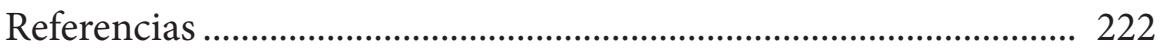

Infraestructura ferroviaria y migración en Panamá, siglos XIX y XX............................................................................................ 225

Juan Santiago Correa Restrepo

Introducción

Migración como temática subordinada en la historiografía general.................................................................................. 226

Trabajos sobre los procesos de construcción

de infraestructura.................................................................... 226

Trabajos sobre migrantes en la zona canalera ............................ 228

Trabajos sobre poblaciones migrantes específicas en el istmo de Panamá 
Migración e infraestructura del ferrocarril y del canal de Panamá …………………………………………………………... 236

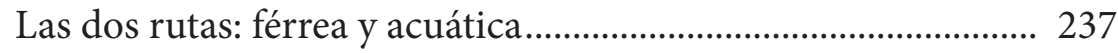

Trabajadores migrantes y locales ……………………………....... 240

A manera de comentario final .......................................................... 245

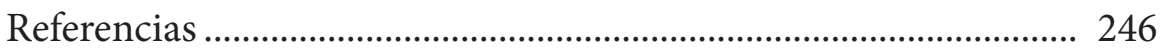

\section{Los haitianos de Miami: ¿̨una comunidad en vías}

de integración?

Cédric Audebert

Introducción

La formación de una comunidad etnocultural haitiana

en Miami

Una triple minoría inserta en la parte inferior

de la escala socioeconómica ............................................................. 257

La transformación social de la comunidad haitiana de Miami...... 260

La expansión del espacio residencial haitiano................................... 264

Conclusión ....................................................................................... 267

Referencias ...................................................................................... 269

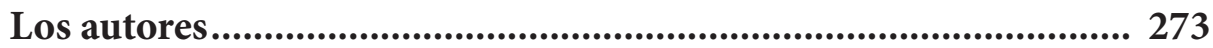


En recuerdo de Alejandro García, quien no pudo escribir en este libro 



\section{Introducción}

Las migraciones de los antillanos como fuerza laboral para trabajar en diversos segmentos económicos y áreas de Estados Unidos y el Caribe hispano, ya sea insular o continental, ha sido tratada por varios autores de manera general. En un libro de compendio editado en 1985 por Manuel Moreno Fraginals, Frank Moya Pons y Stanley L. Engerman, con el apoyo de la John Hopkins University, se muestra cómo la migración negra de antillanos anglófonos desde diversas fenomenologías sociales, económicas y culturales fue una constante, inclusive como aspecto "laboral" desde los tiempos de la esclavitud en las Antillas hispanas, principalmente, para la segunda mitad del siglo XIX.

Por su parte, Rosemary Brana-Shute y Rosemarijn Hoefte (1983) dan a conocer el famoso trabajo A Bibliography of Caribbean Migration and Caribbean Immigrant Communities, en donde, tal como lo dice el título, evidencian la bibliografía de lo que existía hasta ese entonces sobre la migración en el Caribe y de las características de las diferentes comunidades de inmigrantes. Bajo perspectivas similares, Annette Insanally, Mark Clifford y Sean SheriIf (2006), con los auspicios de Regional Footprints, publican The Travels and Travails of Early Caribbean Migrants, libro que sirve de radiografía para conocer el entramado social, económico y cultural que tienen las migraciones laborales en el espacio Caribe. Su contribución fue fundamental para el desarrollo de los tejidos productivos en los que estuvieron inmersos, llámense cultivos de caña de azúcar, tabaco, café o banano, o en obras de infraestructura como trenes, industria petrolera o el mismo canal de Panamá, 
pese a las reticencias de los aspectos raciales o los relacionados con las clases sociales. Además, su presencia contribuyó a la construcción colectiva de la sociedad en los lugares a donde llegaron. George Read Andrews (1997) plantea algo similar del trabajo negro y su exportación entre 1880 y 1930, pero para otras regiones de América Latina (p. 15). Circunstancias que, igualmente, Lara Putnam (2013) materializa en forma clara con su definición de movimientos radicales y políticas de raza a partir de los migrantes caribeños.

En cuanto al mundo hispano, Colin Clark publica el libro Caribbean Social Relations en 1978. Allí, el capítulo de Elizabeth Thomas Hope trata de la migración laboral intercaribeña desde las Antillas británicas como un fenómeno tradicional que se da después de los movimientos emancipatorios del Caribe hispano. Aspectos estos que Cadence Wynter (2001) hace ver claramente para el caso de Cuba entre 1885 y 1930. Igualmente, Philippe Bourgeois (1989) lo estudia en los países centroamericanos o Repúblicas Bananeras, deteniéndose en los asuntos raciales y la división del trabajo de las migraciones a los cultivos de banano. Casos similares a este, pero de manera específica para Costa Rica, constituyen, los estudios, primeramente, de Aviva Chomsky (1996) sobre la United Fruit Company entre 1870-1940, y, después, el de Lara Putnam (2002) acerca de The Company They Kept entre 1870 y 1960. Desde el punto de vista de las minorías étnicas, los temas de clase y aspectos raciales que representaron estas migraciones como fuerza laboral, también para Costa Rica, los aborda Ronald Harpelle (2001). Bajo esta misma premisa y zona geográfica, también trabaja Trevor Purcell (1993), pero lo hace sobre otros aspectos culturales. Por otro lado, Euraque (1996) reinterpreta el concepto de Banana Republics, especialmente para el caso de Honduras entre 1870-1972. Euraque pone en entredicho la construcción del Estado-nación y enfatiza que en estos procesos se dan las bases de una nueva configuración regional.

Un estudio pionero sobre la entrada y salida de jamaicanos al mundo del banano y a otros trabajos de plantaciones en el Caribe es el de George Robert (1957), quien hace un recuento detallado de la población de Jamaica y sus vaivenes, fruto del flujo migratorio permanente, en el que muestra estadísticas concretas para ciertos casos. Posteriormente, Gisela Eisner (1961) pone en evidencia, desde un análisis económico del 
Migraciones antillanas: trabajo, desigualdad y xenofobia

periodo 1830-1930, por qué la gente de esta isla antillana migra a otras partes a buscar trabajo. Para ello, toma como base los indicadores de marginalidad y pobreza en que estaba sometida esa colonia de Inglaterra. Otro trabajo que ilustra la migración laboral desde Jamaica y enfatiza la labor negra y el capital blanco es el publicado por Elizabeth McLean Petras (1988), que analiza esta problemática socioeconómica desde 1850 hasta 1930.

Las migraciones de trinitarios y tobaguenses hacia el resto de las islas del Caribe y de la América continental, en especial para Venezuela -en las construcciones de infraestructura vial y ferroviaria, así como de la industria petrolera-, y, en menor medida, para los países centroamericanos y Colombia en el asunto bananero, las ha estudiado en profundidad Kelvin Sing (1994). Para el caso de los oriundos de Saint Kitts y Nevis, Bonham C. Richardson (1983, pp. 16-28) publicó un artículo acerca de cómo fue el desarrollo de la isla, cómo vivían y sobrevivían los habitantes y cómo ello originó las migraciones a otros puntos del Caribe. Este mismo autor plantea algunos aspectos similares en otro trabajo, pero bajo casuísticas propias de Barbados, analizando el proceso migratorio hacia el canal de Panamá y el capital circulante e inversiones que se hicieron allí debido a la mano de obra inmigrante en este país, primero colombiano y después como república independiente. Bonham Richardson (1985) hace la serie de tiempo para 1900-1920 y tiene en cuenta que Panamá fue territorio de Colombia hasta 1903.

Otro autor que trabaja sobre la labor de afrodescendientes en el canal de Panamá y el ferrocarril, para ese entonces provincia de la Nueva Granada, es Velma Newton (1984), quien desde una perspectiva muy amplia hace un análisis de esta fenomenología desde 1850 hasta 1914, o sea, en el período de la construcción del Canal, incluso desde la época en que la obra era francesa - por la concesión que tenía contratada ese país con Colombia-, y termina con la puesta en marcha de las esclusas a cargo de los estadounidenses. Otra publicación sobre la labor negra de antillanos de la West Indies en esta infraestructura interoceánica es la de Michael L. Conniff (1985), en un proceso que abarca de 1904 a 1981. También está el trabajo de Olive Senior (2014), que concentra todo su esfuerzo investigativo en dar a conocer la trashumancia hacia procesos laborales de gente negra y procedente de las Antillas británicas a las obras del canal de Panamá. 
El libro Migraciones antillanas: trabajo, desigualdad y xenofobia recoge estudios de casos de la diáspora de trabajadores antillanos, de Haití y de las Antillas británicas, en el Gran Caribe en los siglos XIX y XX. Todos los trabajos recuerdan la correlación entre crecimiento económico e inmigración. Dentro de este esquema se analiza el desarrollo de las industrias azucarera, bananera, del cacao o del café desde la década de 1880, lo que produjo la necesidad de importar abundante mano de obra. Ello se tradujo en la entrada de inmigrantes, estacionarios o definitivos, que fueron contratados con salarios más bajos. Así mismo, la construcción del canal de Panamá, de carreteras o de vías férreas requirió una gran masa de fuerza laboral que procedió de países marcados por un estancamiento económico, bajos salarios, escasez de recursos o de tierras, altos precios de productos de primera necesidad, desempleo, superpoblación y crisis políticas. Estos factores presentes en distintos momentos en Haití y en las Antillas británicas provocaron desde mediados del siglo XIX la diáspora antillana, que comenzó a desplazarse por distintos países donde se crearon comunidades diaspóricas y transnacionales. República Dominicana, Panamá, Cuba, Costa Rica, Honduras, Colombia y Estados Unidos fueron varios de los países que contrataron esta fuerza laboral cuyo trabajo fue fundamental para la expansión de sus economías. Además del análisis de la relación entre el crecimiento económico y la fuerza laboral, los textos que integran el libro penetran en las dinámicas raciales de las sociedades postesclavistas, en la relación entre clase y raza, algunos de ellos entre clase, raza y género, y en el examen de la construcción de discursos identitarios y xenófobos en los que estos trabajadores fueron identificados con distintos nombres: yumecas en Colombia, cocolos en República Dominicana, tórtolos en Puerto Rico o negros de habla inglesa en Honduras.

La llegada de inmigrantes antillanos a Cuba es abordada por Oscar Zanetti Lecuona y Consuelo Naranjo Orovio. Oscar Zanetti, en "Los braceros jamaicanos en la industria azucarera cubana: el caso de la United Fruit Company", analiza el crecimiento de la producción azucarera en Cuba entre 1903 y 1925, que lo vincula a la llegada de braceros inmigrantes, cuyo trabajo fue clave para impulsar el crecimiento de la economía. Su estudio se centra en la expansión azucarera llevada a cabo por las compañías norteamericanas tras la adquisición de tierras en la parte oriental y la construcción de grandes centrales azucareras. Para realizar el 
Migraciones antillanas: trabajo, desigualdad y xenofobia

trabajo, la United Fruit Company — primero centrada en las plantaciones bananeras y luego en el azúcar - requirió contratar anualmente braceros procedentes, fundamentalmente de Haití y de Jamaica, aunque también llegaron de otras Antillas británicas. Para la entrada de estos inmigrantes, fue preciso la connivencia entre el Gobierno y los azucareros, que ajustó las leyes a sus demandas.

Por su parte, Consuelo Naranjo Orovio, en "Inmigrantes antillanos en Cuba: discursos económicos, raciales e identitarios, 1910-1940", analiza la llegada de inmigrantes y su relación con la construcción de discursos identitarios y raciales y el diseño de políticas migratorias, que fueron variando en función del crecimiento de la producción azucarera y de las presiones de los sectores azucareros. La respuesta ante la presencia de los braceros antillanos fue muy distinta. El grupo integrado por intelectuales, científicos y académicos consideró que la contratación de estos braceros era un factor que retrasaría e incluso perjudicaría la integración nacional, además de debilitar la soberanía nacional. Para ellos, la entrada de esta fuerza laboral aumentaría la diversidad racial, lo cual suponía una amenaza para el "porvenir de la nación" homogénea sobre la que la élite blanca descansaba la identidad nacional. El otro grupo lo encabezó el sector azucarero, que defendió la entrada de los trabajadores antillanos para mantener e incrementar la producción azucarera. El ataque a la inmigración de antillanos contuvo distintos elementos de tipo social, cultural, higiénico-sanitario y económico. Algunos médicos aportaron al debate sus ideas sobre el carácter antisanitario de esta migración y el peligro que suponía para la población del país. Algunos juristas subrayaron la necesidad de limitar su entrada y controlarla como hacían otros países del continente americano, otros les incriminaron señalándoles como criminales y delincuentes, mientras que algunas asociaciones y gremios laborales lanzaron campañas en su contra por considerar que rebajaban los salarios y restaban oportunidades laborales al cubano. Su entrada en Cuba se mantuvo desde la década de 1910 hasta crisis económica de los años treinta, momento en que el país cerró las puertas a la inmigración y comenzó su repatriación.

Estos debates en los que con frecuencia se equiparó la cultura con la etnia, o lo que en esos momentos llamaban "raza", y en los que el inmigrante, el extranjero, era considerado un peligro para la cultura y un 
"enemigo de la nación" son también abordados en otros capítulos del libro por Jorge Enrique Elías-Caro, Diana Senior Angulo, Yesenia Martínez García y Reina Rosario.

El legado sociocultural de las poblaciones inmigrantes en el Caribe colombiano procedentes de Jamaica, Trinidad y Tobago, Barbados, Santa Lucía y Granada es examinado por Jorge Enrique Elías-Caro en el capítulo titulado "Yumecas". West Indies workers en el enclave bananero de la United Fruit Company en el Magdalena (Caribe colombiano), 19001940". En él repasa el proceso migratorio de miles de personas afrodescendientes, conocidos como "yumecas", procedentes de las Antillas británicas para trabajar en el enclave bananero de la United Fruit Company en el Magdalena y su economía integrada entre 1900 y 1940. El estudio examina los flujos migratorios, su procedencia, además de las zonas de residencia y las relaciones entre los trabajadores inmigrantes destinados al sector bananero con las dinámicas propias del departamento del Magdalena; en especial, analiza los factores sociales, culturales y económicos.

Diana Senior Angulo, en su texto titulado "En sintonía con los tiempos: perfil ocupacional y división sexual del trabajo de la población afrocaribeña en Costa Rica durante la primera mitad del siglo XX" examina la segmentación del contingente laboral que se establece inicialmente en la provincia de Limón, entre finales del siglo XIX, y durante la primera mitad del siglo XX. Realiza la investigación desde la perspectiva de la división sexual del trabajo, la cual formó parte de la oferta laboral ofrecida y asumida por mujeres y hombres afrocaribeños. El análisis de los censos de población le ayudan a profundizar en términos de la división sexual del trabajo.

Yesenia Martínez García, en su trabajo "El Caribe hondureño y su negritud ¿una amenaza para los obreros o un peligro para la Nación?”, acomete el estudio de la población antillana trabajadora, llamada población negra de habla inglesa, en el contexto de la economía de plantación en el Caribe hondureño durante las primeras tres décadas del siglo XX. La élite política, los intelectuales y las organizaciones obreras criticaron en la prensa la presencia de esta fuerza laboral a la que se referían como "el problema negro". Como en otros países, las diferencias étnicas se usaron para denostar a esta población que no daba la imagen "positiva" que debía tener una nación moderna. Para ello, la autora analiza los discursos, 
Migraciones antillanas: trabajo, desigualdad y xenofobia

mecanismos legales o manifestaciones de rechazo de parte del Estado, intelectuales, obreros y medios de comunicación como la prensa, en el marco de la construcción de la imagen de la nación moderna y homogénea.

El capítulo de Reina Rosario, "Migraciones caribeñas de las colonias inglesas hacia Costa Rica y República Dominicana: procesos raciales y el impacto de las ideas de Garvey (1872-1950)", invita a pensar la racialización a que fueron sometidos los migrantes antillanos negros que llegaron a Costa Rica y República Dominicana a finales del siglo XIX y el impacto de las ideas de Marcus Garvey sobre ellos. Como en otros países del área, el inicio de esta migración obedeció a causas económicas y a la penetración de capital norteamericano en los enclaves bananeros y centrales azucareras. La movilidad y el cambio fueron características de estas migraciones. En el caso de República Dominicana en los años veinte del siglo XX, los antillanos británicos fueron remplazados por haitianos. En Costa Rica, en la década de 1930, los migrantes se trasladaron del Caribe al Pacífico, donde las leyes impedían la contratación de afrodescendientes, con lo que se les sometía a segregación territorial. La autora muestra cómo en estos dos países los inmigrantes lograron mantener y redefinir su identidad basándose en logias y sociedades de ayuda mutua, así como en el trípode familia-Iglesia-escuela. En ambos, su legado cultural forma parte de la cultura nacional, especialmente en la música y el baile.

La contribución de los trabajadores antillanos a la construcción del canal de Panamá es abordada por Juan Santiago Correa Restrepo en "Infraestructura ferroviaria y migración en Panamá, siglos XIX y XX”. Tras un balance historiográfico sobre las migraciones antillanas, el autor pasa a tratar la contratación de trabajadores en Panamá. Las condiciones difíciles del trabajo, por el clima, la higiene y el propio trabajo, fueron uno de los principales problemas que tuvo que resolver la compañía para reclutar personal. Durante el tiempo de la obra, se contrataron entre seis mil y siete mil personas, la mayoría de ellas provenientes de Jamaica o del departamento de Bolívar, en Colombia, así como martiniqueños, chinos, alemanes, portugueses, irlandeses, indios y austriacos, como consecuencia de las dos grandes obras de infraestructura iniciadas a mediados del siglo XIX: el ferrocarril y el canal. El determinismo geográfico en las teorías sobre las diferentes capacidades de adaptación y de trabajo de los 
Migraciones antillanas: trabajo, desigualdad y xenofobia

pueblos estuvo presente en la política de contratación que, según las fuentes, prefirieron trabajadores negros y mulatos al pensar que estaban mejor adaptados a las condiciones de la zona, por lo que soportarían más los rigores del clima y el trabajo.

La diáspora antillana continúa en la actualidad. Miles de personas se trasladan por América y Europa buscando un destino mejor. La comunidad diaspórica haitiana en Miami se afirmó como un importante polo de inmigración para los haitianos y la primera concentración de migrantes haitianos en EE. UU durante la segunda mitad del siglo XX. En este país, las comunidades haitianas más importantes se localizaban especialmente en Miami, Nueva York, Nueva Jersey y Boston. De eso se trata el capítulo que da cierre a este libro, "Los haitianos de Miami: ¿una comunidad en vías de integración?", de Cédric Audebert. Este analiza los fundamentos históricos y sociales de la estructuración comunitaria de esta población y su dinámica geográfica en la ciudad capital del estado de Florida. Según demuestra el autor, el perfil demográfico, cultural y socioeconómico de la población migrante haitiana permite comprender su organización y su inserción en el espacio de Miami, así como las traducciones espaciales de la dinámica demográfica y social de esta comunidad desde hace más de cuarenta años.

\section{Referencias}

Andrews, G. (1997). Black Workers in the Export Years: Latin America, 18801930. International Labor and Working Class History, (51), 7-29.

Brana-Shute, R. y Hoefte, R. (1983). A Bibliography of Caribbean Migration and Caribbean Immigrant Communities. Gainesville: University of Florida Press.

Bourgeois, Ph. (1989). Ethnicity at Work: Divided Labor on a Central American Banana Plantation. Baltimore: John Hopkins University Press.

Conniff, M. (1985). Black Labor on a White Canal: Panama, 1904-1981. Pittsburgh: University of Pittsburgh Press.

Chomsky, A. (1996). West Indian Workers and The United Fruit Company in Costa Rica, 1870-1940. Baton Rouge: Louisiana State University Press.

Eisner, G. (1961). Jamaica, 1830-1930: A Study in Economic Growth. Westport: Conn Greenwood Press.

Euraque, D. (1996). Reinterpreting the Banana Republic: Region and State in Honduras, 1870-1972. Chapel Hill, NC: University of North Carolina Press. 
Migraciones antillanas: trabajo, desigualdad y xenofobia

Harpelle, R. (2001). The West Indians of Costa Rica: Race, Class and the Integration of an Ethnic Minority. Montreal and Kingston: McGill-Queens University Press.

Insanally, A.; Clifford, M., y Sheriff, S. (2006). (Eds.). Regional Footprints: The Travels and Travails of Early Caribbean Migrants. Kingston: UWI Latin American Caribbean Centre.

McLean, E. (1988). Jamaican Labour Migration: White Capital and Black Labour, 1850-1930. Boulder y Londres: Westview Press.

Moreno, M.; Moya, F., y Engerman, S. (Eds.). (1995). Between Slavery and Free Labor: The Spanish Speaking Caribbean in the Nineteenth Century. Baltimore: John Hopkins Press.

Newton. V. (1984). The Silver Men: West Indian Labour Migration to Panama, 1850-1914. Mona: Institute of Social and Economic Research, UWI.

Purcell, T. (1993). Banana Fallout. Class, Color, and Culture Among West Idnians in Costa Rica. Los Angeles: Centre for Afro-American Studies, University of California.

Putnam, L. (2002). The Company They Kept: Migrants and the Politics of Gender in Caribbean Costa Rica, 1870-1960. Chapel Hill y Londres: The University of North Carolina Press.

Putnam, L. (2013). Radical Moves: Caribbean Migrants and the Politics of Race. Chapel Hill: University of North Carolina Press.

Richardson, B. (1983). Caribbean Migrants: Environment and Human Survival on St. Kitts and Nevis. Knoxville: University of Tennessee Press.

Richardson, B. (1985). Panama Money in Barbados, 1900-1920. Knoxville: University of Tennessee Press.

Roberts, G. (1957). The Population of Jamaica. Cambridge: Cambridge University Press.

Senior, O. (2014). Dying to Better Themselves. West Indians and the Building of the Panama Canal. Chapel Hill: University of North Carolina Press.

Singh, K. (1994). Race and class Struggles in a Colonial State: Trinidad, 19171945. Kingston: The Press University of the West Indies; University of Calgary Press.

Thomas-Hope, E. (1978). The Establishment of Migration Tradition: British West Indian Movements to the Hispanic Caribbean after Emancipation. En C. Clarke (Ed.), Caribbean Social Relations (pp. 66-81). Liverpool: Center for Latin American Studies.

Wynter, C. (2021). Jamaican Labor Migration to Cuba, 1885-1930 in the Caribbean Context (Tesis de doctorado). Chicago, Illinois: University of Illinois at Chicago. 



\title{
Los braceros jamaicanos en la industria azucarera cubana: el caso de la United Fruit Company ${ }^{1}$
}

\author{
Oscar Zanetti Lecuona \\ Academia de la Historia de Cuba
}

En poco más de veinte años (1903-1925), la producción azucarera de Cuba se quintuplicó, llegando a sobrepasar cinco millones de toneladas. Semejante progresión productiva en un país que había sufrido los embates de una cruenta guerra, cuya población apenas totalizaba 1,6 millones de habitantes al comenzar el siglo $\mathrm{XX}$, hubiese resultado imposible sin un cuantioso aporte migratorio. Formando contingentes anuales que llegarían a decenas de miles de individuos, ya fuese como empleados estacionales o inmigrantes definitivos, los trabajadores extranjeros constituyeron una fuerza de trabajo decisiva para impulsar el crecimiento de la economía. Fuente principal de aquel torrente humano fue España, la antigua metrópoli, pero, a efectos de la expansión azucarera, la contribución fundamental la hicieron braceros procedentes de tierras más cercanas: del vecino Haití, de Jamaica y de otras posesiones británicas en el archipiélago antillano.

1. Este trabajo es parte del proyecto "Connected Worlds: The Caribbean, Origin of Modern World". This project has received funding from the European Union's Horizon 2020 research and innovation programme under the Marie Sklodowska Curie grant agreement núm. 823846. Professor Consuelo Naranjo Orovio, Instituto de HistoriaCSIC, directs this project. 
Los braceros jamaicanos en la industria azucarera cubana:

el caso de la United Fruit Company

\section{La United Fruit Company en el oriente cubano}

El formidable incremento que experimenta la producción azucarera cubana durante las primeras décadas del siglo XX tuvo su escenario mayor en las provincias del este del país, un territorio que había quedado al margen de la expansión de la plantación esclavista en la centuria anterior. En 1901, las entonces provincias de Camagüey y Oriente apenas elaboraban 13\% de las 650.000 toneladas de azúcar producidas ese año; un cuarto de siglo después, su participación alcanzaría casi $60 \%$ de una zafra ocho veces mayor. Los agentes fundamentales de tan vertiginoso crecimiento fueron compañías norteamericanas, las que, valiéndose del control político y económico adquirido por Estados Unidos en Cuba, comenzaron a apropiarse de tierras en las regiones orientales y fomentaron colosales fábricas de azúcar. Una de las pioneras en ese movimiento inversionista fue la United Fruit Company, cuyas operaciones se iniciaron en 1899. Resultado de la fusión —en el propio año 1899- de la Boston Fruit Company y las firmas de Minor C. Keith, empresario norteamericano con fuertes inversiones ferroviarias y bananeras en Centroamérica, la United Fruit tuvo desde su origen algunos intereses en Cuba, producto de las actividades de la Boston Fruit, que, además de poseer plantaciones de banano en Jamaica, llevaba años comerciando con fruta de origen cubano en Estados Unidos. En correspondencia con ese perfil, el objetivo primario de la nueva empresa en Cuba no fue el azúcar, sino la producción bananera.

En las décadas finales del siglo XIX, el banano en Cuba era un floreciente negocio que desde la zona de Baracoa había extendido su cultivo hacia el oeste, a lo largo de la costa norte oriental. La más reciente de esas plantaciones se había fomentado en los alrededores de la bahía de Banes, debido a la iniciativa de la familia Dumois, que en 1887 adquirió o arrendó más de 20.000 hectáreas en tierras banenses, las cuales se propuso explotar mediante tres firmas: la Banes Fruit Company, la Samá Fruit Co. y la Dumois Fruit Company, esta última destinada a la comercialización. En 1895, las empresas de Dumois aportaron casi un tercio de los 6,8 millones de racimos de banano cubano exportados al mercado norteamericano, pero esa producción se desplomaría al año siguiente, tras el inicio de la guerra de Independencia. Los hermanos Dumois marcharon entonces a EE. UU., donde Hipólito — que actuaba como cabeza de familia- 
vendió parte de las acciones de sus empresas a la Boston Fruit. De modo que, al constituirse la United Fruit, ya tenía en cartera valores cubanos en cuantía cercana al millón y medio de dólares, activos engrosados con un nuevo aporte de los Dumois, que se incorporaron como accionistas minoritarios a la nueva compañía.

Las primeras gestiones de la United Fruit en Cuba estuvieron encaminadas a rehabilitar las plantaciones bananeras. Designado administrador de la empresa en Banes, Hipólito Dumois conjugó dicha actividad con la adquisición de nuevos terrenos para la compañía en las vecinas haciendas de Mulas y Tacajó. Aunque la producción y exportación de banano mostraba renovado vigor, muy pronto se hizo evidente que el desarrollo de ese renglón no constituiría el objetivo primordial de la compañía, cuyo presidente, Andrew Preston, se había percatado de que la producción azucarera podría reportarle mayores beneficios. Con la reorientación del negocio hacia el azúcar, las tierras adquiridas se dedicaron en su mayor parte a la siembra de caña, para cuyo procesamiento comenzó a montarse una fábrica en cayo Macabí, al borde de la bahía de Banes, que contaría con facilidades portuarias para la exportación directa del dulce producto. El central Boston —como se denominó a la nueva industria- realizó su primera zafra en 1901, campaña que, por las necesidades de ajuste de la maquinaria y cierta inexperiencia organizativa, distó de resultar un éxito. Sin embargo, al año siguiente, con la instalación de un nuevo molino, el Boston produjo casi 20.000 toneladas de azúcar, ubicándose entre los mayores centrales de la isla. La opción azucarera de la United Fruit, además de implicar cambios en el personal administrativo y técnico del negocio, generó también una mayor demanda de recursos, particularmente en lo relativo a materia prima y fuerza de trabajo (García Álvarez, 2008, pp. 103-108).

Para satisfacer las necesidades inmediatas y potenciales de caña de azúcar, la United desató un voraz proceso de apropiación de terrenos, facilitado por el hecho de que casi todas las tierras en la zona de Banes se hallaban bajo el impreciso régimen de propiedad de las llamadas haciendas comuneras. En tal sentido, la Orden Militar 62 dictada por el Gobierno interventor norteamericano constituyó un útil instrumento legal, pues, bajo sus provisiones y contando con los servicios de habilidosos abogados, la compañía pudo promover el deslinde de dichas haciendas y apropiarse 
de terrenos bastante más extensos que los que realmente había adquirido. Como resultado de esas prácticas, al cabo de una década (1913), la United Fruit figuraba como propietaria de unas 37.000 hectáreas de tierras banenses. Hipólito Dumois, eficaz agente en dicho proceso, brindó otro extraordinario servicio a la compañía, al gestionar la compra a bajo precio de los Terrenos de Nipe, extenso latifundio de más de 60.000 hectáreas, cuya adquisición propició el avance de la United hacia la zona de Mayarí.

Un acaparamiento de tierras de tal envergadura pudo llevarse a cabo con notable rapidez porque la compañía se había asentado en territorios de escasa población. La región que se extendía a lo largo de la costa norte oriental tenía muy baja densidad demográfica; en la zona de Banes, apenas nueve habitantes por $\mathrm{km}^{2}$, y en la de Mayarí, aún menos: 5,5, cifras ambas bien por debajo del promedio nacional de 14,18 habitantes por $\mathrm{km}^{2}$ en 1899. Si dicho cuadro poblacional operaba en favor del control de la región por parte de la United Fruit, la pobreza en recursos humanos podía convertirse en una amenaza para el desarrollo de sus actividades. En un primer momento, cuando estas todavía no alcanzaban particular intensidad, la demanda de fuerza de trabajo pudo satisfacerse a partir de trabajadores locales - sobre todo en Banes-, cuyas filas la propia compañía contribuyó a incrementar con los campesinos despojados de sus tierras por el deslinde de las haciendas comuneras. A ello debe añadirse el natural atractivo que sobre los pobladores de otras provincias y algunos inmigrantes hubo de ejercer el desbroce y cultivo de tierras en un país cuya economía emergía de la guerra. Pero, para el crecimiento perspectivo de los negocios, la escasez de mano de obra se perfilaba como un serio problema.

\section{Expansión azucarera y fuerza de trabajo}

A partir de 1905, la situación laboral de la United Fruit comenzó a complicarse. A las inversiones destinadas a duplicar la capacidad productiva del central Boston, se sumaban los requerimientos de mano de obra de la Samá Fruit y, sobre todo, el fomento de un nuevo central, el Preston, que entraría en producción en 1907 con una capacidad de molida que demandaba el cultivo - y la posterior cosecha- de extensas plantaciones cañeras en los Terrenos de Nipe. Debe, además, tenerse en cuenta que, a 60 kilómetros al oeste de Banes, otra compañía norteamericana, 
la Cuban American Sugar, había puesto en explotación un gran ingenio, el Chaparra, mientras que la conclusión del ferrocarril central entre Santa Clara y Santiago de Cuba, por la también norteamericana Cuba Company en 1902, había abierto a la explotación inmensos espacios prácticamente vírgenes en las provincias de Camagüey y Oriente. Esa misma compañía ferroviaria estaba tendiendo un ramal hacia la bahía de Nipe, y en un punto de su litoral cercano a Banes construía los muelles y almacenes de lo que sería el puerto de Antilla, que aspiraba a convertirse en uno de los mayores exportadores del país.

Ante la manifiesta escasez de mano de obra - Boston había enfrentado un serio déficit de trabajadores en la zafra de 1904- el gerente de la United Fruit en Banes, Harold Harty, solicitó a Manuel Silveira, representante de la compañía en La Habana, que gestionase con el presidente de la República, Tomás Estrada Palma, permisos para contratar personal en el extranjero; en particular, para traer y asentar en sus propiedades a 300 labradores de Islas Canarias, cuya contratación estaría a cargo de Elders \& Fyffes, una firma bananera asociada que operaba en dicho archipiélago (Zanetti y García, 1976, p. 209).

La gestión de la United enfrentaba un difícil obstáculo legal. Casi a punto de terminar su mandato en Cuba, el 15 de mayo de 1902, el Gobierno interventor norteamericano había dictado la Orden Militar 155, que declaraba ilegal la introducción e inmigración de extranjeros mediante contrato o convenio con el propósito de emplearles en trabajos u ocupaciones de cualquier clase. Concebida para allanar el camino a la firma de un Tratado de Reciprocidad Comercial con la futura República de Cuba, dicha prohibición ofrecía garantías a los productores remolacheros estadounidenses contra una potencial competencia del azúcar cubano elaborado con trabajo barato. En medio de la escasez de mano de obra, esa regulación migratoria actuaba como un freno al crecimiento de la producción azucarera, de modo que compañías y hacendados, tanto individualmente como mediante gestiones de la Liga Agraria que los representaba, procuraron del Gobierno cubano una normativa más laxa que facilitase la introducción de trabajadores. Dichas demandas fructificaron en la ley de Inmigración y Colonización promulgada en julio de 1906, la cual propiciaba, bajo ciertas condiciones, la inmigración de familias, así como de braceros destinados a faenas agrícolas procedentes de Europa y de Canarias. La nueva 
legislación involucraba al Estado como promotor de la inmigración y no solo permitía, sino que alentaba la contratación de los inmigrantes por parte de compañías y terratenientes, quienes podrían introducirlos a través de determinados puertos de la isla una vez obtenida la autorización gubernamental (Pichardo, 1969, t. 2 pp. 199-201 y 273-276).

En 1905, cuando aún se tramitaba la ley migratoria, la United Fruit obtuvo permiso para introducir 300 trabajadores de Canarias, 100 de ellos con sus familias, a los que asentó en dos caseríos construidos al efecto, medida en la que se perfilaba un plan de colonización destinado a asegurar a la empresa un mínimo de fuerza de trabajo. Sin embargo, esa estrategia laboral cambió al aprobarse al año siguiente la ley de inmigración, pues la puesta en vigor de dicha normativa abrió la posibilidad de obtener mano de obra de manera temporal contratando los braceros en los momentos y en la cuantía que se les necesitase, fórmula ideal para una industria de tipo estacional como la azucarera. Así, junto a los jornaleros españoles que la compañía había venido reclutando mediante contratistas, se hizo notar la presencia de braceros procedentes de Jamaica.

El empleo de trabajadores jamaicanos fue una posibilidad que los ejecutivos de la United habían contemplado desde muy temprano, pues como la compañía explotaba plantaciones bananeras en Puerto Antonio y otras localidades de la isla vecina, su contratación podía resultar relativamente sencilla. En la medida en que las ordenanzas migratorias abrieron espacio para ello, la UFCo. parece haber realizado de manera más o menos encubierta algunas de esas operaciones, pero sus agentes sobre todo se dedicaron a contratar jamaicanos, que con frecuencia arribaban como inmigrantes ilegales a la costa sur de la provincia de Oriente. Tanto en Banes como en el central Preston -cuyas zafras a partir de 1909 superaron 40.000 toneladas-, el empleo de macheteros jamaicanos se hizo notar $y$, aunque en su mayoría estos se contrataban sobre bases estacionales para hacer la zafra, algunos terminaron por radicarse en la zona. En 1911, un censo efectuado por la United Fruit en su División Banes registraba un total de 1.187 residentes extranjeros, en su gran mayoría (915) españoles, pero entre los cuales aparecían en segundo lugar 138 súbditos británicos, casi todos ellos jamaicanos (Sintes, Abreu y Bellido, 2013, p. 43).

Las diversas fórmulas migratorias arbitradas, aunque significaron un respiro para la compañía, no constituían una garantía en cuanto a la 
disponibilidad de fuerza de trabajo. Sobre todo, porque la producción azucarera en la provincia oriental continuaba aumentando aceleradamente, y con ella, la competencia entre empresas para agenciarse trabajadores. La zafra de 1913, que en Oriente superó medio millón de toneladas, según los estimados requirió 15.000 trabajadores más que la cosecha realizada en esa provincia tres años antes. De no conseguirse una oferta adecuada, la ascendente demanda de fuerza de trabajo impulsaría una tendencia al aumento del salario que los distintos empleadores deseaban evitar.

En 1910, la puesta en vigor del decreto que reglamentaba la aplicación de la ley de Inmigración y Colonización despejó el camino para una solución de largo alcance, pues permitía a personas jurídicas y naturales la introducción de "colonos inmigrantes". A tenor de ese reglamento, en 1913, la Nipe Bay Company — subsidiaria de la United Fruit que operaba el central Preston - obtuvo, mediante decreto presidencial de José Miguel Gómez, el primer permiso concedido por el Estado cubano para traer a sus plantaciones cañeras un millar de braceros antillanos. Antes de que concluyera ese propio año, el nuevo presidente de la República, Mario García Menocal, dictaba otro decreto autorizando la libre entrada al país de los trabajadores de las obras del canal de Panamá — muchos de ellos jamaicanos-que estaban a punto de concluir.

Aunque gracias a la reiteración de los permisos presidenciales desde 1914 hasta 1917 ingresaron en Cuba un promedio de 10.000 braceros antillanos por año, en el mismo lapso entraron en actividad 25 nuevos centrales azucareros - nueve de ellos en la provincia de Oriente- y la producción del dulce aumentó en 600.000 toneladas, manteniéndose en ascenso la demanda de mano de obra. Al concluir la zafra de 1915, el jefe del departamento de Agricultura de la United en Banes advertía al administrador Harty que la próxima zafra debía empezar temprano para asegurarse trabajadores, pues la tardanza en iniciar la cosecha recién concluida había provocado que algún personal se marchase a laborar a los centrales vecinos. Como los permisos para introducir braceros al parecer no satisfacían plenamente la demanda, la compañía había movilizado sus agentes para reclutar esos trabajadores en localidades del sur de la provincia - principalmente en Guantánamo-, por donde entraban al país muchos inmigrantes ilegales. Dicho tráfico motivó una encendida campaña de prensa contra la entrada de los braceros antillanos, en la cual se 
Los braceros jamaicanos en la industria azucarera cubana:

el caso de la United Fruit Company

entremezclaban sentimientos racistas con los intereses de algunos hacendados cubanos de las provincias occidentales, quienes consideraban que el empleo de esos trabajadores baratos otorgaba una ventaja injustificada a las compañías azucareras norteamericanas. Estas, sin embargo, movieron sus influencias en Washington y aprovecharon la entrada de Estados Unidos (y de Cuba) en la Primera Guerra Mundial para conseguir que el presidente Menocal solicitase al Congreso la redacción de una ley autorizando la libre entrada de braceros antillanos al país hasta dos años después del cese de las hostilidades, la cual fue promulgada en agosto de 1917 (Chailloux, 2015, pp. 44-47).

Gracias a la nueva disposición, de un ingreso de 19.701 braceros inmigrantes registrados en 1918 se saltó a 34.231 al año siguiente, llegándose a un tope de 63.190 en 1920, cuando las cotizaciones del azúcar superaron momentáneamente 20 centavos de dólar por libra. El repentino desplome del precio hasta menos de 4 centavos antes de que terminase ese año y la oleada de quiebras que lo acompañó pusieron un freno a la introducción de trabajadores contratados, que descendió hasta un mínimo de 5.864 en $1922 .^{2}$ La Gran Guerra, por otra parte, había terminado en noviembre de 1918, y de acuerdo con lo estipulado por la vigente ley migratoria de 1917, la importación ilimitada de braceros debía finalizar. Aunque se apeló al subterfugio de que Cuba aún no había firmado la paz con Hungría para mantener libres los ingresos en 1921, el manifiesto cambio en la coyuntura azucarera imponía una revisión. No solo el precio del dulce se situaba a un nivel relativamente bajo, sino que, como resultado de ello, en Estados Unidos tomaba fuerza una tendencia proteccionista impulsada por los intereses remolacheros que intentaba poner término al crecimiento de las exportaciones cubanas. De concretarse una limitación de la producción en Cuba, el cese de la inmigración de braceros haría recaer la mayor parte de esa eventual disminución productiva

2. Aunque el registro migratorio cubano durante las tres primeras décadas del siglo XX era bastante exacto, la estadística de ese movimiento presenta serios problemas debido a las categorías empleadas. Solo se clasificaban como "inmigrantes" aquellos que arribaban al país carentes de recursos; quienes al ingresar podían presentar una cantidad - relativamente pequeña - de dinero eran registrados como "pasajeros". Obviamente, entre estos últimos, un buen número llegaba con la intención de trabajar y radicarse en Cuba, pero no se les consideraba inmigrantes. Aunque, en el caso de los antillanos, la gran mayoría debe haber carecido de recursos, la situación apuntada puede haber afectado en alguna medida su registro. Pérez de la Riva (1979) hace un estimado del movimiento migratorio sobre la base de un modelo confeccionado que aquí seguimos (pp. 32-35). 
en los grandes centrales norteamericanos del este del país, posibilidad a la que apostaron los hacendados cubanos desatando una feroz campaña contra la inmigración de antillanos (Zanetti, 2006, pp. 38-43).

Los intereses de las compañías azucareras norteamericanas en Cuba eran lo suficientemente poderosos para imponerse en aquel larvado enfrentamiento, pero si bien la inmigración antillana hubo de mantenerse, ahora habría de realizarse sobre nuevas bases. Después de un primer decreto dictado en junio de 1921, que disponía el reembarque de los braceros introducidos a partir de 1917 - el cual tuvo un cumplimiento muy parcial—, se retornó al régimen de autorizaciones para la introducción de trabajadores contratados en 1923, permisos otorgados en determinadas cuantías a las compañías que lo solicitasen; al recibir la autorización, estas asumían el compromiso de repatriar a los trabajadores una vez finalizadas sus ccontratos. Amparadas por las autorizaciones, las entradas de braceros continuaron efectuándose con cuantías anuales que oscilaban entre 20.000 y 30.000 individuos, hasta que las evidencias de una crisis profunda y dilatada en 1929 determinaron el cierre definitivo de ese deplorable tráfico humano.

Los vaivenes legislativos ocasionaron altibajos en la inmigración, pero en ningún momento la interrumpieron. De 1907 a 1930, ingresaron en Cuba unos 315.000 inmigrantes antillanos, a los cuales debería añadirse una gran cantidad de individuos — bastante superior a 100.000 - que al entrar fueron registrados como "pasajeros", que eran inmigrantes en su gran mayoría, pero cuya cantidad efectiva es imposible precisar. La cifra registrada de "inmigrantes" comprendía dos corrientes principales: los haitianos, de los que se contabilizaron 183.983 entradas, y los jamaicanos, que totalizaban 120.972; a este último contingente se suman a los efectos prácticos un poco más de 8.000 inmigrantes procedentes de las Antillas menores, en su gran mayoría súbditos británicos a quienes se les englobaba bajo la denominación genérica de "jamaiquinos". Hasta 1916, los inmigrantes jamaicanos fueron los más numerosos, pero a partir de la liberalización del tráfico de braceros y hasta la finalización del ciclo inmigratorio, resultaron superados por los haitianos, excepto en el año 1919. ${ }^{3}$

3. Cálculos efectuados a partir de Pérez de la Riva. La cantidad de jamaicanos seguramente era superior, pues al ingresar algunos podían acreditar los recursos monetarios necesarios para ser clasificados como "pasajeros" (1979, tablas VI y VII). 
Si bien el principal motor de tan nutrida corriente migratoria era la demanda de fuerza de trabajo en las plantaciones de Cuba, esta se vio igualmente favorecida por las circunstancias socioeconómicas en que la mayor parte de las islas antillanas arribaron al siglo XX, las cuales impulsaban a emigrar a muchos de sus pobladores. Tras sufrir las devastaciones derivadas de un cruento proceso independentista, la economía haitiana se vio aplastada por el compromiso de pago de una elevada indemnización a Francia, su antigua metrópoli. En la nueva república, la tierra había sido acaparada en su mayor parte por la oficialidad militar y figuras políticas; los exesclavos, frustradas sus aspiraciones de acceso a la tierra, provocaron sucesivas revueltas campesinas, factor que, junto al extendido empleo de la aparcería, propició la atomización de la estructura agraria, con el predominio de minifundios cada vez menos capaces de satisfacer las necesidades de las crecientes familias haitianas. Al producirse la ocupación militar de Haití por Estados Unidos en 1916, esa situación se había tornado crítica, de modo que las autoridades norteamericanas encontraron en la emigración de trabajadores - tanto hacia Cuba como a la vecina República Dominicana - una oportuna válvula de escape (Castor, 1978, pp. 54-56).

En Jamaica, los esclavos liberados por la abolición en 1833 abandonaron masivamente las plantaciones, lo cual ocasionó el desplome de la producción azucarera en la isla. Para proveerse de fuerza de trabajo, los propietarios apelaron a la inmigración contratada de unos 40.000 braceros de India, los cuales propulsaron una dinámica demográfica que ya venía acelerándose sobre bases naturales. Al finalizar el siglo XIX, con una densidad que superaba 60 habitantes por $\mathrm{km}^{2}$, la población de Jamaica excedía la oferta de empleo de su economía, situación que se agravó a inicios del XX por los efectos de dos huracanes que devastaron las plantaciones de la isla. La tendencia migratoria que ya había conducido a miles de jamaicanos hacia las obras del canal de Panamá y a las plantaciones bananeras en Centroamérica cobró entonces mayor impulsó, alimentando dos cuantiosas corrientes de emigrantes, una dirigida a Estados Unidos y la otra a Cuba. 


\section{Los braceros antillanos y la United Fruit}

El peculiar sistema adoptado por la United Fruit para desarrollar su negocio azucarero hizo que esa compañía figurase entre las que empleaban un mayor número de braceros. A diferencia de empresas como la Cuban American o la West Indies, que fomentaron la mayor parte de sus cañaverales mediante el arriendo de tierras a colonos - agricultores que, en virtud de tal contrato, quedaban obligados a abastecer de caña a sus centrales-, la United, quizá por la experiencia acumulada en las plantaciones bananeras, asumió directamente la producción de $90 \%$ de la materia prima procesada en sus dos ingenios. Además de garantizar el suministro de caña, esa práctica a menudo fue fuente de ganancias adicionales, pero exigía disponer de recursos para desbrozar y preparar las tierras, sembrarlas, cultivarlas y, finalmente, cosecharlas, exigencia especialmente rigurosa en materia de fuerza de trabajo.

La circunstancia apuntada permite comprender por qué la United siempre figuró entre los más activos promotores de medidas que facilitasen la introducción de braceros contratados. Los diversos medios empleados por la compañía durante sus primeros años en Cuba para asegurar la permanencia de los trabajadores inmigrantes explica la extraordinaria dinámica demográfica de los municipios de Banes y Mayarí. Apenas en dos décadas estos triplicaron sus poblaciones; en el primer caso, creciendo de 7.336 habitantes en 1899 a 26.694 en 1919, y Mayarí de 8.504 a 28.793 durante el mismo lapso. Después de la introducción de antillanos autorizada en 1913, la compañía parece haber satisfecho puntualmente sus necesidades adicionales de mano de obra mediante la contratación de inmigrantes que entraban por vías ilegales, a juzgar por el frecuente envío de sus reclutadores a Guantánamo, principal mercado de braceros en la región oriental. Sin embargo, tras la aprobación de la ley de 1917 que liberalizó la entrada de obreros extranjeros, hay evidencias de que la empresa comenzó a contratar sus braceros en Haití y Jamaica, los cuales hacía desembarcar por las instalaciones portuarias de sus centrales en Banes y Nipe (Zanetti y García, 1976, pp. 215-216).

La cantidad de braceros introducidos por la United Fruit durante la etapa de "libre importación" (1918-1921) resulta difícil de establecer, pues solo se encuentran datos parciales; pero ese movimiento se hace 
Los braceros jamaicanos en la industria azucarera cubana:

el caso de la United Fruit Company

más claro y bien determinado a partir de 1923, tras restablecerse el sistema de autorizaciones.

Cuadro 1. Braceros introducidos por la United Fruit y proporción que representan dentro del total de inmigrantes antillanos en Cuba (1923-1929)

\begin{tabular}{|c|c|c|c|c|}
\hline Año & $\begin{array}{c}\text { Braceros } \\
\text { autorizados }\end{array}$ & $\begin{array}{c}\text { Ingresos } \\
\text { efectivos }\end{array}$ & $\begin{array}{c}\text { Total de } \\
\text { inmigrantes } \\
\text { antillanos }\end{array}$ & $\begin{array}{c}\text { \% de ingresos } \\
\text { respecto } \\
\text { al total }\end{array}$ \\
\hline 1923 & 4000 & 3904 & 16932 & 23,0 \\
\hline 1924 & 5000 & 4783 & 27278 & 17,5 \\
\hline 1925 & 6200 & 5976 & 23481 & 25,4 \\
\hline 1926 & 9500 & 8621 & 15740 & 23,9 \\
\hline 1927 & 10500 & 9619 & 17219 & 57,7 \\
\hline 1928 & 10500 & 9600 & 15327 & 62,6 \\
\hline 1929 & 9600 & n. d. & 4582 & - \\
\hline
\end{tabular}

Fuente: Calculado a partir de Zanetti y García (1976, cuadro 20) y Álvarez Estévez (1988, tablas VI y VII).

Como puede apreciarse, las necesidades de fuerza de trabajo de la United Fruit fueron en aumento, a pesar de que la demanda de braceros antillanos por otras compañías decreció a partir de 1925 en consonancia con la evolución de la producción azucarera cubana, que tras alcanzar un récord en ese año tendió a disminuir hacia finales de la década, salvo un breve repunte en 1929. Tal contraste se explica porque en esos años los dos centrales de la compañía continuaron ampliando sus capacidades, de modo que entre 1923 y 1928 sus producciones se incrementaron aproximadamente en $30 \%$.

La contratación de braceros por la United Fruit muestra tendencias semejantes a las que ya se apuntaron a escala nacional. La compañía promovió inicialmente la contratación de jamaicanos, más versátiles como trabajadores y que se comunicaban en el mismo idioma que los funcionarios norteamericanos. Esos y otros factores influyeron sin duda en su asentamiento. En 1916, la División Banes registraba 1.376 jamaicanos residiendo en sus propiedades, incluyendo cierto número de mujeres 
y niños, lo cual representaba un aumento de más de un millar respecto a los súbditos británicos censados cinco años antes. La presencia jamaicana parece haber continuado siendo mayoritaria hasta 1920, pero al reimplantarse el régimen de autorizaciones en 1923, resultó más expedita la introducción de haitianos, que además demostraban ser especialmente eficaces en el corte de caña, tarea que entonces demandaba el mayor número de brazos.

A partir de 1917, cuando la inmigración de braceros se tornó masiva, la United Fruit utilizó dos modalidades de contratación. La primera, más frecuente durante la fase de entradas libres entre 1917 y 1922, descansaba en contratistas privados con quienes la compañía acordaba un pago global de acuerdo con el número de trabajadores enganchados. Dichos contratistas se encargaban de reclutar los braceros en su país de origen, así como de trasladarlos hasta un puerto previamente determinado, aunque el traslado marítimo podía también correr a cuenta de la United, que para dicha operación disponía de los buques de su Flota Blanca. En la segunda modalidad, los trabajadores eran contratados - principalmente en Haití- por agentes de la compañía, que se hacían cargo de su traslado a Cuba. Esta variante se había practicado desde temprano, pero quedó como procedimiento único a partir de 1923, al entrar en vigor el régimen de autorizaciones que exigía la repatriación de los braceros. La contratación de mano de obra inmigrante era de tanta importancia para la United Fruit y su trasiego revestía tal complejidad que sus divisiones cubanas contaron con empleados de cierta jerarquía especializados en esas operaciones, como fue el caso de Antonio Urbina, cubano nacido en Haití, encargado de la contratación de braceros para la División Preston, quien además fungía como cónsul haitiano en Preston y llegó a tener vivienda asignada en el exclusivo barrio de ese central, reservado a los funcionarios norteamericanos (Álvarez Estévez y Guzmán, 2012, p. 139).

En torno al tráfico de braceros se articulaba toda una red de intereses. En el caso haitiano, los contratistas reclutadores debían disponer de una licencia y ajustar su operación al reglamento establecido por las autoridades interventoras norteamericanas en el país, mientras que el servicio consular de Haití recibía 18 dólares por los trámites de salida (pasaporte, visa consular, etc.) de cada bracero emigrante. Respecto a los jamaicanos, la United tuvo inicialmente la ventaja de operar desde antaño en Jamaica, lo 
cual facilitó la contratación de algunos contingentes. Sin embargo, cuando la entrada de braceros se liberalizó en 1917, la mayoría de los jamaicanos comenzó a llegar a Cuba por propia iniciativa. Más instruidos que los haitianos, los braceros jamaicanos - entre los cuales eran muy contados los analfabetos - se informaban sobre las oportunidades y condiciones de empleo en Cuba por los periódicos de su país, como el Gleaner y The Daily Gleaner, en cuyas páginas de anuncios abundaban, además, las ofertas de pasaje de compañía navieras que hicieron del trasiego de braceros un espléndido negocio. El pasaje resultaba relativamente barato -entre 8 y 10 dólares - y, en los casos en que el potencial emigrante no dispusiese de esa cantidad, siempre había negociantes - como Antonio Alomá, representante del central Santa Lucía - que podían adelantar dicha suma y comprometer el trabajo del bracero con una compañía determinada (Chailloux, 2015, pp. 91-100). En los casos (al parecer más numerosos) en que el bracero llegaba a Cuba por cuenta propia, la contratación la realizaban agentes de la United en Santiago de Cuba, Guantánamo u otros pequeños embarcaderos de la costa sur de Oriente. No faltaron entre los jamaicanos braceros con experiencia de trabajo en Cuba que no solo pagaban su pasaje, sino que se contrataban personalmente en las oficinas de la compañía, para prescindir de intermediarios cuyos "servicios" iban siempre en detrimento de los ingresos del trabajador.

Por lo regular, los braceros llegaban a las instalaciones de la empresa en contingentes más o menos numerosos. Concentrados en el patio de ferrocarriles del central, se les inscribía y asignaba un número que serviría para su identificación. Desde ahí se procedía a distribuirlos por colonias y plantaciones de acuerdo con las necesidades de brazos de la cosecha cañera, alojándolos en barracones construidos en las cercanías del transbordador, donde la caña se pesaba y era trasbordada a los vagones del ferrocarril que la transportaba hasta los molinos del central. Cada uno de esos grupos o cuadrillas era puesto bajo la autoridad de un nuevo contratista, salvo que el contrato inicial estipulase que el mismo contratista que se había ocupado del enganche de los braceros se encargaría también de dirigirlos y supervisar su trabajo en los campos. Cualquiera que fuese la fórmula acordada, entre la compañía y el trabajador mediaba siempre un contratista encargado de manejar la mano de obra, supervisar las labores y pagar los salarios (Zanetti y García, 1976, pp. 238-246). 


\section{Régimen laboral y condiciones de vida}

Los antillanos venían a Cuba a cortar caña; solo en muy contados casos pudieron iniciar su trayectoria laboral en otras tareas. Ocasionalmente se encontraba trabajo en el desmonte y preparación de terrenos, pero esa faena solía reservarse a cuadrillas de jornaleros españoles. Si algún bracero lograba permanecer en tierras de la compañía azucarera durante el tiempo muerto, quizá pudiera emplearse en la siembra o el cultivo de caña; mas al exigirse la repatriación en la década de 1920, esa posibilidad quedó prácticamente anulada. Durante la zafra, la jornada habitual se extendía de sol a sol y no era raro que ya caída la noche se continuase alzando la caña cortada a las carretas. El bracero en ocasiones acompañaba al carretero - casi siempre cubano- hasta la pesa, pues del pesaje de la caña dependía su salario, aunque esa función, por lo general, estaba en manos del contratista, que a partir de dicha operación ajustaba los pagos de sus trabajadores. El monto del salario pagado a los braceros ha sido asunto muy controvertido. Noticias de prensa y otros testimonios de la época aseguran que el salario recibido por los antillanos era muy inferior -incluso menos de la mitad- del pagado a cubanos y españoles. Sin embargo, los investigadores que han tenido oportunidad de revisar las nóminas y otra información salarial, no solo en la documentación de la United Fruit, sino en la de la Cuban American Sugar, la Manatí Sugar y otras compañías que empleaban braceros, han encontrado escasas evidencias de una diferencia sustancial en los salarios abonados. La importación de braceros, más que provocar un "envilecimiento del salario" al incrementar la oferta de mano de obra, impidió que este aumentase en las regiones centro-orientales, donde escaseaba la fuerza de trabajo; su efecto sobre los salarios fue más bien estabilizador, manteniéndolos dentro de un rango similar al que prevalecía en los ingenios del occidente del país (Zanetti y García, 1976, p. 246; McGillivray, 2009, p. 114).

No obstante, las condiciones en que el bracero realizaba su trabajo hacían que el salario devengado resultase en la práctica bastante inferior al estipulado, particularmente en el caso de los haitianos, que, desconocedores del idioma y en su gran mayoría analfabetos, eran víctimas fáciles de todo tipo de patrañas. La compañía usualmente pagaba al contratista sobre la base del volumen de caña que semanalmente su cuadrilla había 
pesado en el trasbordador, quedando al arbitrio de este los pagos individuales a los braceros de acuerdo con las tareas por ellos realizadas. Resulta ocioso advertir que dichos pagos rara vez se correspondían con la cantidad de caña efectivamente cosechada; al bracero se le hacía muy difícil controlar el pesaje de las cañas que había cortado, a menudo desconocía la norma de pago establecida o simplemente era incapaz de calcular la suma de dinero que totalizaba su trabajo en la semana.

La retribución salarial era solo un segmento de la vasta red de explotación en que se hallaba atrapado el trabajador antillano. Este comenzaba por adeudar el pasaje al contratista o a la compañía - y después de 1922, el costo de su repatriación-, a lo cual se sumaba el pago por el alojamiento, aun cuando se tratase de un inmundo barracón. Por más que minimizase sus necesidades, el bracero se veía obligado a consumir productos a los precios fijados en la red de tiendas de la compañía, que eran, por lo regular, los únicos establecimientos comerciales a su alcance. De acuerdo con lo que estipulase el contrato, podía hacérsele un descuento para atención médica, que en ciertos momentos fue gratuita, aunque cabe advertir que en ese rubro la United Fruit cumplía a cabalidad sus obligaciones, no por particular filantropía, sino porque a los inmigrantes antillanos solían acusarles de ser trasmisores potenciales de enfermedades infecciosas, de modo que el servicio de salud y las campañas contra enfermedades trasmisibles como la malaria permitían desmontar dicho argumento. A esto debe añadirse que el bracero, dada su condición de extranjero, con frecuencia tenía que sufrir los desmanes de la Guardia Rural y otras autoridades cubanas.

El panorama trazado en los párrafos anteriores describe con exactitud el fatal destino del bracero haitiano; sin embargo, a los jamaicanos y otros antillanos "ingleses" podía tocarles mejor suerte. Tratándose de súbditos británicos, los trabajadores de las West Indies disponían de un servicio consular comprometido con sus derechos, por más que a veces los hiciesen valer a regañadientes. Por su parte, los jamaicanos y demás angloantillanos parecen haber sido bastante celosos en sus reivindicaciones, hasta el punto en que un diplomático británico estimaba que, a comienzos de los años 20,90\% del trabajo cotidiano de su Consulado en Santiago de Cuba consistía en asuntos promovidos por esos inmigrantes (Giovannetti-Torres, 2018). 
A diferencia de sus homólogos haitianos, que casi en su totalidad eran analfabetos, 93\% de los jamaicanos entrados en Cuba sabían leer y escribir y estaban familiarizados con las relaciones monetario-mercantiles. Aunque, al igual que los haitianos, la mayoría de los jamaicanos se registraban como jornaleros o labradores a su llegada, una proporción significativa de los inmigrantes anglófonos - casi 10\%- declaraba poseer algún oficio. Los factores apuntados y el hecho de hablar el mismo idioma que sus empleadores otorgaron una ventaja a los jamaicanos, no solo con relación a los haitianos, sino también respecto a muchos campesinos cubanos. No era raro, por tanto, que un jamaicano consiguiese trabajar como obrero calificado en el central o en el ferrocarril, se desempeñara como albañil, jardinero, sirviente, chofer y hasta guardajurado, llegando incluso a ser mayoría y hasta copar algunas áreas de trabajo, como sucedía con las labores de estiba en Cayo Juan Claro, embarcadero de la Cuban American en Puerto Padre. Aunque desproporcionada, como suele ocurrir en todo contingente migratorio, la composición por sexos de la inmigración jamaicana registraba una mayor presencia femenina, promediando de 4 a 5 hombres por mujer, frente a una razón de 10 a 20 entre los haitianos. Las jamaicanas supieron abrirse paso y eran muy apreciadas como cocineras y en otros desempeños del servicio doméstico, al igual que como costureras, bordadoras y modistas. Constituidos en familias, los angloantillanos tenían mayor presencia en núcleos urbanos, ya fuese en bateyes de ingenio o poblaciones cercanas (Chailloux, 2002, p. 56).

A pesar de sus mejores condiciones, los inmigrantes jamaicanos no conseguían escapar a ese elemento fundamental en la triste situación del bracero: el aislamiento. Este tenía una base física, pues los lugares de alojamiento de los trabajadores se hallaban determinados por la compañía, de manera que, aun en núcleos urbanos y caseríos, el antillano se veía condenado a un hábitat segregado. A las distancias físicas se sumaban las culturales; no solo las barreras idiomáticas, sino las diferencias en costumbres y modo de vida que ciertos intereses económicos, al igual que la prensa y algunos políticos que a ellos respondían, manipulaban para alimentar los prejuicios de la población cubana. Tales manejos en ocasiones tenían un hálito científico, como bien lo ilustra la conferencia pronunciada en 1923 por el Dr. Jorge Le Roy en la Academia de Ciencias Médicas, Físicas y Naturales, donde el eminente epidemiólogo acusaba a los 
inmigrantes antillanos de "[...] haber introducido enfermedades que habíamos borrado de nuestros cuadros nosológicos [...]", así como de la "[...] intromisión en nuestras costumbres de vicios y delitos que caen de lleno dentro de las mallas del Código Penal [...]". En este último "perjuicio" insistía Heraldo de Cuba (1922, 17 de diciembre) Cuba, un periódico de circulación nacional, cuando aseguraba: "En la provincia de Oriente, en Cuba, los haitianos se dedican a la brujería, contaminando a los morenos cubanos con atávico salto atrás [...]”, mientras que El Pueblo (1923, 28 de enero), diario de Banes, se hacía eco del sentir del comercio local lamentando que con cada bracero se perdiese un cliente potencial: "Esa plaga de jamaiquinos que arriban a nuestras playas al principio de todas las zafras y se retiran después de terminadas las mismas, cuando a fuerza de ahorro y privaciones voluntarias han logrado reunir respetables cantidades monetarias, es indiscutible que daña grandemente al país". La repulsa al antillano - y, en particular, al haitiano - era llevada hasta el paroxismo con la acusación de que en sus prácticas religiosas realizaban sacrificios rituales de niños blancos (Le Roy Cassá, 1929, p. 5).

Las actitudes adversas a los trabajadores antillanos se exacerbaban en las coyunturas críticas, pues a la xenofobia, el racismo y otros prejuicios se sumaban el temor a los despidos y el desempleo. Así ocurrió en 1921, cuando en medio de la crisis generada por la caída del precio del azúcar se desencadenó la violenta campaña contra la contratación de braceros que ya hemos mencionado. Temeroso de que la recesión económica pudiese derivar en un serio conflicto social, el Gobierno ordenó el retorno a sus países de origen de todos los braceros introducidos durante los años de libre contratación que se hallasen ociosos, seguido por otra disposición en la cual se aseguraba que el Estado cubano asumiría el costo de dicha operación. A tal efecto se contrató a varias compañías navieras, pero en algunos casos estas actuaron con lentitud y en otros asumieron una conducta fraudulenta, debido a lo cual en Santiago de Cuba llegaron a concentrarse más de 12.000 antillanos a la espera de ser embarcados, situación que, en menor cuantía, se repitió en otros puertos orientales. Finalmente, fueron repatriados varios contingentes, cuyo transporte en algunos casos asumieron compañías azucareras, entre las cuales no parece haber figurado la United Fruit. El proceso de repatriación distó de consumarse, pero antes de finalizar 1921, otro decreto presidencial que 
insistía en su ejecución dispuso que la autorización para importar trabajadores se otorgase solo a las empresas comprometidas a repatriarlos.

Lejos de lo que podría suponerse - y en ocasiones se ha afirmado-, la repatriación no entrañaba un perjuicio para las compañías que habitualmente empleaban braceros; por el contrario, hay evidencias de que estas solían cumplir con satisfacción el compromiso de reembarcarlos. La conducta de la United Fruit al respecto es bien elocuente.

Cuadro 2. United Fruit Company: braceros antillanos introducidos y repatriados 1924-1928.

\begin{tabular}{|c|c|c|}
\hline Año & Braceros ingresados & Braceros repatriados \\
\hline 1.924 & 4.783 & 5.160 \\
\hline 1.925 & 5.976 & 6.435 \\
\hline 1.926 & 8.621 & 8.848 \\
\hline 1.927 & 9.619 & 10.496 \\
\hline 1.928 & 9.606 & 9.813 \\
\hline
\end{tabular}

Fuente: Zanetti y García Álvarez (1976, cuadro 20).

Salta a la vista que las cifras de repatriaciones resultaban siempre algo superiores al número de braceros importados cada año. No hay por qué dudar de la exactitud de estos datos, pues proceden de los informes legales internos que anualmente elaboraban las divisiones cubanas de la compañía, ni tampoco la diferencia a favor de los reembarques puede atribuirse a que la compañía introdujese inmigrantes ilegales, ya que las autorizaciones gubernamentales satisfacían plenamente las solicitudes de las empresas y podían aumentarse con facilidad. Una explicación bastante razonable de las diferencias entre salidas y entradas es que estas ocurrían porque la United, junto con los braceros introducidos anualmente, repatriaba cierta cantidad de antillanos ingresados con anterioridad que habían permanecido en las propiedades de la compañía. Esa mano de obra, dadas las facilidades otorgadas por el Gobierno cubano para importar trabajadores, ya no resultaba necesaria y podía constituir una fuente de problemas al permanecer ociosa durante el tiempo muerto. Documentos procedentes de los archivos de la Cuban American Sugar Company, cuyos centrales Chaparra y Delicias eran los otros grandes 
Los braceros jamaicanos en la industria azucarera cubana:

el caso de la United Fruit Company

"importadores" de braceros en la región nororiental, ponen en evidencia un interés similar por repatriarlos, conducta que no puede atribuirse a la sola preocupación por recuperar la fianza de 20 pesos por inmigrante que las compañías debían depositar como garantía de su repatriación.

En realidad, la inmigración estacional era el recurso perfecto para las compañías azucareras norteamericanas, pues solo tenían que mantener a los braceros durante el tiempo de zafra cuando estos permanecían ocupados. Y como el aumento de la productividad fue reduciendo progresivamente la duración de la cosecha, devolver al trabajador innecesario a su país resultaba una genuina solución. De no haber existido esa posibilidad, las compañías habrían tenido que buscarles una ocupación remunerativa, correr el riesgo de que estos escapasen a otras zonas en busca de trabajo o asumir el peligro, aún mayor, de mantener un foco de descontento y agitación dentro de sus propiedades. El movimiento laboral de los antillanos en los años 20 se configuró por tanto como una "inmigración golondrina”. Una encuesta realizada por la United Fruit entre los braceros en 1927 lo atestigua:

Cuadro 3. United Fruit Company: viajes realizados por los braceros contratados, 1927

\begin{tabular}{|c|c|}
\hline Viajes anteriores & Número de hombres \\
\hline Ninguno & 2.777 \\
\hline Uno & 3.633 \\
\hline Dos & 2.744 \\
\hline Tres & 1.237 \\
\hline Cuatro & 367 \\
\hline Cinco & 140 \\
\hline Seis & 48 \\
\hline Siete & 34 \\
\hline Ocho & 12 \\
\hline Nueve & 5 \\
\hline Diez & 3 \\
\hline
\end{tabular}

Fuente: Zanetti y García Álvarez (1976, cuadro 21) 
El análisis de los datos demuestra que el 75\% de los antillanos que trabajaban para la United en ese año habían estado antes en Cuba, en su mayoría en más de una ocasión.

A finales de la década de 1920, sin embargo, la fórmula mágica de la inmigración estacional daba visibles muestras de agotamiento. La sobreproducción mundial de azúcar, las restricciones de las zafras decretadas a partir de 1926 por el Gobierno cubano para enfrentar la caída del precio del dulce, así como la política arancelaria norteamericana indicaban con toda claridad que la producción azucarera en Cuba no solo había dejado de crecer, sino que sus perspectivas futuras apuntaban a un declive. La coyuntura depresiva dio nuevo impulso a las corrientes de opinión contrarias a la contratación de antillanos, tanto en los medios obreros, para los que la inmigración constituía una seria amenaza ante la tendencia declinante en la oferta de empleo, como en otros sectores de la sociedad movidos por intereses económicos y sentimientos racistas. La decisión de reservar a los cubanos la mitad de los empleos creados por el plan de obras públicas ideado por el gobierno de Gerardo Machado para contrarrestar los efectos recesivos la restricción de las zafras era un claro indicio de que el Estado actuaría a favor de sus nacionales. Y para corroborarlo, la dictadura de Machado comenzó a deportar inmigrantes antillanos, para lo cual requirió - y obtuvo- la cooperación de varios Gobiernos (Carr, 1998, p. 104).

Consciente de que la importación de braceros estaba tocando a su fin, en 1928 la United Fruit puso en marcha un "plan de colonización" para asentar familias cubanas en sus tierras, a las cuales se dotaría de vivienda y una pequeña parcela de autoconsumo. A comienzos de 1929, en la División Preston, esas viviendas, distribuidas en varios caseríos, alojaban un total de 632 familias, con lo cual se garantizaba la disponibilidad de unos 1.400 trabajadores. Aunque en su gran mayoría se trataba de jornaleros cubanos o españoles, 71 de esas familias estaban constituidas total o parcialmente por jamaicanos y haitianos que también fueron asentados como mano de obra. En Banes se siguió una política similar, de modo que, en la zafra de 1931, esa división empleó 921 antillanos, lo cual representaba el $27 \%$ del total de macheteros que trabajaron durante esa cosecha. Cabe destacar que entre esos trabajadores ya no figuraba ningún bracero importado, pues, aunque la United fue autorizada a traer 9.000 
antillanos en 1929, según las evidencias disponibles, dicha contratación no se hizo efectiva.

De acuerdo con el censo efectuado en 1931, se hallaban en Cuba algo más de 100.000 antillanos, de los cuales aproximadamente la mitad residían en la provincia de Oriente. Con un desempleo que en el momento más agudo de la crisis (1933) se estimó que afectaba a casi un tercio de la población activa del país, la presión ejercida sobre esos inmigrantes alcanzó su mayor intensidad. El Gobierno provisional revolucionario que asumió el poder en septiembre de 1933 promulgó en noviembre de ese año el decreto-ley de Nacionalización del Trabajo, el cual estipulaba que la mitad de los trabajadores de todas las empresas del país debían ser cubanos. En el mes anterior, ratificando la política iniciada por la depuesta dictadura de Machado, el gobierno provisional había dictado otro decreto (2332 de 1933) que disponía la repatriación forzosa de los extranjeros sin trabajo ni recursos. Aunque esa medida parecía destinada más bien a los inmigrantes españoles, el reglamento de la llamada "Ley del 50\%", dictado antes de finalizar ese año, se enfiló directamente hacia los braceros, sobre todo los haitianos, al declarar sujetos a deportación a todos los extranjeros que se encontrasen ilegalmente en el país. La medida debía ser aplicada con la cooperación del Ejército, participación esta última que dio lugar a numerosas escenas de violencia y diversas atrocidades, incluyendo la deportación de inmigrantes establecidos por muchos años en Cuba, donde habían llegado a constituir familias (Álvarez Estévez, 1988, pp. 213-257).

En julio de 1934, se calculaba que ya habían sido reembarcados 8.000 braceros, en su mayoría haitianos, según un informe rendido por Rogelio Pina, a quien el Gobierno había encomendado un estudio de esa cuestión. Pina reportaba que los representantes de las mayores compañías azucareras en Camagüey y Oriente alegaban que los antillanos a su servicio no estaban desempleados y, por tanto, no representaban una carga pública. En particular, la United Fruit consiguió evitar la repatriación de cierto número de braceros, en especial jamaicanos, asentados en sus propiedades, algunos de los cuales se acogieron a la posibilidad de obtener una carta de naturalización abierta por la ley constitucional promulgada en 1935. No obstante ese recurso, todavía al finalizar la década de 1930, se hacían deportaciones de antillanos; según lo informado por el administrador de Preston, en 1943 solo quedaban 595 de esos trabajadores 
asentados en el área de su división, circunstancia que le hacía temer que ocurriese un déficit de mano de obra al recuperarse la producción azucarera en la coyuntura de la Segunda Guerra Mundial.

\section{Jamaicanos en tierras de la United Fruit}

El empleo de braceros antillanos por las grandes compañías azucareras norteamericanas y, sobre todo, el asentamiento de algunos grupos de inmigrantes en territorios propiedad de esas empresas, ocasionaron un interesante proceso sociocultural cuyo impacto puede apreciarse aún en nuestros días. Obviamente, cuando dichos asentamientos dieron lugar al establecimiento de comunidades con una identidad propia en lugares determinados, esos fenómenos sociales y culturales se hicieron más perceptibles y han sido también perdurables.

En correspondencia con la demanda local de brazos para las plantaciones cañeras, en zonas como Ciego de Ávila, Esmeralda, Puerto Padre, Banes y Mayarí, entre otras, tuvieron lugar asentamientos de braceros jamaicanos, creándose comunidades cuyas denominaciones -Jamaica Town, Kingston, etc. - eran fiel testimonio de su origen. Al transcurrir el tiempo, un buen número de jamaicanos abandonaron por propia iniciativa las zonas de plantación para instalarse en ciudades como Guantánamo y Santiago de Cuba, así como en otros núcleos urbanos donde crearon sus clubes e instituciones; solo que, incorporados a la natural dinámica citadina, esos núcleos perdieron los rasgos característicos de las comunidades de braceros (Sánchez Guerra, 2004).

Entre los asentamientos de antillanos en tierras de la United Fruit, la comunidad más representativa fue, sin duda, La Güira, establecida prácticamente como un barrio jamaicano anexo al pueblo de Banes. En otros puntos del territorio ocupado por la compañía también se produjeron asentamientos, como ocurrió en el batey del central Preston, donde cierto número de jamaicanos se radicó en la barriada de Brooklyn, al igual que en Los Negros, Guaro y algunos otros caseríos enclavados en predios rurales de ambas divisiones de la United. Pero en esas localidades, los pobladores jamaicanos fueron pocos y su asentamiento resultó menos compacto, de modo que, al transcurrir el tiempo y entremezclarse con personas de otros orígenes, tendió a desdibujarse su identidad. 
El barrio de La Güira, también conocido como barrio Antillano o New Town, fue la ubicación fundamental dispuesta por la United para los braceros angloantillanos. Separada — como toda el área, urbana de la empresa- del pueblo de Banes por un riachuelo, La Güira también se hallaba convenientemente apartada, tanto del barrio Este (o americano), destinado a los funcionarios y empleados de mayor jerarquía, como de la pequeña barriada en que residían los trabajadores cubanos de los talleres y el ferrocarril. En las primeras décadas del siglo XX, la compañía urbanizó esa zona y fue construyendo allí viviendas de madera sobre pilotes con techo de zinc, dotadas de portal, sala, cocina, baño interior y una o dos habitaciones, así como algunos barracones con habitaciones individuales. Además de una infraestructura básica consistente en varias calles, agua corriente y electricidad, al transcurrir el tiempo, el barrio llegó a disponer de dos templos y una escuela, así como de una tienda mixta que era parte de la red comercial de la compañía. Todos esos inmuebles eran propiedad de la United Fruit; los trabajadores inmigrantes habitaban sus casas en condición de inquilinos - aunque la compañía no cobraba alquiler-, recurso que además de servir para arraigar la mano de obra, también aseguraba su mayor compromiso, pues, de ser despedido, el trabajador y su familia eran también expulsados de su vivienda.

A inicios de la década de 1930, ya finalizada la inmigración de braceros, las familias jamaicanas en La Güira totalizaban unos 400 individuos, a los cuales podían sumarse algunas decenas de integrantes de otras familias anglocaribeñas. La circunstancia de trabajar todos para un mismo patrono, ya que muchas mujeres eran empleadas en casas de la compañía, el idioma y las costumbres compartidas, así como la creación de instituciones que propiciaban el desarrollo de vínculos de solidaridad entre los habitantes de la barriada, hicieron de La Güira una comunidad relativamente cerrada, proclive, por tanto, a conservar y reproducir hábitos, pautas de conducta y otros importantes aspectos del modo de vida jamaicano (Pérez Nakao, 2019, pp. 42-48).

Evidencia mayor de esa suerte de exclusivismo comunitario era su marcada endogamia, ya que el $84,6 \%$ de las familias del barrio eran fruto de matrimonios entre jamaicanos. Esa tendencia se debilitaría al paso de los años, pues las segundas y terceras generaciones de inmigrantes, aunque conservasen el idioma de sus padres, hablaron el español como 
primera lengua, compartían sus estudios y sus labores con cubanos y en algunos casos terminaron desposándolos, con lo que aumentó la frecuencia de matrimonios mixtos. Sin embargo, aún en las familias fruto de esos enlaces, podía observarse la persistencia de costumbres, normas sociales y hábitos de origen jamaicano. La familia operó como un ámbito fundamental para la reproducción de significativos patrones culturales, ya se tratase del gusto por los platos cocinados en casa o el disfrute de los ritmos anglocaribeños, además de constituir el marco más apropiado para dar continuidad a pautas de conducta como la laboriosidad, el respeto a los mayores y el fervor religioso.

Más allá del marco familiar, la identidad jamaicana subsistió en diversas manifestaciones de sociabilidad. Los inmigrantes conservaron prácticas sociales que, cobijadas en las Iglesias, mutualidades, logias y otras formas asociativas, expresaron su voluntad de crear y sostener espacios para desarrollar las relaciones humanas y su espiritualidad. El primero de esos núcleos institucionales en la comunidad antillana banense fue de carácter religioso. Promovida por la Sociedad Misionera Bautista —muy influyente en Jamaica-, en 1917 se estableció una Iglesia de esa denominación cuyo templo fue construido por la United Fruit. Además de las ceremonias del culto y la escuela bíblica, el templo bautista era un importante centro de otras actividades sociales como las celebraciones navideñas y fue durante algunos años sede de una sociedad de socorro mutuo. En 1945 se fundó otra Iglesia, la Evangélica Pentecostal Monte Sinaí, que llegaría a contar con mayor feligresía.

Desde 1924 inició sus actividades en La Güira una sociedad que tres años después se inscribiría oficialmente bajo la denominación de Jamaica Club. Como su nombre indica, agrupaba principalmente a jamaicanos residentes en el barrio, aunque también participaron en ella algunos otros anglocaribeños. Se trataba de una institución de recreo, beneficencia e instrucción en la cual los inmigrantes y sus descendientes encontraron sostén frente a la marginación, sobre todo sus elementos más humildes y necesitados. Preocupado por preservar las costumbres jamaicanas, el club en sus fiestas reservaba un lugar prioritario a los bailes tradicionales, mientras que en cursos especialmente dedicados a la instrucción de señoritas se dedicaba espacio al arte culinario, especialmente para la elaboración de los platos típicos de Jamaica. 
Los braceros jamaicanos en la industria azucarera cubana:

el caso de la United Fruit Company

En marzo de 1921 fue recibido en Banes Marcus Garvey, prominente líder negro jamaicano que había fundado en su isla natal la Asociación Universal para el Progreso del Negro (UNIA, según su sigla en inglés), organización cuya sede principal se trasladó a Nueva York en 1916, al radicarse Garvey en dicha ciudad. La UNIA tenía como objetivo fundamental reafirmar la identidad y reavivar el orgullo negro, pues ante las condiciones de segregación y la discriminación de que esa raza era objeto en Estados Unidos y otras naciones, Garvey estimaba imposible que los negros pudieran integrarse en dichas sociedades. Mediante la educación, la promoción cultural, el activismo político y hasta ciertas iniciativas encaminadas a dotar a las comunidades negras de una base económica (la UNIA creó una empresa naviera, la Black Star), el movimiento gestado por Garvey, cuyo objetivo final era regresar a África para constituir allí una poderosa nación, llegó a tener millones de adeptos. A inicios de la década de 1920, Garvey decidió dar mayor alcance a su organización, para lo cual emprendió un viaje por países del Caribe, incluyendo algunos en los que se habían asentado colectivos de inmigrantes angloantillanos. Como parte de esa gira, el líder de la UNIA permaneció dos semanas en Cuba, visitando comunidades en Camagüey y Oriente, entre ellas Banes, donde fue recibido con grandes festejos en la iglesia bautista de la localidad. El viaje proselitista de Garvey a Cuba dio por resultado la fundación de varias divisiones de la UNIA en la isla, una de ellas, la número 52, en Banes, donde contaría con un local para actos y reuniones denominado Liberty Hall. Las actividades desplegadas por la UNIA contribuyeron a la concientización de los angloantillanos en Banes y otras localidades cubanas, movilizándolos para enfrentar las condiciones de explotación y la discriminación a las que se hallaban sometidos (Pérez Nakao, 2019, pp. 69-82). ${ }^{4}$

Negro World, el diario de la UNIA, publicaba cartas enviadas desde Cuba que denunciaban cómo las compañías y los hacendados azucareros se valían de los braceros para disminuir el salario de sus trabajadores, denuncia que también aparecía en la prensa cubana, solo que en las páginas

4. Desde la década de 1930 la UNIA experimentó una apreciable decadencia que profundizaría la muerte de Garvey en 1940. Sin embargo, su división banense -aunque muy menguada -sobrevivió hasta 1961, siendo probablemente el último vestigio de dicha organización en Cuba. 
de esta los acusados eran los braceros, convertidos en culpables de un sistema del cual eran meros instrumentos. A los criterios económicos que promovían el repudio a los antillanos dentro de los colectivos laborales, se sumaban los prejuicios raciales y hasta el nacionalismo, corriente que en la década de 1920 se afianzaba entre los sectores populares. Marginados dentro del proletariado, los antillanos se mostraban renuentes a participar en protestas, huelgas y otras manifestaciones obreras, en las cuales, de participar, corrían el riesgo de ser reprimidos con mayor dureza.

La heterogénea composición nacional de los colectivos de trabajadores constituía un serio obstáculo para la organización sindical en el sector azucarero, a lo cual se sumaba el extendido empleo del sistema de contratas que, sobre todo en el caso de los braceros, acentuaba su aislamiento, pues fraccionaba la imagen del patrono. Pese a todo ello, cuando a mediados de los años veinte se gesta en Cuba una organización sindical de alcance nacional —Confederación Nacional Obrera de Cuba (CNOC)—, en los congresos celebrados con tal propósito estuvieron representados algunos colectivos de obreros antillanos. Así ocurrió en el Segundo Congreso Obrero, celebrado en Cienfuegos en febrero de 1925, en el cual participó Enrique Shackleton como representante de la Unión de Obreros Antillanos de Santiago de Cuba, y nuevamente en el Tercer Congreso que tuvo lugar unos meses después en Camagüey. Las ponencias y documentos elaborados en ambos cónclaves incluyeron denuncias de las particulares condiciones de explotación que sufrían los obreros antillanos. En el propio año 1925, según algunos testimonios y otras evidencias, un buen número de braceros angloantillanos participaron en una huelga que afectó seriamente la zafra en el central Chaparra (Tellería, 1973, pp. 119, 142, 160 y 188; McGillivray, 2009, pp. 175-178).

En Banes, los distintos gremios de la localidad habían constituido en 1923 la Unión Obrera, organización territorial de inspiración anarco-sindicalista en la cual la colectividad proletaria del central Boston no estaba integrada como tal, aunque en ella participaban trabajadores de la United Fruit, principalmente del ferrocarril y los departamentos industriales. En 1925, al cesantear la compañía a una docena de obreros del central banense, se declaró una huelga en su enclave de Macabí que la Unión extendió a otros sectores laborales de la localidad, movimiento que fue suspendido poco después ante las pequeñas concesiones hechas 
por el administrador de la United y las presiones del alcalde de Banes. No existen, sin embargo, evidencias de que algunos trabajadores jamaicanos participasen en esta u otras acciones de la Unión Obrera, ni que dicha organización se refiriese a la particular situación de los braceros en alguno de sus pronunciamientos.

La progresiva - aunque parcial — integración de los antillanos a las movilizaciones obreras se produjo al calor de la grave crisis de los años 30. En esa circunstancia, el pequeño partido comunista cubano, que desde su creación, en 1925, había trabajado por la reorganización del movimiento sindical, decidió concentrar sus acciones en el sector azucarero y, a finales de 1932, promovió la creación del Sindicato Nacional de Obreros de la Industria Azucarera (SNOIA). La asamblea constitutiva, en la cual participaron delegados de una treintena de centrales, formuló sus demandas (jornada de 8 horas, aumentos salariales, proscripción del pago en vales, etc.) y caracterizó a la huelga como principal forma de lucha. Como parte de su estrategia, los comunistas también se propusieron incorporar a los braceros antillanos al movimiento obrero, recogiendo algunas de sus aspiraciones entre las demandas sindicales. Con la UNIA en franca decadencia, los antillanos se fueron sumando a la lucha sindical. Tras el derrocamiento de Machado en agosto de 1933 como resultado de una huelga general, el sindicato azucarero extendió sus bases organizativas hasta abarcar a la mayoría de los ingenios de la isla, incluidas las dos fábricas de la United Fruit. En medio de la situación revolucionaria, cuando más de una docena de centrales estaban tomados por sus trabajadores, se desató una huelga de los jornaleros agrícolas de la División Banes en demanda de mayores salarios, con la participación de algunos grupos de braceros, movimiento que no tardó en propagarse a la industria y otros departamentos. En Preston, donde también se había desatado la huelga, la situación de los funcionarios de la United se tornó igualmente comprometida. Con los centrales prácticamente bajo el control de los huelguistas, la compañía se vio obligada a aceptar sus principales demandas, a partir de lo cual la situación se mantuvo en un delicado equilibrio. En 1934, la instalación de un gobierno de derecha, apoyado en el Ejército comandado por el coronel Fulgencio Batista, dio lugar a una creciente oleada represiva que tuvo en Preston uno de sus más violentos escenarios. Fracasada una huelga general convocada en marzo de 1935, 
la represión terminaría por desarticular a la mayoría de los sindicatos del país, incluyendo los establecidos en las divisiones de la United (Carr, 1998, pp. 96-104; Zanetti y García Álvarez, 1976, pp. 254-278)

Las repatriaciones forzosas de antillanos dispuestas en los años treinta también afectaron a trabajadores de la United Fruit, aunque, según parece, bastante más a los haitianos que a los jamaicanos. No obstante, el registro de los trabajadores extranjeros dispuesto por la Ley de Nacionalización del Trabajo, así como las medidas favorables al empleo de nacionales e inmigrantes naturalizados, la proporción de jamaicanos que optaron por la ciudadanía cubana en los años treinta fue relativamente baja - cerca del 10\% en Banes-, probablemente debido a su confianza en la protección brindada por el servicio consular británico. La tendencia de los inmigrantes hacia la integración parece haber estado influida por su situación social, pues los jamaicanos de posición relativamente elevada se mostraron más propensos a asimilarse a la sociedad cubana, a juzgar por el ingreso de varios de ellos al club Flor Crombet, agrupación de la élite "de color" cubana en Banes, cuyas actividades evidenciaban las aspiraciones de clase media de sus miembros. Aunque el transcurso del tiempo y los matrimonios mixtos obraron a favor de la progresiva asimilación de los jamaicanos banenses a la sociedad cubana, el empeño de estos y de sus descendientes en preservar su herencia étnica ha dejado una impronta bien reconocible en la cultura regional (Pérez Nakao, 2019, pp. 55-51 y anexos 7 y 8).

Las expresiones de esa supervivencia se observan con mayor intensidad en Banes, pero también son perceptibles en la pequeña comunidad jamaicana del desaparecido central Preston, hoy denominada Guatemala. Si bien ya ninguno de los inmigrantes jamaicanos sobrevive, algo más de 450 de sus descendientes representan un núcleo importante de población en el antiguo barrio de La Güira. Todavía hoy, a pesar de la agitada dinámica existencial, muchos de ellos se sientan a la mesa en torno al cabeza de familia. Aunque no cada día, en ocasiones especiales continúan sirviéndose platos tradicionales jamaicanos como un congrí con los frijoles y el arroz cocidos en leche de coco, el especiado "rondón", en el cual el pescado también se cuece en leche de coco, o el "calalú", quimbombó con carne o pescado adobado en vinagre. Esa tradición culinaria ha incorporado a la flora local al "mapén", fruto del llamado "árbol de pan”, y el ackee o seso vegetal. Esos y otros platos ocupan un lugar privilegiado en 
Migraciones antillanas: trabajo, desigualdad y xenofobia

las fiestas de la comunidad, en las cuales aún se baila el "cuadril" — baile de figuras de remoto origen británico- y el may pole, danza en torno a un largo palo con cintas que son tomadas por cada bailador, quienes las van trenzando al ritmo del calypso o el reggae. La creación de un conjunto de danzas en el club Anglocaribeño, surgido en Banes en 1999, ha incorporado esos bailes al folklore local. Algunos descendientes jamaicanos son practicantes de la santería cubana, pero la mayoría conserva su religiosidad tradicional; para ellos el templo sigue siendo un punto focal de la vida en común, en el cual celebran sus fiestas siguiendo rituales establecidos desde antaño. También se conservan ciertas tradiciones funerarias; en Guatemala (Preston) se observa la novena noche (Ninth night), pues transcurridos nueve días del deceso, los familiares y amigos del difunto se reúnen para despedir con cánticos y rezos el alma del finado (Batista y Paz, 2011).

Un siglo después de haber llegado a su cenit la inmigración de braceros jamaicanos a Cuba, en la larga relación de apellidos que ellos incorporaron al listado de familias cubanas, hoy se encuentran médicos, periodistas, científicos, deportistas, escritores y muchos otros sobresalientes profesionales. Ellos contribuyen día tras día al progreso de un país en cuya identidad sus antecesores dejaron una seña indeleble.

\section{Referencias}

Álvarez Estévez, R. y Guzmán, M. (2012). Del Caribe somos. Santo Domingo: Funglode.

Álvarez Estévez, R. (1988). Azúcar e inmigración. La Habana: Editorial de Ciencias Sociales.

Batista, Y. y Paz, A. (2011). Influencia cultural de la inmigración jamaicana en la localidad de Guatemala. Contribuciones a las Ciencias Sociales, http://www. eumed.net/rev/cccss/13/

Carr, B. (1998). Identity, Class, and Nation: Black Immigrant Workers, Cuban Communism, and the Sugar Insurgency, 1925-1934. The Hispanic American Historical Review, 78(1), 91-109.

Castor, S (1978). La ocupación norteamericana de Haití y sus consecuencias. La Habana: Casa de las Américas.

Chailloux Laffita, G. (2002). La contribución antillana a la identidad cubana. Debates americanos, 12, 54-62. 
Chailloux Laffita, G. (2015). El trabajo que cruza el mar. La Habana: CEDEM. García Álvarez, A. (2008). La costa cubana del guineo. Una historia bananera. La Habana: Editorial de Ciencias Sociales.

Giovannetti-Torres, J. (2018). Black British Migrants in Cuba: Race, Labor, and Empire in the Twentieth-Century Caribbean, 1898-1948. Nuena York: Cambridge University Press.

Le Roy Cassá, J. (1929). Inmigración antisanitaria. La Habana: Dorrbecker.

McGillivray, G. (2009). Blazing Cane. Sugar Communities, Class and State Formation in Cuba, 1868-1959. Durham: Duke University Press.

Pérez de la Riva, J. (1979). Cuba y la inmigración antillana. 1900-1931. En J. Pérez de la Riva (Ed.), de estudios cubanos (t. 2, pp. 5-75) La Habana: Editorial de Ciencias Sociales.

Pérez Nakao, Y. (2019). La inmigración jamaicana en Banes (Tesis doctoral no publicada). Universidad de Holguín, Holguín, Cuba.

Pichardo, H. (Comp.). (1969). Documentos para la Historia de Cuba (t. 2). La Habana: Editorial de Ciencias Sociales.

Sánchez Guerra, J. (2004). Los anglocaribeños en Guantánamo (1902-1950). Guantánamo: Editorial El Mar y la Montaña.

Sintes, E.; Abreu, J., y Bellido, R. (2013). De isla a isla. Los canarios en el azúcar. Holguín: Ediciones Holguín.

Tellería, E. (1973). Los congresos obreros en Cuba. La Habana: Editorial de Arte y Literatura.

Zanetti, O. (2006). La república: notas sobre economía y sociedad. La Habana: Editorial de Ciencias Sociales.

Zanetti, O., y García Álvarez, A. (1976). United Fruit Company, un caso del dominio imperialista en Cuba. La Habana: Editorial de Ciencias Sociales. 



\section{Inmigrantes antillanos en Cuba: discursos económicos, raciales e identitarios, \\ 1910-1940}

\section{Consuelo Naranjo Orovio \\ Instituto de Historia-CSIC}

\section{Discursos sobre la inmigración y la nación}

La llegada de trabajadores antillanos a Cuba desde los primeros años de la década de 1910 suscitó un apasionado debate entre quienes consideraban que su presencia era un factor que retrasaría e incluso perjudicaría la integración nacional, lo cual, en su opinión, mermaría la soberanía nacional; y el sector azucarero, que demandaba la entrada de mano de obra que la industria azucarera necesitaba, especialmente en la época de zafra. La presión de este grupo, apoyándose en que el crecimiento económico del país, que dependía fundamentalmente de la producción de azúcar, inclinó la balanza a su favor. Sus solicitudes fueron escuchadas por distintos presidentes que reformaron la legislación migratoria, permitiendo la entrada de trabajadores antillanos, haitianos y jamaiquinos (fundamentalmente) cuando la industria azucarera así lo requirió.

La composición de los dos grupos a los que nos referimos era distinta. Aquellos que defendían la integración de la nación

5. Este trabajo es parte del proyecto "Connected Worlds: The Caribbean, Origin of Modern World". This project has received funding from the European Union's Horizon 2020 research and innovation programme under the Marie Sklodowska Curie grant agreement No 823846. Professor Consuelo Naranjo Orovio, Instituto de Historia-CSIC, directs this project. 
representaban la clase media y académica del país. Muchos intelectuales y científicos, al igual que otros colegas lo habían hecho en el siglo XIX, adujeron que la heterogeneidad de la población y de la cultura debilitaría a la nación al restarle coherencia y unidad. En estos debates fue frecuente que se equiparara la cultura con la etnia, o lo que en esos momentos llamaban "raza". Para estos intelectuales y científicos, la diversidad racial suponía una amenaza para el "porvenir de la nación". Aduciendo que la joven república debía tener un cuerpo social cohesionado, miraron con rechazo a los grupos migrantes con tradiciones culturales distantes a las del país, y abrazaron, en su mayoría, la herencia hispana, al considerarla uno de los componentes fundamentales de la cultura cubana. Esto no significa que no existieran debates sobre la propia herencia hispana, así como sobre el retraso de algunas de sus tradiciones y sobre la lacra que quizá suponían para alcanzar el progreso al que se aspiraba. Fueron necesarios algunos años para combinar tradición y progreso y situar el pasado español y su cultura en el seno de la cultura cubana. A ello, sin duda contribuyó la presencia de una colectividad española fuerte y nutrida, hasta bien entrada la década de 1930, con migrantes procedentes de distintas zonas de España.

Otro motivo de prevención de este grupo hacia los trabajadores antillanos y también hacia los chinos estuvo relacionado con cuestiones higiénicas y sanitaras. Sobre este aspecto adelantamos que fueron considerados inmigrantes "antisanitarios" al pensar que portaban enfermedades ya erradicadas en Cuba. Su presencia, por ende, representaba un daño tanto para la cultura como para la salud, pero también perjudicaría el trabajo de los nacionales y el desarrollo del movimiento obrero y sindical. La acusación de que su presencia mermaba las posibilidades de trabajo a los ciudadanos del país o a los migrantes "aptos" (como se consideraba a los españoles) tomó fuerza durante las crisis económicas que hicieron brotar la xenofobia contra aquellos de los que se pensaba que su contratación suponía una rebaja de los salarios, además de debilitar el movimiento obrero.

El debate sobre la conveniencia o no de la inmigración antillana contiene varios elementos de análisis que remiten, por una parte, a la estructura de la economía cubana y a las demandas continuas de asalariados temporales, $y$, por otra, al imaginario nacional que anhelaba y presentaba una nación blanca y homogénea, que se articuló a través de un discurso 
racial y nacionalista. Parte de este discurso nacionalista estuvo urdido con ideas anti-imperialistas. La opinión de ambos grupos sobre los obreros antillanos coincidió en la década de 1930, cuando la crisis económica culpó a los antillanos de ser responsables del deterioro económico, pero también social y cultural del país. Como ha ocurrido en diferentes países en distintos momentos, el inmigrante era el chivo expiatorio cuando las condiciones económicas empeoraban, el culpable de los males económicos, morales, sanitarios, políticos y sociales. La xenofobia en estas coyunturas a veces se alía con el racismo y mira hacia las colectividades de inmigrantes cuyas culturas son muy diferentes a la cultura del país receptor. Son momentos en los que la defensa de la "integridad nacional" se hermana con miedo al diferente tendiendo un manto oscuro sobre aquellos a quienes se considera una amenaza.

Frente al "peligro que representaba el extranjero" se establecieron controles para determinar la "calidad" de los inmigrantes no solo por su cualificación profesional, sino, sobre todo, por su capacidad de adaptación y de asimilación. Los intelectuales vincularon dicha capacidad con la procedencia de los trabajadores y la proximidad cultural entre la colectividad extranjera y la nacional. La homogeneidad cultural y "racial" era para muchos pensadores la base de la nación en la que el conjunto de ciudadanos se identificaba como parte de la misma. La idea de una cultura nacional homogeneizante, que era el punto esencial del discurso nacionalista (Anderson, 1983; Segal y Handler, 1993), que se oponía a la heteregoneidad y al mestizaje, recreó e imaginó la otredad y la heterogeneidad, en parte, a través de los discursos raciales y económicos que ensalzaban el miedo hacia el extranjero. El miedo y las barreras socioculturales levantadas contra los trabajadores antillanos tenían algunos rasgos comunes con las construidas contra la poblaciones negra y mulata en Cuba en el siglo XIX. Estas construcciones contribuyeron a reforzar el ideal homogeneizador de la cultura y de la etnicidad, a la vez que encontraron en su oposición un reforzamiento del grupo como élite dominante (Wade, 2002).

En la historia observamos que los hechos se sucedieron con rapidez. Lo hicieron al compás en que se modificaron las ideas y los proyectos que defendían la necesidad de recibir asalariados de otros países. Los antaño trabajadores beneficiosos para una sociedad se transformaron en 
Inmigrantes antillanos en Cuba: discursos económicos, raciales e identitarios, 1910-1940

delincuentes, degenerados, trasgresores de las normas, atorrantes y parásitos. En aquellos países en los que la inmigración no era algo puntual sino más bien estructural, muchos de estos migrantes pasaron a formar parte del hampa, de los bajos fondos en donde los juristas y los antropólogos situaban la "mala vida". Estos colectivos fueron elementos en la construcción de la otredad que tenía como centro al extranjero: el inmigrante. El tema es más complejo si añadimos otro dato referente a la interpretación de la conducta de los individuos a partir de su procedencia y se vincula el origen geográfico de las poblaciones y la idea de diferencias genéticas. La necesidad de ordenar la diversidad condujo a clasificar de las poblaciones en diferentes "razas", lo cual no solo justificaba, por ejemplo, la esclavitud, sino la creencia de que la procedencia geográfica y pertenencia a un pueblo o a una etnia determinada condicionaba la conducta y capacidad intelectual de las personas. La biologización de la cultura y la naturalización de las categorías raciales fueron una vuelta de tuerca en el proceso de criminalización del diferente, y mantuvieron los debates en torno a la barbarie de algunas poblaciones no europeas, que no se adecuaban al patrón civilizatorio occidental. Algunas prácticas culturales, por ejemplo, las religiosas de algunas poblaciones afrodescendientes o de los haitianos, fueron consideradas bárbaras y delictivas al representar no solo un elemento y suceso extraño a la cultura del país, sino también un ataque al orden social.

La historia encierra muchos ejemplos sobre las consecuencias encadenadas que provoca una crisis comercial o económica. Una de ellas se puede observar en la percepción negativa de los cambios que se han producido en la identidad colectiva con la llegada de migrantes. El temor a que las formas culturales de la identidad colectiva cambiaran y la "integridad nacional" mutara hizo volver la mirada a aquellos que tenían culturas distintas, a quienes se les acusó de haber causado el debilitamiento de los valores tradicionales y de la decadencia moral. Es decir, en los momentos en que las élites elaboraron un discurso de construcción nacional, también se recreó la heterogeneidad como un elemento necesario para la afirmación nacional (Wade, 2002).

También la historia nos enseña que los hechos no son únicos o extraños, no se suceden de manera aislada o compartimentada, ni tampoco acontecen de manera excepcional en algún o algunos países. Los hechos a los que aludo sobre la prevención contra el inmigrante, hasta llegar a su 
persecución y criminalización, responden a dinámicas sociales y culturales comunes a muchas sociedades. Ello no significa que, a lo largo de los siglos XIX y XX, en países como Argentina o Cuba, por ejemplo, la selección étnica de la inmigración impidiera la llegada de migrantes de distinta procedencia, tanto deseados como no deseados. Lo que apuntamos es que más allá de la legislación migratoria que priorizó a unos migrantes sobre otros por razones de procedencia y de "color", hubo momentos en que la visión sobre el inmigrante/extranjero cambió en un corto espacio de tiempo. Su resignificación guarda relación con los valores morales y culturales que se quieran resaltar, pero también con los proyectos económicos y sociales de la élite, por lo que "los discursos hegemónicos siempre serán ensamblajes complejos con elementos (ideas, símbolos, valores, prácticas) de distintos orígenes. El significado y la organización de estos elementos no son fijos y siempre son parciales, pueden ser "leídos" de distintas maneras, así como también pueden entrar y salir en el terreno de lo tácito de manera impredecible" (Wade, 2002, p. 33).

Argentina es un ejemplo representativo del debate en torno a la inmigración y del papel cambiante que se le asignó al migrante desde 1890 hasta entrada la década de 1910, cuando políticos e intelectuales dejaron de concebirlo como el "instrumento esencial en la creación de una sociedad y una comunidad política modernas” (Halperín Donghi, 1998). La crisis económica y financiera de finales de la década de 1880 en Argentina fue el catalizador de oposición entre la tradición y la modernidad que, en algunos países, como en este caso, forman parte de la tensión, ya mencionada, entre la homogeneidad y la heterogeneidad como dos realidades existentes y complementarias; la pugna entre distintas representaciones de la identidad nacional. Como comenta Hall (1996), "la unidad, la homogeneidad interna que el término identidad trata como fundacional, no es una forma natural sino construida de cierre, y toda identidad nombra como su otro necesario, aunque silenciado y tácito, aquello que le 'falta"' (p. 18).

Así mismo, las ideas que se esgrimieron en los momentos de crisis contra la inmigración, y de manera particular sobre determinados colectivos, forman parte de un sustrato ideológico latente del que se abastecieron los políticos e intelectuales para buscar las causas de la crisis, del desorden social, de la conflictividad laboral, de las protestas o de las huelgas. Lo 
importante no es si la xenofobia por sí misma, o si el racismo y la xenofobia cuando actuaron en común, tuvieron impacto en la legislación y en la política migratoria. Pienso que lo más trascendente de las ideas vertidas sobre los extranjeros e inmigrantes es su utilización posterior como argumentos apologéticos del orden social y de la unidad nacional. Los contenidos de la xenofobia y del racismo no fueron ni son puntuales, no brotan y desaparecen; su existencia es parte de la ideología más o menos nacionalista que se transforma en xenófoba y que a veces tiene connotaciones racistas. Los discursos que contienen estos planteamientos moldearon las mentalidades, levantaron barreras y contribuyeron a construir imaginarios nacionales. Por la vigencia del tema y de algunos de los problemas que hemos señalado, quizá fuera más exacto hablar en tiempo presente.

La migración de antillanos a Cuba en el siglo XX es parte de un proceso más amplio, transnacional y global que desde mediados del siglo XIX se mantiene hasta la actualidad. Como han estudiado varios autores, el desarrollo de las economías de plantación, especialmente bananeras y azucareras; las inversiones de capital norteamericano en la región del Caribe; la construcción del canal de Panamá, así como de carreteras y del ferrocarril en Panamá; o el servicio doméstico generaron una amplio movimiento migratorio transnacional desde Jamaica, Barbados, Dominica, Guadalupe, Haití, Martinica, Anguila, San Andrés, Providencia, Trinidad, Puerto Rico y Cuba, entre otras, en donde existía un excedente de fuerza laboral o bien donde la situación económica obligó a centenares de miles de personas a desplazarse en busca de trabajo. En muchas ocasiones no se trató de una migración temporal y puntual de ida y regreso. Muchos de los trabajadores optaron por permanecer en el nuevo país. Es un movimiento transnacional alimentado por las redes económicas, políticas y culturales (Duany, 2010). En esta migración los trabajadores se desplazaron, y continúan haciéndolo, por el continente americano entre distintos países en función de las demandas y de las oportunidades. En este activo movimiento de personas, las redes de los migrantes, como en todos los movimientos migratorios, tuvieron y tienen un rol importante.

El estudio que abordamos se centra en la presencia de antillanos en Cuba y en los debates que generó a partir de la década de 1910 hasta finales de los años treinta. En ellos encontramos factores de distinto cariz: económico, higiénico-sanitario, cultural y social. Muchos de ellos compartieron 
el elemento racial como base de la argumentación en contra de estos colectivos. Por ello, las discusiones en torno a los beneficios y perjuicios causados por su estancia en el país deben integrarse en una polémica más amplia en torno a la identidad nacional y cultural, en la cual la homogeneidad y la heterogeneidad son parte no solo del debate identitario, sino de la propia nación. Como ya comenté, dichos debates son parte de la pugna entre la homogeneidad y la heterogeneidad como realidades de la nación. Su estudio revelará qué identidad se estaba recreando y a través de qué diferencia se construía, ya que dichos discursos "emergen en el juego de modalidades específicas de poder y, por ello, son más un producto de la marcación de la diferencia y la exclusión que signo de una unidad idéntica y naturalmente constituida" (Hall, 1996, p. 17). Así mismo, esta identidad recreada se construye "dentro del juego entre el poder y la exclusión" en el cual actuaron factores de clase, económicos, culturales y raciales.

Los braceros antillanos fueron la principal mano de obra temporal que demandaron las compañías azucareras de Cuba. Para recibir estos trabajadores pusieron en marcha los mecanismos que aseguraron su contratación en distintas islas del Caribe, su llegada y trabajo a Cuba (Zanetti y García Álvarez, 1976). El período de mayor crecimiento económico coincide con el aumento de la inmigración de antillanos, entre 1912 y 1921; en estos años, esta inmigración fue aumentando de manera espectacular. Entre 1920 y 1930 entraron de manera oficial 139.449 haitianos y 65.800 jamaiquinos. A estas cifras hay que sumar las entradas ilegales. Tras la crisis de 1921, esta inmigración se redujo con la prohibición temporal de nuevas entradas. Ello supuso una disminución de la inmigración en el país, especialmente de jamaicanos.

Muchos se beneficiaron de las entradas de miles de trabajadores antillanos: la economía; los agentes que transportaban a los trabajadores desde desde isla vecinas como Haití, Jamaica, Barbados a los centrales azucareros; las compañías de navegación, y el Gobierno cubano, que cobraba entre $18 \$$ y $20 \$$ por cada trabajador introducido. En este comercio, varios factores inclinaron a los hacendados a preferir la contratación de estos braceros frente a los trabajadores del país o a los inmigrantes españoles. Las redes montadas para su contratación y traslado al país, la contratación a precios más bajos y su condición de extranjeros, ajenos a la cultura del país del que también desconocían su idioma, sin duda les 
Inmigrantes antillanos en Cuba: discursos económicos, raciales e identitarios, 1910-1940

hizo más vulnerables, además de mantenerlos alejados del movimiento obrero y sindical.

\section{Política y legislación migratorias en Cuba}

Desde los primeros años del siglo XX, la política y la legislación migratorias en Cuba guardaron una relación estrecha con los intereses económicos. Las primeras leyes guardan gran similitud con la legislación migratoria de Estados Unidos. La Orden núm. 155, promulgada en mayo de 1902 por el Gobierno interventor norteamericano, bajo Leonard Wood, contenía las normas que regulaban la inmigración en Cuba desde el 14 de abril de 1899, además de incluir otras disposiciones que remitían a las leyes de inmigración de Estados Unidos. En el primer cuerpo legislativo se prohibía la entrada de algunos grupos como los chinos, así como prostitutas, mendigos que pudieran ser una carga pública, idiotas, quienes hubieran sido condenados por cometer crímenes, e individuos que tuvieran distintas enfermedades físicas o mentales. Las fluctuaciones de la economía y la demanda de mano de obra, especialmente en la época de zafra, marcaron la llegada de trabajadores y la promulgación de leyes que aceptaban el ingreso al país de algunos migrantes considerados en otros momentos como no aptos.

Durante los primeros treinta años asistimos a un debate entre los grandes productores de azúcar, sobre todo las empresas norteamericanas, propietarias de la gran mayoría de los ingenios azucareros, que reclamaron continuamente la contratación de braceros de cualquier procedencia para asegurarse un suministro continuo y a costes reducidos, y la clase media del occidente del país, que, encabezada por un sector compuesto por intelectuales y profesionales, mostró su preocupación por la entrada en el país de poblaciones "ajenas" a sus costumbres y de distinto origen étnico. Para este grupo era preciso controlar la inmigración a partir de la selección étnica que asegurara la llegada de personas que contribuyeran a hacer una nación sólida y soberana, teniendo en cuenta la proximidad tanto cultural como étnica entre la población cubana y los inmigrantes. Para ellos, la heterogeneidad de la población ponía en peligro la cohesión e integridad de la nación, la nacionalidad y la soberanía. La cohesión y la integración eran elementos imprescindibles para que la joven república lograra ser un país 
dueño de su destino. A partir de este sentimiento nacionalista, alentado en todo momento por el antiimperialismo, defendieron la inmigración blanca por familias que se asentasen y se arraigasen en el país, y la contratación de asalariados también blancos. Desde 1905, la presión de las compañías motivó un cambio en la legislación migratoria que fue abriendo sus puertas a la entrada de trabajadores destinados a las zonas donde se localizaban los centrales azucareros. La United Fruit Company promovió el primer plan de inmigración en 1905 para la contratación de 300 canarios para trabajar en las zonas de Banes y Nipe, 200 hombres solos y 100 con sus familias. En 1906, el general Menocal, administrador de los centrales azucareros Delicias, Chaparra y San Manuel, solicitó la aprobación de un nuevo plan de inmigración por el cual el Estado se encargaría de pagar el billete a 75 familias, peninsulares y canarias, que se repartirían a partes iguales en uno de los centrales. En 1906, el presidente de la Compañía Azucarera El Lugareño presentó un proyecto de inmigración para la introducción de 60 familias canarias, un total de 250 personas, cuyo transporte correría a cargo del Estado. Los trabajadores recibirían un jornal de 80 centavos oro español, asistencia médica y medicinas gratuitas, además de poder llegar a ser propietarios de la tierra y establecerse como colonos. ${ }^{6} \mathrm{La}$ falta de mano de obra dejó sin moler 100.000 y 200.000 toneladas de azúcar en 1906 y 1907, por lo que en 1907 se volvió a solicitar al Gobierno que autorizase la entrada de braceros. ${ }^{7}$ Años después, el aumento en la producción de azúcar demandó la llegada de mayores contingentes de braceros que se buscaron en las islas cercanas: Haití, Jamaica, Barbados, Granada, Aruba, Puerto Rico y Curaçao. Para ello, el Gobierno promulgó distintas leyes y decretos que autorizaban su importación. En 1913, el presidente José Miguel Gómez autorizó la contratación de estos braceros para trabajar en la Nipe Bay Company. Los Decretos núm. 999 de 23 de octubre de 1913 y núm. 1.173 de 10 de diciembre de 1914 abrieron la puerta de entrada a los obreros que habían trabajado en la construcción del canal de Panamá, a quienes se les concedían franquicias.

6. Archivo Nacional de Cuba, La Habana (ANC), Fondo Secretaría de la Presidencia, leg. 115, núm. 92.

7. ANC, Fondo Secretaría de la Presidencia, leg. 21, núm. 8. 
Inmigrantes antillanos en Cuba: discursos económicos, raciales e identitarios, 1910-1940

La entrada de jornaleros requirió que se habilitasen estaciones sanitarias en varios puertos del país. Además de La Habana, se habilitaron en Cienfuegos, Santiago de Cuba y Nipe (Decreto núm. 753 de 26 de agosto). ${ }^{8}$ Unos años después, el control de las entradas oficiales pudo hacerse con mayor rigor tras crearse el servicio de inspección dactiloscópica por el Decreto núm. 302 de 23 de marzo de 1914. La coyuntura internacional provocada por la Primera Guerra Mundial tuvo un efecto inmediato en la legislación migratoria que flexibilizó los requisitos de entrada adaptándose a las necesidades del mercado cubano. La Ley de Inmigración de 3 de agosto de 1917 actuó como marco legal de la inmigración contratada hasta 1926. Mediante esta ley se autorizaba la entrada libre de braceros para trabajar en los campos de caña hasta los dos años siguientes a que finalizase el conflicto, bajo las condiciones estipuladas en su art. $1^{\circ}$, que continuaba poniendo especial atención en las medidas higiénico-sanitarias con el fin de garantizar que los nuevos inmigrantes no eran portadores de enfermedades infecciosas, que se dedicarían a actividades productivas y no serían carga pública. El 12 de diciembre de 1917, el Decreto núm. 2.258 ponía término a la política migratoria de los años de bonanza económica. Las medidas legislativas de los años siguientes estuvieron dirigidas a controlar la entrada de extranjeros, que fueron acusados de ser los responsables de los negocios de droga y prostitución. Las restricciones y el control en los puertos para evitar la llegada de clandestinos se reforzaron a través de los Decretos núm. 384 , art. ${ }^{\circ} 15$, de 2 de marzo de 1925, y el núm. 504, de 1 de abril de $1926 .{ }^{9}$

La crisis sobrevenida tras la "Danza de los Millones" y el crack de 1929 dio un golpe de timón en la legislación migratoria. En 1930, la ley de inmigración limitó la entrada a aquellos que no supieran leer y escribir en castellano, además de establecer un requisito para los menores de 21 años, que deberían contar con el respaldo de un comerciante solvente en Cuba que previamente garantizara en el Departamento de Inmigración la manutención y el trabajo del recién llegado; además, el joven también estaba obligado a acudir a las clases impartidas en los centros regionales

8. Este decreto también incluía la otorgación de 13.000 a la Secretaría de Sanidad y Beneficencia para el fomento de la inmigración. ANC, Fondo Secretaría de la Presidencia, leg. 121, núm. 12. 9. ANC, Fondo Secretaría de la Presidencia, leg. 121, núm. 68. 
españoles a fin de completar su instrucción, al menos hasta la mayoría de edad. Otra de las imposiciones marcadas en la Ley de 1930 fue la limitación de la entrada a los mayores de 55 años y a las mujeres menores de 21 años, a no ser que estuviesen casadas en Cuba o fueran acompañadas por familiares. Estas disposiciones prácticamente limitaban la entrada a españoles jóvenes que tuviesen amigos o parientes solventes y residentes en el país, asegurándose de este modo que los recién llegados no serían una carga para el Estado. En esta ley también se establecieron las cuotas que el inmigrante debería pagar diariamente en el campamento de inmigración de Triscornia y en el que debían permanecer quienes tuviesen que guardar cuarentena o bien esperar a ser contratados. Las cuotas ascendían a $0,30 \$$ por su manutención y $3 \$$ diarios por su alojamiento. Si el inmigrante tenía que recibir atención médica, además debía pagar $0,80 \$ .^{10}$

\section{Propuesta para seleccionar el tipo de inmigrante}

Como en otros momentos y países, en Cuba, en el discurso anti-inmigrantes $y$, en este caso, anti-trabajadores antillanos, se utilizaron argumentos que los convertían en "inmigrantes indeseados". La higiene, la sanidad, el trabajo y la cultura fueron las puntas de lanza del discurso racista y xenófobo. La presencia de los antillanos suponía un peligro para la situación sanitaria del país al ser portadores de enfermedades ya radicadas en Cuba, lo que trataron de demostrar algunos médicos según veremos a continuación. También se les acusó de mermar las posibilidades de trabajo a los cubanos al contratarse por un salario menor, ya que estaban al margen de las reivindicaciones que el movimiento obrero realizaba. Consideraron que su contratación repercutía de manera negativa en la clase obrera del país, que vio descender su capacidad adquisitiva y nivel de vida, y que su trabajo debilitaría la cubanidad, ya que reforzaba la dependencia de los colonos cubanos o españoles frente a las compañías norteamericanas. Por último, pensaron que su cultura e idiomas diferentes a los del país también ponían en riesgo la integridad de la cultura cubana, concebida como un elemento estático e invariable a lo largo del tiempo (Ibarra, 1992, pp. 155-170; Naranjo Orovio, 1998, 2001, 2005). La

10. ANC, Fondo Secretaría de la Presidencia, leg. 121, núm. 67. 
valoración como individuos nocivos a la sociedad formaba parte del imaginario cultural y de la construcción del otro realizada por la élite blanca que procedía de siglos anteriores. La peligrosidad que entrañaban las personas no blancas, catalogadas como grupos "de color", fue un sentimiento heredado cuyas consecuencias permearon la práctica social cotidiana. El miedo provocado no solo fue un elemento de control político y social en el siglo XIX; su función permaneció en el siglo XX como un instrumento de control, catalizador de las tensiones socio-raciales. La vinculación que se estableció desde el positivismo lombrosiano entre la procedencia étnica del individuo y la propensión a delinquir derivó en la consideración que se tuvo hacia ese "otro", representado por el negro, el mulato, el chino o el inmigrante no blanco, a quienes se consideraba individuos a los que había que controlar por su tendencia a delinquir.

La Quinta Conferencia de Beneficencia y Corrección de la Isla de Cuba, efectuada en 1906 en Santiago de Cuba, se dedicó en parte a debatir cuál era la política migratoria que el Gobierno debía adoptar, las medidas y normas que deberían acordarse para que el inmigrante no fuera una carga pública ni un agente perturbador del orden social. Sin duda pensando en lo que estaba ocurriendo en otros países del continente con la llegada de inmigrantes socialistas y anarquistas, los asistentes a esta conferencia también trataron de impedir que el inmigrante fuera "el fermento de las agitaciones económicas" y de agitaciones políticas por "los ideales socialistas, ya digeridos por el proletariado europeo" que derivasen en "un trastorno revolucionario".

En esta conferencia, en la que participaron juristas, antropólogos, maestros, escritores y médicos como Fernando Ortiz, Federico Córdova, Juan Santos Fernández, Diego Tamayo, Guillermo Dolz, Ramón Meza, Omelio Freyre y Luis de Solo, se presentaron estudios sobre los beneficios y perjuicios que la inmigración ocasionaba con el fin también de saber qué tipo de inmigrante era el más apto. Como en otros países que recibían inmigrantes, los reunidos coincidieron en señalar que la procedencia del individuo era el aspecto más importante a la hora de priorizar unos inmigrantes frente a otros. Los estudios sobre criminalidad adquirieron un notable interés al servir de base para argumentar a favor o en contra de la llegada de distintos grupos de migrantes (Ortiz, 1906a, 1906b). Según las estadísticas de criminalidad que Fernando Ortiz presentó en la conferencia, los grupos que 
tenían un elevado índice de delincuencia eran los chinos, los negros y los mestizos por lo que se aconsejaba prohibir la entrada de asiáticos y africanos $y$, en general, de cualquier individuo que no hablara un idioma europeo. En sus intervenciones, Ortiz indicó que la inmigración blanca compuesta por familias de agricultores españoles era la más conveniente por ser la que se adaptaba mejor al país debido a la similitud cultural. De igual manera pensaban Federico Córdova, secretario de los comités seccionales de protección al inmigrante; Omelio Freyre Cisneros, catedrático supernumerario de segunda enseñanza de Camagüey, y Ramón Meza, delegado de la Sociedad Económica de Amigos del País y director del comité de protección al inmigrante. Federico Córdova destacaba la ventaja de que los inmigrantes tuvieran una proximidad cultural con los habitantes de Cuba, recordando que los canarios habían demostrado ser los más aptos, y en concreto la llegada de familias (Córdova, 1906). Omelio Freyre también se mostró partidario de que la inmigración española por familias era la más aconsejable para el país (Freyre, 1906). Para Ramón Meza, la inmigración de personas blancas era la que más contribuiría al progreso económico y social. Las tesis presentadas inclinaron la balanza hacia quienes consideraban que la asimilación en el país era una garantía de que los inmigrantes no pasarían a formar parte del hampa, de la mala vida o de los bajos fondos donde el delito era algo común y cotidiano. Aunque Cuba aún no recibía inmigrantes antillanos, la posibilidad de que llegara el momento en que estos arribaran estuvo presente en la conferencia. Fue Fernando Ortiz quien señaló que la adopción de las medidas recomendadas sería suficiente en ese momento en el que no parecía probable "una inmigración en masa de negros haitianos o norteamericanos".

El volumen que la inmigración había adquirido en varios países de América suscitó la preocupación entre políticos y médicos sobre cómo controlarla de manera que su entrada no afectase al país desde un punto de vista sanitario e higiénico. En 1911, el Gobierno envió una comisión de médicos a Hamburgo para que estudiasen el plan de medidas sanitarias que allí habían elaborado para aplicar a los inmigrantes. Tras el estudio, Arístides Agramonte remitió un informe al secretario de Sanidad y Beneficencia, Manuel Varona Suárez, comentando que desde el siglo XIX en Alemania se aplicaban medidas para controlar a los migrantes que habían impedido la entrada al país de enfermedades infecciosas procedentes de países como Rusia y Austria-Hungría. Por ello, aconsejaba que se 
adoptasen medidas similares en Cuba y de esa manera se lograra impedir la entrada de personas con enfermedades infecciosas (Agramonte, 1911). En 1921, desde la Secretaría de Sanidad se desarrolló un programa que contemplaba la apertura de nuevas estaciones sanitarias en las zonas de mayor desembarco de inmigrantes como eran los puertos de Santiago de Cuba, Antilla y Nuevitas (Álvarez Estévez, 1988).

En América, el control de la inmigración se convirtió en uno de los principales asuntos abordados en los congresos de medicina, higiene y eugenesia realizados en la década de 1920, como la Quinta Conferencia Panamericana de Higiene, que tuvo lugar en Santiago de Chile en 1923; la Primera Conferencia de Eugenesia y Homicultura, celebrada en La Habana en 1927, y la Segunda Conferencia Internacional de Emigración e Inmigración, efectuada en La Habana en 1928. Uno de los temas de esta conferencia fue establecer las medidas que asegurasen la repatriación de los inmigrantes que no fueran aceptados en el país, votándose a favor de que fuera el gobierno del país de procedencia el que se responsabilizara de la misma. Haití, presente en esta reunión, votó en contra de esta medida. Junto a esta propuesta hubo otras de mayor calado sobre el control de la inmigración, que formaron parte de debates más amplios sobre la intervención que el Estado podía realizar para asegurar que la población fuera "sana", lo que en ese contexto significaba el "mejoramiento racial y sanitario" de la población. En Cuba Domingo Ramos fue uno de los defensores de aplicar los principios eugenésicos a la inmigración. El plan lo presentó en el Código de Eugenesia y Homicultura en la Conferencia de 1927. En él aconsejaba hacer pruebas germinales y somáticas a los inmigrantes con el fin de detectar posibles taras o enfermedades (García González y Álvarez, 1999, 2007). Estas polémicas tuvieron eco en las asociaciones científicas de cada país en las que los médicos presentaron estudios con el mismo propósito: buscar qué tipo de migrante era el más adecuado para formar una sociedad "sana" desde el punto de vista eugenésico. Uno de ellos fue Juan Santos Fernández, quien, en 1920, en la Academia de Ciencias Médicas, Físicas y Naturales de La Habana, planteó que el Estado debía desarrollar una política para vigorizar y depurar la población acorde con lo que otros colegas defendieron en distintos congresos realizados en América para controlar la inmigración desde un punto de vista sanitario, higiénico y eugenésico (Santos Fernández, 1920). 
En este contexto, la inmigración antillana recibió especial atención, más aún cuando desde los primeros años de la década de 1910 su flujo comenzó a aumentar como consecuencia de la extensión del cultivo de azúcar y la intensificación de su producción. En las décadas de 1920 y 1930, cuando la inmigración antillana alcanzó un volumen considerable, debido a la expansión de la producción azucarera y a la cotización que el azúcar adquirió en el mercado mundial, se levantaron varias voces contra lo que algunos consideraban la "invasión antillana" (Carr, 1998). El origen de algunas de las denuncias fue el negocio que el Gobierno había permitido en la venta, más o menos fraudulenta, de las autorizaciones para introducir antillanos, una denuncia que apareció en el Heraldo de Cuba el 21 de diciembre de 1921. A ello respondió rápidamente el secretario de Agricultura, el general Betancourt, diciendo que el Gobierno exigía como garantía 20 pesos por cada antillano introducido. Este depósito serviría para cubrir los gastos de repatriación del bracero una vez que finalizara su contrato. El mismo periódico, el 22 de diciembre de 1921, también publicó el comentario del general Betancourt quien se mostraba partidario de dicha inmigración a la que estimaba "conveniente, necesaria y patriótica; y aunque me critiquen, aunque me censuren, autorizaré las inmigraciones haitianas con la condición expresa de que se radiquen solamente en Camagüey u Oriente. Es necesario traer brazos a Cuba de donde se encuentren para obtener una gran zafra [...]" (Pérez de la Riva, 1979, p. 31). Frente a esta opinión, muchos intelectuales y científicos consideraron que la entrada de jornaleros antillanos y asiáticos representaba una amenaza para el país tanto desde el punto de vista médico como económico, cultural y moral. En la búsqueda de una población "equilibrada" y "sana", Juan Guiteras llegaba a afirmar que el campesinado blanco cubano era el verdadero portador de las cualidades deseables de la identidad y de la nación. Para este médico la provincia de Camagüey, con un porcentaje elevado de población blanca, era donde se encontraba "la verdadera alma del pueblo cubano". En sus campos, comentaba Guiteras, que no habían sido "invadidos por los negros", el campesino era "el tipo más hermoso de la raza blanca en Cuba; altos, bien formados, de ojos claros, fina tez blanca, tostada por el sol, y de pelo negro" (Guiterras, 1913, pp. 98-118). En 1920, Julio F. Arteaga publicó en los Anales de la Academia el estudio titulado "Plan de una campaña sanitaria contra el paludismo en la República de Cuba”, en el que criticaba la escasa atención que el Gobierno prestaba a los asuntos 
relacionados con la sanidad y la inmigración a los que anteponía los intereses económicos. En respuesta a esta crítica, el Gobierno envió a Mario G. Lebredo y Florencio Villuendas para que evaluasen la situación sanitaria de las provincias de Camagüey y Oriente, que albergaban un mayor número de braceros antillanos y asiáticos. A los informes que emitieron sobre la deficiente situación sanitaria de estas zonas que fue atribuida a la presencia de estos inmigrantes, se unieron otros estudios que aconsejaban que la prohibición de estas migraciones. Así lo manifestaron el director interino de Sanidad, Adam Galarreta, y el médico eugenista Francisco María Fernández que en 1921 se opusieron a la entrada de antillanos por considerarlos "un baldón de ignominia para nuestro país, y un peligro cierto de enfermedades repugnantes, que atacan la vitalidad de la raza” (Fernández, 1921, p. 209). Esta idea fue compartida por Juan Guiteras, quien se refería a la presencia de haitianos y jamaicanos como una "peligrosa inmigración", y por Jorge Le-Roy, cuya opinión en contra de las inmigraciones antillanas y asiática, a las que se refería como "funestas" por ser portadoras de enfermedades ya radicadas en el país o de incrementarlas, tuvo especial influencia, dada su posición de director del departamento de Demografía Sanitaria Nacional de la Secretaría de Sanidad y Beneficencia. En algunas publicaciones, Le-Roy vinculaba la evolución del paludismo en distintas partes del territorio con la presencia de braceros antillanos con la prevalencia de la enfermedad. En su estudio puso como ejemplo las provincias occidentales y centrales, donde la incidencia de la enfermedad había disminuido de manera progresiva y considerable, y las provincias de Camagüey y Oriente, zonas de expansión del latifundio azucarero, en las cuales desde 1913 la mortalidad por paludismo había aumentado. Las cifras se habían cuadruplicado de 1913 a 1916 en Camagüey, y casi duplicando en Oriente (Le-Roy, 1923). Del mismo autor es interesante el artículo que publicó en 1923-1924 en los Anales de la Academia de Ciencias Médicas, Físicas y Naturales de La Habana titulado "Sobre inmigración anti-sanitaria". En él hacía referencia a varios artículos publicados en el Heraldo de Cuba y el Diario de la Marina, en 1922 y 1923, sobre los daños y males sociales que ocasionaba al país la presencia de antillanos. En ellos se acusaba a los haitianos de practicar brujería y a los jamaicanos de vagancia y de ejercer la prostitución (Le-Roy, 1923-1924).

Las intervenciones y publicaciones de Le-Roy suscitaron un intenso debate entre el sector que opinaba como él y quienes, como Arístides 
Agramonte, pensaban que el país necesitaba inmigrantes, especialmente para trabajar en la recogida de azúcar, por lo que debía permitirse su entrada bajo un cierto control sanitario. Para llevarlo a cabo propuso que solo se autorizara la entrada de inmigrantes por los puertos que tenían los medios sanitarios apropiados, y que, por ejemplo, contasen con hospitales de aislamiento. ${ }^{11}$ Otros añadieron que el aumento de personal y material sanitarios también contribuiría a evitar las epidemias, apuntando que lo importante era controlar las entradas clandestinas que se producían sobre todo por el este de la isla. Terminadas las discusiones, los miembros de la Academia de Ciencias Médicas, Físicas y Naturales de La Habana acordaron remitir un informe completo de las mismas Alfredo Zayas, presidente de la República, en el que alertaban a los poderes públicos acerca de los peligros tanto en el orden sanitario como en el social que entrañaba esta inmigración, catalogada como "inmigración anti-sanitaria”, una inmigración compuesta en su opinión por elementos "no deseables":

Habana, 17 de diciembre de 1923

Honorable Sr. Presidente de la República

Honorable Sr. Presidente:

Esta Academia, atenta siempre al bienestar y prosperidad de la República, y velando por los sagrados intereses del país, ha estudiado en más de una ocasión los problemas relacionados con la salud del pueblo, y actualmente al ocuparse de los peligros que para la misma entraña la entrada de elementos peligrosos, por ser portadores de enfermedades infecciosas y transmisibles y de difícil vigilancia por su género de vida dentro del territorio de nuestra patria, así como por ser de costumbres viciosas y criminales que afectan directamente el orden social, discutió ampliamente en su sesión pública ordinaria del 14 del actual el problema inmigratorio de elementos no deseables y acordó llamar de nuevo atentamente la atención de los Poderes públicos acerca de los peligros que para la salud del pueblo cubano y tanto en el orden sanitario como en el social entraña la

11. "Acta de la sesión pública ordinaria del 14 de diciembre de 1923", Anales de la Academia de Ciencias Médicas, Físicas y Naturales de La Habana (1923-1924), 60, p. 417. 
Inmigrantes antillanos en Cuba: discursos económicos, raciales e identitarios, 1910-1940

inmigración de elementos no deseables y formula otra vez sus advertencias hacia la responsabilidad que contraen ante la nación todos aquellos que con el pretexto de favorecer los trabajos agrícolas y la industria azucarera autorizan y fomentan la entrada de extranjeros portadores de enfermedades transmisibles y vectores de costumbres viciosas y criminales.

Queda de usted Hon. Sr. Presidente, con la más distinguida consideración, (f.) José A. Presno

Presidente. ${ }^{12}$

Desde otros medios también se atacaba la entrada de estos trabajadores, que "se contentan con jornales exiguos que nos bastarían a satisfacer a medias las necesidades de nuestros braceros", según el artículo publicado el 14 de mayo de 1919 en el periódico La Lucha, titulado "Los problemas de la inmigración". A pesar de reconocer que su presencia era lo que podríamos decir "un mal necesario", el periodista recogía el debate que desde el siglo XIX se extendió por el continente americano en torno a qué tipo de inmigrante era más apto:

¿Será que el bienestar de Cuba y su futuro engrandecimiento nacional convenga más asemejarse a la semi-bárbara y turbulenta Haití, con sus generales de opereta bufa, sus brujos bebedores de sangre humana y su fetichista en lugar de aspirar a ser una hermana gemela de la Argentina, con sus sabios artistas, escritores, marinos, comerciantes, industriales, obreros y agricultores vaciados en los moldes de la cultura y el progreso técnico europeos?

La polémica sobre el inmigrante deseado continuó en los años siguientes, cuando la entrada de antillanos, especialmente de haitianos, se incrementó. Tal como indica Jorge Giovannetti-Torres (2018), entre 1925 y 1930, las llegadas ascendieron a 69.226 haitianos. Según los datos de Emilio Roig de Leuchsenring (1925), la afluencia de haitianos y jamaicanos había aumentado a partir del segundo semestre de 1927, tras la autorización del gobierno para introducir 14.500 braceros antillanos: 4.000 a la Atlantic Fruit and

12. "Acta de la sesión pública ordinaria del 14 de diciembre de 1923", Anales de la Academia de Ciencias Médicas, Físicas y Naturales de La Habana (1923-1924), 60, pp. 411-418. 
Sugar of Cuba y 10.500 a la United Fruit Company. Los trabajadores serían destinados a trabajar en los centrales azucareros Tánamo, Preston y Boston. El aumento de entradas avivó la discusión en torno a estos migrantes. En 1927, Luis Marino Pérez recogió todos los argumentos en contra de estos trabajadores en el artículo titulado "La inmigración jamaiquina desde el punto de vista social, económico y sanitario" (Pérez, 1927). Aun reconociendo la necesidad de su contratación para el crecimiento económico, mostraba su recelo por la "africanización" de la parte oriental de Cuba, lo que en sus palabras convertiría el Oriente "en una región predominantemente negra, planteando un problema de raza que debilitará a la nación cubana". El miedo a que se perdieran los valores "tradicionales-nacionales" cobra fuerza, según se lee en el artículo, y se enfatiza en los efectos nocivos que su presencia tenía en la cultura y el progreso de Cuba:

El negro cubano no puede desconocer que su mejoramiento social depende de su asociación al blanco. No es que la superioridad esté en la raza; así es que el negro hace solo dos generaciones que salió de la esclavitud, y se halla aún en gran atraso económico e intelectual, perteneciendo la mayor parte de los individuos de color a las clases más pobres y menos ilustradas. Por consiguiente, cuanto más numerosos son, tanto más dificultoso ha de ser para ellos mismos su progreso como raza.

Proponía que en los contratos se especificara que los migrantes volverían a su país tras finalizar el contrato ya que si no fuera así la migración antillana debería prohibirse, al igual que habían hecho en el caso de la migración china. Así mismo, el autor se mostraba preocupado por la situación médico-sanitaria de estos migrantes al llegar al país. Según él había observado en una visita a Jamaica, los certificados y exámenes médicos que hacían constar que los trabajadores estaban sanos se basaban fundamentalmente en un análisis de sangre, sin que en él se examinase si padecían enfermedades venéreas u otras como paludismo, tracoma o uncinariasis.

En este debate también participó Luis Araquistain (1928), quien, tras su viaje a Cuba, Puerto Rico, República Dominicana y Haití, entre 1926 y 1927, recogió sus reflexiones en el libro La agonía antillana, publicado en 1928. En él, así como en el artículo "La Africanización de Cuba", de 1927, Araquistain sopesaba distintos factores y procesos que habían 
Inmigrantes antillanos en Cuba: discursos económicos, raciales e identitarios, 1910-1940

actuado en la formación de las Antillas, así como de su identidad, llamando la atención sobre la importancia que tenía la colonización que era responsable de la evolución económica, demográfica, social y cultural. Para él, el factor principal y determinante de los proyectos colonizadores europeos en el área era la transformación de estas islas en colonias de plantación que requirieron la entrada de millones de africanos esclavizados frente a una minoría blanca en la mayoría de las Antillas no hispanas. Si bien este fenómeno también se había producido en las Antillas gobernadas por España, Araquistain indicaba que el proceso colonizador era diferente, ya que, en estas, España había aportado, lo que él llamaba el "germen de nacionalidad y civilización". El problema o el drama se planteaba en el presente, cuando Araquistain redactaba el libro, al considerar que Cuba en poco tiempo se "africanizaría" debido a la introducción de braceros antillanos para trabajar en las compañías azucareras norteamericanas. La voz de alerta del intelectual español era similar a la de los patricios cubanos que desde había tiempo denunciaban la disolución de la cultura y de la nacionalidad cubanas. Para Araquistain, la africanización era un hecho:

[...] Cuba quiso, con derecho innegable, con razón ideal incontrovertible, emanciparse de España, ser ella misma, americana, antillana, cubana; pero el hecho es que, al cabo de un cuarto de siglo de independencia nominal, hoy se está africanizando más que nunca. El cubano trató de desalojar al español; pero el negro, con sus menores necesidades, acabará expulsando al español y al propio cubano [...] Las grandes emigraciones extranjeras han sido siempre un peligro de disolución para las nacionalidades que las reciben o por lo menos una rémora en su formación. En el caso de los negros antillanos en Cuba esos inconvenientes se agudizan: por mutuos prejuicios de raza, por notables diferencias en el nivel de la cultura y por hablar lenguas distintas de la española, francesa los haitianos e inglesa los jamaiquinos. En tales circunstancias la asimilación es casi imposible. Pero el peligro máximo: que se disuelva la nacionalidad.

El artículo publicado por Araquistain, "La Africanización de Cuba", levantó algunos recelos en los círculos diplomáticos e intelectuales de Cuba. Uno de ellos fue Mario García Kohly, embajador de Cuba en España, quien mostró su protesta por lo que consideraba una ofensa para el país y para un 
sector de su población. A favor de Araquistain medió el historiador Emilio Roig de Leuchsenring, quien ya había manifestado su preocupación por lo que él como otros intelectuales cubanos consideraban la "pérdida de la nacionalidad". En 1924 en la conferencia "La colonia superviva", leída en la Sociedad Cubana de Derecho Internacional, se pronunció de manera contundente en contra de la entrada de antillanos y de chinos:

[...] por su baja civilización e inadaptabilidad a todo progreso y mejoramiento cultural y sanitario, su poco poder asimilativo no ya con el blanco nativo o extranjero, sino también con el negro cubano, formado en las poblaciones o campos donde residen verdaderas colonias, apartadas por completo de nuestra nacionalidad. No es por tanto ésta, la inmigración que debe desear todo país: la que además de condiciones relevantes de civilización, cultura y sanidad, se asimila fácilmente a la sociedad en que emigra, diluyéndose por absorción en ella y que contribuyen de esta manera a la unidad, robustecimiento y mejoramiento de la estructura nacional. [...] Y si no existe esclavitud negra, la trata negra sí continúa, con la única diferencia de que ahora, en vez de hacerse con África, se hace con Jamaica y Haití (Roig de Leuchsenring, 1925).

En el artículo titulado “¿Se está Cuba africanizando?”, aparecido en la revista Carteles en octubre de 1927, Roig de Leuchsenring matizó las palabras del político e intelectual español, así como el uso que hacía del término "africanización". Tratando de "(des)racializar" el término, insistía en sus connotaciones culturales explicando que el adjetivo de "indeseable" no guardaba relación con el origen africano de los migrantes, sino por su menor grado de civilización, lo que les convertía en individuos que podían ser explotados más fácilmente por el "capitalismo extranjero" (Roig de Leuchsenring, 1927a). En un artículo posterior, Roig de Leuchsenring (1927b) añadía otros argumentos al debate sobre las migraciones antillana y china, a las que acusaba de privar de trabajo bien remunerado al obrero y campesino cubanos y al buen inmigrante, favoreciendo "el acaparamiento cada vez mayor del suelo y riquezas cubanas por los trusts norteamericanos y la mayor ganancia de éstos con el menor costo posible aún en las peores épocas de crisis económica nacional, sin beneficio alguno para la República”. 
Inmigrantes antillanos en Cuba: discursos económicos, raciales e identitarios, 1910-1940

Los datos de entrada de inmigrantes en Cuba avalaron sus temores, compartidos por otros intelectuales, por el cambio drástico de los flujos migratorios que en los últimos años habían favorecido la entrada de antillanos frente a la tradicional y deseada inmigración española. Este cambio de tendencia se reflejaba en las estadísticas que mostraban que en el primer semestre de 1927 habían entrado unos 26.756 haitianos y jamaicanos, y 9.650 españoles habían tenido que abandonar el país por falta de trabajo, situación que se agravó en el segundo semestre, en el que 12.000 españoles habían sido repatriados. ${ }^{13}$ A mediados de diciembre de 1927, Roig Leuchsenring de nuevo publicó otro artículo en Carteles, titulado "Lo más negro de nuestra actual africanización no es el negro", en el que abiertamente criticaba la política migratoria del Gobierno al permitir la entrada de braceros haitianos y jamaicanos:

[...] los que consienten y autorizan año tras año, la entrada de esos inmigrantes, indeseables, verdaderos aventureros del trabajo, de escasísima civilización, pésimas condiciones sanitarias, bajo nivel moral, no asimilables a la población cubana, analfabetos en su mayoría, [...] debían cerrarles el paso a esos inmigrantes, no dando más autorizaciones para el embarque de haitianos, jamaiquinos ni otros inmigrantes "nocivos" al país, reglamentando debidamente la inmigración para que no entren, declarados o disfrazados (Roig de Leuchsenring, 1927c).

La prensa también sacó a la luz otros hechos que criminalizaron a los antillanos, especialmente a los haitianos y a sus prácticas religiosas. Su condena tomó más fuerza cuando, en los primeros años del siglo XX, los periódicos publicaron varias noticias sobre crímenes o desapariciones de menores que se atribuyeron a los practicantes de la religión afrocubana, incriminándose a los brujos y en ocasiones a haitianos. La primera que conocemos refiere el asesinato de la niña Zoila, secuestrada en 1904 en

13. Entre 1912 y 1927 las entradas de antillanos en Cuba que recoge Emilio Roig de Leuchsenring son las siguientes: jamaiquinos: 1912, 709; 1913, 2.258; 1914, 1.791; 1915, 1.834; 1916, 7.122; 1917, 7.884; 1918, 9.184; 1919, 24.187; 1920, 27.088; 1921, 12.469; 1922, 4.455; 1923, 5.844; 1924, 5.086; 1925, 4.747; 1926, 2.508; 1927, 1.397. Haitianos: 1912, 233; 1913, 1.200; 1914, 98; 1915, 2.453; $1916,4.922 ; 1917,10.136 ; 1918,10.640 ; 1919,10.044 ; 1920,35.971 ; 1921,12.483 ; 1922,639 ; 1923$, 11.088; 1924, 21.013; 1925, 18.750; 1926, 12.346; 1927, 10.859 (Roig de Leuchsenring, 1925). 
Güira de Melena, en la provincia de La Habana. A esta le sucedieron otras noticias sobre el crimen de la niña Luisa, en Alacranes (Matanzas), en 1908; los asesinatos de los niños Onelio García y Marcelino López, ocurridos en la provincia de Matanzas, en 1915 y 1919; el crimen de la niña Cuca en 1922, sucedido en el central Francisco, en Camagüey, y el crimen de la niña Cecilia, en 1923. Como en otras ocasiones, tras conocerse la muerte de Cuca, en un primer momento se inculpó a un jamaicano, y posteriormente, a un haitiano. Finalmente, la investigación desveló que la muerte de la niña había sido un accidente.

Las noticias de las desapariciones y crímenes alcanzaron gran popularidad, extendiendo el pánico entre la población e incriminando a los brujos y a los haitianos de utilizar a menores blancos en los ritos, en algunos de los cuales también se comentaba se comían algunas partes de sus cuerpos y bebían su sangre. Así mismo, cada noticia alimentó las leyendas y los miedos que durante años habían alimentado el imaginario cultural y el perjuicio racial (Chávez, 1991). Las noticias y rumores de secuestros, intentos de secuestros y asesinatos de los que se inculpó a la población afrodescendiente condujo al linchamiento de algunos acusados. Estas acusaciones y agresiones fueron contestadas desde algunos periódicos, como El Mundo, en julio de 1919, y por las sociedades de color (Pérez de la Riva, 1979, t. 2, pp. 63-65).

Algunos de estos hechos fueron examinados a la luz de la ciencia. El dictamen del crimen de la niña Zoila por el antropólogo y jurista Fernando Ortiz aparece en su libro Hampa Afro-cubana: Los Negros Brujos, el primero de la trilogía dedicada a la población esclavizada africana, publicado en 1906. En esa fecha, siguiendo las teorías de la Escuela Criminológica de Cesare Lombroso, Ortiz propuso que se prohibiera practicar las religiones afrocubanas, que los brujos fueran apresados para aislarles de la sociedad, y se confiscasen todos los objetos, como los tambores, que se utilizaban en estos ritos. En este libro, donde Ortiz reproduce los artículos sobre secuestros, crímenes, sacrificio de animales o profanación de tumbas que fueron publicados en la prensa cubana, explicó con detalles el crimen de la niña Zoila, incriminó a algunos de los practicantes de las religiones afrocubanas (de manera especial a los brujos), y, lo que es más interesante para nuestro estudio, comentó el carácter maléfico de la brujería haitiana o la jamaicana que, en su opinión 
Inmigrantes antillanos en Cuba: discursos económicos, raciales e identitarios, 1910-1940

era superior a la practicada por los brujos cubanos, y la práctica frecuente de envenenar entre los afroantillanos. Con estas consideraciones se ponía una piedra más en la construcción de un mito alrededor de la religión de los haitianos; su vinculación a la brujería fue un peldaño más en la formación del imaginario antinegro y antihaitiano que entrañaba barbarie, peligro y miedo. De este modo se refería Ortiz a los secuestros y asesinatos de los niños blancos en los campos de Cuba

donde la acción del poder social es casi nula, donde hay negros que viven de modo verdaderamente africano, no es de extrañar que el fetichismo haya conservado todos sus caracteres de barbarie primitiva, sin haber avanzado un solo paso en la evolución de las ideas religiosas y, en general, de la inteligencia [...] Pero ello no basta para atribuir a la brujería afrocubana el carácter de delincuente en el grado que son consideradas las de Haití, Jamaica, etc. (Ortiz, 1917, pp. 170-172).

\section{Los últimos años de la inmigración antillana: las repatriaciones de los haitianos}

En algunos informes consulares de Cuba en Haití se indicaba que el número de haitianos en Cuba era de unos 238.000 en 1922. En esta cifra estaban incluidos los 94.000 braceros que habían salido de manera legal desde Aux-Cayes entre 1918 y 1922, 94.000 que viajaron de manera ilegal y un promedio de 50.000 niños nacidos en Cuba. ${ }^{14}$ Como vamos a ver en las siguientes páginas, las crisis económicas de 1921 y 1929 marcaron el final de esta migración, a la vez que reanimaron la polémica sobre los beneficios y daños que representaban para la sociedad cubana.

Al fin de la "Danza de los Millones" en 1921, algunas disposiciones legales frenaron la llegada de inmigrantes. El Decreto núm. 1.158 limitó la entrada a quienes tuvieran contrato, dejó solo dos puertos habilitados para el desembarco de inmigrantes, el de La Habana y el de Santiago de Cuba, y autorizó la repatriación de los haitianos y jamaicanos que hubiesen sido introducidos por la Ley de 1917. A partir de este año, el flujo

14. Informe del agente consular de Cuba en Port-aux-Prince, Felipe Torres. ANC, Fondo Secretaría de Estado, leg. 213, exp. 2728. 
de la migración haitiana tuvo grandes oscilaciones y aunque volvió a aumentar a partir de 1924 nunca alcanzó los niveles anteriores. Un ejemplo del plan de contratación de estos braceros es la solicitud de H. C. Lakin, presidente de la Cuban Company, para introducir 1.000 braceros haitianos, el 9 de febrero de 1923. Su destino era el central Jobabo, perteneciente a dicha compañía, situado en la provincia de Oriente, actualmente provincia de Las Tunas. En este central, que comenzó a ser construido en 1908, trabajaron obreros de distinta procedencia: españoles, cubanos, jamaicanos, haitianos y chinos.

En el plan presentado por Lakin, los haitianos serían reclutados en Haití y conducidos al puerto de Nuevitas. La compañía asumiría la fianza que se señalase para asegurar el regreso de los trabajadores a Haití, y se comprometía a reembarcarlos a su país al día siguiente de finalizar la zafra. A los pocos días, el 16 de febrero, el presidente de la compañía recibió una carta en la que se le comunicaba la concesión del permiso. El 6 de octubre de 1923, la Compañía informó que no había contratado a los haitianos, ya que la zafra de ese año pudieron hacerla con mano de obra local, por lo que unos meses después, el 19 de marzo de 1924, solicitó la devolución de la fianza que había depositado para su introducción, que ascendía a 5.500 pesos. Aunque el plan no se llevó a cabo, es interesante conocer cómo se reguló la introducción de trabajadores contenidas en el Decreto núm. 235, publicado el 22 de febrero de 1923, que aseguraban al Estado cubano que la Cuban Company era la única responsable tanto del traslado de los trabajadores como de su estancia en Cuba y de su regreso a Haití. ${ }^{15}$ Las condiciones eran las siguientes:

- los trabajadores tenían que ser hombres experimentados en el trabajo agrícola o industrial con relación al cultivo de la caña y elaboración del azúcar;

- estaba obligada a reembarcarlos a su país de origen en el momento en que terminasen los trabajos para los que fueron contratados;

- abonaría a los trabajadores los jornales establecidos en la provincia de Oriente; 
Inmigrantes antillanos en Cuba: discursos económicos, raciales e identitarios, 1910-1940

- les proveería servicio médico y medicinas si enfermaran en Cuba, además de asegurarles por si enfermasen;

- entregaría una fianza de 20.000 pesos por cada trabajador para cubrir los posibles gastos de reembarque si el gobierno tuviera que hacerlo;

- enviaría una relación nominal de todos los trabajadores importados que debería estar legalizada por el administrador de la Aduana de Nuevitas, e iguales relaciones legalizadas en los puertos de desembarque y visadas por el representante consular de Cuba en el puerto de desembarque.

En 1928, el Gobierno de Haití prohibió por unos meses la emigración a Cuba. Tras esta decisión pesaron algunas denuncias interpuestas por el representante diplomático de Haití en La Habana por el maltrato dado a algunos compatriotas. En esta ocasión las protestas las suscitó el trato desigual que recibían los presos haitianos; en otras, eran denuncias por muertes acaecidas en algunos ingenios. En varios momentos del año 1928, el 30 de agosto, 14, 16 y 29 de septiembre y 3 de octubre de ese año, la legación haitiana en Cuba se quejó oficialmente ante el Gobierno por la situación de los haitianos presos en La Habana y en Ciego de Ávila, considerando que las medidas que se tomaban únicamente contra ellos tenían un carácter racial y xenófobo. El 30 de agosto 1928, el ministro de Haití informaba al secretario de Estado de Cuba que en la cárcel de Ciego de Ávila había haitianos que no habían sido juzgados ni sentenciados, y que los que ya habían sido juzgados estaban sometidos a trabajos forzosos sin que esto estuviera contemplado en la sentencia. Tras la protesta del diplomático, se abrió ese mismo día una investigación en La Habana y en Ciego de Ávila, al frente de la cual se puso al jefe de Policía Nacional. El 16 de septiembre el capitán de la Guardia Rural de Ciego de Ávila y delegado de la Sección de Gobernación informó que no se estaba incurriendo en una ilegalidad, ya que la sentencia era similar para presos españoles, cubanos y de otras nacionalidades. A similares conclusiones llegó el jefe de Policía Nacional en su informe del 29 de septiembre. ${ }^{16}$ La presión de las compañías azucareras y de los sectores que actuaban como intermediarios en la entrada de braceros

16. ANC, Fondo Secretaría de la Presidencia, Caja 44, exp. 32. 
condujo a que, a finales de 1928, los Gobiernos de Cuba y Haití firmaran un acuerdo para su entrada en Cuba.

Los jornaleros haitianos fueron en estos años la principal mano de obra en el campo. Se desplazaban por las provincias de Camagüey y Oriente en función del calendario agrícola del corte de arroz en Manzanillo y de las cosechas de azúcar y de café, cultivado en la parte suroriental, en la Sierra Maestra y de Yateras, en donde eran el principal recurso del que disponían los cafetaleros para hacer este trabajo. La crisis de 1929 afectó a esta migración. En los años siguientes, las entradas fueron descendiendo. En la década de 1930 se calcula que trabajaban en Cuba entre 150.000 y 200.000 antillanos (Knight, 1985). El censo de 1931 arroja la cifra de 103.540 antillanos residentes de manera legal en la isla, de los cuales cerca del 50\% estaban en la parte oriental, alrededor de los grandes centrales azucareros a los que habían venido a trabajar. De ellos, 77.535 habían nacido en Haití, mientras que los inmigrantes procedentes del Caribe británico eran 28.206. El peso desigual de ambas comunidades marcó también las diferencias en las deportaciones, especialmente en su volumen (Giovannetti-Torres, 2018, p. 71). En 1931 el médico eugenista, presidente de la Academia de Ciencias y miembro de la Cámara de Representantes, Francisco María Fernández, elaboró un proyecto para suspender la inmigración por dos años, sin distinción de edad, sexo y nacionalidad. ${ }^{17}$ Aunque el proyecto no fue aprobado, la situación económica del país motivó que el gobierno intensificase las medidas que limitaban la inmigración en general y sobre todo clandestina. A través de distintos decretos se pusieron en vigor algunas condiciones entre las que cabe destacar las siguientes: el registro de los barcos a la llegada por los jefes de los puertos para detectar a los inmigrantes clandestinos, que los inmigrantes supieran leer y escribir en castellano, así como que los menores de veintiún años poseyeran entre su documentación la autorización para emigrar expedida por las autoridades de su país, la prohibición de entrada a los individuos mayores de cincuenta y cinco años, entre otras. Sin embargo, dichas medidas, si bien limitaron las entradas, no impidieron el arribo de inmigrantes hasta fines de la década de 1930, aunque en un número mucho más reducido que en los años anteriores.

17. Archivo del Ministerio de Asuntos Exteriores, Madrid, R. 943, exp. 43. 
Inmigrantes antillanos en Cuba: discursos económicos, raciales e identitarios, 1910-1940

En estos años, la correspondencia entre el Gobierno haitiano y sus representantes en Cuba con las autoridades de Cuba fue abundante. Las denuncias de asesinatos de haitianos dan paso según avanzaba la década de 1930 a informes sobre las repatriaciones y el maltrato que recibían mientras esperaban embarcar. ${ }^{18}$

Uno de los informes relata la muerte de Nervilus Pierrus, conocido como “Nicolás Simón”, el 13 de enero de 1932, en el batey de la Grua, en el central Miranda, en Santiago de Cuba, donde frecuentaba a dos mujeres cubanas, madre e hija, que se dedicaban a la prostitución clandestina. Los hechos fueron denunciados por un vecino con la acusación de "atentar contra la honradez". Tras personarse el policía, llamado Bolaños, en el batey y preguntarle qué hacía allí, el haitiano le contestó de mala manera, arrancándole el machete e intentó hacer lo mismo con la pistola, por lo que el policía disparó y el haitiano murió. La acusación de homicidio fue sobreseída. Igual pasó con la protesta por la muerte de un haitiano que Ernest Rigaud, representante de Haití en Cuba, envió al gobierno de Cuba el 8 de abril de 1932. El expediente remite al 3 de abril en el barrio Canales, donde estaba el central Pilar, en el poblado Gaspar, en Ciego de Ávila, donde murió un haitiano como consecuencia de un disparo. El origen del altercado lo había provocado el pago de una apuesta en la pelea de gallos en la que estaban implicados, el haitiano y otro individuo llamado "Boche", que tras ganar reclamó al haitiano su dinero. Según decía otro testigo, el haitiano llevaba una pistola. Un policía presente llamado Rondón trató de sujetar al haitiano que, tras salir corriendo, se dio la vuelta y sacó un cuchillo en forma de puñal. Según Boche, el policía, para defenderse tuvo que dispararle dos veces. Varios testigos confirmaron su declaración. Otro de los presentes declaró que el haitiano nunca reconocía las apuestas cuando perdía, así como que el policía fue quien disparó tras ver que el haitiano sacaba un cuchillo. El informe remitido concluía diciendo que el policía había sido acusado de homicidio y estaba en prisión a la espera de juicio.

Aunque las causas abiertas no pudieron probar que el apresamiento o muerte de algunos haitianos eran consecuencia de xenofobia o de racismo, los informes detallados de la policía dejaban constancia de lo que

18. ANC, Fondo Secretaría de Estado, leg. 495, exp. 11176. 
llamaban "la vida desordenada que llevaban los haitianos", la actitud violenta de muchos contra la guardia rural y el celo policial.

La presencia de antillanos en Cuba disminuyó drásticamente tras promulgarse el decreto de expulsión de los trabajadores desocupados y la Ley de Nacionalización del Trabajo o Ley del 50\% en 1933, contenida en el Decreto núm. 223. Esta ley estableció que en todos los trabajos debía haber al menos 50\% de nativos, además de autorizar la repatriación forzosa, a cuenta del Estado, de los extranjeros sin trabajo que no contasen con algún tipo de recurso, a quienes se les entregaría $200 \$$. A partir de ese año, miles de haitianos fueron repatriados. ${ }^{19}$ En este proceso trágico y en ocasiones doloroso, muchos haitianos no encontraron protección de su gobierno. En ocasiones, los cónsules, al igual que los empleados cubanos de las aduanas, se beneficiaron tanto de la introducción de inmigrantes como de su repatriación. Los braceros la mayoría de las veces no contaban con recursos para obtener los documentos que se les exigían para regresar a su país, por lo que tenían que aceptar la mediación y el chantaje de quienes les podían ayudar a conseguirlos a menor precio.

En 1934, para saber qué medidas tenían que adoptarse para el reembarque de haitianos y jamaicanos, el Gobierno envió a Oriente y Camagüey al economista y abogado Rogelio Pina y Estrada, a fin de tener una información actualizada de su número y de su situación legal. Tras visitar las comarcas azucareras y cafetalera de Camagüey y Oriente, y recoger testimonios de las distintas clases sociales, que eran a veces contradictorios, Rogelio Pina y Estrada remitió un informe detallado el 29 de junio de 1934 al presidente de la República y al consejo de secretarios. ${ }^{20}$ En él se detenía en la distinta apreciación que del problema tenían, por una parte, de los obreros y campesinos, y, por otra, los hacendados, grandes propietarios y colonos. Mientras que los obreros y campesinos pensaban que los braceros antillanos debían ser repatriados sin demora por no ser útiles al país ni indispensables para la recolección de frutos, los hacendados, grandes propietarios y colonos, sin negar los inconvenientes de esta inmigración y las ventajas de su supresión, sostenían que era indispensable que permanecieran en Cuba. Además, aseguraban que su reembarque haría 
imposible que se efectuara la siguiente zafra, al no existir otros brazos para este trabajo, especialmente para el corte y levantamiento de la caña.

En opinión de Rogelio Pina y Estrada, era preciso conciliar ambos intereses y no apoyar a los segundos, en un país depauperado por su defectuosa estructura económica, agravada por la política económica de Estados Unidos. Por otra parte, el problema de la contratación de antillanos respondía al escaso valor del azúcar, que en esos momentos era menor de 1 centavo y medio por libra, por lo que los cubanos no trabajaban en el campo en Oriente, relativamente despoblado y en donde se cultivaba más de la mitad del azúcar de Cuba. Para evitar esto, era preciso subir el jornal ya que cuando el corte de caña se pagó a 45 centavos las 100 arrobas, el número de braceros cubanos había aumentado, como había sucedido en el central Jaronú, localizado en Camagüey.

En el informe, en el que utilizaba términos como "mejoramiento étnico" o "invasión antillana", retrotrayéndose en el tiempo, aludía a las leyes de inmigración que velaban por la entrada de inmigrantes indeseables y castigar a sus infractores como la ley de inmigración de 1902, núm. 155. De haberse mantenido este reglamento, Rogelio Pina Estrada comentaba que no habrían entrado los millares de haitianos y jamaicanos que llegaron. También se lamentaba de que no se hubiera continuado con la política migratoria de los años siguientes que privilegiaba la entrada de braceros de Suecia, Noruega, Dinamarca y norte de Italia; "es una pena — decía- que no se haya cumplido todavía ya que de esa manera no habrían entrado los braceros antillanos". Calificaba de "invasión" la llegada de antillanos que se produjo tras 1917 y el incumplimiento de las normas que habían permitido la entrada de antillanos que constituían la llamada "inmigración indeseable" al encontrarse fuera de la ley, así como la entrada de chinos "en su mayor parte analfabetos y casi indigentes, que disputan al nacional los medios de vida, desvalorizando la mano de obra, cuando sería tarea muy fácil y legal la de expulsarlos de un país en el que entraron por fraude". Según él, la violación de las leyes sobre inmigración era una causa suficiente para declararlos ilegales y proceder a su repatriación.

En el informe establecía diferencias entre los haitianos y los jamaicanos, a quienes consideraba más cultos, ya que la mayoría sabían leer y escribir, además de no dedicarse al corte de caña, objeto principal de su introducción, por lo cual los hacendados no se oponían mayoritariamente 
a su inmediato reembarque. Los jamaicanos vivían de distintas artes manuales, sus mujeres eran criadas y algunos, hasta profesores, es decir competían en las ciudades con el español, el isleño (canario) y el cubano. Así mismo, indicaba que tenían más apoyo al ser súbditos ingleses, al extremo que los funcionarios de Inmigración y los soldados del Ejército tras la Ley de 1933, se limitan a capturar y repatriar a los haitianos.

Para justificar la repatriación de los haitianos, Rogelio Pina recurrió a los argumentos económicos, sociales, raciales y culturales que se emplearon contra ellos desde que comenzaron a llegar al país: disputaban el trabajo al obrero nacional, al que depreciaban desmedidamente; tenían baja moralidad y eran portadores de enfermedades y vicios que constituían una "indudable amenaza" para Cuba. La "amenaza" era aún mayor en medio de una crisis económica mundial. En su opinión, el inmigrante blanco seguía siendo el más apto para el país, por lo que, en el momento en que se recuperara de la crisis:

[...] podrían contratarse de nuevo braceros blancos europeos y canarios y de otros países de esa raza [...] para que nuestra tierra pueda completar el ciclo evolutivo que en menos de un siglo elevó nuestra población blanca desde el $41 \%$ que era en 1841 al 71\% de la total población, según el censo de 1919.

Si se hubiese privilegiado la entrada de inmigrantes blancos, Cuba sería blanca ya que absorbería a la negra en virtud de una especie de instinto biológico-social que no se observa en otras latitudes ni en la raza anglosajona, fenómeno que, si bien por algunos podría considerarse un vicio o defecto de moralidad personal, no deja de constituir hasta cierto punto una cualidad étnica si se tienen en cuenta intereses futuros de Cuba.

Y para no dejar duda de las consecuencias negativas de la inmigración antillana, Rogelio Pina comentaba la evolución de la población blanca, cuyo número se había reducido sobre todo en Camagüey y Oriente. Siguiendo el censo de 1931, apuntaba que en Camagüey, con 408.076 habitantes, $72 \%$ eran blancos, y $28 \%$ negros, mestizos y chinos. Allí residían 31.992 nacidos en Haití y 11.088 de nacionalidad inglesa, casi todos jamaicanos, un total de 43.080, por lo que, de no haber llegado los antillanos, la población no blanca en esta provincia representaría el 16\%. En la 
Inmigrantes antillanos en Cuba: discursos económicos, raciales e identitarios, 1910-1940

provincia de Oriente, con 1.072 .757 habitantes, 57\% eran blancos y 43\% eran negros, mestizos y chinos. Allí residían 42.988 nacidos en Haití y 17.472 de nacionalidad inglesa, un total de 60.460 antillanos. Como en el caso de Camagüey, si no hubiera llegado esta inmigración antillana, la población no blanca sería algo menor del 37\%. En esta provincia, en Holguín, de 127.443 habitantes, 107.324 eran blancos y 20.119 negros, mestizos y chinos. Allí vivían 4.048 haitianos y jamaicanos. Si estos no hubiesen entrado, la población negra se reduciría y representaría menos del 13\%. Aunque, según el censo de 1931, los haitianos y jamaicanos ascendían a 103.540, Rogelio Pina llamaba la atención sobre esta cifra al considerar que su número era mayor, ya que había ocultaciones y desembarques clandestinos.

Aconsejaba que se prohibiera la inmigración negra y china, y que esta inmigración se fuera sustituyendo por braceros cubanos, españoles e isleños; además que los dueños de ingenios y cafetales pagasen mejores salarios, que subirían tras recuperarse la economía, y ofrecieran mejores condiciones en los alojamientos. Así mismo, proponía que los trabajadores que se trajeran de otras provincias constituyeran colonias agrícolas de modo similar al proyecto de la United Fruit Company, dueña de los centrales Preston y Boston, (1928-1930), que, en colaboración con el Gobierno, trajo de las provincias occidentales varias familias, un total de 14.299 personas, 4.405 adultos y 3.256 menores de 15 años. Estos fueron alojados en una zona cerca al manantial de Guaro, en 1.700 casas construidas con techo de guano y paredes de bagazo y barro en su mayoría. A cada familia se le dio un pequeño lote de tierra para cultivo. El sistema no era el del colono que sembraba su caña y la llevaba a moler, sino el de la siembra para la administración. Aunque el sistema había sido un éxito, señalaba que varios miles de haitianos cortaban caña en ambos centrales.

Según Rogelio Pina, la colonización tendría mayores dificultades en Oriente, en la zona situada entre Holguín, Bayamo y Palma Soriano, donde estaban los grandes centrales Palma, Báguanos, Tacajó y San Germán. Una zona difícil para el asentamiento de población por la carencia de agua. La mejor manera de llevarla a cabo era que los dueños de los centrales azucareros se pusieran de acuerdo con la Asociación de Colonos para atraer campesinos de Cuba y darles buenas condiciones en su alojamiento, así como y un terreno para cultivar. Dadas las restricciones de 
la producción de azúcar impuestas por Estados Unidos (3 millones de toneladas), no sería necesaria la contratación de antillanos.

El informe terminaba con una serie de recomendaciones sobre la inmigración que debía promover y aceptar Cuba, algunas de las cuales aparecen a lo largo del escrito, y sobre el modo de proceder con las repatriaciones. Entre las medidas que el Gobierno debía tomar se encontraban prohibir la inmigración de negros y chinos; aceptar solo la inmigración de población blanca, preferentemente por familias; repatriar a los antillanos indigentes y sin trabajo o que estuvieran ilegales; hacer la repatriación de manera escalonada y organizada de acuerdo con los propietarios, procurándose que los antillanos fuesen remplazados por trabajadores nacionales; repatriar de manera inmediata a los antillanos hospitalizados o encarcelados, que estimaba en unos 1.000; hacer un censo de inmigrantes antillanos; elaborar un plan con las asociaciones de hacendados para llevar trabajadores de otras zonas del país proporcionándoles alojamiento, higiene y un lote de tierra; dictar leyes contra la vagancia en los campos para que desaparecieran el espectáculo de la venta de lotería, así como mendigos o personas que estuviesen vendiendo sus trabajo a la bastarda política; que los reembarques se realizaran en mayor cantidad y en el menor tiempo posible, comenzando por los indigentes y enfermos, para seguir los solteros, y luego las familias; que se dispusiera de un fondo para la recogida de antillanos y su conducción al puerto, así como de un buque encargado solo de la repatriación. En el caso de los jamaicanos, debía tenerse en cuenta que casi todos dieron una fianza a las compañías de vapores que los trajeron a Cuba para responder a su reembarque, por lo que los gastos quedarían cubiertos con dicha fianza. Así mismo, recomendaba que se calculase si el aumento del valor del azúcar haría posible disponer de maquinaria para el corte de caña; disponer que la zafra comenzara en los ingenios libremente y que durase por lo menos 100 días, y aumentar la vigilancia y el personal de inmigración en Oriente, para impedir desembarcos clandestinos.

El dictamen de Rogelio Pina Estrada no podía ser más contrario a los braceros antillanos, cuya repatriación debería comenzar el 8 de noviembre de 1933. Sus indicaciones fueron seguidas por las autoridades que, a finales de 1933, comenzaron a repatriarlos. El 25 de mayo de 1934, se habían repatriado 5.907 haitianos, número que en junio ascendía a casi 
Inmigrantes antillanos en Cuba: discursos económicos, raciales e identitarios, 1910-1940

8.000. Durante los años en que hubo las repatriaciones, el representante diplomático de Haití en Cuba expresó en distintos momentos su inquietud por el elevado número de haitianos que residían en el país y por la forma en que se hacían dichas repatriaciones. En febrero de 1936, el ministro de Haití en Cuba, Ernest Rigaud, mostraba su preocupación al secretario de Estado de este país por la suerte que correrían los 50.000 haitianos residentes, a la vez que solicitó que no se multase a aquellos que en 1935 no se inscribieron en el Registro de Inscripción de Extranjeros residentes en Cuba. En su carta llama la atención del político cubano sobre los haitianos que, tras permanecer un año y un día en la cárcel, aún se encontraban detenidos, se quejaba de que los trabajadores del campo eran maltratados por los guardias rurales y pedía que las autoridades les protegieran al igual que hacían las autoridades de Haití con los cubanos residentes en su país. ${ }^{21}$

Las expulsiones comenzaron tras la publicación en enero de 1937 del Decreto-ley núm. 282 y las resoluciones número 17 y 24 del secretario de Trabajo de Cuba, publicados en la Gaceta Oficial el 21 de enero y el 4 y 6 de febrero de 1937. Aunque unos meses antes se les había dicho que las leyes no se aplicarían a los trabajadores que residieran en Cuba por un tiempo considerable, las medidas afectaron a trabajadores de distintas nacionalidades. Junto a los haitianos y jamaicanos más de 300 trabajadores de Curaçao perdieron el trabajo. ${ }^{22}$ Para hablar sobre estas medidas e impedir el reembarque, se desplazó a Cuba el jefe de inspectores $\mathrm{H}$. Meersma, en abril de 1937. El 4 de octubre, el Gobierno holandés reclamó al cubano el dinero pagado por las repatriaciones, 9.020,27 guilders (florines neerlandeses), a lo que el Gobierno cubano respondió diciendo que no tenía obligación de pagar nada y que esos trabajadores estaban de manera ilegal en el país, que el Gobierno no solicitó su entrada ni los introdujo. Su admisión fue puntual y destinada a trabajar en las zafras de 1917 y posteriores, con el propósito de reintegrarlos a sus países por su propia cuenta o la empresa que los contrató.

Las reclamaciones mantuvieron muy activas a las legaciones diplomáticas en Cuba, de manera particular la de Haití. El 22 de enero, el

21. ANC, Fondo Secretaría de Estado, leg. 424, exp. 8977.

22. ANC, Fondo Secretaría de Estado, leg. 213, exp. 2714. 
ministro plenipotenciario, a la vista de la información proporcionada por los cónsules y agentes de Haití en Cuba, trasladaba su inquietud al secretario de Estado de Cuba, Luis Miranda, por la crítica situación de los trabajadores haitianos afectados por el plan de repatriación propuesto por el secretario del Trabajo, y le solicitaba que mediase ante los propietarios de los ingenios. ${ }^{23}$ En esta carta le explicaba que los haitianos eran separados de sus trabajos y de sus familias y sufrían ataques violentos. Esta situación provocó que centenares de haitianos acudiesen a los consulados de Santiago de Cuba y Camagüey para saber qué podían hacer y cuál era su futuro. Las peticiones y protestas de los representantes diplomáticos fueron escuchadas, actuando de inmediato, al menos oficialmente. ${ }^{24} \mathrm{El} 25$ de enero, el secretario del Trabajo le contestó de manera evasiva diciendo que, al no especificar datos concretos de la situación, no se podía hacer nada. Unos días después, el 29 de enero de 1937, el secretario de Trabajo, J.M. Portuondo, salía al paso de la supuesta violencia utilizada contra los haitianos diciendo que su intención no era atropellar a ningún nacional de cualquier país, sino terminar con la situación ilegal y la permanencia en suelo cubano de trabajadores ilegales, que entraron a trabajar solo por un tiempo determinado, y dado que las medidas de repatriación no se habían puesto en marcha era imposible que hubiesen afectado a un grupo de trabajadores haitianos. Además, aseguraba que cuando se comenzara a sustituir extranjeros por cubanos, se haría según la Ley de Nacionalización, de modo gradual y sin violencia, e invitaba a los cónsules a ser observadores del proceso.

El secretario de Trabajo también atendió la petición de ministro plenipotenciario de Haití de interceder ante los hacendados. A los pocos días, el 10 de febrero de 1937, Miguel Perdomo Peñate —capitán del Ejército constitucional, delegado de la Secretaría de Trabajo y responsable para llevar a cabo las repatriaciones de antillanos que realizaban labores de zafra-, remitió una carta circular a los hacendados, colonos, administradores de ingenios y antillanos residentes en la provincia de Oriente, en la que avisaba que no permitiría que se cometieran injusticias contra los inmigrantes laboriosos mientras eran repatriados; que velaría por todos los intereses

23. ANC, Fondo Secretaría de Estado, leg. 213, exp. 2726.

24. Id. 
Inmigrantes antillanos en Cuba: discursos económicos, raciales e identitarios, 1910-1940

en este proceso, "cubanísima obra" de proteger a los trabajadores cubanos; que el Ejército constitucional era el responsable de la repatriación, por lo que los antillanos no serían embarcados de manera impropia, que:

[...] por imperativo categórico de las circunstancias económicas que nos agobian se ven impelidos a regresar de nuevo a sus hogares, donde tal vez les esperen miserias y estrecheces dolorosas, que sus gobernantes tratarán de aliviar, como tratamos nosotros de aliviar las de nuestros con-nativos, resolviendo el problema básico del desempleo [...]

... y que ningún antillano sería retirado de su trabajo mientras ese puesto no lo quisiera un cubano apto física y moralmente capaz de sustituirle. Como las quejas continuaron, Perdomo adoptó una posición más firme en la siguiente carta circular, en la que prevenía a todos los que obrasen de mala fe contra los antillanos y que no cumplieran los contratos pendientes, que serían acusados ante los tribunales de justicia. También les decía a los antillanos que para ser repatriados no tenían que esperar a que las autoridades les requiriesen que se anotasen, sino que podían inscribirse en las horas y días hábiles en las oficinas de la delegación provincial de la secretaría de Trabajo, y les aseguraba que nadie sería repatriado sin saldarle las cuentas.

Como prueba del buen trato que recibían los haitianos en los campamentos antes de ser repatriados, Miguel Perdomo Peñate incluyó en su informe el menú que se les daba en el Campamento del Campo de Tiro, del 10 de febrero de 1937, consistente en un desayuno, con café y pan; el almuerzo, donde se servía potaje, arroz banco, ropa vieja, pan y café (lunes) que iba variando en vez de ropa vieja carne entomatada, carne con papa, o carne, o el jueves: congrí oriental, sardinas, viandas, pan y café; y la comida (cena) a base de congrí oriental, arenques, viandas, pan y café (lunes), y otras veces, en lugar de arenques, vaca frita o carne, o, en lugar de congrí oriental, arroz blanco o potaje. ${ }^{25}$

Pero las noticias procedentes de las provincias donde residían los haitianos seguían siendo alarmantes. A finales de febrero de 1937, el cónsul de Haití en Santiago de Cuba informó al ministro plenipotenciario, Justin Barau, sobre la forma en que los haitianos eran recogidos en los campos

25. ANC, Fondo Secretaría de Estado, leg. 213, exp. 2726. 
y custodiados hasta puestos militares, a los que otras veces se refería como campos de concentración, en donde permanecían entre 4 y 5 días antes de embarcarlos a Santiago, sin darles de comer y sin devolverles los impuestos que pagaron por adelantado al anotarse en el Registro de Extranjeros en 1937. Justin Barau trasladó de nuevo la protesta al secretario de Estado el 25 de febrero, denunciando, además, que los haitianos eran maltratados, y no así los jamiacanos, lo cual atribuía a su condición de ingleses coloniales. La respuesta inmediata de las autoridades cubanas abundaba en que la repatriación se haría observando toda la seguridad en el empeño de mantener las buenas relaciones entre ambos países. Parece que las palabras del diplomático haitiano sobre el desigual trato que recibieron los haitianos y los jamaicanos eran ciertas. En una nota publicada en un periódico de Jamaica, el secretario colonial inglés decía que solo los haitianos eran concentrados en campos especiales para esperar la repatriación. En la misma mencionaba la repatriación de unos 40.000 jamiacanos debido al elevado desempleo entre los nativos de Cuba. ${ }^{26}$

La prensa extranjera se hizo eco de lo que estaba ocurriendo en Cuba, más aún tras anunciar Fulgencio Batista, jefe de las Fuerzas Armadas, que al terminar la zafra azucarera de 1937 expulsó a más de 50.000 haitianos y jamaicanos, y que para ello ya se habían finalizado las negociaciones diplomáticas. La Tribuna italiana D’America, el 12 de febrero de 1937, incluía una noticia sobre las repatriaciones, haciendo hincapié en las consecuencias negativas que la migración de braceros había producido en Cuba: "Desde hace más de 20 años ha habido una invasión de negros en Cuba desde las islas vecinas, especialmente de Haití y Jamaica". Comentaba que su presencia había bajado los salarios para los nativos en Cuba en los campos de caña, y que Batista había encontrado la forma de deshacerse de este trabajo barato. ${ }^{27}$

Comenzadas las repatriaciones, en febrero de 1937, surgieron distintos problemas que fueron motivo de conflicto y de reclamaciones. Uno de ellos fue la negativa de algunos haitianos del ingenio Siboney, de la Compañía Azucarera Najasa S. A., a pagar el carnet de extranjero, aconsejados por el cónsul de Haití en Camagüey. La cuestión se trasladó al secretario de 
Inmigrantes antillanos en Cuba: discursos económicos, raciales e identitarios, 1910-1940

Estado el 27 de marzo de 1937, para saber si a los haitianos que regresaban a su país se les debía descontar del salario el importe del carnet de extranjero. ${ }^{28}$ Otro problema lo suscitó el pago a los haitianos de las cantidades adeudadas. El 15 de febrero, Justin Barau escribía al secretario de Estado, esta vez preocupándose por el pago a los haitianos de las cantidades que se les adeudaba antes de ser repatriados. De manera concreta se refería a los haitianos que trabajaban en los distritos cafetaleros en carácter de colonos partidarios dividiendo el producto de las tierras que cultivaban con los propietarios, y cuya calidad de colonos partidarios estaba acreditada con los certificados que poseían. ${ }^{29} \mathrm{El} 6$ de mayo, el diplomático solicitaba que se diferenciase entre los braceros cortadores de caña y los haitianos que residían en el país hacía 10, 15 o 20 años y que tenían plantaciones de café y para quienes pedía se les diera más tiempo para liquidar sus propiedades, ya que Perdomo obligaba a todos a recoger sus pertenencias y no tenía en cuenta los certificados de ser colonos. El secretario de Estado le contestó diciendo que él o el cónsul en Santiago les indicarían quiénes eran los colonos y que le remitieran caso por caso para estudiarlo, asegurándole que los colonos serían dejados para los últimos embarques. Dado que los embarques habían comenzado en febrero de 1937, y estimándose que durarían entre 6 meses y 1 año, los colonos tendrán tiempo para liquidar los bienes. ${ }^{30}$

Sobre las condiciones del reclutamiento de los haitianos en campamentos, el Gobierno de Cuba informaba, el 25 de febrero de 1937, que todas las concentraciones habían sido voluntarias por encontrarse sin trabajo y para aprovechar la oportunidad que les brindaba el gobierno de Cuba. Desde el campo eran enviados en tren a Santiago, desde donde se trasladaban en camiones a los campamentos o campos de concentración, donde se inscribían y permanecían hasta ser conducidos al puerto. En todo momento los haitianos recibían un buen trato, como lo podía atestiguar el delegado del Gobierno de Haití que había en cada campamento. ${ }^{31}$

El 2 de marzo de 1937, Justin Barau solicitó al subsecretario de Estado de Cuba, Miguel Ángel de la Campa, negociar la firma de un acuerdo

28. ANC, Fondo Secretaría de Estado, leg. 213, exp. 2729.

29. ANC, Fondo Secretaría de Estado, leg. 213, exp. 2726.

30. ANC, Fondo Secretaría de Estado, leg. 213, exp. 2728.

31. ANC, Fondo Secretaría de Estado, leg. 213, exp. 2727. 
para la repatriación de haitianos en el que se especificase la fecha y ritmo de las salidas, con el fin de que el Gobierno de Haití pudiera absorber sin dificultad una cantidad tan grande de repatriados. Ese mismo día, Miguel Ángel de la Campa envió un memorándum al Gobierno de Haití en el que comunicaba que las condiciones de Cuba obligaban a proceder a la repatriación y que la naviera había confirmado que los barcos cubanos transportarían entre 500 y 1.500 en cada viaje; igualmente, le decía que los oficiales de las Fuerzas Armadas en Santiago y en Camagüey velarían por que los haitianos fueran tratados con todo respeto.

Las quejas por malos tratos fueron constantes. El 5 de marzo de 1937 el ministro plenipotenciario de la República de Haití en La Habana denunció en nota verbal al subsecretario de Estado de Cuba que los obreros haitianos eran "acorralados como animales, son saqueados en presencia de los soldados llamados a darles protección; llevados a campamentos de concentración, sufren toda clase de privaciones, extendiéndose también estos medios a las mujeres, a los niños y hasta aquellos que no son emigrantes." Ante esta violencia e indefensión, reclamaba que las autoridades de Cuba les protegieran. Además, insistía en que la repatriación se realizara tras firmar un acuerdo entre ambos, y que no admitía que se hiciera solo mediante un aviso de 24 horas. Advertía al Gobierno cubano que, de seguir así la situación, se verían obligados a asumir la misma actitud con los ciudadanos cubanos residentes en Haití que gozaban de la protección del Gobierno. Dirigiéndose a los representantes de Haití en Cuba, les ordenaba no expedir más certificados con la exención de los 2 dólares, ni conceder la autorización correspondiente a los barcos salientes. El 9 de marzo, el Gobierno cubano contestó de forma muy amigable diciendo que seguiría ejerciendo su derecho para proteger a sus connacionales cubanos; que agradecería cualquier sugerencia que el gobierno haitiano les hiciera en beneficio de los repatriados haitianos, a quienes reconocía su trabajo en Cuba; que había comprobado que no existiesen malos tratos y que, en caso de suceder, los infractores serían castigados. En el mismo escrito explicaban que, aunque era imposible firmar un acuerdo, el Gobierno de Cuba informaría con antelación de los embarques a través de su encargado de Negocios en Puerto Príncipe, y que entendía que, si las condiciones lo exigieran en algún momento, esperaba que su gobierno actuara de igual manera con los cubanos que vivían en Haití. En esa fecha 
Inmigrantes antillanos en Cuba: discursos económicos, raciales e identitarios, 1910-1940

se envió a la legación de Cuba en Haití un cable para que en lo sucesivo se preguntara al Gobierno de Haití en qué puerto deseaba se desembarcase a los repatriados. ${ }^{32}$

La tensión entre los dos Gobiernos se mantuvo a lo largo de los años que duraron las repatriaciones. En el informe remitido el 9 de marzo de 1937 por el encargado de Negocios de Cuba en Haití, José A. Fernández de Castro, sobre las conversaciones mantenidas, el Gobierno haitiano comentaba que el ministro de Asuntos Exteriores le había insinuado que Haití podía reclamar unos 300.000 dólares por perjuicios a sus ciudadanos. ${ }^{33}$

A pesar de esta información, el ministro plenipotenciario de Haití en Cuba volvió a protestar el 31 de marzo de 1937 por las noticias recibidas del cónsul en Santiago el 22 de febrero, quien le contaba que en Guantánamo los soldados habían obligado a los haitianos a ir a un campamento, sin permitirles recoger sus pertenencias, en donde se les confinaba entre $4 \mathrm{y}$ 5 días sin recibir alimentos. Narraba la llegada, el 5 de febrero, de varios haitianos en malas condiciones procedentes del central Oriente después de haber sido saqueadas sus viviendas en presencia de soldados. Declararon que los soldados habían golpeado a un ciego, y habían proporcionado una paliza a "Lequinze Bredy", quien se encontraba en Preston, en el barracón del Chuco, por negarse a pagar el carnet de extranjero que le exigía un soldado antes de ser repatriado. Similares noticias las enviaba el cónsul de Haití en Camagüey sobre 1.300 haitianos procedentes de Jaronú, Minas y Villeta. Allí guardias rurales los habían golpeado hasta vomitar sangre, saqueado sus casas y arrestado, pese a lo cual los haitianos no se atrevieron a denunciar los hechos. El cónsul protestaba porque se les exigiera pagar el carnet de extranjero si iban a ser repatriados, y que, en el caso de no presentar los recibos de haberlo pagado en años anteriores, se les obligase a pagar 4,35 dólares, lo cual era una cantidad onerosa para estos trabajadores. El 3 de abril de 1937, el ministro plenipotenciario, Justin Barau, informaba de la agresión sufrida por Mareus Gustave en la finca La Colonia, en donde trabajaba como colono partidario. El altercado se produjo cuando trataron de quitarle el contrato que acreditaba su condición y Mareus Gustave se resistió. ${ }^{34}$ El 19 de junio de 1937, de nuevo Justin Barau presentó quejas al

32. ANC, Fondo Secretaría de Estado, leg. 213, exp. 2726.

33. ANC, Fondo Secretaría de Estado, leg. 213, exp. 2728.

34. ANC, Fondo Secretaría de Estado, leg. 213, exp. 2727. 
secretario de Estado por el trato dado a los haitianos que era muy diferente al que recibían otros inmigrantes. Se refería a los hechos ocurridos en el central Vertientes, en las colonias Clarita y La Fela, donde fueron despertados en la noche y sometidos a trabajos forzados, en tanto que a otros se les obligó a ir andando hasta Camagüey mientras eran golpeados. Un trato vejatorio recibieron también los trabajadores de la colonia Manantial del central Agramonte a manos de la guardia rural y de soldados. Uno de ellos era un anciano que fue encarcelado. ${ }^{35}$ Similares denuncias las encontramos en la prensa. El Diario de la Marina, a partir del testimonio de Leonce Hyppolite, antiguo gerente del consulado de Haití, publicaba una noticia sobre el trato que se les da a los "pobres negros haitianos en Santiago y Camagüey", que eran obligados a desalojar sus bohíos a punta de machete y culetazos, y a vender sus pertenencias a precios muy bajos, o dejarlas en las viviendas. ${ }^{36}$ En abril de 1937 un artículo publicado en Jamaica recogía el testimonio de Rhoda Ulett tras su regreso de Cuba. Comentaba que, en los últimos tiempos en el central Chaparra, donde había vivido durante 12 años, los antillanos eran tratados como "perros". Tras haber trabajado durante 20 años en Cuba, tuvo que vender sus pertenencias muy baratas para poder pagar el impuesto de residencia, comprar su pasaje y regresar. Denunciaba que miles de antillanos se morían de hambre en Cuba y no podían regresar, por lo que pedía al Gobierno de Jamaica que interviniese. ${ }^{37}$

La situación de descontrol fue aprovechada por algunos que trataron de beneficiarse. Algunos denunciaron que en el consulado de Haití en Santiago de Cuba cobraban el pasaje de repatriación, entre 5 y 10 dólares, a los haitianos que aún no estaban incluidos en la lista de repatriados, diciéndoles que de esa manera podían evitar estar varios días en el campamento. Conocido este y otros hechos similares, el Gobierno de Cuba, que corría con los gastos de las repatriaciones, inició una investigación. ${ }^{38}$

Las condiciones de los barcos que transportaban a los repatriados y los impedimentos que encontraron para desembarcarlos tras llegar a Haití fueron también motivos de conflicto y de negociación entre el Gobierno

35. ANC, Fondo Secretaría de Estado, leg. 213, exp. 2728. 
Inmigrantes antillanos en Cuba: discursos económicos, raciales e identitarios, 1910-1940

haitiano y el cubano. El 7 de febrero, Justin Barau, tras reconocer el barco Rápido, de la Empresa Naviera de Cuba, S. A., en el que serían repatriados haitianos desde Santiago de Cuba a Cayes y desde Nuevitas a distintos puertos haitianos, llamaba la atención acerca del peligro que podrían correr ya que estaba previsto que en él viajaran 500 emigrados, cuando su capacidad era inferior a una carga de 100 personas. Además, se trataba de un barco que no había navegado desde hacía un año. Recordaba que los dueños de ingenios tenían la obligación de repatriarlos en la debida forma y que no era posible que el Gobierno cubano se hiciera cargo de esa obligación y aceptara que la mencionada compañía naviera realizara ese viaje sin los requisitos, la seguridad y la sanidad convenientes. Este problema se resolvió al remplazarse por la embarcación Cuba, que transportó a los primeros repatriados, un total de 409 haitianos. En un telegrama, el 20 de febrero de 1937, Justin Barau agradeció la ayuda del Gobierno por la protección a quienes, recordaba, "habían contribuido, con su labor de la tierra, a la prosperidad de la República de Cuba." ${ }^{39}$ El problema continuó tras arribar en Haití, donde no se aceptó que los pasajeros desembarcasen. Además, durante los primeros meses, el Gobierno haitiano cobró el transporte a tierra en los botes desde el barco, servicio que no podía pagar la mayoría de los haitianos al no tener dinero. Finalmente, el Gobierno haitiano eliminó este cobro el 14 de julio de $1937 .{ }^{40}$ El Gobierno cubano trató de agilizar el desembarco ya que él debía cubrir los gastos que ocasionaban los repatriados a bordo, además del dinero que las autoridades haitianas exigían por el mayor tiempo de permanencia en el puerto. ${ }^{41}$ En un tira y afloja, el ministro de Relaciones Exteriores haitiano, Georges N. Leger, el 20 de febrero de 1937 le comentaba al encargado de Negocios de Cuba en Haití que su Gobierno no había recibido notificación de la repatriación ni de la llegada de este barco, por lo que no permitiría que desembarcasen mientras no se hubiese solucionado el pago de los salarios a los haitianos y el pago de cada pasajero del impuesto de 2 dólares para desembarcar en Haití, del cual solo estaban exentos los emigrantes, que no era el caso de los repatriados a quienes el Gobierno no reconocía como tales. El pago,

39. ANC, Fondo Secretaría de Estado, leg. 213, exp. 2726.

40. ANC, Fondo Secretaría de Estado, leg. 213, exp. 2729.

41. Id. 
unos 1.500 dólares, tendría que hacerlo la compañía naviera. El ministro de Asuntos Exteriores explicaba que al Gobierno haitiano se le creaba una situación muy difícil ante la llegada inesperada de inmigrantes, y que esperaba las propuestas que el Gobierno cubano le hiciera. Mientras se resolvía, el conflicto el barco en el puerto fue puesto en cuarentena. A él subió el encargado de Negocios de Cuba, Fernández de Castro, en Puerto Príncipe, acompañado por un médico para examinar a los inmigrantes y para comprobar el buen estado de los repatriados y las condiciones del barco, y el ministro del Interior de Haití, Frederic Duvigneaud. El capitán del barco le entregó un certificado del cónsul de Haití en Santiago de Cuba, Louis Fils, en el que constaba que se les eximía de pagar 2 dólares a su llegada a Haití. Tras conocer esto, Fernández de Castro telefoneó al ministro de Relaciones Exteriores haitiano, quien tuvo que autorizar el desembarco, solicitó al Gobierno cubano que le indicara el volumen aproximado de repatriados que recibirían. ${ }^{42}$ La prensa local publicó noticias sobre lo ocurrido. Le Matin, en su edición del 22 de febrero de 1937, comentaba la situación de "los desdichados haitianos llegados desde Cuba [...]”. El mismo periódico, el 23 de febrero, dedicó un artículo a la repatriación masiva de 496 haitianos que fueron embarcados de manera urgente sin que pudieran poner en orden sus efectos, y avisaba que se repetirían convoyes sucesivos con repatriaciones masivas desde Cuba. Criticaba las condiciones inhumanas en que se hacían las repatriaciones y planteaba la necesidad de que ambos Gobiernos firmasen un acuerdo para regular las condiciones de repatriación y la conducción a sus domicilioa. ${ }^{43}$ Esta situación volvió a producirse en otros desembarcos, teniendo que mediar el encargado de Negocios de Cuba para explicar de nuevo que el cónsul de Haití en Santiago de Cuba había expedido un certificado eximiendo del pago del impuesto de entrada en Haití. El 23 de febrero de 1937, el vapor Julián Alonso con 700 haitianos fue retenido hasta que se comprobó la documentación. El 3 de marzo los 1.000 haitianos, a bordo del vapor Habana, procedentes de Santiago, también tuvieron que aguardar para desembarcar, al igual que los haitianos a bordo del vapor Rápido, el 10 de marzo. En esa fecha, las autoridades

42. ANC, Fondo Secretaría de la Presidencia, caja 39, exp. 6.

43. Id. 
Inmigrantes antillanos en Cuba: discursos económicos, raciales e identitarios, 1910-1940

cubanas informaban que el número de haitianos a la espera de ser repatriados ascendía a $68.000 .^{44}$

Tras prohibir el desembarco del barco Rápido se trató de llegar a un acuerdo para saber en qué puerto desembarcar, si en Aux-Cayes, donde no dejaron, o en Port de Paix. El encargado de Negocios de Cuba en Haití informaba que este Gobierno decía tener dificultades para hacerse cargo de los repatriados, ya que eran zonas apartadas, e indicaba que, en función de las localidades de los repatriados, los barcos deberían dirigirse al norte, Port de Paix, o al sur, Aux-Cayes. Por su parte, el Gobierno haitiano alegaba que los desembarcos sin previo aviso podían ocasionar disturbios en el país al hacerse en lugares distantes de sus hogares, y que no tenían medios para su traslado, por lo que era preciso que con suficiente antelación se planearan los embarques y desembarques. Para ello, debería distribuirse en los campos de concentración en Cuba a los haitianos en función de los puntos de desembarco. ${ }^{45}$

El 27 de septiembre de 1937 el encargado de Negocios de Cuba en Puerto Príncipe informaba sobre el empréstito que Estados Unidos concedería a Haití para hacer frente a la situación que generaba la repatriación de miles de personas. Este crédito representaba una ventaja para Haití y para Cuba al ser:

La mejor oportunidad que puede presentársenos para deshacernos de una inmigración que nunca fue deseada en nuestro país, pero que el desamor de nuestro pueblo por las labores agrícolas y el salario siempre en baja que se pagaba por el trabajo en el campo, de un lado, y las concesiones que, como secuela obligada de la ausencia de una legislación apropiada, se otorgaron a las empresas azucareras, de otro, hicieron posible y necesaria. ${ }^{46}$

Para las repatriaciones, la Empresa Naviera de Cuba obtuvo un contrato de la Secretaría de Trabajo que contenía algunas ventajas para sus buques como la exención de derechos consulares o de contribución, entre otros.

44. ANC, Fondo Secretaría de Estado, leg. 213, exp. 2726.

45. ANC, Fondo Secretaría de Estado, leg. 213, exp. 2727.

46. ANC, Fondo Secretaría de Estado, leg. 213, exp. 2729. 
Desde Santiago de Cuba y Nuevitas zarparon Rápido, Camagüey, Cuba, Julián Alonso, Columbia. A bordo de estos barcos iban personas de diferentes edades, menores, mujeres y hombres. El número de repatriaciones fue muy diferente en los haitianos y en los jamaicanos. El número de estos fue muy inferior al observado entre los haitianos, cuya permanencia en Cuba en muchas ocasiones era la única posibilidad de supervivencia. Las repatriaciones en 1937 fueron superiores a la cifra dada por algunos autores, quienes estiman que alcanzó 30.000. Según el agente consular honorario de Cuba en Aux-Cayes, Felipe Torres, desde febrero a finales de agosto de 1937, 24.235 haitianos habían llegado a ese puerto. A partir de las listas de embarque localizadas en el Archivo Nacional de Cuba, para esa fecha el número de repatriaciones ascendía a 30.722. ${ }^{47} \mathrm{~A}$ esta cifra hay que sumar las repatriaciones de septiembre a diciembre. Suponiendo que se mantuviese el número de repatriados de los primeros meses, superior a 4.000 , y que la media mensual fuera de 4.389 repatriados, el total podría ser de 48.278.

Durante 1938 y 1939 continuaron las repatriaciones. Los listados que hemos encontrado para estos años son incompletos, por lo que no podemos ofrecer una cifra. Según informe de Benjamin Clermont, cónsul general de la República de Haití en Santiago de Cuba, del 13 diciembre de 1938, en ese año desde allí se habían repatriado 4.798 haitianos a bordo de Columbia, Julián Alonso y San Luis. En la relación de los embarcados figuran hombres y mujeres entre 33 y 45 años, dedicados a trabajar en el campo o con oficio de modistas, muy pocos entre 50 y 60 años, así como menores, ${ }^{48}$

Pese a los controles para frenar la entrada ilegal de migrantes, las condiciones económicas de Cuba y las dificultades para ser contratados, a la altura de 1938 tenemos noticias de la entrada de haitianos. Desde la legación de Cuba en Puerto Príncipe, el 7 de octubre, el encargado de Negocios, Ricardo Sarabasa, informó al secretario de Estado, Juan J. Remos, del tráfico de trabajadores que hacía una goleta bajo bandera inglesa que transportaba a los haitianos junto a mercancías como maíz, café, frijoles, etc. Los braceros eran recogidos en distintos puertos del golfo de Gonave hasta reclutar una cantidad suficiente para dirigirse a la Mole de Saint

47. ANC, Fondo Secretaría de Estado, leg. 213, exp. 2730.

48. ANC, Fondo Donativos y Remisiones, leg. 702, núm. 21 y Fondo Secretaría de la Presidencia, caja 39, exp. 1 y 6. 
Inmigrantes antillanos en Cuba: discursos económicos, raciales e identitarios, 1910-1940

Nicolas, lugar desde el que se divisa la costa de Cuba. Desde allí se dirigía a un punto de la costa de Baracoa, en donde en una finca cafetalera dejaba el cargamento humano y de víveres. Según este informe, este era el tercer viaje ya que con anterioridad el mismo individuo había hecho otros dos viajes, transportando entre 30 y 40 personas. ${ }^{49}$ Alertado el Gobierno de Cuba, en noviembre de 1938 ordenó iniciar una investigación, al frente de la cual se puso al agente de policía Luis Torres Catá, quien ratificó la información sobre la entrada ilegal de haitianos y de mercancías por las costas cercanas a Baracoa, indicando que en el tráfico estaban involucrados varios agentes, y que se desconocían los puntos de desembarco y quiénes se encargaban del embarque de haitianos. ${ }^{50}$

En Cuba, algunos haitianos se resistieron a ser devueltos, por lo que idearon una fórmula al menos para retrasar la partida. Se trataba de un documento expedido por el cónsul de Haití en Santiago de Cuba en el cual se hacía constar que el portador tenía alguna propiedad en Cuba, por lo que tenía que permanecer en el país más tiempo hasta liquidarla. Enteradas las autoridades de esta patraña, rápidamente alertaron sobre el conchabeo del cónsul y los haitianos a quienes se ordenaba reclutar y embarcar, aunque portasen dicho documento. ${ }^{51}$

Las continuas salidas de los haitianos generaron opiniones enfrentadas. A finales de noviembre de 1938, algunas corporaciones de caficultores, como la asociación de cosecheros del café en Santiago de Cuba o el comité conjunto de corporaciones económicas de Guantánamo, protestaron por no tener mano de obra para la cosecha. Los miembros de este comité consideraban que era imposible sustituir el trabajo de los haitianos por braceros de Cuba, por lo que de continuar las salidas el sector se arruinaría. Por ello, en octubre solicitaron que se suspendieran los embarques hasta diciembre, cubriendo así al menos los cuarenta y un días que duraba la cosecha de café. En su escrito se comprometían a colaborar con las autoridades para repatriar haitianos una vez que finalizara la cosecha. ${ }^{52}$ En apoyo a ellos, el gobernador de la provincia de Oriente remitió un telegrama a la Secretaría

49. ANC, Fondo Secretaría de Estado, leg. 212, ex. 2704.

50. Id.

51. ANC, Fondo Donativos y Remisiones, leg. 702, núm. 21.

52. Id. 
de Trabajo, solicitando que las devoluciones de haitianos se suspendieran al menos durante 45 días para que pudiera recogerse el café de Guantánamo y de Yateras. La prensa de la zona calificó de "delictuosa" la actitud de los caficultores, calificando a los haitianos una vez más como "trabajadores indeseables" a los que bajo consideraciones "patrióticas" los hacendados les pagaban sueldos miserables. El 31 de octubre de 1938, el periódico El País publicó un artículo titulado "Malestar por la actitud de determinados alcaldes", apoyando la contratación de cubanos. El 1 de noviembre, incluyó otro artículo similar, titulado "Buena perspectiva para los cubanos", en el que daban la noticia de que se procedía a la contratación de trabajadores cubanos y que esperaban que aplicase la Ley Arteaga y se pagara en efectivo, lo cual no era habitual en esos cafetales. De igual modo, el presidente de la Asamblea Municipal de caficultores de Palma Soriano, en una carta dirigida al secretario de Trabajo, Portuondo Domenech, el 13 de noviembre, respaldó la campaña de repatriación de los antillanos por ser una medida justa y patriótica, ya que, decía:

No nos perjudica en nada en cuanto a las labores en la cosecha de café y demás atenciones a nuestras fincas, somos cubanos y queremos que lo poco o lo mucho que podamos darle a ganar a nuestros obreros campesinos, que sean los cubanos quien nos lo gane. Queremos cubanizar a Cuba. Por lo cual desautorizamos al Sr. Juan B. García que figura como presidente del Instituto Cubano de Estabilización del Café, muy en contra de nuestra voluntad, y sin el apoyo de los caficultores de Oriente en sus gestiones hechas... [para parar la repatriación].

En esta misma dirección apuntaba el escrito del Comité Unidad Obrera de Cienfuegos que, a comienzos de noviembre, informaba de las manifestaciones de los obreros cubanos, reclamando que se les contratara. ${ }^{53}$ Las presiones a favor de la entrada de migrantes chocaron con la situación económica general del país, por lo que un informe de este año aconsejó que no se admitieran ni obreros ni agricultores independientemente de su procedencia, con el fin de proteger a los campesinos cubanos empobrecidos por la expansión del latifundio que se había proletarizado,

53. ANC, Fondo Donativos y Remisiones, leg. 702, núm. 21. 
Inmigrantes antillanos en Cuba: discursos económicos, raciales e identitarios, 1910-1940

incapaces de vender sus productos por la falta de un mercado interno y de trabajar en el sector industrial, del cual carecía el país. Por ello, se subrayaba que "la entrada de nuevos proletarios no haría sino abaratar el jornal del nativo o del ya radicado con la consecuente secuela de agravación del problema doméstico, sin dejar solucionado el del inmigrante". ${ }^{54}$ Ante la urgencia de la situación, y para procurar que el campesino cubano fuera contratado en la siguiente zafra azucarera, el 5 de diciembre de 1938, el Gobierno dictó un decreto, que tenía vigor desde el 1 de noviembre, por el cual se trató de agilizar las repatriaciones autorizándose a embarcar migrantes a los buques mercantes y no sólo a los barcos de la Marina de Guerra encargados de los embarques hasta ese momento. La crisis económica de los años treinta, el descenso de las zafras azucareras y el desempleo pusieron fin al ciclo de la migración en Cuba iniciado en el siglo XIX, que alcanzó un flujo extraordinario en las primeras tres décadas del siglo XX. El país cerró las puertas a la entrada de nuevos migrantes. La crisis obligó a que muchos de los estaban en Cuba solicitaran ser repatriados. ${ }^{55}$

\section{Referencias}

Agramonte, A. (1911). Medidas sanitarias aplicadas a los emigrantes. Boletín de Sanidad y Beneficencia de La Habana, t. 4 (1-6), 428-445.

Álvarez Estévez, R. (1988). Azúcar e inmigración, 1900-1940. La Habana: Editorial Ciencias Sociales.

Anderson, B. (1993). Comunidades imaginadas. Reflexiones sobre el origen y la ilusión del nacionalismo. México: Fondo de Cultura Económica.

Araquistáin, L. (1928). La agonía antillana. El imperialismo yanqui en el Mar Caribe (impresiones de un viaje a Puerto Rico, Santo Domingo, Haití y Cuba). Madrid: Compañía Iberoamericana de Publicaciones; Espasa.

54. ANC, Fondo Donativos y Remisiones, leg. 744, exp. 25.

55. En 1946, según el cónsul británico en La Habana, M. E. Vibert, permanecían en el país 19.530 trabajadores procedentes de las Antillas inglesas. La situación económica obligó a muchos a solicitar su repatriación. Desde la provincia de Camagüey lo hicieron 1.140 de Barbados, 420 de las Islas de Sotavento, 360 de las Islas de Barlovento y 180 de otras islas. Desde la provincia de Oriente pidieron regresar 3.870 de Barbados, 2.160 de Nevis, 1.800 de Antigua, 1.950 de St. Kitts, 720 de Monserrat, 2.605 de San Vicente, 275 de Granada, 360 de Dominicana, 450 de Santa Lucía y 180 de otras islas (Giovannetti, 2018, p. 58). 
Carr, Barr (1998). Identity, Class, and Nation: Black Immigrant Workers, Cuban Communism, and the Sugar Insurgency, 1925-1934. The Hispanic American Historical Review, 78(1), 83-116.

Córdova, F. (1906). Clase y procedencia del inmigrante que debe protejer (sic) el Estado. En Quinta Conferencia Nacional de Beneficencia y Corrección de la Isla de Cuba (pp. 385-391). La Habana: Librería y Papelería La Moderna Poesía.

Chávez, E. (1991). El crimen de la niña Cecilia. La brujería en Cuba como fenómeno social (1902-1925). La Habana: Editorial de Ciencias Sociales.

Duany, J. (2010). Las diásporas de las Antillas hispánicas: Una comparación transnacional. Revista del CESLA, 13(1), 265-286.

Fernández, F. M. (1921). Nota editorial, Crónica Médico-Quirúrgica de La Habana, t. 47, La Habana.

Freyre, O. (1906). Cualidades físico-morales del inmigrante. En Quinta Conferencia Nacional de Beneficencia y Corrección de la Isla de Cuba (pp. 393-398). La Habana: Librería y Papelería La Moderna Poesía.

García González, A., y Álvarez, R. (1999). En busca de la raza perfecta. Eugenesia e higiene en Cuba, 1898-1958. Madrid: CSIC.

García González, A., y Álvarez, R. (2007). Las trampas del poder. Sanidad, eugenesia y migración. Cuba y Estados Unidos (1900-1940). Madrid: CSIC.

Guiteras, J. (1913). Estudios demográficos. Aclimatación de la raza blanca en los trópicos. Anales de la Academia de Ciencias Médicas, Físicas y Naturales de La Habana, t. 50, 98-118.

Hall, S. (1996). Introducción. ¿Quién necesita “identidad"? En S. Hall y P. D. Gay (comps.), Cuestiones de identidad cultural. Buenos Aires-Madrid: Amorrortu Editores, 13-39.

Halperín Donghi, T. (1998). En El espejo de la historia. Problemas argentinos y perspectivas hispanoamericanas. Buenos Aires: Editorial Sudamericana.

Ibarra, J. (1992). Cuba: 1898-1921. Partidos políticos y clases sociales. La Habana: Editorial Ciencias Sociales.

Knight, F. W. (1985). Jamaican Migrants and the Cuban Sugar Industry, 1900-1934. En M. M. Fraginals, F. Moya Pons y S. L. Engerman (eds.), Between Slavery and Free Labor. The Spanish Speaking Caribbean in the Nineteenth Century. Baltimore: The Johns Hopkins University Press, 94-114.

Le-Roy, J. (1923). Estudio sobre la población de Cuba. Boletín de Sanidad y Beneficencia de La Habana, t. 28, 543-547.

Le-Roy, J. (1923-1924). Sobre inmigración anti-sanitaria. Anales de la Academia de Ciencias Médicas, Físicas y Naturales de La Habana, t. 60, 441-470. 
Inmigrantes antillanos en Cuba: discursos económicos, raciales e identitarios, 1910-1940

Meza, R. (1906). Nuestra inmigración útil debe ser protegida. En Quinta Conferencia Nacional de Beneficencia y Corrección de la Isla de Cuba (pp. 305-334). La Habana: Librería y Papelería La Moderna Poesía.

Naranjo Orovio, C. (1998). Cuba, 1898: Reflexiones en torno a la continuidad y a los imaginarios nacionales. Cuadernos de Historia Contemporánea (dossier: 1898: España fin de siglo), 20(1), 221-234.

Naranjo Orovio, C. (2001). La historia se forja en el campo: nación y cultura cubana en el siglo XX. Historia Social, (40), 153-174.

Naranjo Orovio, C. (2005). Blanco sobre negro: debates en torno a la identidad en Cuba, 1900-1920. En F. Colom González (ed.), Relatos de nación. La construcción de las identidades nacionales en el mundo hispánico (vol. 2, pp. 849869). Madrid y Frankfurt: Editorial Iberoamericana; Vervuert.

Ortiz, F. (1906a). Consideraciones criminológicas positivistas acerca de la inmigración en Cuba. En Quinta Conferencia Nacional de Beneficencia y Corrección de la Isla de Cuba (pp. 343-355). La Habana: Librería y Papelería La Moderna Poesía.

Ortiz, F. (1906b). La inmigración desde el punto de vista criminológico. Derecho y Sociología, 1(5), 54-64.

Ortiz, F. (1917). Hampa Afro-Cubana. Los negros brujos (Apuntes para un estudio de etnología criminal) (2. ${ }^{a}$ ed.) Madrid: Editorial- América.

Pérez, L. M. (1927). La inmigración jamaiquina desde el punto de vista social, económico y sanitario. La Tribuna Médica, 2(46), 3 y 6.

Pérez de la Riva, J. (1979). Cuba y la inmigración antillana. 1900-1931. Anuario de estudios cubanos (t. 2). La Habana: Editorial de Ciencias Sociales, 5-75.

Roig de Leuchsenring, E. (1925). La colonia superviva: Cuba a veintidós años de República. La Habana: Imprenta el Siglo XX.

Roig de Leuchsenring, E. (1927a). ¿Se está Cuba africanizando? Carteles, 10(48), 18 y 27.

Roig de Leuchsenring, E. (1927b). El problema, gravísimo para Cuba, de las inmigraciones indeseables. Carteles, 10(49), 14 y 27.

Roig de Leuchsenring, E. (1927c). Lo más negro de nuestra actual africanización no es el negro. Carteles, 10(50), 22.

Santos Fernández, J. (1920). El desarrollo de la población de los países hispanoamericanos y muy especialmente de Cuba. Crónica Médico-Quirúrgica de La Habana, t. 46, 140-147.

Segal, D. y Handler, R. (1993). Introduction: Nations, colonies and metropoles. Social Analysis, (33), 3-8.

Wade, P. (2002). Música, raza y nació. Música tropical en Colombia. Bogotá: Vicepresidencia de la República de Colombia. 


\title{
"Yumecas". West Indies workers en el enclave bananero de la United Fruit Company en el Magdalena (Caribe colombiano), 1900-1940 ${ }^{56}$
}

\author{
Jorge Enrique Elías-Caro \\ Universidad del Magdalena
}

\section{Introducción}

En este trabajo se explicará, grosso modo, cómo se realizó el proceso migratorio como fuerza laboral de miles de personas procedentes de las Antillas británicas para trabajar en el enclave bananero del Magdalena (Caribe colombiano) y su economía integrada entre 1900 y 1940. Estas personas llegaron principalmente de Jamaica, Trinidad y Tobago, Barbados, Santa Lucía y Granada, con la finalidad de atarearse en las plantaciones de la United Fruit Company, en especial, para actividades de cosecha, corte y empaque de la fruta; en mantenimiento de fincas; en los muelles de los puertos de Ciénaga y Santa Marta para la exportación; en el ferrocarril y demás medios de transporte; en la construcción de viviendas y oficinas, al igual que otra infraestructura requerida para el desarrollo de la producción de este sector. Asimismo, se mostrará parte del legado sociocultural que estas personas dejaron en el contexto, en las prácticas agrícolas, la religiosidad y en algunas formas de sociabilidad organizacional.

56. Este trabajo es parte del proyecto "Connected Worlds: The Caribbean, Origin of Modern World". This project has received funding from the European Union's Horizon 2020 research and innovation programme under the Marie Sklodowska Curie grant agreement No 823846. Professor Consuelo Naranjo Orovio, Instituto de Historia-CSIC, directs this project. 
"Yumecas". West Indies workers en el enclave bananero

de la United Fruit Company en el Magdalena (Caribe colombiano), 1900-1940

Para situar en contexto algunos aspectos socioculturales y de raza en estos procesos migratorios, entre las piquerías vallenatas ${ }^{57}$ - uno de los géneros tradicionales de este ritmo musical del Caribe colombiano- más aclamadas que se sostuvo en la primera mitad del siglo XX, sobresalió la de los acordeonistas y compositores Emiliano Zuleta Baquero y Lorenzo Miguel Morales, "Moralito". Los duelos por el toque de acordeones y los versos cantados entre estos cantautores eran un desafío constante, donde el mensaje despectivo enviado hacia el oponente era lo más significativo (ofensa, burla, descrédito, etc.) El desafío musical más conocido entre estos personajes se remonta hacia 1938, cuando el primero de ellos compuso una de las canciones vallenatas más conocidas en el mundo (cantada y traducida en varios idiomas), titulada La gota fría (Aponte, 2011, pp. 83-87). En ella, Zuleta Baquero, para despreciar y ofender a su contendor y expresarle que es una persona de tez negra, sin mayor formación, con falta de cultura y nacido en una zona rural, a través de versos decía:

¿Qué criterio, qué criterio va a tener un negro yumeca ${ }^{58}$ como Lorenzo Morales...

¡ayyy! Qué criterio va a tener,

si nació en Los Cardonales? ${ }^{39}$

A lo largo de la composición musical, lo que Zuleta perseguía era ofender y humillar a su rival. Y para hacerlo en forma peyorativa, le define como un negro yumeca; es decir, con esta canción lo "ofende" por poseer unas condiciones desdeñosas. Primero, debido a su alta melanina en la piel, como se ilustra en la fotografía 1, y segundo, en alusión a lo yumeca.

57. Es una contienda musical amistosa, de colegas y "parranda", pero que en el juego de las composiciones y los versos se busca ofender y desacreditar al rival.

58. Las cursivas las agregamos para resaltar las palabras.

59. En la versión original de La gota fría (1938) aparecían las palabras negro yumeca, pero el cantautor Carlos Vives en su adaptación de fines del siglo XX las cambia sin ninguna justificación por indio yumeca. El término negro utilizado en la canción inicial es despreciativo. Además, enfatiza que es de los Cardonales, o sea, oriundo de los Cardonales de Guacoche, zona apartada de Valledupar, para enfatizar el origen humilde y campesino del otro. 
Figura 1. Lorenzo Miguel Morales, "Moralito"

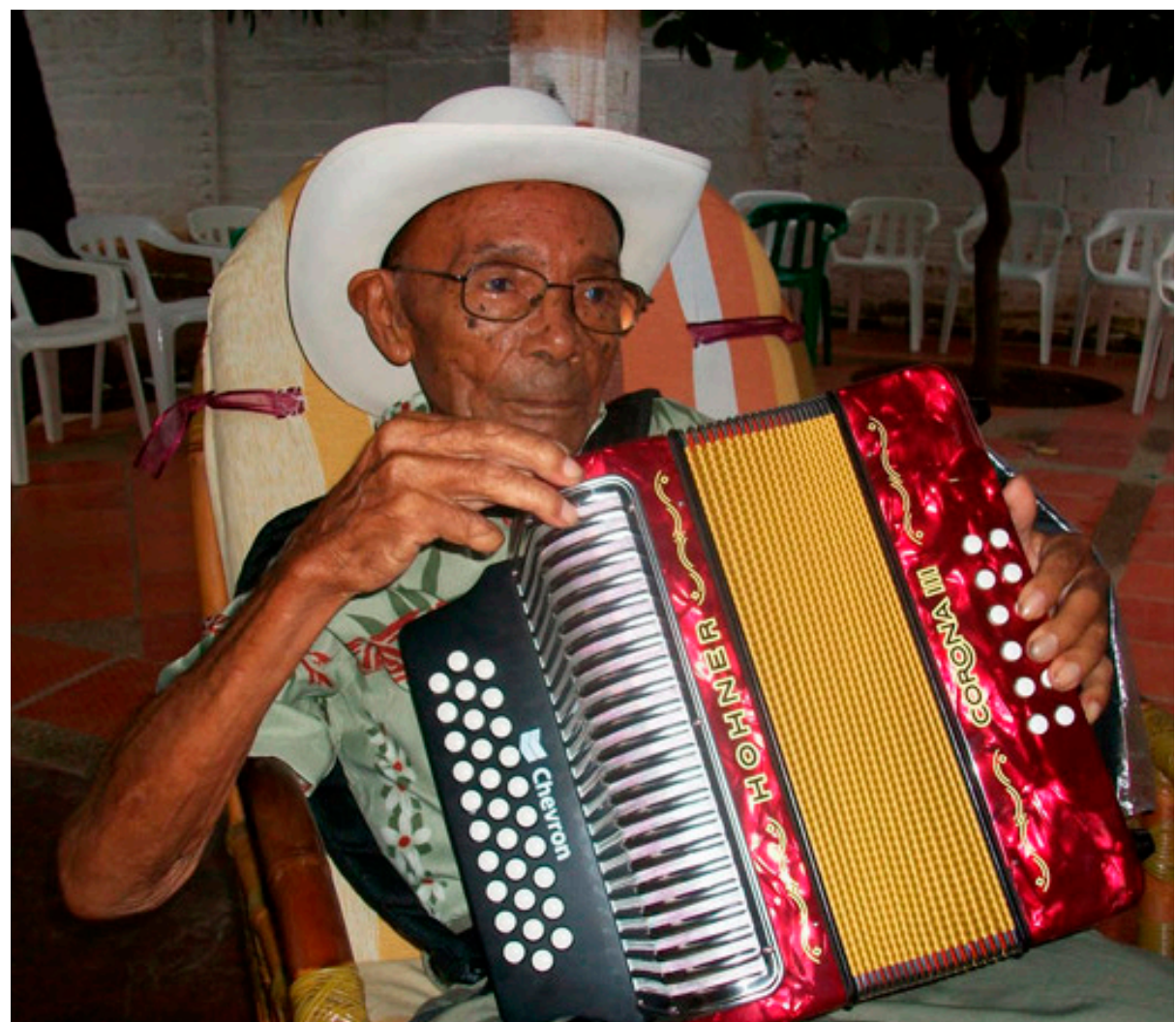

Fuente: La República EC. Sección Gente, agosto 26 de 2011.

Por "yumeca", en la historia social e historiografía regional del Caribe colombiano, se conoce a las personas antillanas de piel negra procedentes de las islas del Caribe anglófono que llegaron a trabajar en las plantaciones bananeras y el complejo económico de la United Fruit Company (UFCo) en el departamento del Magdalena. Esta migración duró más de cuatro décadas, en especial, a fines de la centuria decimonónica, previamente por la construcción del canal de Panamá y posteriormente con la llegada de la multinacional norteamericana a comienzos del siglo XX, más precisamente en 1901 (Elías-Caro y Vidal, 2013, pp. 1-26).

No hay una fuente concreta que lo compruebe, pero la oralidad magdalenense dice que la palabra "yumeca" es una mala castellanización del 
"Yumecas". West Indies workers en el enclave bananero de la United Fruit Company en el Magdalena (Caribe colombiano), 1900-1940

del término inglés jamaican, que es el gentilicio de las personas procedentes de la isla de Jamaica, que fonéticamente hablando acabó por ser de forma sonora yamaican, pasando a escribirse y pronunciarse yumeca. Al final, se les denominó "yumecas" a todos los que llegaban de las islas que el Imperio británico que tenía en el Caribe para trabajar en la Zona Bananera de Magdalena, el ferrocarril, el puerto de Santa Marta y el municipio Ciénaga y sus áreas de influencia, sin importar que fueran de Jamaica, Barbados, Trinidad, Tobago, Granada, Santa Lucía, entre otras, así como también de las francesas Martinica y Guadalupe y de las de Países Bajos como Aruba, Curazao y Bonaire. La procedencia de este trabajador, recordada con el término "yumeca", se reforzaba con la inclusión de otro adjetivo para referirse a él, "negro yumeca". Dicha definición, como veremos, encerraba los conflictos sociales y laborales generados con su presencia (Rey Sinning, 2006, p. 3).

A estas mismas personas, por su color de tez y proceder de las Antillas británicas, también se les denominó "blacamanes" desde un sentido plural de la sociedad o "blacamán" para referirse a una sola persona, ya que fue la traducción del término al castellanizar las palabras compuestas del inglés black man. Sobre "blacamanes" son muchos los conceptos despectivos que existen. El término es resaltado por el nobel de literatura colombiano Gabriel García Márquez en uno de sus cuentos, titulado Blacamán el Bueno, vendedor de milagros, del que se han desprendido varios trabajos desde la crítica literaria y los estudios culturales (García Márquez, 2013). Desde la historiografía regional, Aramis Bermúdez (2012) es quien más ha trabajado el concepto de "blacamanes" y explica quiénes fueron estos hombres negros (black man) en el mundo de Macondo sin realismo mágico en su libro Migrantes y blacamanes en la Zona Bananera del Magdalena. Ante esta situación de desprecio y ofensa que era ser "negro yumeca" o "blacamán” en el Magdalena entre 1900 y 1950, Moralito hace una canción de respuesta a Zuleta Baquero, en la que, a través de un paseo vallenato titulado Rumores ${ }^{60}$, intenta contrarrestar la burla hecha en La gota fría y responderle con otra interpretación poética despectiva hacia este, aunque no fue tan afamada ni tuvo la resonancia nacional e internacional de la primera ("Piquería", 1999):

60. Esta canción también se conoció como La carta. 
...Yo conozco el pique que me tiene Emiliano, me anda criticando que yo soy negro yumeca, ${ }^{61}$ pero él no se fija que es blanco descolorido ${ }^{62}$ ¿Qué le pasa a Zuleta que no puede con la maleta?...

Como se puede evidenciar en la respuesta de Lorenzo Morales, se afirma el descrédito de Zuleta hacia Moralito de "negro yumeca", en contraposición con el objeto de vilipendiar también a su rival de pique, lo ofende con decirle que es un "blanco descolorido". En este verso de solo cuatro renglones se denota un duelo, no solo por la supremacía musical de las composiciones, sino también de clases sociales y reyerta racial entre negros y blancos.

En este trabajo se mostrarán las relaciones existentes entre los trabajadores que llegaron a laborar en el tejido productivo formado por el sector bananero y la United Fruit Company - provenientes de Jamaica y demás islas del mundo anglófono del Caribe- con las dinámicas propias del departamento del Magdalena, en especial desde factores sociales, culturales y económicos. Además, se explicará cómo fue este proceso migratorio mediante el uso de estadísticas, las cuales permitieron obtener cifras y hacer tablas y gráficas de la información hallada en diferentes archivos históricos en Colombia y el extranjero. Por la escasa historiografía que existe en el estado del arte conceptual, teórico, metodológico y de contextos sobre el tema, podemos afirmar que este trabajo es pionero, pues no hay otro de características similares, lo que daría pie para ser consultado como referencia en ulteriores investigaciones, ya que resultará de suma importancia para la historia de las migraciones en el Caribe colombiano en la primera mitad del siglo XX, la economía bananera grancaribeña y la sociedad del Magdalena alrededor del enclave de la multinacional.

\section{Lo que dice la historia y no hace visible la historiografía}

La historiadora estadounidense Catherine Legrand comenta que es casi nulo lo que se ha escrito sobre los yumecas en Colombia. La escasa historiografía social y económica existente sobre el tema se relaciona con la fuerza

61. Las cursivas las agregamos para resaltar las palabras.

62. Las cursivas las agregamos para resaltar las palabras. 
"Yumecas". West Indies workers en el enclave bananero

de la United Fruit Company en el Magdalena (Caribe colombiano), 1900-1940

del trabajo en la construcción del canal de Panamá; sin embargo, una cosa excepcional para resaltar de la UFCo en Colombia es que no "importó" la mayoría de su mano obra de las islas británicas del Caribe (a diferencia de la UFCo en Costa Rica, Honduras, etcétera); aspecto que Franklin Knigth también comenta bajo la misma premisa. ${ }^{63}$ Parece que había muchos "colombianos" para hacer el trabajo de las plantaciones bananeras, y eran los que provenían de las islas nacionales de San Andrés, Providencia y Santa Catalina, así como de otras partes del Caribe colombiano que, en migraciones internas desde pueblos de negros del departamento de Bolívar, sobre todo en la Colonia y primera mitad del siglo XIX, habían sido palenques o rochelas. Además, había leyes (a nivel nacional y departamental) contra esta inmigración (ver la figura 2).

Figura 2. Mapa que denota la Zona Bananera del Magdalena en la región Caribe colombiana.

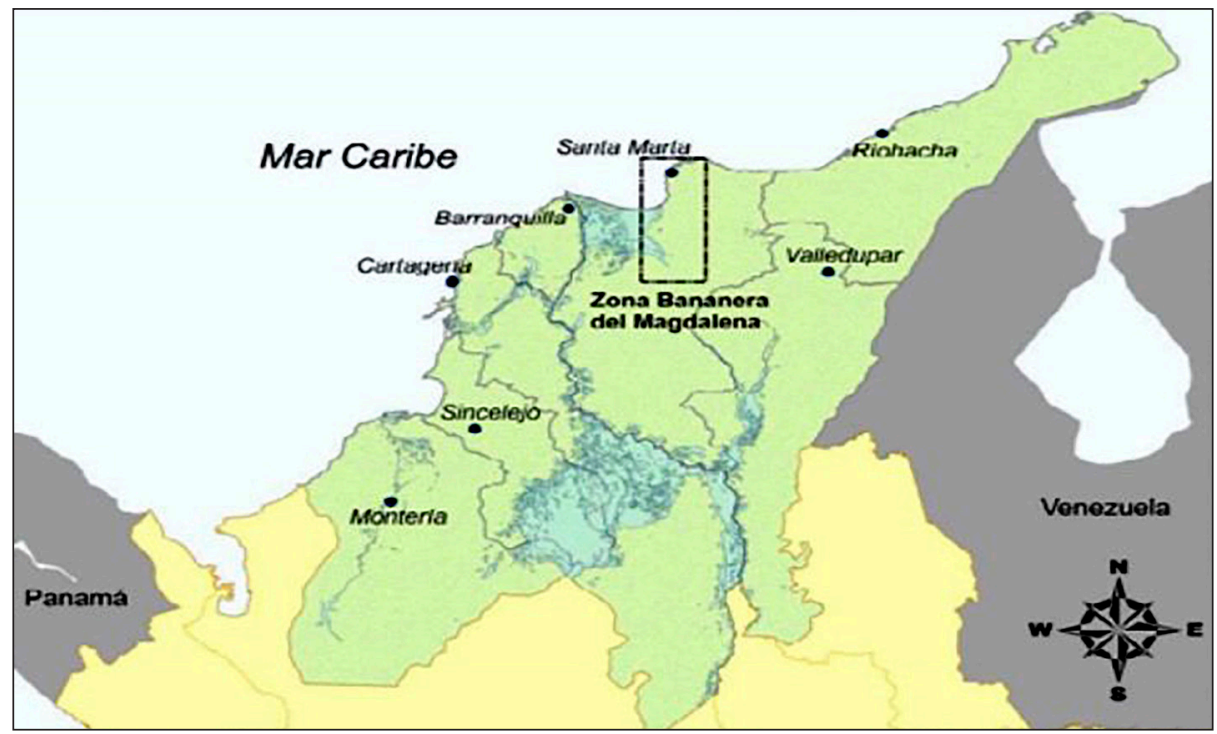

Fuente: Meisel (2010, p. 7).

63. En mensaje enviado por este el 21 de octubre de 2015, escribe: “Tengo muchas preguntas del porqué hay pocas publicaciones que tratan sobre las migraciones, como fuerza laboral, entre las Antillas británicas y Colombia, aunque sí existen muchos sobre el tema de antillanos en Panamá y los países centroamericanos". 
Jorge Enrique Elías-Caro

Al respecto, Henderson (2001), basado en un artículo publicado en el periódico colombiano El Tiempo el 3 de octubre de 1922, escribe:

Rafael Reyes's remark of 1919, that while Colombia should encourage immigration - even Japanese immigration - it should prohibit entry to Chinese and Hindus, "races made degenerate through servility." Three years later, in 1922, members of the national Congress passed a law prohibiting the immigration of Chinese, Hinduas and Turks (Otomanos), but encouraging European immigration. That same year a writer for El Tiempo protested Tropical Oil's use of Jamaican guest workers in its Colombian fields, a charge the company "enthusiastically denied". Still, the editorialist concluded, "we hope the government has already taken the means necessary to put an end to an immigration that is absolutely undesirable in every sense, not only because it causes competition for Colombian workers, but because of the grave damage it does to our race" (p. 86).

Aparte de lo anterior, en Colombia se generalizó cierto rechazo a todo lo que no fuera nacional y en especial a lo procedente de Inglaterra y sus colonias, motivado sobre todo por la guerra que sostuvo la nación con su vecino país, Perú, entre 1932 y 1933, por el dominio territorial fronterizo del trapecio amazónico (Valencia et al., 2001; Ospina, 2006). En esos hechos bélicos, varios países como Estados Unidos, Alemania e incluso Brasil, que estaba cerca de la condición geográfica por la que se originó esta pugna internacional, se inclinaron por Colombia. La excepción fue Gran Brataña, que tomó partido a favor de la causa peruana, tal como afirmó Tomás Uribe (2013):

Durante el conflicto y antes del mismo, Alemania y EE. UU. favorecen a Colombia. Brasil se declara formalmente neutral, pero también se inclina hacia nuestro país. En cambio, el Reino Unido mantiene una actitud de simpatía hacia la causa peruana. Las gestiones del general Vásquez Cobo para adquirir naves de guerra prosperan en Francia y Alemania, mas no en el Reino Unido, España e Italia, por cuenta de las eficaces gestiones diplomáticas peruanas. Sin embargo, logra contratar la fabricación de dos destructores por una firma británica, pero en Portugal (p. 43). 
"Yumecas". West Indies workers en el enclave bananero

de la United Fruit Company en el Magdalena (Caribe colombiano), 1900-1940

En Colombia, después de 1933, por tales circunstancias, se generó cierta animadversión contra todo lo que se fuese británico, y de ahí que en el sentido patriótico y de defensa de la soberanía por el conflicto con Perú (Cavelier, 1997) y, justamente, la postura que asumió el Imperio británico de apoyar al enemigo (Donadio, 2002; Garay, 2009), se aplicó la ley popular que versa: "Los amigos de mis amigos serán mis amigos y los amigos de mis enemigos serán mis enemigos". ${ }^{4}$

Así las cosas, las migraciones de antillanos de procedencia de espacios británicos en Colombia para la primera mitad del siglo XX fue un escenario de grandes altibajos. Sus flujos guardan relación no solo con las relaciones internacionales, sino con el contexto económico, político, cultural y social, que para el caso específico del país, en la historiografía ha sido escasamente visibilizada, poco tratada y no ha despertado el interés que merece. Solo se conoce el compendio publicado por Annette Insanally en 2004 en el que analiza el impacto socioeconómico y cultural de la migración laboral de gente West Indies a Colombia. En contraste con otros espacios geográficos del Caribe, en donde, al analizar la historia comparada de estos, existe una producción significativa.

\section{La migración antillana anglófona a la Zona Bananera del Magdalena y el enclave de la UFCo}

Los datos mostrados en la gráfica 1 dan cuenta de la procedencia de los trabajadores que llegaron a trabajar en las plantaciones de la UFCo para las primeras cuatro décadas del siglo XX. Como fuerza de trabajo, la isla de Jamaica, con 58\%, fue el espacio afroantillano británico que más aportó migrantes al Caribe colombiano, seguido de Granada con 19\% y luego Trinidad y Tobago, Santa Lucía y Barbados con un porcentaje significativo, aunque ninguno superó $10 \%$. En la siguiente gráfica se ilustra la procedencia de yumecas al negocio bananero y sectores conexos en el departamento del Magdalena entre 1900 y 1940. Para el caso de los que procedían de Granada, la mayor parte venían de una isla dependiente de esta, llamada Carriacou.

64. La guerra colombo-peruana estuvo ligada a la invasión de aproximadamente 17.000 militares peruanos a la ciudad de Leticia, localidad de Colombia situada en la frontera entre ambas naciones y el arco brasileño, suceso que originó el conflicto (Valencia, et al., 2001; Ospina-Peña, 2002). 
Jorge Enrique Elías-Caro

Gráfica 1. Procedencia de los trabajadores de la UFCo de las Antillas británicas, 1900-1940

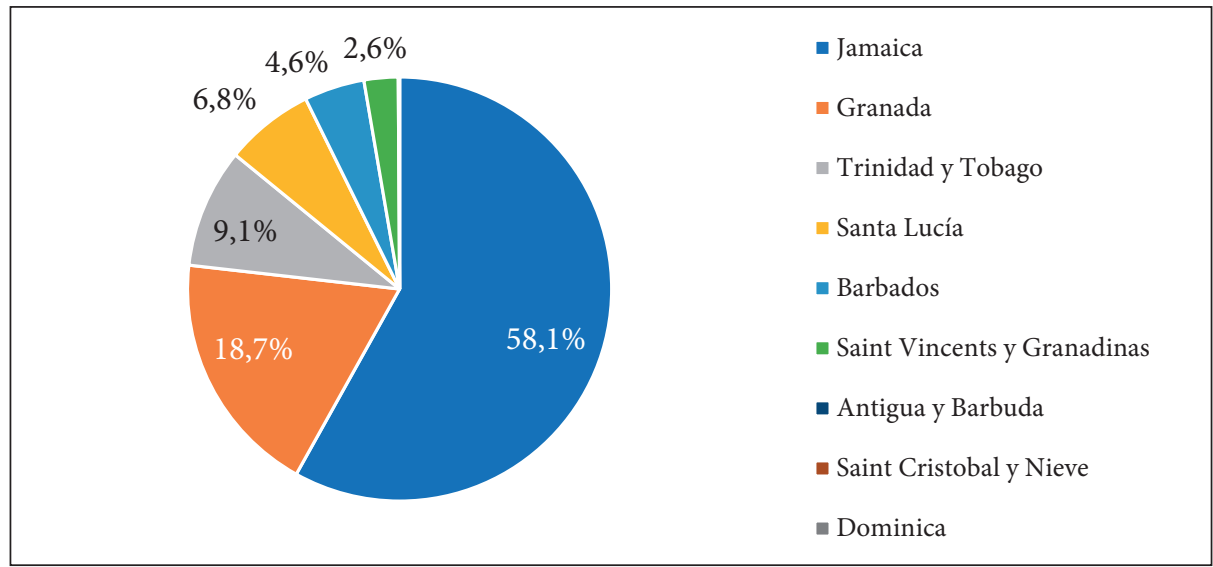

Fuente: Cálculos propios con base en unificación de fuentes. Archivo General de la Nación (AGN). Ministerio de Relaciones Exteriores. Fondo consulados, 1890-1940; Archivo Histórico del Magdalena Grande (AHMG), Periódico El Estado de 1921-1940, Santa Marta; AHMG, Gaceta Departamental del Magdalena, 1915-1940, Santa Marta; Biblioteca de la Universidad Cooperativa de Colombia (BUCC), Diario Oficial, 19001940, Bogotá; (BUCC) El Registro del Magdalena, 1895-1915, Santa Marta; AHMG; Fondo Cajas Departamentales. Legajos y carpetas de documentación varia, 1890-1940, Santa Marta.

En cuanto a cantidad de migrantes ingresados a la Zona Bananera del Magdalena y el enclave de la multinacional, no existen datos exactos por la dispersión de la información que hay sobre el registro en el momento de hacer la entrada de personas por el puerto de Santa Marta. A esto se suma la falta de archivos históricos y la continuidad de la serie en las estadísticas, que permitiera hacer una valoración de manera aproximada sobre este proceso migratorio durante casi media centuria. Metodológicamente no fue posible hacer este trabajo por anualidad, lo que obligó a hacerlo por quinquenios. Entre 1895 y 1945, o sea, en medio siglo de historia en la producción y comercialización de la fruta en la Zona Bananera del Magdalena, alrededor de 35.000 antillanos entraron de las islas del Caribe a trabajar para la UFCo, siendo 1928 el año en que más se introdujo mano de obra importada, con casi 7.500 yumecas, seguido de 1937 con 6.200 y 1927 y 1938 con 3.500, respectivamente (ver la gráfica 2). 
"Yumecas". West Indies workers en el enclave bananero

de la United Fruit Company en el Magdalena (Caribe colombiano), 1900-1940

Gráfica 2. Ingreso de antillanos anglófonos en el Magdalena, 1895-1940

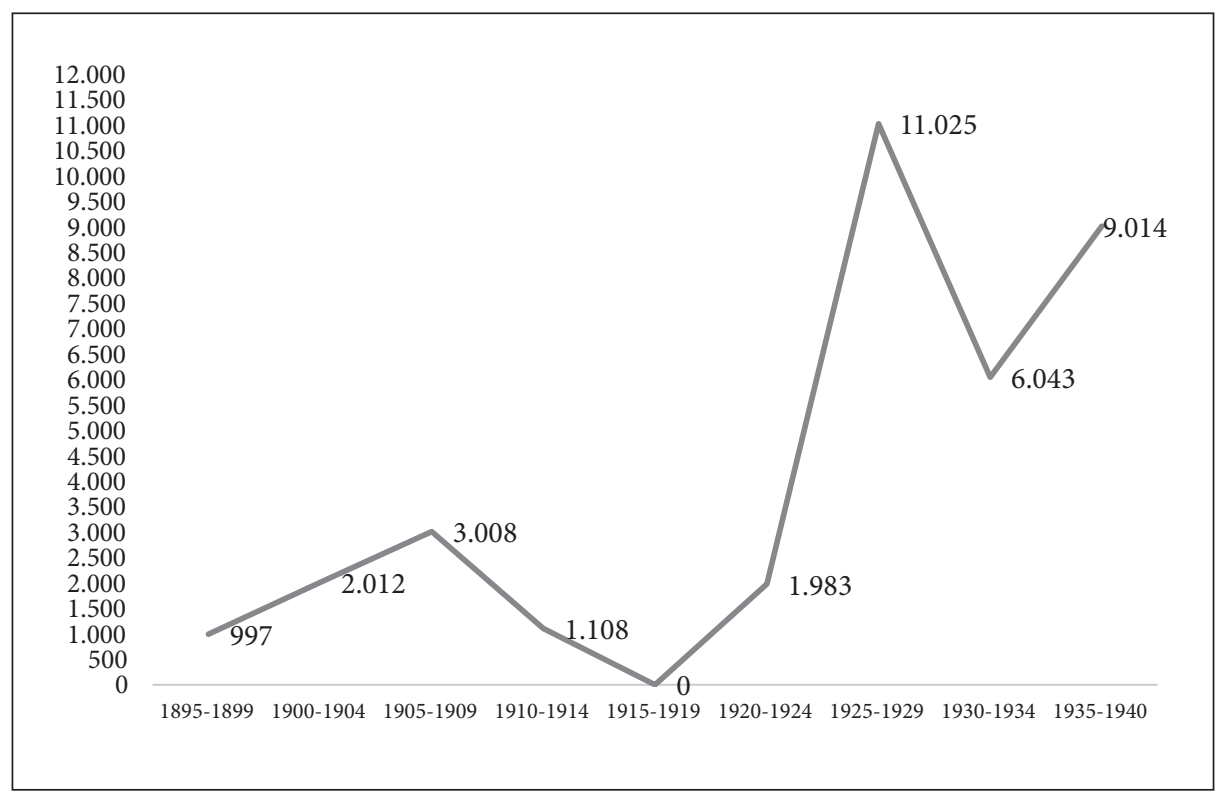

Fuente: Cálculos propios con base en unificación de fuentes. Archivo General de la Nación (AGN). Ministerio de Relaciones Exteriores. Fondo consulados, 1890-1940; Archivo Histórico del Magdalena Grande (AHMG), Periódico El Estado de 1921-1940, Santa Marta; AHMG, Gaceta Departamental del Magdalena, 1915-1940, Santa Marta; Biblioteca de la Universidad Cooperativa de Colombia (BUCC), Diario Oficial, 19001940, Bogotá; (BUCC) El Registro del Magdalena, 1895-1915, Santa Marta; AHMG; Fondo Cajas Departamentales. Legajos y carpetas de documentación varia, 1890-1940, Santa Marta.

De ahí que el quinquenio 1925-1929 fuera el de mayor reporte, con un poco más de 11.000 angloparlantes ingresados. Posteriormente, el de 1936-1940, con casi 9.000, seguidos en su orden por los de 1931-1935 con los aproximadamente 6.000 ingresados, 1906-1910 con un poco más de 3.000 y los demás períodos que estaban por debajo de 2.000 en los cinco años cuantificados, como se puede evidenciar en las gráficas 2 y 3 . No obstante, es oportuno resaltar que si se analizan las cifras de registro de 1927 y 1928, solo en esas dos anualidades sumadas se hallaron aproximadamente 11.000 personas que ingresaron. A partir de estos datos inéditos, podemos pensar que su presencia pudo haber sido también uno de los detonantes de la huelga de las bananeras que ocasionó posteriormente 
la matanza de los obreros por parte de las fuerzas del Estado colombiano la noche del 6 de diciembre de 1928. Sabemos que el asunto de la mano de obra importada por parte de la empresa extranjera en detrimento de la nacional fue uno de los puntos por debatir en las negociaciones colectivas que no se lograron convenir en los pactos laborales entre los movimientos obreros locales, los sindicatos, la dirigencia de la UFCo y las autoridades gubernamentales tanto nacionales como regionales (Elías-Caro y Vidal Ortega, 2012; 2013).

Gráfica 3. Ingreso de antillanos anglófonos en el Magdalena, 1895-1940

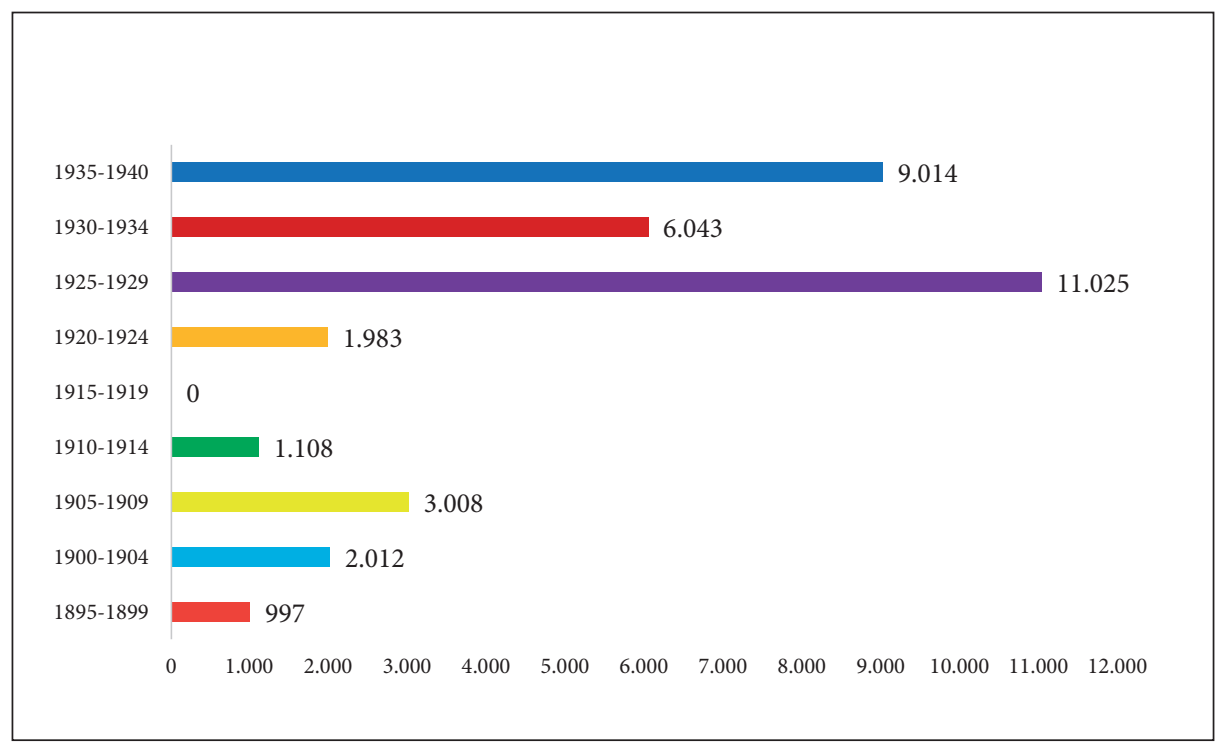

Fuente: Cálculos propios con base en unificación de fuentes. Archivo General de la Nación (AGN). Ministerio de Relaciones Exteriores. Fondo consulados, 1890-1940; Archivo Histórico del Magdalena Grande (AHMG), Periódico El Estado de 1921-1940, Santa Marta; AHMG, Gaceta Departamental del Magdalena, 1915-1940, Santa Marta; Biblioteca de la Universidad Cooperativa de Colombia (BUCC), Diario Oficial, 19001940, Bogotá; (BUCC) El Registro del Magdalena, 1895-1915, Santa Marta; AHMG; Fondo Cajas Departamentales. Legajos y carpetas de documentación varia, 1890-1940, Santa Marta.

Las gráficas 2 y 3 muestran un incremento paulatino en la década de 1920 a 1929, que después de 1930 registra un leve descenso, como consecuencia de la crisis económica mundial. Entre 1927 y 1929, hubo grandes 
"Yumecas". West Indies workers en el enclave bananero

de la United Fruit Company en el Magdalena (Caribe colombiano), 1900-1940

cantidades de inmigrantes afro-angloparlantes. Este trienio superó 11.000 personas ingresadas. Caso contrario sucedió con la década de 1910 a 1920, ya que ese lapso fue de escasa trashumancia laboral. En este tiempo hubo años en los que no inmigraron yumecas. Primeramente, por los diversos procesos que surtieron efecto en la economía bananera a consecuencia de la Primera Guerra Mundial y, en segundo lugar, por las restricciones que para esa época el Gobierno nacional de Colombia y el local del Magdalena estaban implementando para evitar este ingreso descontrolado de personal extranjero. Hubo leyes prohibitivas que impedían su ingreso.

Un caso que muestra estos aspectos legales y de restricciones, pero además de rechazo a estas migraciones, se puede observar en lo publicado en el periódico La Voz de Santa Marta en su número 26, fechado octubre 23 de 1910, que dice lo siguiente:

Consulado de Colombia. - Kingston, 6 de octubre de 1910. 20 East Street.

Señor jefe del Resguardo. Santa Marta.

Señor: Debo poner en conocimiento de Usted que la United Fruit Company empieza a establecer una corriente de inmigración entre esta isla y ese puerto. Lleva trabajadores para emplearlos en sus plantaciones de bananos en esa región. He informado al Superintendente de dicha compañía aquí que los emigrantes a Santa Marta deben ir provistos del respectivo Pasaporte de este Consulado, pero este señor me ha contestado, por teléfono, que no cree que la inmigración deba llenar en este Consulado requisito alguno, desde el momento mismo que en Santa Marta no existe ni vigilancia ni sanidad.

He escrito al Señor ministro sobre el particular, y espero sus instrucciones por cable. El asunto es de vital importancia: $1^{\circ}$ En esta ciudad existe una enfermedad muy contagiosa conocida bajo el nombre de tracoma, por lo cual, se hace necesario que todo inmigrante de éste a ese puerto, vaya provisto de un certificado médico debidamente legalizado en este Consulado, sin el cual no se le permitirá su desembarque; $2^{\circ}$ Como ésta inmigración es la que menos le conviene fomentar a nuestro país, por componerla - gentes de pésimas costumbres que apenas van a esa región a abaratar el jornal con perjuicio del trabajador colombiano-, debe exigírsele a 
Jorge Enrique Elías-Caro

cada inmigrante la presentación del Pasaporte de este Consulado. No se extenderá dicho pasaporte a individuos que hayan sufrido condena, por lo cual, cada inmigrante tendrá que presentar en este Consulado un buen testimonio de buena conducta, de persona conocida en esta isla.

Es verdad que nuestro país necesita de inmigración, pero de gente sana, blanca, de buenos hábitos, ${ }^{65}$ que se establezcan en el país con sus familiares y que desarrollando nuestras riquezas naturales y estableciendo industrias útiles, formen una corriente de circulación monetaria.

Es bueno que Usted informe al Superintendente de la United Fruit Company en ese puerto de los requisitos que debe llenar en este Consulado la inmigración.

De Usted muy atento y seguro servidor, F. López Pomareda ( $L a \mathrm{Voz}$ de Santa Marta,1910).

La respuesta por parte del funcionario no se hizo esperar y reconoce el error por parte de la administración local de la plaza samaria debido a una mala interpretación de la norma. Inmediatamente se corrigió el error cometido, y se aplicó con todo el rigor ese mandato, con el fin de evitar la entrada de personas "indeseables", de malas costumbres y con enfermedades en la piel y la vista, condiciones que se les atribuía por su condición de ser negros. Para ello hizo una comunicación oficial del resguardo de Santa Marta, con número seriado 247, calendada octubre de 1910, en la cual se expresa abiertamente:

República de Colombia. Resguardo Nacional. No. 247. Santa Marta, octubre de 1910.

Señor Cónsul de Colombia. Kingston.

Señor: Por Decreto Legislativo No. 38 de 1908, el Gobierno colombiano dispuso no permitir la entrada en este país de los individuos que no vengan provistos del Pasaporte Consular a que hace Usted referencia

65. El uso de cursivas en las palabras no corresponde al texto original, se utilizan aquí con el fin de resaltar el contenido de las mismas. 
"Yumecas". West Indies workers en el enclave bananero de la United Fruit Company en el Magdalena (Caribe colombiano), 1900-1940

en su atenta carta oficial del día 6 del mes que cursa, y el Ministro de Gobierno, en comunicación del 25 de enero del presente año, me ordenó, por conducto de la Gobernación del Departamento, abstenerme de exigir el mencionado Pasaporte a los colombianos que regresen al país; a mi vez aquella formalidad quedó en pie para los extranjeros y el precitado Decreto, salvo la restitución anotada, en riguroso vigor.

Una mala interpretación en que incurrimos, no sólo yo, más también las autoridades de los demás puertos, nos hizo creer que la orden del Ministerio de Gobierno no solamente se refería a los colombianos, sino que implícitamente derogaba en su totalidad el Decreto sobre "Policía de Puertos"; de aquí el haberse omitido el requisito que por aquél se estableció, y que juzgo yo tan de vital importancia y tan oportuno a prevenir los graves males a que Usted se refiere, que mientras el Gobierno resuelve lo conveniente, acogiéndome a la vigencia de la disposición legislativa ya indicada, lo implantaré con toda escrupulosidad. Al efecto, me dirijo hoy al señor Gerente de la "United Fruit Company", para que se sirvan dar las órdenes que fueren de su resorte.

Soy muy atento: Seguro servidor de Usted, Roberto Ospina Pradilla

La mala interpretación se dio básicamente porque para ese entonces estaba también entrando gente que procedía de las islas colombianas de San Andrés, Providencia y Santa Catalina con características similares: con piel oscura y que hablaban inglés perfectamente, pero que por provenir de allí no les exigían el pasaporte. ${ }^{66}$ Por otra parte, en esos viajes, al entrar las embarcaciones al puerto de Santa Marta, eran muchas las personas que venían de Jamaica, pero que por su cercanía geográfica y como parte de las rutas de navegación, hacían escala en el archipiélago, y después, al llegar a la ciudad por los circuitos comerciales que existían entre las islas y el continente, se hacían pasar como nacionales colombianos (sanandresanos o providencianos), de ahí que la Policía portuaria no les exigiera este soporte legal de admisión al territorio.

66. Hasta 1912 se crea la Intendencia del Archipiélago de San Andrés, Providencia y Santa Catalina. Antes de eso, para la fecha del caso, octubre de 1910, estos espacios insulares administrativamente desde 1886 eran parte del departamento de Bolívar y se adhirieron por la puesta en marcha de la nueva reforma que se instauró en Colombia fruto de la nueva Constitución Política. 
Sin embargo, el funcionario del resguardo como autoridad oficial en materia de inmigración, al reconocer el error manifestó que tomaría las medidas necesarias inmediatamente para contrarrestar lo sucedido, debido a que con la inmigración de yumecas "son más los males que aportan que beneficios"; incluso, aludía a aspectos sanitarios al comentar que estos migrantes podían ser portadores de enfermedades contagiosas, por lo que su entrada debía evitarse por ser gente de "raza inconveniente y pésimas costumbres". Esto se puede ver en una nota marginal que hace al final de la carta dirigida al consulado colombiano en Kingston, donde en forma despectiva expresa lo siguiente:

Para café tinto y con leche ya aquí tenemos en cantidad suficiente y no necesitamos más. La contagiosísima enfermedad de gios conocida con el nombre de tracoma ${ }^{67}$ es horripilante flagelo del cual debemos librarnos por todos los medios posibles, hasta el de la fuerza, ya que el Superintendente de la United Fruit Company, en Kingston, ha hecho la insólita declaración de que aquí en Santa Marta no existe ni vigilancia ni sanidad que impida la inmigración de negros, raza inconveniente y de pésimas costumbres, y quien sabe que más.

Es tiempo de que el Gobierno haga cumplir las leyes sobre inmigración y adoptar medidas tendientes a prevenir grandes males.

Las estrategias y comunicaciones para hacer notar el malestar generalizado de los habitantes de la región por esta inmigración fueron constantes, inclusive, más allá de lo publicado en la prensa local. Es más, proviene desde los inicios del siglo. Ya para 1907, prefería, que llegaran personas con tez blanca y además que hablaran español. La cuestión de la raza, el idioma y el color de piel estuvo en boga en estas migraciones laborales, no solo para lo referente a los cultivos de banano en la Zona, sino para otras plantaciones, que sería el caso del café en las estribaciones de la Sierra Nevada. Estas diferencias en las categorías raciales se pueden ver con los procedentes de Puerto Rico, personas que llegaron a trabajar en las haciendas cafeteras y hacia quienes la gente local no tuvo animadversión. Por el contrario, pedían que se promoviera su in-

67. Es una enfermedad que se presenta por un trastorno oftálmico. 
"Yumecas". West Indies workers en el enclave bananero

de la United Fruit Company en el Magdalena (Caribe colombiano), 1900-1940

migración; ejemplo de ello fue la contratación de puertorriqueños en la finca Cincinatti, propiedad de la familia estadounidense Flye, como consta en la noticia publicada en el periódico de Santa Marta Ecos del Magdalena, núm. 17, de junio 21 de 1907, en el que se expresa la argumentada nota, así:

Inmigración. - En el vapor $<$ Sardinia $>$, hace pocos días, procedentes de Puerto Rico, llegaron diez familias (unas cien personas) que el Señor Orlando L. Flye, ciudadano americano residente en Santa Marta, contrató en aquella isla para los trabajos de recolección de café en "Cincinatti", Sierra Nevada. Personas de color moreno y cabellos lacios, tipos muy semejantes a los de nuestra raza; hablan español y son gentes sencillas, cultivadoras $y$ de muy buenas costumbres. ${ }^{68}$

Caso que, como se ha explicado, no ocurría con los jamaicanos, trinitarios o barbadenses. No cabe duda de que la importación de esta mano de obra se debía a la experiencia laboral que poseían en grandes plantaciones, como era la caña de azúcar o el tabaco, que requerían muchos braceros para obtener sus productos y cumplir con las metas de corte y cosecha de las zafras. También porque se requería personas interlocutoras entre los directivos de la multinacional norteamericana, los mandos medios y demás personas de jornal, y por tanto, el inglés como idioma era esencial, competencia idiomática que los trabajadores locales no poseían, con excepción de los naturales del archipiélago de San Andrés, Providencia y Santa Catalina. Esta migración nacional fue poca en comparación con los llegados de las colonias de Inglaterra, lo que en efecto originó una merma en el empleo local. Los puestos de trabajo fueron asignados a los venidos del mundo antillano, así como a los chinos, un artículo del periódico local La Voz de Santa Marta, núm. 69, en octubre 8 de 1911, muestra el desprecio a esta inmigración que se trataba de justificar públicamente de la manera siguiente:

68. El uso de cursivas en las palabras no corresponde al texto original, se usan aquí con el fin de resaltar el contenido de las mismas. 
Jorge Enrique Elías-Caro

El vapor 'Spiral', el 17 de septiembre desembarcó para la Empresa del Ferrocarril la cantidad de 18.240 durmientes para la línea. ¡Y cosa rara y anómala, nosotros con tanta exuberancia de excelentes maderas en nuestras vírgenes montañas que por falta de iniciativa y de brazos no puede aprovecharse! Cada día se palpa la necesidad de una fuerte corriente de inmigración a estas regiones; pero inmigración que no sea de negros ni de degenerados chinos que con tan poco acierto se ha ensayado hasta ahora y trata esta última de introducirse al país. ${ }^{69}$

Continuando con las explicaciones relacionadas con las estadísticas halladas sobre el proceso migratorio en sí, el otro punto de crecimiento para resaltar es el del cuatrienio 1937-1940, pero que con la aparición de la Segunda Guerra Mundial y el cese de las actividades bananeras por carecer de empresas de vapores para exportar la fruta, el negocio finalizó $y$, por ende, la producción y su comercio internacional, lo que hizo se cerraran las fincas de banano y la mano de obra que trabajaban en las áreas de cosecha (siembra, riego, fumigación, mantenimiento, limpieza de maleza, puya, entre otros), corte, empaque y transporte quedaran cesantes (Herrera, 1979). Además, los barcos de la Gran Flota Blanca de la UFCo también cesaron las operaciones para servir a la Marina norteamericana en la guerra en el suministro de alimentos, medicamentos y otros menesteres donde las tropas aliadas las necesitaran.

En la tabla 1 se detalla en forma cuantitativa el porcentaje de los migrantes antillanos que le corresponde a cada período estudiado. Así, las cifras resultantes indican que los quinquenios que recibieron mayores personas fueron los de 1926-1930 y 1936-1940, con 31,4\% y $25,7 \%$, respectivamente. Los períodos más bajos que registraron entradas fueron los de 1896-1900 y de 1911-1915, ambos con 2,9\%, pues para el período 1916-1920 no se halló en los registros consultados entrada alguna (0\%) (ver la tabla 1).

69. El uso de cursivas en las palabras no corresponde al texto original, se usan aquí con el fin de resaltar el contenido de las mismas. 
"Yumecas". West Indies workers en el enclave bananero de la United Fruit Company en el Magdalena (Caribe colombiano), 1900-1940

Tabla 1. Porcentaje de ingreso de afroantillanos entre 1896-1940

\begin{tabular}{|c|c|c|}
\hline No. & Período & Porcentaje (\%) \\
\hline 1 & $1896-1900$ & 2,9 \\
\hline 2 & $1901-1905$ & 5,7 \\
\hline 3 & $1906-1910$ & 8,6 \\
\hline 4 & $1911-1915$ & 2,9 \\
\hline 5 & $1916-1920$ & 0 \\
\hline 6 & $1921-1925$ & 5,7 \\
\hline 7 & $1926-1930$ & 31,4 \\
\hline 8 & $1931-1935$ & 17,1 \\
\hline 9 & $1936-1940$ & 25,7 \\
\hline & Total & $\mathbf{1 0 0 \%}$ \\
\hline
\end{tabular}

Fuente: Cálculos propios con base en unificación de fuentes. Archivo General de la Nación (AGN). Ministerio de Relaciones Exteriores. Fondo consulados, 1890-1940; Archivo Histórico del Magdalena Grande (AHMG), Periódico El Estado de 1921-1940, Santa Marta; AHMG, Gaceta Departamental del Magdalena, 1915-1940, Santa Marta; Biblioteca de la Universidad Cooperativa de Colombia (BUCC), Diario Oficial, 19001940, Bogotá; (BUCC) El Registro del Magdalena, 1895-1915, Santa Marta; AHMG; Fondo Cajas Departamentales. Legajos y carpetas de documentación varia, 1890-1940, Santa Marta.

Durante los períodos de recesión o de bajo movimiento migratorio, incluso la fuerza laboral importada no solo decreció desde la misma condición de ingreso de nuevas personas, sino también desde el retorno. Debido a las nuevas regulaciones implementadas, muchas de estas personas se devolvieron a su lugar de origen, o en el peor de los casos fueron deportadas. Es importante mencionar que cuando el trabajador emigraba lo hacía con toda su familia, o sea, que no era una sola persona quien migraba en los términos de lo laboral, era el seno completo del hogar. Esto generó la búsqueda de empleo en los distintos negocios conexos a las actividades bananeras o de su entramado socio-económico; me refiero a acciones comerciales, de transporte, agricultura, carpintería, zapatería, oficios varios, entre otros. 
Verbigracia de lo anterior es el caso registrado de Amy Ashwood, quien fuera la esposa del presidente de la Universal Negro Improvement Association, Marcus Garvey. Nacida en Jamaica en enero 10 de 1897, estando en edad adolescente residió en Santa Marta y en la Zona Bananera de Colombia entre 1912 y 1914 con su familia (padres y sus dos hermanos Michael y Claudius), porque sus padres Michael y Maudraine Ashwood habían llegado a trabajar en los servicios de comida o cocina de los casinos en los campamentos de los trabajadores en Prado Sevilla (plantaciones de la Zona Bananera) y el ferrocarril de la Santa Marta Railway Company. Como otras familias, ellos buscaron mejores condiciones de vida tras haber tenido serios problemas económicos en la parroquia de Puerto Antonio (Portland-Jamaica) donde residían. Antes de llegar a la Colombia bananera del Magdalena, previamente habían fracasado en un proyecto migracional en Ciudad de Panamá, donde pretendían trabajar en la construcción del canal. Una vez se estabilizaron en Santa Marta hacia 1914, Amy Ashwood y su familia administraban los restaurantes que existían en los complejos habitacionales y de oficinas de la UFCo en Santa Marta. Amy Ashwood retorna a Jamaica de manera definitiva para estudiar en el Westwood Higt School for Girls at Stewart Town, Trelawny. En el retorno se quedó en la casa de familiares de su madre. En tal estancia aprovechó para hacerse miembro de la East Queen Streen Baptist Literary and Debating Socecity y conocer allí a Marcus Garvey. Su familia residió en Santa Marta once años (Garvey, 1983, p. 74).

La migración de antillanos en Colombia no fue tan elevada si se compara con las cifras de las entradas en Cuba de braceros en el mundo azucarero que, de acuerdo con Óscar Zanetti (2008), para la década de los años veinte, de casi 4.000 en 1923 termina con aproximadamente 20.000 en 1928, casi el doble del personal que llegó a la Zona Bananera del Magdalena y Santa Marta en ese mismo quinquenio, pese a que la producción colombiana entre 1929 y 1939 —en lo referente a la economía bananera en el gran Caribe - fuera la segunda en importancia por cantidad cosechada y exportada. El promedio de la producción fue de 7.9 millones de racimos anuales, después de Honduras (19.8) y por encima de Guatemala (6.8), Costa Rica (4.5) y Nicaragua (2.9) (Elías-Caro y Vidal, 2013) (ver las gráficas $4-5$ y la tabla 2 ). 
"Yumecas". West Indies workers en el enclave bananero de la United Fruit Company en el Magdalena (Caribe colombiano), 1900-1940

Gráfica 4. Entradas de braceros en las propiedades de la UFCo en Cuba, 1923-1928

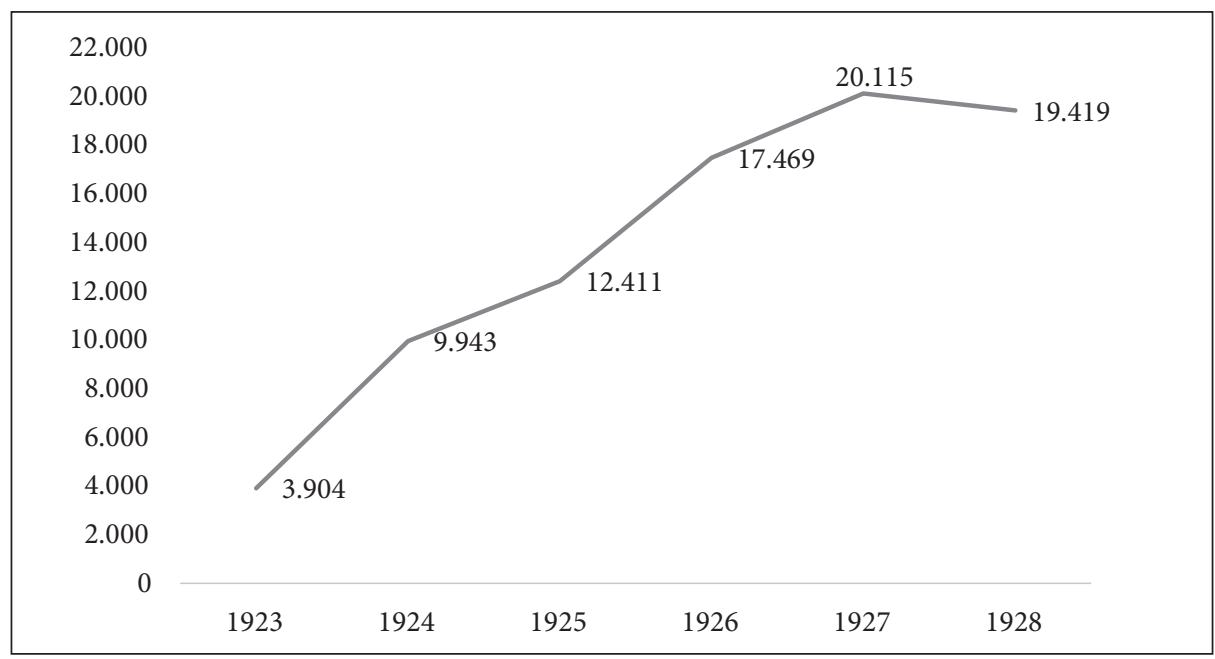

Fuente: Cálculos propios adaptados de Zanetti (2009).

Tabla 2. Exportaciones bananeras en millones de racimos en el Caribe, 1929-1939

\begin{tabular}{|c|c|c|c|c|c|}
\hline Año & Costa Rica & Guatemala & Honduras & Nicaragua & Colombia \\
\hline 1929 & 6,1 & 6,4 & 26,9 & 4,1 & 10,4 \\
\hline 1930 & 5,8 & 4,9 & 29,1 & 3,9 & 11,1 \\
\hline 1930 & 5,1 & 5,8 & 29,0 & 3,0 & 5,5 \\
\hline 1932 & 4,3 & 5,2 & 27,9 & 3,4 & 6,9 \\
\hline 1933 & 4,3 & 5,6 & 23,5 & 3,7 & 7,2 \\
\hline 1934 & 3,2 & 5,2 & 19,5 & 2,7 & 7,7 \\
\hline 1935 & 2,9 & 5,6 & 15,8 & 3,0 & 8,2 \\
\hline 1936 & 3,9 & 7,5 & 12,2 & 1,9 & 8,3 \\
\hline 1937 & 5,5 & 8,6 & 12,7 & 2,5 & 6,6 \\
\hline 1938 & 5,0 & 9,5 & 8,5 & 2,0 & 7,5 \\
\hline 1939 & 3,4 & 10,6 & 12,5 & 1,7 & 7,6 \\
\hline
\end{tabular}

Fuente: Elías-Caro y Vidal (2009). 
Gráfica 5. Exportaciones bananeras en millones de racimos en el Caribe, 1929-1939

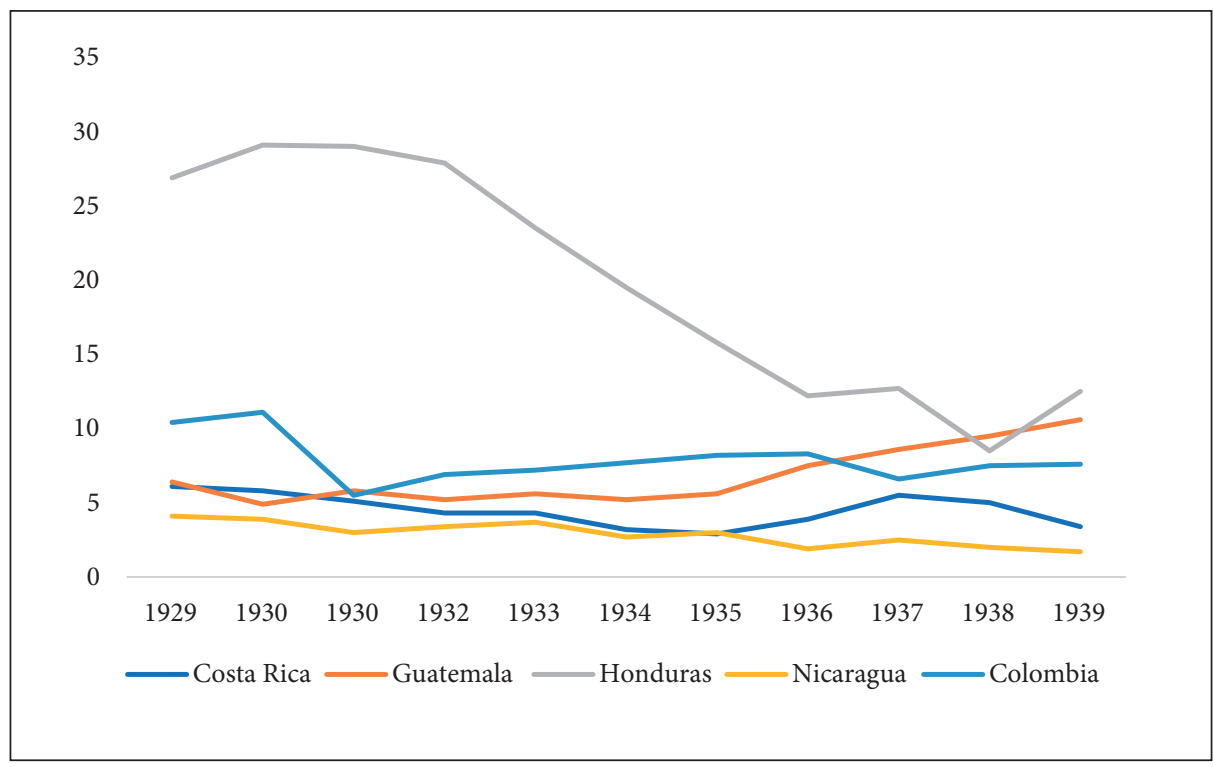

Fuente: Elías-Caro y Vidal (2009)

En lo relacionado con los lugares en donde estos se localizaron, el mayor porcentaje de residencia y trabajo fue Prado-Sevilla, con 25\%, seguido en su orden por Aracataca y Santa Marta, con 21,4\% cada uno. Los yumecas se instalaron también en algunas localidades apartadas del medio bananero, como fue Remolino, donde residió 1,8\% de estos inmigrantes. El caso de Ciénaga conviene resaltarlo porque, así como se muestra en la tabla 3, aparece solo con 5,4\%, si se detalla lo que es solamente el casco urbano de ese municipio, estando muy por debajo de otros como Orihueca $(7,1 \%)$ o a la par que Guacamayal $(5,4 \%)$. Estos espacios eran parte de la comprensión territorial de Ciénaga, ya que el municipio de Zona Bananera solo se crea en la década de los años noventa del siglo XX. Eran jurisdicciones rurales de este. La comprensión municipal completa en sí tendría un porcentaje acumulado de $44,7 \%$, siendo el centro poblado más receptor de todos, pues aparte de la cabecera municipal $(5,4 \%)$ la integraban Guacamayal, Orihueca, Pueblo Viejo (1,8\%) y Sevilla (25\%). En Fundación se instaló 10,7\% (ver la tabla 3). 
"Yumecas". West Indies workers en el enclave bananero de la United Fruit Company en el Magdalena (Caribe colombiano), 1900-1940

Tabla 3. Residencia de los trabajadores antillanos anglófonos de la UFCo, 1900-1940

\begin{tabular}{|c|c|c|}
\hline No. & Lugar de residencia & Porcentaje (\%) \\
\hline 1 & Aracataca & 21,4 \\
\hline 2 & Ciénaga & 5,4 \\
\hline 3 & Fundación & 10,7 \\
\hline 4 & Guacamayal & 5,4 \\
\hline 5 & Orihueca & 7,1 \\
\hline 6 & Pueblo Viejo & 1,8 \\
\hline 7 & Remolino & 1,8 \\
\hline 8 & Santa Marta & 21,4 \\
\hline 9 & Sevilla & 25,0 \\
\hline & Total & $\mathbf{1 0 0} \%$ \\
\hline
\end{tabular}

Fuente: Cálculos propios con base en unificación de fuentes. Archivo General de la Nación (AGN). Ministerio de Relaciones Exteriores. Fondo consulados, 1890-1940; Archivo Histórico del Magdalena Grande (AHMG), Periódico El Estado de 1921-1940, Santa Marta; AHMG, Gaceta Departamental del Magdalena, 1915-1940, Santa Marta; Biblioteca de la Universidad Cooperativa de Colombia (BUCC), Diario Oficial, 1900-1940, Bogotá; (BUCC) El Registro del Magdalena, 1895-1915, Santa Marta; AHMG; Fondo Cajas Departamentales. Legajos y carpetas de documentación varia, 1890-1940, Santa Marta.

Pese a toda esa distribución física de varios lugares donde obtuvieron su residencia por trabajo, la xenofobia hacia ellos por cuestiones raciales siguió aumentando. En el Caribe colombiano sucedió de manera similar a lo que oucrrió en Cuba, pero a escalas inferiores. El cónsul general de Colombia en La Habana envió una misiva oficial (núm 234) al ministro de Agricultura y Comercio, fechada noviembre 3 de 1921, en la que comentaba que "este mal" era fruto de esas migraciones, que debían evitarse a toda costa, máxime tras lo publicado en Cuba. Le alertaba que Colombia no podía correr el riesgo de repetir esa desacertada estrategia de aceptar a estas personas, por lo que él dentro de sus funciones había denegado el acceso al país de los "jamaiquinos" que solicitaron permiso para desplazarse al país a trabajar en las plantaciones bananeras procedente de Jamaica y de Haití. La carta del diplomático colombiano con sede en La Habana y dirigida al Gobierno central de Bogotá expresa lo siguiente: 
Jorge Enrique Elías-Caro

Número 234. La Habana, noviembre 3 de 1921. Galiano \# 26. Señor ministro de Agricultura y Comercio.

Bogotá. Señor: Con fecha 17 de octubre próximo pasado, y en nota distinguida con el número 227, tuve el honor de informar a Usted de que se habían presentado algunos jamaiquinos en solicitud del Pasaporte para poder ir a Colombia. Como tengo la completa seguridad de que ésta no podrá ser jamás una migración grata para Colombia, me he abstenido de acceder a las solicitudes. Tengo el gusto de acompañar a Ud. en corroboración de mi aserto, un suelto que al respecto publica hoy el periódico "La Noche", sobre este asunto. Con sentimientos de mi más distinguida consideración, tengo el honor de suscribirme de Usted, Su muy Atto. S. S. Jorge Saravia Márquez. Cónsul General de Colombia. ${ }^{70}$

La Noche. La Habana, octubre 1921.

Cuba necesita de este contingente exterior, porque estando aún el país en estado embrionario, ... se beneficiaría grandemente con la entrada de fuertes corrientes inmigratorias, que vinieran a trabajar nuestras tierras incultas... Guardan con nosotros nexos íntimos, por razones de sangre, de idioma, de costumbres, de religión, de tradiciones, y que pueden, en consecuencia, aliarse con el elemento nativo, sin que esta sufra, por ello, perjuicios notorios.

No pasa lo mismo con otra suerte de inmigrantes: Por ejemplo, los haitianos y jamaiquinos que están separados de nosotros por muchos motivos y cuya entrada en el país es profundamente dañina para nuestros intereses étnicos, y aún desde otros puntos de vista que recaban nuestra atención. Es, asimismo, urgente e indispensable, que se tomen medidas eficientes en tal sentido, a fin de que se ponga un dique a dichas corrientes inmigratorias, impidiendo que se introduzcan en el país más jamaiquinos, haitianos y todo ese elemento de fuera que es, verdaderamente, un elemento pernicioso. ${ }^{71}$

70. Archivo General de la Nación (AGN). Bogotá. Sección República, Fondo Baldíos. Tomo 48, folio 489.

71. Archivo General de la Nación (AGN). Bogotá. Sección República, Fondo Baldíos. Tomo 48, folio 489 . 
"Yumecas". West Indies workers en el enclave bananero de la United Fruit Company en el Magdalena (Caribe colombiano), 1900-1940

El ejemplo de lo sucedido en Cuba fue suficiente para que el Gobierno colombiano tomase medidas en contra de la entrada de trabajadores afroantillanos. Lo que emite al respecto el Ministerio de Agricultura y Comercio para evitar que los antillanos trabajen en las plantaciones bananeras del Magdalena es el siguiente texto:

Ministerio de Agricultura y Comercio. - Sección 3a.- Bogotá, diciembre 9 de 1921. Acúsese atento recibo. Dígase al Sr. Cónsul General de Colombia en La Habana, que el suscrito aplaude el interés que ha tenido ese Consulado para no permitir que venga a este país una inmigración tan perniciosa como la de los jamaiquinos ${ }^{72}$... Por el ministro, el secretario, Firmado. Simón López A.

Todas estas prohibiciones fueron comunicadas a los medios locales, los cuales inmediatamente hicieron conocer al público en general. Fuera de eso, los periódicos La Voz de Santa Marta, Ecos del Magdalena del municipio de Ciénaga y el naciente El Estado para 1921 difunden la nota de prensa que fue publicada en La Noche de La Habana. La idea de esta comunicación escrita era promover colectivamente el desinterés hacia la migración de afroantillanos "porque traían problemas sociales y económicos a la región" y a la misma sociedad samaria y magdalenense. Plantea que debe promoverse la inmigración europea y de blancos como lo ha hecho Argentina, en la que como país ha pregonado regulaciones que benefician este tipo de intercambio humano en pro de alcanzar beneficios, desarrollo y riquezas económicas, pues vienen a trabajar "sanamente" la tierra "inculta" para "civilizarla", a hacer inversiones, montaje de fábricas e industrias y crear empresas. Se debe impulsar los nexos culturales, en especial los del idioma español, las religiosidades, tradiciones y costumbres, ligados al catolicismo y otras prácticas culturales heredadas desde España.

Por el contrario, se insistió en los perjuicios que ocasionaría la migración de afronatillanos, fruto de las diferencias idiomáticas, por asuntos étnicos y por expresiones y saberes culturales muy distintos, Los discursos llegaron incluso a tratarlos de salvajes, incultos y de practicar rituales

72. El uso de cursivas en las palabras no corresponde al texto original, se usan aquí con el fin de resaltar el contenido de las mismas. 
Jorge Enrique Elías-Caro

caníbales debido a ceremonias satánicas y de brujería. Todo ellos motivaba que se considerasen "elementos perniciosos" que debían evitarse. El artículo de prensa que difundieron estos periódicos justamente tenía por título "Elemento pernicioso" y dice así:

Elemento Pernicioso. Desde hace mucho tiempo nos venimos ocupando del problema inmigratorio, por considerarlo de gran importancia para nosotros. Todo el mundo sabe el interés que tiene para un país en formación todavía, como el nuestro, abrir amplio cauce a las corrientes inmigratorias, desde el instante en que ellas constituyen un factor de progreso indiscutible, impulsando el desarrollo de la riqueza pública, y contribuyendo poderosamente al adelanto material y a la prosperidad económica. Naciones hay que, como la Argentina, dándose cuenta exacta de este problema, ha establecido una legislación especial, para favorecer, con medidas juiciosas y atinadas, las corrientes de inmigrantes, que allí acuden incesantemente, en busca de los beneficios que les brinda el Estado, prestándoles, al mismo tiempo, amparo y protección.

Cuba necesita de este contingente exterior, porque estando aún el país en estado embrionario, con respecto a muchas de nuestras actividades, se beneficiaría grandemente con la entrada de fuertes corrientes inmigratorias, que vinieran a trabajar nuestras tierras incultas, sobre todo, pues la industria agrícola, como fuente inagotable de riqueza, está muy poco explotada y requiere una asidua dedicación. Ahora bien, tenemos que significar, referente a este asunto, que no nos convienen todas las inmigraciones. Sino las que, como la española, en primer grado, guardan con nosotros nexos íntimos, por razones de sangre, de idioma, de costumbres, de religión, de tradiciones, y que pueden, en consecuencia, aliarse con el elemento nativo, sin que éste sufra, perjuicios notorios.

No pasa lo mismo con otra suerte de inmigrantes: por ejemplo, los haitianos y jamaiquinos, que están separados de nosotros por muchos motivos y cuya entrada en el país es profundamente dañina para nuestros intereses étnicos, y aún desde otros puntos de vista que recaban nuestra atención.

Así hoy, están ocurriendo hechos escandalosos promovidos por ese elemento pernicioso. En Guantánamo uno de esos negros, siguiendo sus prácticas canibalescas, mató hace pocos días a un niño y luego lo devoró. 
"Yumecas". West Indies workers en el enclave bananero de la United Fruit Company en el Magdalena (Caribe colombiano), 1900-1940

Y este no es un caso aislado, sino que se repite con frecuencia alarmante este género de brujería, revelante del salvajismo más atroz.

Es, por tanto, de absoluta necesidad, que nuestras autoridades persigan severamente a los autores de estas barbaridades y procedan contra ellos con extremo rigor, llevando el escarmiento a los de más, para que no sigan aconteciendo tales crímenes en el seno de un país culto y civilizado como el nuestro, debidos a esas inmigraciones perjudiciales que se nos han colado en nuestro territorio, y que nos hacen mucho daño, por todos conceptos.

Es, asimismo, urgente e indispensable, que se tomen medidas eficientes en tal sentido, a fin de que se ponga un dique a dichas corrientes inmigratorias, impidiendo que se introduzcan en el país más jamaiquinos, haitianos, y todo ese elemento de fuera que es verdaderamente, un elemento pernicioso.

\section{Las familias yumecas. Características}

Fueron varias las familias British West Indies que llegaron a laborar y se quedaron. Lo hicieron de diversas maneras, procedentes de diferentes islas y se instalaron en varias partes de la geografía regional del departamento del Magdalena. Tal como se evidenció en las tablas y gráficas anteriores, Jamaica fue el país que exportó más migrantes. En la tabla 4 se hace alusión a las familias provenientes de Jamaica, Granada, Santa Lucía y Trinidad y Tobago, referenciando los apellidos y el lugar en donde se instalaron, entre los que están: Santa Marta, Prado Sevilla, Fundación, Aracataca, Pueblo Viejo, Remolino, Orihueca, Bonda y Guacamayal.

Tabla 4. Relación de familias "yumecas", procedencia y residencia.

\begin{tabular}{|c|c|c|}
\hline Familia & Procedencia & Residencia \\
\hline Andrews & Granada & $\begin{array}{c}\text { Sevilla, Santa Marta, } \\
\text { Fundación y Aracataca }\end{array}$ \\
\hline Bislick & Jamaica & Ciénaga y Fundación \\
\hline Blades & Santa Lucía & Santa Marta \\
\hline Cambell & Granada & Sevilla y Aracataca \\
\hline
\end{tabular}


Jorge Enrique Elías-Caro

\begin{tabular}{|c|c|c|}
\hline Familia & Procedencia & Residencia \\
\hline Daschner & Trinidad y Tobago & Fundación \\
\hline Dewney & Granada & Ciénaga y Santa Marta \\
\hline Donovan & Jamaica & Aracataca \\
\hline Douglas & Jamaica & Santa Marta \\
\hline Downey & Granada & $\begin{array}{c}\text { Ciénaga - Sevilla y } \\
\text { Guacamayal }\end{array}$ \\
\hline Dudley & Jamaica & Orihueca - Sevilla \\
\hline Hawkins & Jamaica & Santa Marta - Bonda \\
\hline Henry & Jamaica & Santa Marta \\
\hline Hopkins & Jamaica & Santa Marta - Pueblo Viejo \\
\hline Johnson & Jamaica & Santa Marta - Ciénaga \\
\hline Joseph & Granada & Santa Marta y Aracataca \\
\hline Joseph & Trinidad y Tobago & Aracataca \\
\hline Leds & Jamaica & Orihueca - Sevilla \\
\hline McFallings & Jamaica & Orihueca \\
\hline McKingston & Jamaica & Orihueca - Sevilla \\
\hline Moss & Jamaica & Fundación \\
\hline Nowel & Jamaica & Sevilla \\
\hline Obbid & Jamaica & Santa Marta \\
\hline Oliwe & Jamaica & Aracataca \\
\hline Owen & Jamaica & Fundación \\
\hline Penny & Granada & Santa Marta \\
\hline Reid & Jamaica & Aracataca \\
\hline Robinson & Jamaica & Aracataca \\
\hline
\end{tabular}


"Yumecas". West Indies workers en el enclave bananero de la United Fruit Company en el Magdalena (Caribe colombiano), 1900-1940

\begin{tabular}{|c|c|c|}
\hline Familia & Procedencia & Residencia \\
\hline Rosemberg & Granada & $\begin{array}{l}\text { Sevilla, Santa Marta, } \\
\text { Fundación y Aracataca }\end{array}$ \\
\hline Rudolf & Jamaica & Ciénaga y Guacamayal \\
\hline Russel & Jamaica & $\begin{array}{c}\text { Santa Marta, Guacamayal } \\
\text { y Aracataca }\end{array}$ \\
\hline Scott & Granada & Santa Marta y Ciénaga \\
\hline Simmonds & Jamaica & Sevilla y Remolino \\
\hline Stenver & Jamaica & Guacamayal \\
\hline Steward & Jamaica & Sevilla \\
\hline Taitte & Jamaica & Sevilla y Santa Marta \\
\hline Thomas & Granada & $\begin{array}{c}\text { Guacamayal, Ciénaga } \\
\text { y Santa Marta }\end{array}$ \\
\hline Thompson & Jamaica & $\begin{array}{c}\text { Santa Marta, Pueblo Viejo } \\
\text { y Aracataca }\end{array}$ \\
\hline Timms & Jamaica & $\begin{array}{l}\text { Ciénaga, Fundación y } \\
\text { Santa Marta }\end{array}$ \\
\hline Tripton & Jamaica & Sevilla \\
\hline Verdey & Santa Lucía & Santa Marta y Aracataca \\
\hline Webber & Granada & Sevilla y Santa Marta \\
\hline Widol & Jamaica & Sevilla \\
\hline Yons & Granada & Aracataca \\
\hline Zimmerman & Jamaica & Sevillla \\
\hline
\end{tabular}

Fuente: Archivo General de la Nación (AGN). Ministerio de Relaciones Exteriores. Fondo consulados, 1890-1940; Archivo Histórico del Magdalena Grande (AHMG), Periódico El Estado de 1921-1940, Santa Marta; AHMG, Gaceta Departamental del Magdalena, 1915-1940, Santa Marta; Biblioteca de la Universidad Cooperativa de Colombia (BUCC), Diario Oficial, 1900-1940, Bogotá; (BUCC) El Registro del Magdalena, 1895-1915, Santa Marta; AHMG; Fondo Cajas Departamentales. Legajos y carpetas de documentación varia, 1890-1940, Santa Marta. 
Jorge Enrique Elías-Caro

Por su parte, en la tabla 5 se reproduce un amplio listado de apellidos yumecas que aparecen registrados como colombianos y que entraron supuestamente como sanandresanos o providencianos. Estos para trabajar en diversas actividades en los puertos marítimos de Santa Marta y Ciénaga, en las diferentes estaciones del ferrocarril de Fundación, Aracataca, Ciénaga y Santa Marta y los diferentes ramales en las plantaciones de la Zona Bananera, como también en los comisariatos, actividades de producción bananera y supervisión de servicios varios, en la construcción de casas, oficinas, bodegas e instalaciones de la UFCo, así como en negocios particulares (ver la tabla 5).

Según lo hallado en los escasos registros que existen, estos supuestos sanandresanos o providencianos que entraron a la zona bananera lo hicieron por el mismo puerto de Santa Marta, por el embarcadero de Ciénaga procedente en escala de Barranquilla o entrando directamente también por Riohacha y después llegaban a Santa Marta y a la misma región bananera. Las autoridades bloquearon su entrada tras descubrir que eran jamaicanos que habían utilizado las islas colombianas como mecanismo de ruta de entrada o trampolín para luego hacerse pasar como nacionales y no les exigieran el pasaporte de ingreso; por su parte, los trinitarios, tobaguenses y barbadenses en su mayoría entraron de manera clandestina por Riohacha y el resto de las costas marítimas del departamento de La Guajira, aprovechando la cercanía existente con el vecino país Venezuela, por donde entraban en primera instancia y de allí pasaban a Colombia por vía terrestre.

También existen registros de estos migrantes entrando desde $\mathrm{Cu}$ razao y Aruba. Después de llegar de Jamaica, Trinidad y Tobago, Barbados, Granada, Santa Lucía y demás islas británicas del Caribe a estas islas de Países de Bajos, se dirigían a Santa Marta o Riohacha, ya que estos espacios holandeses y los puertos colombianos desde el siglo XVIII siempre habían mantenido un tráfico comercial y portuario fluido entre ellos. 
"Yumecas". West Indies workers en el enclave bananero

de la United Fruit Company en el Magdalena (Caribe colombiano), 1900-1940

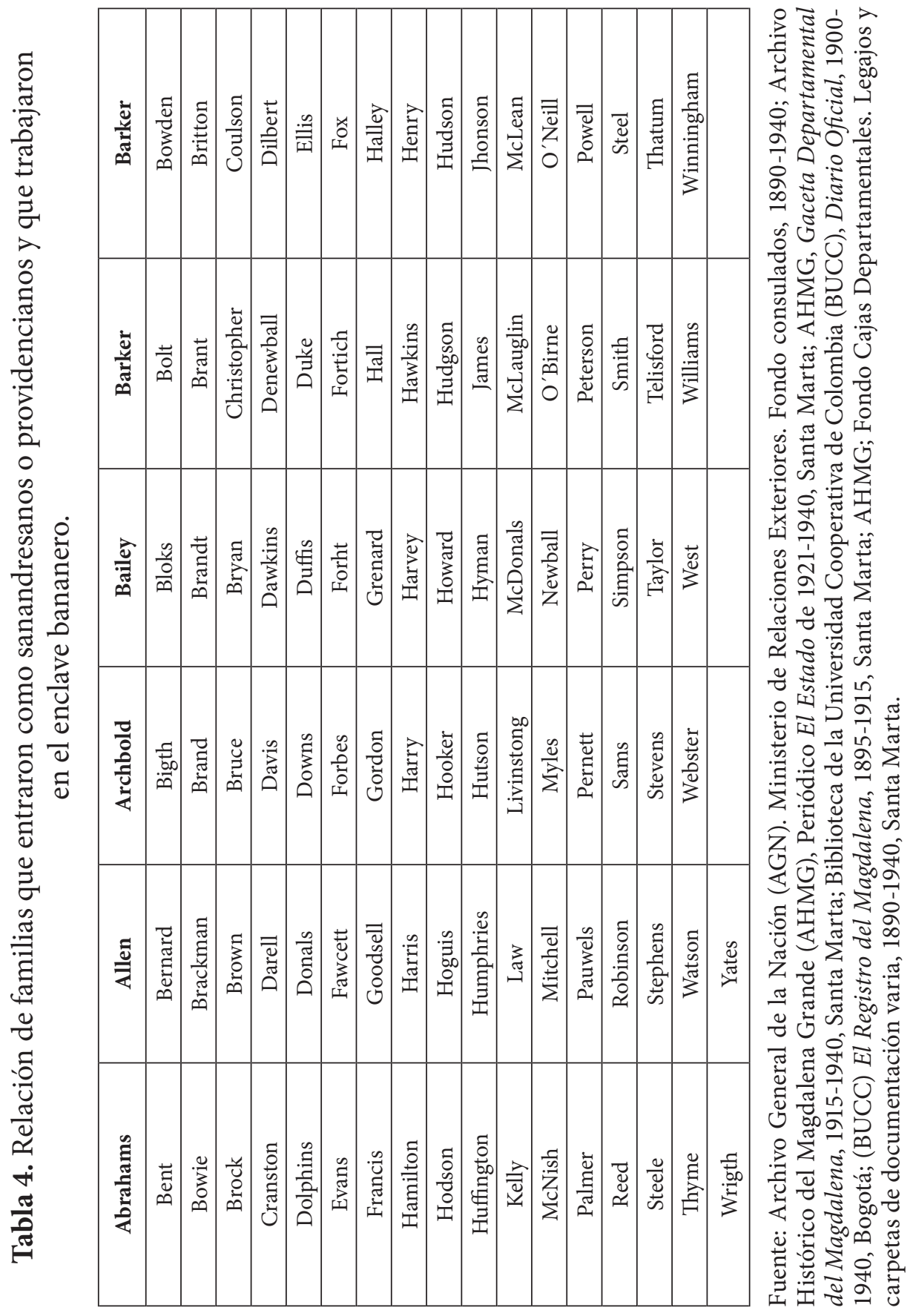


Jorge Enrique Elías-Caro

El intercambio con estas islas atemperaba en cierta medida los conflictos sociales que se habían suscitado por estas migraciones, y como no había precaución ni restricciones ante los procedentes de Aruba o Curazao, pues sencillamente vieron estas rutas como mecanismo sustancial de ingreso. Las regulaciones para limitar e impedir su ingreso y exigencia de visado en el pasaporte estaban dadas solo para jamaicanos, trinitarios, tobaguenses granadinos y barbadenses, mas no para curazaleños, arubeños, dominicanos o puertorriqueños. De ahí que para poder entrar a Colombia se hicieran pasar como poseedores de estas nacionalidades.

\section{Consideraciones finales}

Uno de los determinantes económicos y sociales que más implicaron que se promovieran las migraciones laborales en las plantaciones bananeras de la UFCo en la Zona del Magdalena fue lo concerniente al idioma inglés, puesto que esa era la lengua oficial que estos "blacamanes" hablaban y los dirigentes de la multinacional empleaban al ser la lengua materna de ellos, ya que eran de nacionalidad estadounidense o procedían de los países de influencia británica. Como es lógico en jerarquías y estructuras sociales y laborales desde una perspectiva de integración horizontal o vertical, requerían comunicarse con otros, y por ello era indispensable hacerlo en su idioma. Aspecto este que los locales no hacían, pues solo hablaban castellano y no tenían la competencia de hablar una segunda lengua, de ahí que se vieran abocados a importar esa mano de obra. Los trabajadores eran utilizados en las actividades de la plantación (cosecha, siembra, corte, empaque, limpieza, entre otras), así como en las derivadas de esta actividad agrícola, del transporte en todos sus medios (carretera, puertos fluviales y marítimos y el ferrocarril), el comercio en general, la construcción de obras civiles (bodegas, oficinas, instalaciones de la multinacional, residencia de directivos y trabajadores) e incluso en servicios profesionales varios como abogados, médicos, contadores públicos y arquitectos, así como técnicos especializados en zapatería, sastrería, talabartería, carpintería, soldadura y otras artes y oficios ejercidos por ellos. Por todo esto, se les permitió incursionar en diversos negocios y actividades del "enclave" bananero (cultivos de la fruta, tren, puertos, mantenimiento 
"Yumecas". West Indies workers en el enclave bananero

de la United Fruit Company en el Magdalena (Caribe colombiano), 1900-1940

de vías e infraestructura, venta de mercancías, agricultura y ganadería) una vez la multinacional suspende operaciones en 1941 por el inicio de la Segunda Guerra Mundial y el uso de sus embarcaciones - adscritas a la Gran Flota Blanca - al suministro de alimentos para el abastecimiento de las tropas aliadas y el transporte de pertrechos e insumos militares.

Un aspecto que hizo que, en convivencia entre ellos, al estar unidos y proceder de las colonias de Inglaterra en el Caribe, jocosamente en ambientes culturales y familiares para contrarrestar la xenofobia hacia ellos enfatizaban que era porque se trataba de "sires" y dignos representantes del Imperio británico al servicio de Su Majestad, la reina. El asunto de lo anglófono incidió en presentar una relación más estrecha con los directivos de la UFCo. Además, porque muchos habían estudiado en las mejores universidades o colleges de Inglaterra y Estados Unidos, y por ello ostentaban cargos de mejor jerarquía. En su mayoría eran supervisores.

Por tanto, a nivel directivo y de mando medio, así como en ciertas actividades del encadenamiento productivo, estos migrantes negros provenientes de las Antillas británicas fueron una fuerza laboral predominante y desde el punto de vista tecnológico generaron transferencia de conocimientos (enseñanzas-aprendizajes) y no solo del contexto bananero y sus relaciones económicas, sino de sus aspectos sociales y culturales, ya que coadyuvaron a la conformación de tejidos productivos en el territorio. La creación de estos entramados socioeconómicos y cultuales provocó que no fueran actores marginales en los procesos, máxime que se vincularon y adaptaron a la cotidianidad del campo y la vida rural, pero también en ámbitos urbanos. Residieron en los pueblos en convivencia con el resto de trabajadores. Pocos fueron los que se devolvieron (echaron raíces muy prolijas) y su descendencia fue parte de la dirigencia política, gubernamental, social y gremial de la región.

Su llegada tuvo varios condicionantes en términos laborales, de nuevos puestos de trabajo originados, de creación de empresas y aspectos de ingresos y mejoramiento de los niveles de calidad de vida de la población. No obstante, su llegada se da como una solución para abaratar la mano de obra, debido a que las condiciones en que vivían en las islas en términos económicos eran inferiores a las que tendrían en tales plantaciones. Todo esto originó rechazo social, que más allá de lo propiamente dicho acerca del empleo con estas migraciones estaba lo racial, y más por la jerarquía 
Jorge Enrique Elías-Caro

en el cargo que tendrían y conocimientos que poseían. No aceptaban que un black man los mandara o les diera órdenes.

Sin embargo, al entrar estas cantidades de yumecas o blacamanes a los territorios del Magdalena, luego de cuatro décadas, estas culturas se mezclaron. Las costumbres, religiosidades, sincretismos, expresiones artísticas (música, danzas, plásticas, literatura) y prácticas culturales (gastronomía, fiestas, festivales, artesanías, etc.) con el tiempo generaron aportes sociales y legados culturales que hoy aún se mantienen vigentes. Mantenían relaciones interpersonales muy cerradas (reuniones exclusivas del grupo anglosajón). Muchos incursionaron en la masonería (fueron promotores de varias logias, entre ellas las de Aracataca, Ciénaga y Santa Marta), tenían cultos propios y rituales en fiestas familiares, sobre todo con prácticas religiosas y de trato muy común entre ellos (denominación a los paisanos como: hermano, tío, sobrino y primos), lo que originó animadversión en la población local al darse la "satanización" de lo negro (ligado a la brujería, santería, vudú o ritos malignos) e ir en contra de los principios cristianos, como bien lo pudimos ver en algunos apartes de este trabajo.

De ese listado de apellidos muchos descendientes de estos se han destacado en diversos ámbitos. Ejemplo de ellos está el cantante panameño Rubén Blades, puesto que su padre nace en Santa Marta fruto de la unión de una persona procedente de la isla de Santa Lucía, quien llegó a trabajar en el puerto y el ferrocarril, y una nativa de la ciudad. Muchos futbolistas de talla internacional, que han sido nietos y bisnietos de estos yumecas han destacado a nivel mundial, es el caso de Radamel Falcao García. Así los yumecas, esos blacamanes que llegaron con la Yunai-dentro del proceso migratorio que se suscitó por varios años- lo hicieron no solo para trabajar sino para quedarse y buscar mejores oportunidades de vida y dejar con ello su cultura y legado que hoy en muchas expresiones aún se mantienen.

\section{Referencias}

Aponte, M. (2011). La historia del Vallenato. Discursos hegemóni$\cos y$ disidentes (Tesis de maestría, Pontificia Universidad Javeriana, Bogotá, Colombia). Recuperada de https://repository.javeriana.edu. co/bitstream/handle/10554/1630/AponteMantillaMariaEmilia2011. pdf? sequence $=1$ \&isAllowed $=y$ 
"Yumecas". West Indies workers en el enclave bananero

de la United Fruit Company en el Magdalena (Caribe colombiano), 1900-1940

Cavelier, G. (1997). Política Internacional de Colombia 1903-1953 (t. 3). Bogotá: Universidad Externado de Colombia.

Donadio, A. (2002). La guerra con el Perú. Medellín: Hombre Nuevo Editores.

Elías-Caro, J. y Vidal Ortega, A. (2012). The worker's massacre of 1928 in the Magdalena Zona Bananera - Colombia. An unfinished story. Memorias, 9(18), Barranquilla: Universidad del Norte, 22-54.

Elías-Caro, J. y Vidal Ortega, A. (2013). Multinacionales bananeras e imperio económico en el gran Caribe: 1900-1942. Revista Escuela de Historia, 12(2), 1-26.

Garay, C. (2009). El atributo amazónico del Perú. La construcción de una soberanía, 1903-1942. Historia Crítica, 39, 108-129.

García Márquez, G. (2013). Blacamán el bueno vendedor de milagros. Esto es puro cuento. Veracruz: Universidad Veracruzana, 1-5.

Garvey, M. (1983). The Marcus Garvey and Universal Negro Improvement Association Papers (vol. 1). Kingston, Robert A. Hill.

Henderson, J. (2001). Modernization in Colombia: The Laureano Gomez Years, 1889-1965. Gainesville: University Press of Florida.

Herrera R. (1979). La zona bananera del Magdalena: historia y léxico. Bogotá: Instituto Caro y Cuervo.

Insanally, A. (ed.). (2004). The Socio-Economic and Cultural Impact of West Indian Migration to Colombia. Kingston: UWI Latin American Caribbean Centre.

James, W. (1998). Holding Aloft the Banner of Ethiopia: Caribbean Radicalism in Early Twentieth Century America. Londres: Verso Press.

Ospina, M. (2006). Guerra del Amazonas (Colombia-Perú: 1932-1933). Portal Caballeros Andantes. Recuperado de http://mundosgm.com/smf/index. php?topic $=5590.0$;wap2

Piquería: un duelo de música y palabras (1999, 30 de abril). El Tiempo. Recuperado de https://www.eltiempo.com/archivo/documento/MAM-920635

Presidencia de la República de Colombia (s. f.). General Rafael Reyes Prieto. 19041909. Recuperado de http://historico.presidencia.gov.co/asiescolombia/presidentes/39.htm

Rey, É. (2006). Cristo Rey: un espacio para permanecer en el tiempo. Barranquilla: Cooperativa Editorial Magisterio.

Uribe, T. (2013). Caucho, explotación y guerra: configuración de las fronteras nacionales y expoliación indígena en Amazonía. Memoria y Sociedad, 17(34), 34-48.

Valencia, Á. et al. (2001). Conflicto Amazónico 1932/1934. Bogotá: Villegas Editores. 


\title{
En sintonía con los tiempos: perfil ocupacional y división sexual del trabajo de la población afrocaribeña en Costa Rica durante la primera mitad del siglo XX
}

\author{
Diana Senior Angulo \\ Universidad de Costa Rica
}

\section{Introducción}

Las poblaciones que migran hacia Costa Rica procedentes del Caribe hacia finales del siglo XIX lo hacen en una época de reconocido desplazamiento y movilidad laboral internacional en términos económicos. Su importancia fue central para el desarrollo no solo económico-productivo, sino social y cultural del país en el que terminaron estableciéndose. Para entender su incursión colectiva, así como la segmentación del contingente laboral que, en diferentes oleadas, se establece inicialmente en la provincia de Limón, se ha elegido analizar sus implicaciones propias desde la perspectiva de la división sexual del trabajo, la cual formó parte de la oferta laboral ofrecida y asumida por mujeres y hombres afrocaribeños entre finales del siglo XIX y durante la primera mitad del siglo XX. Esto permitirá vincularlo con las relaciones humanas establecidas tanto dentro como fuera de los hogares, para luego particularizar sobre los oficios segmentados en sintonía con los tiempos que, en última instancia, fueron parte de las decisiones para el desempeño productivo escogido por las mujeres y los hombres afrocaribeños hacia mediados del siglo XX. 
En sintonía con los tiempos: perfil ocupacional y división sexual del trabajo de la población afrocaribeña en Costa Rica durante la primera mitad del siglo XX

\section{Segmentación migratoria y laboral de las poblaciones afrocaribeñas a partir de finales siglo XIX}

Especialistas en historia económica denominaron "primera ola de globalización" al período de libre comercio y libre movilidad del capital en la economía mundial que se extendió, aproximadamente, de 1870 a 1913. Este tiempo se caracterizó también por amplias corrientes migratorias internacionales, lo que le valió su denominación como "era de la migración masiva" (Solimano, 2003, p. 57; Senior, 2011, p. 3). Dichas migraciones ayudaron no solo a la construcción de obras de infraestructura y al sostenimiento de sectores específicos de las economías de los países receptores, sino que llegaron a conformar y reconstituir en términos generales a las sociedades en las que se establecieron las poblaciones inmigrantes; al mismo tiempo que estas continuaron proveyendo de manera tangible a los lugares de procedencia (Senior, 2011, pp. 3-4). Quienes anteriormente habían sido pequeños cultivadores llegaron a engrosar el número de pobres en Kingston, Jamaica, y este fue el milieu que proveyó a los primeros reclutas afrocaribeños para los contratistas estadounidenses, que buscaban una fuerza de trabajo desplazable con miras a la construcción de proyectos en el istmo centroamericano (Putnam, 2002, p. 30; Senior, 2011, p. 8).

Es, en este contexto, donde ocurren sistemáticas oleadas migratorias, la primera y más importante relacionada con la construcción del ferrocarril en Panamá para la década de 1850, en ese momento parte de Nueva Granada. Gran cantidad de jamaiquinos, fundamentalmente hombres afrocaribeños, fueron desplazados a esta zona para cumplir con las labores propias de dicha obra de infraestructura (Putnam, 2002, pp. 36-37; Senior, 2011, p. 10). Aunque los trabajadores vinieron del extranjero y los contratistas recorrieron exhaustivamente distintos lugares del área circunvecina para dicho fin, la evidencia demuestra que la mano de obra vino sobre todo de las llanuras de Jamaica y Macao. En abril de 1874, unos 2.500 hombres estaban trabajando: 1.000 eran negros de Jamaica, 500 eran chinos y la nacionalidad de los otros 1.000 no se mencionaba. Se sugiere que estos últimos eran costarricenses del Valle Central (Koch, 1966, pp. 63-64; Senior, 2011, pp. 11-13). Poco tiempo después, la línea del tren estaba rodeada por viviendas afrocaribeñas 
y, años más tarde, Puerto Limón contaba con una población de alrededor de 1.000 habitantes. Por política de la compañía (la United Fruit Company, en adelante UFCo., de sus siglas en inglés), dichos domicilios alojaban pocas mujeres, por lo que, en las subsiguientes décadas, las áreas rurales de Limón se mantendrían predominantemente masculinas. Sin embargo, las mujeres paulatinamente "vinieron de las colonias británicas isleñas, así como de poblados en las costas colombiana y nicaragüense principalmente; viajando mucho al igual que los hombres y frecuentemente con el fin de reunirse con los suyos" (Putnam, 2002, p. 43; Senior, 2011, p. 12). Por ello, desde un inicio, parte de la fuerza de trabajo fue completamente segregada, los negros trabajando desde el interior de la costa y los chinos en cinco campamentos entre Cartago y Fajardo. Además, dentro de la estructura de la fuerza de trabajo existieron estratificaciones de tipo sociocultural entre los diferentes grupos humanos (Chomsky, 1996, p. 24; Senior, 2011, p. 14). Sin embargo, tanto el campesinado jamaiquino como el Gobierno costarricense iniciaron el negocio bananero: este último pagando por el ferrocarril, mientras que los primeros demostrando que la exportación de banano podía crecer a lo largo de la vía férrea (Koch, 1966, p. 83; Marquardt, 2001, p. 16; Senior, 2011, p. 19).

Previo a esta época, en la zona ya se habían producido diversos cultivos, entre ellos: café, banano, cacao, plátano, yuca, abacá, piña, maíz, caucho y coco. De cualquier forma, todos menos el banano, el cacao y el maíz, habían sido de inmensa importancia local, aparte de que fueron producidos durante pocos años (Koch, 1966, p. 85; Senior, 2011, p. 19). No obstante, el gobernador de Limón, don Balvanero Vargas, anotó dos problemas que caracterizarían a la industria bananera en los años por venir y que causarían conflictos significativos en las comunidades costeras. El primero se relacionaba con el control adquirido por la compañía del ferrocarril en virtud de su monopolio en el transporte y la comercialización de la fruta; mientras que, en segundo lugar, Vargas observó que la mayoría de los hacendados se quejaban de la escasez de trabajadores, estimando que el aumento de la agricultura en esta zona no tomaría proporciones colosales si dicha dificultad persistía (Senior, 2011, pp. 19-20). 
Un asunto que preocupaba al Congreso costarricense era que los empresarios, quienes habían emprendido las siembras de café, cacao y banano, se arruinaran por la falta de trabajadores disponibles. En ese sentido, en 1896, un ciudadano propuso que el Estado patrocinara programas de inmigración en vez de dejarlo en las manos de las compañías privadas. Una de las ventajas señaladas por el autor del proyecto se refería a que, si los trabajadores venían de diversos lugares, no tendrían homogeneidad de origen y se evitarían posibles huelgas (Senior, 2011, p. 20). En 1904, la United Fruit reportó 5.600 trabajadores en su planilla de la División de Limón, de los cuales 4.000 eran jamaiquinos. Empero, distintos agricultores de la United Fruit produjeron 54\% de los bananos exportados desde Limón en ese mismo año, en extensas plantaciones propiedad de adinerados costarricenses y otros dueños, situadas en las inmediaciones de Siquirres, Parismina y más arriba de la Línea Vieja (Chomsky, 1996, p. 60; Putnam, 2002, pp. 59-60; Senior, 2011, p. 20).

Aunque el primer auge bananero alcanzó su cúspide en 1907, ya en 1912 el primer declive estaba en camino. Las estadísticas de exportación muestran una cierta estabilidad entre 1907 y 1913, pero en realidad la pendiente había iniciado en 1908. En ese año, comerciantes y productores de banano se quejaban aduciendo que la economía provincial estaba en decadencia y que, a consecuencia directa, el desarrollo de la ciudad de Limón se vería particularmente estancado. El "mal de Panamá" fue su ignición, pero el involucramiento de Estados Unidos en la Primera Guerra Mundial contribuyó claramente en la baja productiva; por tanto, el declive de las plantaciones bananeras, hondamente pronunciado después de 1913, estuvo acompañado de una masiva reorientación hacia el cultivo de cacao. Al igual que con el banano, el Gobierno costarricense subsidió la industria cacaotera hasta su establecimiento (Casey, 1979; pp. 177-178; Putnam, 2002, pp. 45, 48; Koch, 1966, pp. 134-140, 147, 151, 166; Senior, 2011, p. 20).

Entre 1908 y 1914, no hubo un cambio en la tendencia de las exportaciones de cacao, solo fluctuaciones inducidas aparentemente por el clima; por ejemplo, de 1909 a 1910, el año estuvo caracterizado por la humedad. Esto correspondió también a una falta de plantaciones significativas entre 1903 y 1909, debido al auge bananero o al activo reclutamiento de trabajadores para la construcción canalera en Panamá (Koch, 
1966, p. 168; Senior, 2011, pp. 20-21). En el curso de esta situación, se permitía que los afrocaribeños viajaran libremente dentro y fuera de la zona bananera. Mientras que de 1900 a 1913 emigraron a Costa Rica unos 20.000 jamaiquinos, junto a un número mucho más reducido de otros afrocaribeños (Casey, 1979, pp. 126-127; Senior, 2011, p. 21).

Desde 1915, el porcentaje de la exportación cacaotera había estado en constante expansión, con un marcado aumento después de 1918. En 1913, los jamaiquinos propietarios de cacao tenían 7,6\% del total de las tierras dedicadas a dicho producto y en 1925, apenas $1,37 \%$, ya que los bajos precios hicieron al cacao improductivo después de 1924; así se explica el declive en sus exportaciones hacia 1930. Además, parte de la razón, indica Palmer (2000), radica en que los negros jamaiquinos fueron los que con mayor frecuencia perdieron sus propiedades mediante los sistemas de crédito existentes en la época, propiedades que fueron a caer en manos de particulares y de bancos comerciales; porque gracias a las altas tasas de interés, muchas fincas fueron rematadas. Sin embargo, esta participación afrocaribeña tan activa alrededor del cacao, aunque estimulada fundamentalmente por la UFCo., fue una reminiscencia de la economía campesina de los pequeños agricultores de finales del siglo XIX (Koch, 1966, pp. 168, 196; Quesada, 1977, pp. 75, 95-96; Palmer, 2000, pp. 303-304; Senior, 2011, p. 21).

Lo anterior explicaría el hecho de que el comercio fuera una actividad importante. Y que, por ejemplo, en el Censo Comercial de la República de Costa Rica, compilado para efectos tributarios en 1915, se estableciera que los jamaiquinos (incluidos bajo la categoría de "inglés") poseyeran negocios a lo largo de la Línea Principal, en la región más vieja de establecimiento de la población negra (Cahuita y Puerto Viejo) y en la baja Línea Vieja. Por ello, cuando ocurre el auge expansivo en los distritos de Talamanca y Sixaola (1910-1920), la UFCo. permitió a sus trabajadores sembrar productos de autoconsumo en sus parcelas privadas, pero no de valor comercial (Koch, 1966, pp. 269, 271; Bourgois, 1994, p. 116; Senior, 2011, pp. 21-22). Por tanto, la temprana década de 1920 vio la última inmigración significativa de afrocaribeños a Costa Rica. En dicho período se dio un traslape significativo en los circuitos de la migración de trabajadores afrocaribeños y mestizos que vinieron a Limón a cultivar bananos y cacao, principalmente. No obstante, a finales de esta década, 
En sintonía con los tiempos: perfil ocupacional y división sexual del trabajo de la población afrocaribeña en Costa Rica durante la primera mitad del siglo XX

las restricciones de inmigración basadas en la "raza" y ejecutadas en los puertos centroamericanos, así como las informales en cuanto al desplazamiento afrocaribeño dentro de Costa Rica, truncaron las migraciones de formas sin precedentes (Putnam, 2002, p. 74; Senior, 2011, p. 34). No obstante, y contra todo tipo de impedimento, para ese entonces ya existía una base laboral afrocaribeña mixta, compuesta por mujeres y hombres sobre los cuales nos interesa profundizar en términos de la división sexual del trabajo establecida a lo largo de la época.

\section{División sexual del trabajo: dinámica de las relaciones afrocaribeñas dentro y fuera del hogar}

La división sexual del trabajo tiene sus orígenes en el ámbito familiar, según lo argumentado por distintos estudios, y logra instituirse mediante el desarrollo cada vez más complejo de las sociedades:

La división del trabajo entre los varones y las mujeres forma parte de la división social del trabajo. Desde un punto de vista histórico, se observa que la actual estructuración de la división sexual del trabajo (trabajo asalariado/trabajo doméstico, fábrica-oficina/familia) apareció simultáneamente con el capitalismo, y que la relación salarial no hubiera podido establecerse en ausencia del trabajo doméstico. Del nacimiento del capitalismo al período actual, las modalidades de esta división del trabajo entre los sexos, tanto en el salariado como en el trabajo doméstico, evolucionan en el tiempo de manera concomitante con las relaciones de producción (Hirata y Kergoat, 1997, como se cita en Kandel, 2006, p. 12).

El concepto sexo-género (patriarcado) lo utilizó Gayle Rubin en 1984 al referirse a un "conjunto de disposiciones por el que una sociedad transforma la sexualidad biológica en productos humanos" (como se cita en Lamas, 2000). Y, como conviene diferenciar estas dos categorías, sexo y género, utilizaremos la categoría "sexo" para determinar las características biológicas, mientras que la categoría "género" como el "conjunto de ideas, prescripciones y valoraciones sociales sobre lo masculino y lo femenino" (Lamas, 2000). Es decir, el (sexo) género es una construcción social (se construye cultural e históricamente), lo cual podrá determinar 
y limitar inclusive, las oportunidades y expectativas de mujeres y hombres en sus respectivas sociedades (Rodríguez, 2016, p. 12). Se parte de considerar que los hombres y las mujeres son seres interdependientes, cuya base material orgánica necesita su interconexión. Concebidos como seres en situación, sus conductas se desarrollan en un tiempo y espacio determinados. Las relaciones de género expresarían, entonces, relacionamientos sociales creados por los seres humanos, y son precisamente esos vínculos los que han instituido roles específicos para uno y otro sexo (Kandel, 2006, p. 15).

En aras de conciliar la vida familiar, laboral y personal, es fundamental saber y entender cómo se organiza el trabajo y de qué manera afecta la vida de las personas, ya que nos encontramos ante un "complejo entramado de vínculos entre la división sexual del trabajo, la organización de la familia y las estrategias de acumulación de capital" (Kandel, 2006, p. 12; Rodríguez, 2016, p. 12). Más que acumulación de capital, nos referiremos concretamente a ingresos a partir de un salario que posibilite unas condiciones mínimas de subsistencia, para el caso de las mujeres y de los hombres afrocaribeños.

Distintas referencias académicas establecen que todas las sociedades se encuentran estructuradas bajo la diferencia sexual. Kergoat (2003) también es partidaria de esta idea y añade que los grupos sexuados no son producto de destinos biológicos, sino que son, ante todo, constructos sociales. La división sexual del trabajo sería universal, pero la forma que adopta se vuelve específica a cada sociedad, y ante la existencia de una gran variabilidad cultural, se demostraría que la vinculación entre trabajo y sistemas de género dependen de factores culturales y no de diferencias biológicas per se entre hombres y mujeres (Comas d'Argemir, 1995, pp. 32-33; Rodríguez, 2016, p. 12).

Dentro de las primeras evidencias, a partir de 1873, la presencia mayoritaria de población jamaiquina respecto de otras provenientes de la cuenca del Caribe posibilitó que sus referentes culturales cimentaran la matriz cultural básica de la población negra en dicha zona costarricense: nutriéndose también con los aportes de las otras tradiciones caribeñas insulares y continentales, así como de las restantes culturas presentes en dicho espacio (Murillo, 1995, p. 78; Senior, 2011, p. 13). Los primeros inmigrantes eran hombres solos que vivían en barracas 
propiedad de la UFCo., pero pronto las familias les siguieron, creando una próspera comunidad afrocaribeña en el área de Limón (Bryce-Laporte, 1993, p. 141). A lo largo de la década de 1920, se estima que muchos trabajaron como arrendatarios o contratistas ya fuera para la UFCo. o bien para los grandes agricultores costarricenses (Chomsky, 1996, p. 34; Senior, 2011, p. 21). La demanda de comestibles en Puerto Limón estimuló la evolución de un centro poblacional secundario estable, aunque algo escaso, de asentamiento afrocaribeño en Cahuita. Por otra parte, en la medida en que los poblados linieros remplazaron las construcciones de campamentos y la población regional creció, el comercio local se expande; y de ahí que, quiénes vendían y dónde lo hacían fue determinado tanto por el origen como por el género. Cada grupo formó comunidades mercantiles muy estrechas en la extensa línea de poblados. Mientras tanto, la compra y venta de provisiones, además de la manufactura y venta de dulces y golosinas, estuvo en manos de mujeres afrocaribeñas. En 1883, la población rural (excepto Puerto Limón) estuvo fuertemente concentrada al oeste del río Pacuare (la Línea Vieja y el distrito del Reventazón), correspondiente a una población trabajadora y con más de 8 hombres por cada mujer (León, 1987, pp. 106, 111; Putnam, 2002, p. 53; Koch, 1966, p. 135; Senior, 2011, pp. 22-23). De ahí que, posteriormente a la etapa pionera, los hombres trajeron a las mujeres de su entorno familiar o personal; además, otras solas comenzaron a emigrar por sus propios medios, aunque usualmente viajaron bajo el patrocinio de parientes o de un futuro esposo. Las condiciones mejoraron lentamente, incluso después de terminada la construcción del ferrocarril. La mayoría del trabajo pesado, de hecho, la mayoría del trabajo, sin contar las actividades portuarias, fue distribuido en las plantaciones, donde se permitió a pocas mujeres acceder a esas áreas y, con excepción de algunas que realizaron tareas domésticas, permanecieron en la relativa seguridad de Puerto Limón (Purcell, 1993, p. 136; Senior, 2011, p. 23).

Una cifra sin precedente de mujeres afrocaribeñas había llegado en el momento de la migración durante la era canalera, y permanecieron para establecer familias en Limón a medida que pasaron los años. El Limón afrocaribeño se había convertido en una sociedad que enviaba personas al exterior, en los mismos años en que la región atrajo migrantes mestizos 
(nacionales y centroamericanos) por millares. Ya sea que fuesen nativos o hubiesen inmigrado durante la niñez, los jóvenes hombres afrocaribeños comenzaron a dejar Limón conforme alcanzaban la edad para emplearse, con rumbo hacia Panamá, la ciudad de Nueva York, Jamaica y, sobre, todo Cuba en aquel momento (Putnam, 2002, p. 36; Senior, 2011, p. 23). Sus pares femeninos permanecieron en la costa: las jóvenes trabajando junto a madres, tías y figuras adoptivas en el puerto y la economía de servicio de los poblados de la Línea, igualmente dedicadas al cuido de las criaturas que formaban parte de la parentela (Putnam, 2002, pp. 5354, 66; Senior, 2011, p. 23).

La niñez conformó una porción en aumento de la población afrocaribeña local; por ello, la adopción informal o "préstamo" de infantes fue tan común en el Caribe en estos años y los posteriores, ya que las madres que tenían fuertes compromisos económicos o muchas bocas que alimentar confiaron sus criaturas a parientes o amistades que contaban con mayores recursos. Putnam (2002), a partir del testimonio judicial, sugiere que este tipo de arreglos fueron bastante comunes en Limón; sin embargo, lo negativo de las familias extendidas o "de crianza" fue que las familias nucleares vivían dispersas y entre la progenie había diferentes apellidos, lo cual no permitía inferir la existencia de consanguinidad. Lo positivo fue la adopción socio-comunitaria que se desarrolló a través de las encargadas de crianza o madres comunitarias. Este tipo de vínculos, y dadas las complejas circunstancias económicas, logró darles una alternativa de sostenibilidad familiar viable (Senior, 2011, pp. 23-24). Además, algunas mujeres que trabajaron como comerciantes, dependientes de negocio, manufactureras o dedicadas a las tareas del hogar, trajeron jovencitas de Jamaica para que las ayudaran en sus labores o para cuidar a los más pequeños. Así, tanto las mujeres como la niñez participaron indirectamente en la economía de exportación, aunque algunas mujeres lo hicieron directamente, siendo la excepción en vez de la regla, ya que no existe evidencia de que fueran prominentes entre quienes colonizaban tierras, o entre pequeños propietarios de terreno; aunado a que ninguna mujer era empleada como trabajadora en las plantaciones bananeras (Putnam, 2002, pp. 54-55; Senior, 2011, p. 24).

Hasta aquí es evidente que la familia, en tanto entidad, en su vínculo con el trabajo, entendido como el conjunto de los ámbitos profesional 
y doméstico, fueron necesarios para la supervivencia de la unidad, y es en dicha unidad en la que el trabajo se reparte, confirmando la indisoluble relación del binomio trabajo-familia (Kandel, 2006, 14). Para Barrère-Maurisson (2000), se trataría entonces de "concebir a la familia, con relación al trabajo, no como lugar de lo privado o de lo biológico, sino como un lugar donde se expresan varios vínculos sociales, en particular entre los sexos y con respecto al trabajo. Este es el principio de la división sexual del trabajo" (como se cita en Kandel, 2006, pp. 13-14).

En nuestras sociedades, la lógica de los vínculos sociales de sexo les atribuye un lugar secundario a las mujeres, lo que plantea un fenómeno de "inferiorización" en el empleo - pese a una inserción masiva-. Este fenómeno genera, a su vez, una posición generalmente subordinada dentro de la familia en términos de estatus social, de vínculo con el poder, de reparto de las tareas, etc. En síntesis, para Kandel (2006), la división sexual del trabajo es constitutiva de la división social, y el trabajo en la esfera pública está interconectado con la esfera privada, especialmente con la reproducción de la vida y de la organización familiar (Kandel, 2006, pp. 14-15). A esta altura, basta recordar el contexto histórico-social del momento. Las mujeres compartían o detentaban la jefatura del hogar, ya fuese por voluntad o por contingencia, y dentro de esta, su máxima aspiración fue el bienestar familiar, que en el caso de muchas afrocaribeñas se fue traduciendo paulatinamente en lograr un arraigo que, a su vez, proporcionara estabilidad para el desenvolvimiento personal de sus parientes y allegados. Un sector de los hombres afrocaribeños que radicaron en el país, así como gran parte de quienes recurrieron a las migraciones temporales, se fueron convenciendo con el pasar del tiempo sobre la importancia que tenía el establecerse, especialmente tomando en cuenta los derechos adquiridos que la gran mayoría tenía por haber nacido en Costa Rica (Senior, 2011, pp. 86-87). Por ello, en el marco de una época que sentó las bases no solo de las funciones, sino también de los relacionamientos en el interior del engranaje familiar, social y laboral, se torna fundamental particularizar sobre la distribución de los oficios ejercidos por las mujeres, así como por los hombres afrocaribeños en esta primera mitad del siglo XX. 
Diana Senior Angulo

\section{Perfil ocupacional de mujeres y hombres afrocaribeños en sintonía con los tiempos de la primera mitad del siglo XX}

La división sexual del trabajo se entiende como el "reparto social de tareas o actividades según sexo-género” (Gómez Bueno, 2001, p. 124), y aunque dicho reparto no ocurre de la misma manera en diferentes partes del mundo, el concepto sirve como base común para todas las sociedades (Rodríguez, 2016, p. 12), si lo que se pretende es entender la dinámica particular de cada una. Por tanto, pese al impacto de la economía bananera en la economía nacional costarricense, la producción de la fruta no causó una migración sustantiva desde el interior del país hacia Limón, salvo en el período inicial de 1883 a 1892. Los censos demuestran que, de 1892 a 1927, la población costarricense de Limón había aumentado solamente en $1 \%$ por año, de 6.928 a 9.970 personas; mientras que la población afrocaribeña aumentó 10.5\% anual, de 541 a 18.003 personas. De todas maneras, la migración de Jamaica a Costa Rica cae abruptamente después de 1913 (Casey, 1979, pp. 237-238; Senior, 2011, p. 33).

El resultado agregado de estos recorridos en el sistema migratorio del Caribe devino en que, incluso cuando aumentó el número de mestizos desempleados, los afrocaribeños dominaron las filas del personal de servicio de rango medio, así como de los pequeños propietarios rurales. Dos factores distintos, de acuerdo con Putnam (2002), condujeron a esta movilidad ascendente en los años posteriores a la Primera Guerra Mundial (1914-1918). El primero fue el éxodo de los hombres afrocaribeños jóvenes menos acomodados, ya que los datos censales sugieren un casi absoluto rechazo al trabajo de la plantación por parte de este grupo en favor de la emigración. En 1927, solamente $28 \%$ de los hombres en edades entre 15 y 29 años eran empleados agrícolas, comparados con $80 \%$ de sus pares mestizos. El segundo factor fue la adultez dentro de la región por parte de los hombres afrocaribeños mayores de 45 años (Putnam, 2002, pp. 69-70; Senior, 2011, p. 35).

En cuanto al censo de 1950, en el cuadro 1 se observa que la cantidad de población afrocaribeña a nivel nacional y provincial siguió en franco descenso, como resultado de los procesos de exclusión social y abandono económico experimentado en la provincia; lo cual logra empujar a un 
En sintonía con los tiempos: perfil ocupacional y división sexual del trabajo de la población afrocaribeña en Costa Rica durante la primera mitad del siglo XX

remanente de población masculina a abandonar el país en busca de mejores oportunidades; fenómeno que años más tarde sería emulado mayoritariamente por las mujeres afrocaribeñas.

Cuadro 1. Censos de 1927 y 1950, su población total y su distribución entre: Mujeres, Hombres y Negros a nivel nacional, y en los niveles provinciales de San José y Limón

\begin{tabular}{|c|c|c|c|c|}
\hline Costa Rica & $\begin{array}{c}\text { Total de la } \\
\text { población }\end{array}$ & $\begin{array}{c}\text { Total de } \\
\text { mujeres }\end{array}$ & $\begin{array}{c}\text { Total de } \\
\text { hombres }\end{array}$ & Negros \\
\hline Nivel nacional, Censo 1927 & 471.524 & 233.496 & 238.028 & 19.136 \\
\hline $\begin{array}{c}\text { Nivel nacional, Censo 1950 } \\
\text { Nivel Provincial (San José), } \\
\text { Censo 1927 }\end{array}$ & 153.183 & 78.736 & 74.447 & 431 \\
\hline $\begin{array}{c}\text { Nivel Provincial (San José), } \\
\text { Censo 1950 }\end{array}$ & 281.822 & 146.759 & 135.063 & 694 \\
\hline $\begin{array}{c}\text { Nivel Provincial (Limón), } \\
\text { Censo 1927 }\end{array}$ & 32.278 & 14.622 & $17.656^{* *}$ & 18.003 \\
\hline $\begin{array}{c}\text { Nivel Provincial (Limón), } \\
\text { Censo 1950 }\end{array}$ & 41.360 & 19.432 & 21.928 & 13.749 \\
\hline
\end{tabular}

${ }^{*}$ Estimación hecha por el matemático G.R. Pizarro, a partir del censo de 1927, el cual establece que había $2.8 \%$ más hembras que varones (p. 62).

** Estimación hecha por el matemático G.R. Pizarro, a partir del censo de 1927, el cual establece que había $9.4 \%$ más varones que hembras (p. 62).

Fuente: Censo de Población de Costa Rica (1960), pp. 23, 32, 36, 38, 63, 90, 93; Censo de Población de Costa Rica (1975), pp. 7, 34, 105-106, 108, 115. 
Sin embargo, dejando de lado el malestar social de la década de 1920, y sin importar el patrón específico que se siga, hay que reconocer que el resultado final de las políticas de la UFCo. fue la conformación de una jerarquía de "estratificación racial-ocupacional". No olvidemos que el éxito tenido por la UFCo. en deshacerse de todos sus competidores había eliminado la posibilidad del establecimiento de canales alternativos para comercializar ya fuese banano o cacao. De ahí que varios investigadores hayan descrito a los agricultores de la primera década del siglo XX como trabajadores asalariados privilegiados, quienes tenían toda la apariencia de ser independientes, pero en la práctica eran proletarios disfrazados de campesinos. Este arreglo probó ser útil para la gerencia, ya que los salarios de la plantación podían ser rebajados por cuanto una gran parte de la fuerza de trabajo complementaba sus entradas con la producción campesina, tanto de subsistencia como de productos para el mercado. De hecho, muchos trabajadores bananeros de comienzos del siglo XX se vieron obligados a ser, a la vez, campesinos de medio tiempo para poder sobrevivir (Bourgois, 1994, pp. 112, 114; Senior, 2011, pp. 37-38).

La división social y técnica del trabajo como parte de la división sexual que surge de su organización puede ser impuesta, asignada o negociada con quienes van a ejecutar las tareas. Asimismo, los requerimientos del puesto de trabajo pueden o no estar de acuerdo con las calificaciones profesionales de las personas trabajadoras, sus intereses, sus deseos o sus aspiraciones (Kandel, 2006, p. 22). La división técnica del trabajo se referiría a la mayor o menor parcelación de las tareas, asignándole a cada persona trabajadora en su propio puesto de trabajo la realización de un ciclo operatorio que debe cumplirse en un tiempo dado. Según cómo sea el proceso de trabajo predominante, su división técnica será más o menos intensiva (Neffa, 1989, como se cita en Kandel, 2006, p. 22). En el cuadro 2, el censo de 1927 nos da un panorama de la distribución numérica de mujeres y hombres. La población económicamente activa de la república ascendía a 152.263 personas, de las cuales 16.784 fueron mujeres mientras que 135.479 eran hombres (p. 54). A nivel nacional, se establece que la mayor ocupación del país correspondía a la agricultura, con 95.387 personas; actividad para la cual se dedicaron solo 584 mujeres, frente a 94.803 hombres (p. 54). 
En sintonía con los tiempos: perfil ocupacional y división sexual del trabajo de la población afrocaribeña en Costa Rica durante la primera mitad del siglo XX

Cuadro 2. Censo de 1927 y población económicamente activa y su distribución por: sector ocupacional, total de la población, mujeres y hombres a nivel nacional.

\begin{tabular}{|l|c|c|c|}
\hline \multicolumn{1}{|c|}{ Sector ocupacional } & $\begin{array}{c}\text { Total de la población } \\
\text { económicamente activa }\end{array}$ & Mujeres & Hombres \\
\hline Agricultura & 95.387 & 584 & 94.803 \\
\hline Industria & 18.834 & 3.486 & 15.348 \\
\hline Servicios & 10.541 & 6.896 & 3.645 \\
\hline Administración pública & 8.308 & 2.741 & 5.567 \\
\hline Comercio & 5.403 & 361 & 5.042 \\
\hline Otras ocupaciones & 5.195 & 1.560 & 3.635 \\
\hline Profesiones liberales & 3.107 & 386 & 2.721 \\
\hline Minería & 398 & 398 & - \\
\hline
\end{tabular}

Fuente: Censo de población de Costa Rica (1960), pp. 54-57.

Como muestra el cuadro 2, en el censo de 1927, a la agricultura le siguieron en orden de importancia los siguientes oficios:

- Industria: 18.834 personas en total; 3.486 mujeres y 15.348 hombres.

- Servicios: 10.541 personas en total; 6.896 mujeres y 3.645 hombres.

- Administración pública: 8.308 personas en total; 2.741 mujeres y 5.567 hombres.

- Comercio: 5.403 personas en total; 361 mujeres y 5.042 hombres.

- Otras ocupaciones: 5.195 personas en total; 1.560 mujeres y 3.635 hombres.

- Comunicaciones y transporte: 3.643 personas en total; 114 mujeres y 3.529 hombres.

- Profesiones liberales: 3.107 personas en total; 386 mujeres y 2.721 hombres.

- Minería: 398 personas en total; todos hombres.

Cabe destacar la no existencia de datos desagregados mediante el cruce de sexo y "raza". Sin embargo, y en concordancia con la época, del total de 
19.136 negros en el país, tenemos a 18.003 ubicados en la provincia de Limón; por lo que, siguiendo la tendencia nacional, se puede argumentar que la mayoría de tales correspondía a hombres agricultores, pese al descenso en la permanencia laboral o elección de dicha ocupación en el momento del conteo poblacional — finales de la década de 1920—; mientras que las mujeres se desempeñaron mayoritariamente en el sector de los servicios.

En el cuadro 3, el censo de 1950 también nos da un panorama de la distribución numérica de mujeres y hombres. La población económicamente activa de la república ascendía a 271.984 personas, de las cuales 41.835 fueron mujeres, mientras que 230.149 eran hombres (p. 284). A nivel nacional, se establece que la mayor ocupación del país correspondía a la "agricultura, silvicultura, caza y pesca" con 148.837 personas; actividades para las cuales se dedicaron: solo 4.710 mujeres, frente a 144.127 hombres (p. 292).

Cuadro 3. Censo de 1950 y población económicamente activa y su distribución por: sector ocupacional, total de la población, mujeres, hombres y a nivel nacional.

\begin{tabular}{|l|c|c|c|}
\hline \multicolumn{1}{|c|}{ Sector ocupacional } & $\begin{array}{c}\text { Total de la población } \\
\text { económicamente activa }\end{array}$ & Mujeres & Hombres \\
\hline $\begin{array}{l}\text { Agricultura, silvicultura, } \\
\text { caza y pesca }\end{array}$ & 148.837 & 4.710 & 144.127 \\
\hline Servicios & 40.166 & 25.657 & 14.509 \\
\hline $\begin{array}{l}\text { Industrias } \\
\text { manufactureras }\end{array}$ & 29.870 & 6.547 & 23.323 \\
\hline Comercio & 21.412 & 4.073 & 17.339 \\
\hline Construcción & 11.625 & 57 & 11.568 \\
\hline $\begin{array}{l}\text { Transporte, almacenaje } \\
\text { y comunicaciones }\end{array}$ & 9.465 & 504 & 8.961 \\
\hline $\begin{array}{l}\text { Actividades no bien } \\
\text { especificadas }\end{array}$ & 8.248 & 244 & 8.004 \\
\hline $\begin{array}{l}\text { Electricidad, agua } \\
\text { y servicios sanitarios }\end{array}$ & 1.607 & 36 & 1571 \\
\hline $\begin{array}{l}\text { Explotación de minas } \\
\text { y canteras }\end{array}$ & 754 & 7 & 747 \\
\hline
\end{tabular}

Fuente: Censo de población de Costa Rica (1975), pp. 292-295. 
En sintonía con los tiempos: perfil ocupacional y división sexual del trabajo de la población afrocaribeña en Costa Rica durante la primera mitad del siglo XX

Como lo muestra el Cuadro 3, luego de la agricultura, en el censo de 1950 le siguieron en orden de importancia los siguientes oficios:

- Servicios: 40.166 personas en total; 25.657 mujeres y 14.509 hombres.

- Industrias manufactureras: 29.870 personas en total; 6.547 mujeres y 23.323 hombres.

- Comercio: 21.412 personas en total; 4.073 mujeres y 17.339 hombres.

- Construcción: 11.625 personas en total; 57 mujeres y 11.568 hombres.

- Transportes, almacenaje y comunicaciones: 9.465 personas en total; 504 mujeres y 8.961 hombres.

- Actividades no bien especificadas: 8.248 personas en total; $244 \mathrm{mu}$ jeres y 8.004 hombres.

- Electricidad, agua y servicios sanitarios: 1.607 personas en total; 36 mujeres y 1.571 hombres.

- Explotación de minas y canteras: 754 personas en total; 7 mujeres y 747 hombres.

Al igual que para el censo de 1927, cabe destacar que en el censo de 1950 tampoco se recopilaron datos mediante el cruce de variables de sexo y "raza". Sin embargo, y en concordancia con la época, del total de 15.118 negros en el país, tenemos a 13.749 ubicados en la provincia de Limón, por lo que, siguiendo la tendencia nacional, se puede argumentar que la mayoría de tales seguía correspondiendo a hombres agricultores, pese al descenso en la permanencia laboral y/o elección de dicha ocupación hacia finales de la década de 1940. En el caso de las mujeres, siguieron desempeñándose mayoritariamente y en franco ascenso en el sector de los servicios.

Para complementar mejor el panorama sintetizado en los últimos dos cuadros relativos a oficios y desagregados entre mujeres y hombres, contamos con la "Base de datos de la Población Afrocaribeña Naturalizada entre 1927 y 1963", la cual registró la ocupación u oficio de 731 personas (Senior, 2011, pp. 174, 196-197). De esta fuente y dentro de la división técnica del trabajo, se evidenciaron dos actividades económicas dominantes entre quienes se naturalizaron durante el período descrito: por un 
lado, los oficios domésticos, 201 mujeres, y, por el otro, los agricultores, con 91 hombres. Dentro de estos, se incluiría la categoría de jornaleros, incorporada por el censo de 1927 por lo que aumentaría a 14 personas (presumiblemente todos hombres). Entre ambos oficios (lo doméstico y la agricultura) es evidente la estricta división sexual del trabajo, aunque la mayoría de quienes se naturalizaron fueron hombres, con una mayor especialización y diversificación en los oficios, a diferencia de las mujeres (Senior, 2011, p. 194). Por último, la fuente no da indicio de hombres afrocaribeños ligados a la minería, lo cual coincide con las informaciones recopiladas en ambos censos.

Como dato adicional y a diferencia del censo de 1950, el censo de 1927 desglosa la siguiente lista de oficios, los cuales se encuentran en la "Base de Datos de la Población Afrocaribeña Naturalizada entre 1927 y 1963”:

- En cuanto al sector de la "Industria", se contabilizaron los siguientes oficios: 17 carpinteros, 14 mecánicos, 8 sastres, 6 costureras, 6 panaderos, 3 electricistas, 3 pintores, 3 zapateros, un albañil, un ebanista, un fontanero, un pescador y una modista. En cuanto a oficios no indicados por el censo, tenemos: seis artesanos, un barbero, un foreman (capataz) y un plomero.

- Dentro de las "Comunicaciones y transporte" se contabilizaron, entre los oficios, a: 6 choferes, 4 fogoneros, 3 ferrocarrileros, 2 marinos, 2 telefonistas, un brequero, un maquinista, un telegrafista y un tractorista.

- En el sector "Comercio" se encontraron: 22 comerciantes en general; y en cuanto a oficios no indicados por el censo, a 9 empleados de comercio.

- Con relación a la "Administración pública" se contabilizó a un empleado público y a un profesor.

- En las "Profesiones liberales" se encontraron los siguientes oficios: cinco contabilistas (contador), dos escribientes, dos boticarios, un artista, un farmacéutico, un ingeniero, un músico, un tenedor de libros y una obstetra; mientras que en "Oficios no indicados por el Censo": un boxeador, un tipógrafo y una manicurista.

- En el sector "Servicios" se contabilizaron ocho enfermeras y dos cocineras (cocina). 
- Y dentro de "Otras ocupaciones" se encontraron: 16 oficinistas no especificados; mientras que en "Oficios no indicados por el censo": un empleado, un estudiante, un misceláneo y un obrero.

En síntesis, como hemos visto, el detalle de los oficios derriba el mito de la inexistencia de afrocaribeños desempeñándose en otro tipo de actividades ajenas al agro o a los servicios, como fue el caso de las "profesiones liberales" u otras, rebautizadas a posteriori o inclusive no consideradas por mujeres y hombres afrocaribeños, como tampoco por ulteriores conteos poblacionales.

Por otra parte, dentro de la división social imperante en la época la división sexual y técnica de los oficios desempeñados en su mayoría confirma la estructuración del género - con sus excepciones-, dentro de las labores realizadas tanto por mujeres como por hombres afrocaribeños, en sintonía con la segmentación sexual y laboral de las poblaciones económicamente activas en las sociedades de aquel entonces.

\section{Conclusiones}

Los contingentes poblacionales afrocaribeños que migraron a finales del siglo XIX y que continuaron haciéndolo durante diferentes momentos de la primera mitad del siglo XX lograron equipararse, pasando de ser abrumadoramente masculinos a incorporar a mujeres, quienes terminaron por reconfigurar las relaciones económicas que se establecieron en la nueva provincia de Limón.

La diversidad de personas trabajadoras en términos de sexo (género) propició la dinamización económica gracias al incremento de la demanda de bienes y servicios aparejada al crecimiento demográfico generalizado en la provincia de Limón. Lo anterior se produjo durante las primeras décadas correspondientes a los arribos afrocaribeños. Aunque ello generara una economía local, esta logró sostenerse en medio de momentos de fragilidad, por ejemplo, ante el abandono estructural de la provincia de Limón y frente a la disminución numérica afrocaribeña hacia mediados de la primera mitad del siglo XX.

La reproducción social desempeñó un rol fundamental y aunado a los roles sociales tradicionales de la época, pese al reparto relativo de 
las actividades y tareas asumidas tanto por mujeres como por hombres afrocaribeños dentro del hogar. Dentro de este espacio, el peso lo terminaron asumiéndo las mujeres afrocaribeñas. Sus principales labores estuvieron dedicadas al ámbito privado y circunscritas a lo familiar, las cuales comenzaron a incursionar y combinar de manera creciente con actividades económicas en el sector de los servicios.

Eric Hobsbawm (1998) al analizar el rol de las mujeres en general durante el siglo XX (1945-1990) señala que la entrada de las mujeres al mercado laboral no era ninguna novedad, y que a partir de finales del siglo XIX, el trabajo de oficina, en las tiendas y en determinados tipos de servicio, como las relativas al cuidado de personas, experimentaron una fuerte feminización. Ello provocó que estas ocupaciones terciarias se expandieran y crecieran a expensas (en cifras relativas y absolutas) tanto de las actividades primarias como de las actividades secundarias, es decir, de la agricultura y la industria, respectivamente (Kandel, 2006, p. 37).

Como pudimos observar y a partir de las fuentes disponibles, durante un largo período de tiempo el trabajo en la esfera pública fue considerado exclusivamente "cosa de hombres", mientras que el trabajo doméstico quedó bajo la responsabilidad de las mujeres. En ese sentido, y para el caso de las mujeres afrocaribeñas, el trabajo que tuvieron disponible a la mano para ser realizado también evidenció precisamente el lugar que estaban destinadas a ocupar en materia económico-productiva y laboral que, con sus excepciones, termina siendo un fiel reflejo de la realidad social de la época.

Por último, hay que señalar que las trayectorias individuales pesaron colectivamente en las decisiones en cuanto a los oficios escogidos. Por ello, aunque pueda notarse una línea en cuanto a la división sexual del trabajo (Senior, 2011, p. 195), un segmento poblacional correspondiente a técnicos y profesionales, ya fuesen inmigrantes o formados en suelo nacional, lograron contribuir a través de generaciones posteriores, al desarrollo de la industria y economía en la región Caribe de Costa Rica.

\section{Referencias}

Barrere-Maurisson, M. A. (2000). La división familiar del trabajo. La vida doble y desempleo. Buenos Aires: Asociación Trabajo y Sociedad, Programa de Investigaciones Económicas sobre Tecnología, Trabajo y Empleo, CEIL-PIETTE-CONICET. 
En sintonía con los tiempos: perfil ocupacional y división sexual del trabajo de la población afrocaribeña en Costa Rica durante la primera mitad del siglo XX

Bourgois, P. (1994). Banano, etnia y lucha social en Centroamérica. San José DEI. Brunet Icart, I. y Santamaría Velasco, C. A. (2016). La economía feminista y la división sexual del trabajo. Culturales, época II, 4(1), 61-86.

Bryce-Laporte, R. S. (1993). A Lesser Known Chapter of the Diaspora: West Indians in Costa Rica, Central America. En J. Harris (ed.), Dimensions of the African Diaspora (pp. 137-157). Washington: Howard University Press.

Casey Gaspar, J. (1979). Limón 1880-1940: un estudio de la industria bananera en Costa Rica. San José ECR.

Censo de Población de Costa Rica (1960).11 de mayo de 1927, San José DGEC.

Censo de Población de Costa Rica (1975). 22 de mayo de 1950, San José DGEC.

Comas d'Argemir, D. (1995). Trabajo, Género y Cultura. La construcción de desigualdades entre hombres y mujeres. Barcelona: Icaria.

Chomsky, A. (1996). West Indian Workers and the United Fruit Company in Costa Rica, 1870-1940. Banton Rouge: Louisiana State University Press.

Gómez Bueno, C. (2001). Mujeres y trabajo: principales ejes de análisis. Papers 63(64), $123-140$.

Hirata, H. y Kergoat, D. (1997). La división sexual del trabajo. Permanencia y cambio. Buenos Aires: Asociación Trabajo y Sociedad, Centro de Estudios de la Mujer y PIETTE del CONICET.

Hobsbawn, E. J. (1998). Historia del Siglo XX. Barcelona: Ediciones Crítica.

Kandel, E. (2016). División sexual del trabajo ayer y hoy: una aproximación al tema. Buenos Aires: Editorial Dunken.

Kergoat, D. (2003). De la relación social del sexo al sujeto sexuado. Revista Mexicana de Sociología, (4), 841-861.

Koch, C. (1966). Ethnicity and Livelihoods, a social geography of Costa Rica's Atlantic Zone (tesis de doctorado no publicada). Universidad de Kansas, Kansas, Estados Unidos.

Lamas, M. (2000). Diferencias de sexo, género y diferencia sexual. Cuicuilco Nueva Época, 7(18), 1-24.

León Azofeifa, M. G. (1987). Chinese Immigrants on the Atlantic Coast of Costa Rica: The Economic Adaptation of an Asian Minority in a Pluralistic Society (tesis de doctorado, Universidad de Tulane, Nueva Orleans, Estados Unidos). Recuperado de https://digitallibrary.tulane.edu/islandora/object/ tulane\%3A23122.

Marquardt, S. (2001). 'Green Havoc': Panama Disease, Environmental Change and Labor Process in the Central American Banana Industry. American Historical Review, 106(1), 49-80. 
Diana Senior Angulo

Murillo, C. (1995). Identidades de hierro y humo. La construcción del Ferrocarril al Atlántico 1870-1890. San José: Editorial Porvenir.

Neffa, J. C. (1989). ¿Qué son las condiciones y medio ambiente del trabajo? Propuesta de una nueva perspectiva. Buenos Aires: Área de Estudio e Investigación en Ciencias Sociales del Trabajo, Centro de Estudios e Investigaciones Laborales, CREDAL - CNRS / Humanitas.

Purcell, T. (1993). Banana Fallout: Class, Color and Culture among the West Indians in Costa Rica. Los Angeles: University of California.

Putnam, L. (2002). The Company they Kept. Migrants and the Politics of Gender in Caribbean Costa Rica 1870-1960. Carolina del Norte: University of North Carolina Press.

Quesada Camacho, J. R. (1977). Algunos aspectos de la historia económica del cacao en Costa Rica: 1880-1930. Revista de Historia (UNA), 3(5), 65-100.

Rodríguez Moro, C. (2016). La persistencia de la división sexual del trabajo en la conciliación de la vida familiar, personal y laboral (tesis de pregrado, Universidad de Valladolid, Soria, España). Recuperado de https://uvadoc.uva.es/bitstream/handle/10324/23395/TFG-O\%20955. pdf? sequence $=1$ \&isAllowed $=\mathrm{y}$.

Rubin, G. (1984). Thinking Sex: Notes for a Radical Theory of the Politics of Sexuality. En C. S. Vance (ed.), Pleasure and Danger: Exploring Female Sexuality (pp. 267-319). Boston: Routledge \& Kegan Paul..

Solimano, A. (2003). Globalización y Migración Internacional: la experiencia latinoamericana. Revista de la CEPAL, (80), 55-72. 



\section{El Caribe hondureño y su negritud: ¿una amenaza para los obreros o un peligro para la nación?}

Yesenia Martínez García

Universidad Nacional Autónoma de Honduras

\section{Introducción}

Abordar el estudio sobre la presencia de la población antillana o negra de habla inglesa en Honduras surge luego de un proceso de investigación sobre "Salud Nacional y Salud Transnacional en la atención de enfermedades infecciosas y tropicales de las poblaciones subalternas en Tegucigalpa y el Caribe de Honduras, 1902-1933". Se da en el contexto de la segunda etapa de la Reforma Liberal (1876-1949). Para este estudio, estos sujetos de la historia se incluyen como parte de la población subalterna, trabajadora y enferma en los espacios del Caribe hondureño (en los departamentos de Atlántida, Cortés, Colón y Yoro). Cabe mencionar que en esta categoría de subalternos se encuentra población indígena, mestiza, negros "garífunas" de origen hondureño y de otros países centroamericanos, así como negros procedentes de Haití, Jamaica, Trinidad y Tobago, el Gran Caimán y Belice. Es toda una población migrante, culturalmente heterogénea, con particularidades tanto discursivas como de sus prácticas culturales. Ello fue motivo de rechazo de parte de varios sectores de la población hondureña a población de origen negro de habla inglesa que llegó a Honduras en los primeros años del siglo XX. 
Estas poblaciones de origen antillano se establecieron en la región del Caribe hondureño; el mismo espacio que se caracterizó por las relaciones de dominio colonialista y transnacional más importante en Honduras en la primera mitad del siglo XX. En el contexto de la economía de plantación del banano, se analizarán los vínculos entre las relaciones del capitalismo y el trabajo. Allí también se presenció resistencias, no solo entre poblaciones subalternas contra los inversionistas, sino también entre los mismos subalternos. O, más aún, se dieron conflictos entre el Estado y otros sectores: intelectuales, comerciantes y la prensa, por la presencia de trabajadores antillanos, negros de habla inglesa, a quienes se les caracterizaba como una amenaza para las oportunidades laborales en las actividades agroindustriales, particularmente del banano y del ferrocarril. A ellos los veían "como el problema negro", en parte por sus experiencias laborales en las plantaciones de banano, por sus prácticas culturales, su idioma y, hasta cierto punto, por sus padecimientos de enfermedades contagiosas. Esto, según la élite política, los intelectuales y las mismas organizaciones obreras, no contribuía a la "raza" o a la imagen de la nación moderna. Fueron expresiones y manifestaciones que se hicieron sentir en otras regiones de Honduras, pero de manera más agresiva en la región del Caribe.

Por lo anterior vale preguntarse: ¿cuáles fueron los discursos, mecanismos legales o manifestaciones de rechazo de parte del Estado, intelectuales, obreros y la prensa hondureña ante la presencia de la población antillana o negra de habla inglesa contratada para las actividades agroindustriales en Honduras, en el marco de la construcción de la imagen de la nación moderna y homogénea durante las primeras tres décadas del siglo XX? Para responder a esta interrogante y tratándose de poblaciones subalternas, en este caso, de los negros de habla inglesa como sujetos históricos en espacios de relaciones de dominio en el contexto histórico de la formación del Estado nación, se consideran los aportes teóricos y metodológicos que ofrece la historia sociocultural, desde la perspectiva de los estudios subalternos y los estudios culturales. En ese sentido, son acertados los planteamientos de Stuart Hall en su obra The Fateful Triangle. Race, Ethnicity and Nation (2017) y de Mahomood Mamdani en Define and Rule: Native as Political Identity (2012). Estos planteamientos se complementan con aportes de la historiografía hondureña y se 
aplican al análisis e interpretación de las fuentes primarias con carácter legal y oficial sobre el registro de la población, la inmigración, concesiones y contratos. Se complementa, además, con un fuerte aporte de fuentes hemerográficas.

\section{Concesiones, discursos, legislación y manifestaciones de rechazo por la presencia de trabajadores antillanos o negros de habla inglesa}

Los aportes de Hall (2017) permiten comprender la conceptualización de los términos "raza" y "etnicidad" y la presencia del sujeto negro con una mirada en las diferencias sociohistóricas, no desde conceptos biológicos que promueve el o los procesos de la formación de los Estados nacionales. Esto consiste, según Hall, en el análisis discursivo de las diásporas, de sus prácticas y experiencias articuladas, tales como: los idiomas compartidos, las tradiciones, las creencias religiosas, las ideas culturales, costumbres y rituales que unen a grupos particulares (p. 83). Sus interpretaciones se prestan para analizar los estudios sobre la diáspora afrodescendiente iniciados en el siglo XVII, y el rol de los Estados colonialistas europeos y las relaciones hegemónicas implementadas por el capitalismo estadounidense en las regiones del Caribe a inicios del siglo XX. Para este autor, su preocupación va más allá de la inclusión del concepto de raza y etnia como productos de las diásporas, es también sus experiencias y las diferencias en sus prácticas culturales desde un colectivo, resaltando la relación entre "naciones y diásporas" o "diáspora y nación" para el estudio de las identidades (pp. 26, 162-163).

Esta es una manera particular de ver la identidad cultural vinculada con las diásporas, lo cual, según Hall, establece las diferencias, representado en el sujeto histórico "negro", y viendo el "caribeñismo" de la experiencia negra como la identidad de la diáspora. De ahí parte la relación entre identidad étnica e identidad cultural en momentos de relaciones imperialistas y hegemónicas en Centro y América Latina, Europa y Asia (pp. 4-8). Esta referencia se relaciona, aunque desde una perspectiva legal y en un contexto temporal más estrecho entre mediados del siglo XIX y mitad del siglo XX, con los planteamientos de Mamdani (2012). Para Hall (2017), se debe interpretar el conjunto de normativas legales que producen los sistemas coloniales que lleva a la construcción ideológica 
y la instrumentalización de ver dos tipos de poblaciones: la aborigen y el civilizado, o el nativo y los colonos, en contextos de construcción del Estado moderno. Es ver, desde los aportes de Mamdani (2012), ese proceso de forzar un discurso legal que configura las identidades, en un momento en que los negros de habla inglesa son sujetos de resistencia en un escenario de colonización sobre la segregación indígena y negra, no respetando sus leyes consuetudinarias que marcan sus diferencias y prácticas culturales (pp. 14-20). Y que también se consideran población subalterna, y muchas veces como agentes de contagio, contratados como mano de obra en las actividades agroindustriales, economía que le dio el carácter de un Estado liberal con la visión de la nación moderna.

Desde estos planteamientos se analiza lo sucedido en las primeras tres décadas del siglo XX en Honduras. En ese período se promueven las ideas liberales con intenciones de llevar la economía a un mercado transnacional, un proyecto iniciado desde el gobierno de Marco Aurelio Soto (1876-1883), precursor de la Reforma Liberal en Honduras. También es el tiempo en que se construyó un marco jurídico y un discurso racial y de estigmatización ante la presencia de los trabajadores antillanos como mano de obra en las actividades agroindustriales, ya sea en fábricas, en las plantaciones de banano o en construcciones del ferrocarril. A ello se suma un discurso sobre el contagio y la inmunidad.

A estos individuos se les denominó "operarios de la raza negra" y "trabajadores extranjeros". Por su condición y experiencia en las labores de plantaciones, se les identificó como parte de la "élite subalterna", tanto por su idioma, utilizado para el acercamiento con los dominantes o los funcionarios de las compañías bananeras, como también por su experiencia de trabajo en actividades de plantaciones en otras áreas de Centroamérica y el Gran Caribe, particularmente los jamaiquinos en la Boston Fruit Company, antecesora de la United Fruit Company (UFCo) (Chambers, 2010, pp.14-15).

En la región centroamericana, a los antillanos se les facilitó contratos para trabajar en los muelles, como capataces, capitanes, chequeadores, oficinistas, vigilantes y puestos de supervisión, o en los puestos del ferrocarril, como maquinistas, fogoneros y brequeros (Acuña, 1993, pp. 255-323). Los registros de esta población en el Caribe hondureño son variados, cercanos a los puertos y zonas de cultivo del banano y la 
construcción del ferrocarril. Uno de los más importantes fue en la ciudad de La Ceiba, sede de la UFCo y la Vaccaro Brother Company desde 1899. Ahí, la población de habla inglesa fue contratada para oficios variados como contadores, carpinteros, conductores, panaderos, obreros, cocineros, meseros y jefes de campos. ${ }^{73}$

El poseer experiencia en plantaciones en otras regiones del Caribe, el hablar el idioma inglés y el tener prácticas culturales distintas provocó diferencias y resistencias con la población oriunda, obreros, Gobiernos e intelectuales. Ello explica la reacción del alcalde municipal de La Ceiba en 1924, don Rafael Canelas, quien denegó la solicitud presentada por vecinos del Barrio Inglés, donde había una elevada concentración de trabajadores negros antillanos, para que se asignara un profesor de inglés en la escuela privada de este barrio. Según la solicitud, era de suma utilidad el aprendizaje de ese idioma, pero el alcalde Canelas negó tal petición por ser de carácter privado, sostenida por particulares y no conforme con el reglamento de instrucción primaria. ${ }^{74}$

Este suceso está conectado a lo que expone el lingüista Atanasio Herranz (1998) sobre la historia del gran Caribe y la segregación, discriminación, miseria y la destrucción de identidades nativas, por la construcción de sociedades híbridas con un idioma, el español. Para este autor, fue en los inicios del siglo XX cuando se manifestaron no solo las diferencias en poblaciones de negros garífunas y negros de habla inglesa, en el contexto de las diásporas y la configuración de un nuevo espacio sociocultural, sino también como producto de la hegemonía del banano, que despojó y provocó no solo el desplazamiento y reducción de sus patrias a las poblaciones del Caribe de Honduras. Para Herranz, la discriminación racial también se dio por el idioma, refiriéndose a que ya no solo era el español, sino también la llegada del idioma inglés como símbolo de poder en la región. Esto afectó sus prácticas y herencias de poblaciones nativas "particularmente para los jicaques, payas, garífunas y hablantes del inglés creole" (p. 170). Pero el idioma se caracterizó sobre todo por ser también

73. Ver Holy Trinity Church, in the Republic of Honduras, La Ceiba (HTCLC), Registry Baptisms 1915-1956, pp.1-25; también en Soluri (2013, p. 242).

74. Archivo Municipal de La Ceiba (AMLC), Libro de actas no. 19, del 8 de septiembre de 1923 al 1 de marzo de 1929, folios 56-57, Sesión Municipal del 15 de febrero de 1924. 
un problema de oportunidades laborales para los obreros hondureños. Situación que ha expuesto la historiografía sobre estas poblaciones (Euraque, 2008; Acuña, 1993; Amaya, 2017; Payne, 2001).

Las manifestaciones se hicieron sentir hacia los antillanos contratados tanto por los inversionistas de la Vaccaro Brother Company, luego fusionada a Standard Fruit Company, como por las subsidiarias de la UFCo. y otros inversionistas de carácter individual, dueños de fábricas o dedicados a la construcción del ferrocarril, en las primeras décadas del siglo XX. Cabe mencionar que la presencia de esta población en Honduras se remonta desde el último tercio del siglo XIX. Según Antonio Canelas Díaz (1999), en la ciudad de La Ceiba se estableció una pequeña comunidad antillana. En su mayoría eran oriundos de Jamaica, vivían en su propio "Barrio Inglés," asentamiento que se remontaba a la década de 1870, y habían sido contratados por las primeras empresas bananeras para administrar las transacciones de compra y carga del banano desde la costa caribeña (pp. 67-71).

Para Jorge Amaya (2007):

El origen histórico de los negros ingleses o creoles, [...] desciende de dos contingentes que llegaron en oleadas diferentes: la primera a raíz la introducción de esclavos negros de Jamaica, Caimán y Belice por parte de los británicos entre finales del siglo XVIII y mediados del XIX, y luego, el segundo contingente con la llegada de obreros negros procedentes de Jamaica y otras islas anglófonas arribados en los albores del siglo XX para laborar en las empresas transnacionales del banano (p. 117).

Esta misma tesis la defiende Glen A. Chambers (2010) en su obra Race, nation, and west indian inmigration to Honduras, 1890-1940 (p. 10), planteamiento que también lo comparte Darío Euraque (2008). Euraque expone que, con la expansión de la industria bananera, arribaron mediante permisos especiales, más antillanos, y muchos de ellos trabajaron como jefes y sub-jefes en los muelles donde se cargaba la fruta y donde solían ser "inspectores de fruta", "capataces de muelle" y de sus estibadores; o jefes de campo, como manifiesta Soluri (2013, p. 242). Según Euraque (2008), la comunidad antillana en La Ceiba entre las décadas de 1920 y 1950 se diferenciaba mucho de aquella residente en las ciudades 
de Tela en el mismo departamento, o de Trujillo, en el departamento de Colón, quienes vivían en sus propios barrios y no ostentaban la magnitud de los clubes y logias sociales que existían en La Ceiba para este entonces.

La presencia y rechazo hacia esta población aumentó cada día al promoverse contratos temporales para los trabajos en las líneas férreas y la construcción de muelles. Por ejemplo, en 1916, se registraba el ingreso de hasta "400 negros por mes" (Anales del Archivo Nacional, 1971, p. 62; Mejía et. al.,1994, pp. 26-27). A pesar de este dato, su presencia fue mínima con relación a la clasificación étnica, según los datos de los censos producidos entre 1910 y 1930. Sin embargo, estas estadísticas oficiales no son confiables porque contribuyeron a fomentar un discurso oculto, y quizá forzaron las categorías raciales para demostrar que Honduras, para estas dos décadas, había transitado de ser una nación ladina a una nación mestiza. ${ }^{75}$

Se puede hacer una aproximación si consideramos que la población registrada como "obreros del banano y del ferrocarril" en 1912 era de 2.500 dedicados a las actividades del banano, y ya para 1930 había aumentado a 22.000 ${ }^{76}$ (Posas, 2016, pp. 102-103; Euraque, 1990, p. 166; Euraque, 2003, p. 38; Acuña, 1993, p. 260). Ello sin contar las familias vinculadas. Este dato debe revisarse en el censo de 1910, el cual muestra un porcentaje mínimo de población negra y mulata de $6,7 \%$, la cual se redujo a 2,5\% en 1930. Ahí se incluía a los negros antillanos de habla inglesa, de la cual apenas 3,0\% en 1910 y 2,5\% para 1930 se considera población garífuna o de negros coloniales, ubicados en su mayoría en los departamentos del Caribe, principalmente en las ciudades y puertos conectados

\footnotetext{
75. Ver Archivo Nacional de Honduras, Tegucigalpa (ANH), Dirección General de Estadística, Tegucigalpa, Tipografía Nacional, 1911, Breve Noticia del Empadronamiento General de Casas y Habitantes de la República de Honduras Practicado del 18 de diciembre de 1910...; y ANH, Dirección General de Estadística, Tegucigalpa, Tipografía Nacional, 1932, pp. 54, 64, 72, 80, 88, 98, 108, 116, 124, 132, 140, 148, 156, 164, 174 y 184, Resumen del Censo General de Población levantado el 29 de junio de 1930; y Darío Euraque, Conversaciones históricas con el mestizaje..., pp. 25, 34-35, 174 y 175.

76. Para estos datos debe revisarse, Archivo Rosario Mining Company, Municipio de San Juancito, Francisco Morazán (ARMCSJFM), Listado de obreros viejos y nuevos en documentos sueltos, firmado por el Cajero, 1928-1960 y 1948-1950; ANH, Tegucigalpa: Talleres Tipo-Litógrafos Ariston, 5 y 6, Informe de la Comisión Especial sobre la verdadera situación de los trabajadores hondureños, 1959.
} 
El Caribe hondureño y su negritud:

¿una amenaza para los obreros o un peligro para la nación?

con la economía de plantación de banano y el ferrocarril. Dato que puede validarse en lo expuesto por Euraque (2004, pp. 174-175).

Según el planteamiento de Euraque (2008), para estos años de 1930 quizá residían en todo Honduras, incluyendo las Islas de la Bahía, solo 2.000 negros ingleses, aunque un mínimo porcentaje laboraba en la infraestructura portuaria en Tela, La Ceiba y Trujillo (p. 10). ${ }^{77}$ Para el año siguiente, según este autor, solo la UFCo contaba con 4.300 obreros en los departamentos de Atlántida y Colón, de los cuales aproximadamente 420 obreros eran extranjeros, en su mayoría antillanos. Esta situación persistía para mediados de esa misma década. ${ }^{78}$ Ya para entonces, las compañías transnacionales se habían abstenido de contratar negros ingleses, decisión que se había considerado por lo establecido en la Ley de inmigración de 1929 y sus disposiciones, que continuaban aún reformando esta ley en $1934,{ }^{79}$ y también por la presión de las organizaciones obreras y la prensa.

Los datos muestran una población, en su mayoría, de obreros, con una identidad mestiza y de hondureños. Sin embargo, habrá que seguir escudriñando las fuentes y ver hasta qué punto el Estado intentó mantener un discurso oculto, complementado con una infraestructura legal e institucional con la pretensión de ofrecer una imagen de nación homogénea, visto desde una contribución del Estado moderno y desde el "progreso continuo", tal como lo plantea Mamdani (2012). Ello lleva, según este autor, a reflexionar el momento en que se transita de un nacionalismo incipiente en el siglo XIX a una consolidación del Estado liberal, pero con la desnacionalización de la economía, a través de una legislación de migración, el registro estadístico de la población y la inclusión de categorías en los censos como instrumentos que conducen a formar la nación homogénea.

77. ANH, el Censo de 1930 donde se había registrado más de mil. ANH, Carlos Zúniga Figueroa, Dirección General de Estadística y Censo, 3, Estadísticas Demográficas, 1926-1951, 1953.

78. ANH, República de Honduras, Tegucigalpa, Tipografía Nacional, 1936, 18 y 19, Informe de Fomento, Agricultura y Trabajo, 1934-1935; y ANH, República de Honduras, Tegucigalpa, Tipografía Nacional, 1937), pp. 23, 25-26, y 37-38, Informe de Fomento, Agricultura y Trabajo, 1935-1936.

79. State Departament Records, National Archives, Washington, United State (SDRNAWUS), Record Group 59, 815.55/978-999; Grupo de Registro 59, Registros Generales del Departamento de Estado. Copia microfilmada no. T-477, carrete microfilmado no. 4, Decreto del 30 de marzo de 1929. 
Por lo expresado anteriormente, es importante exponer qué dicen otros instrumentos oficiales emitidos por parte del Estado, tales como la legislación migratoria y de concesiones y los convenios o concesiones entre el Estado e inversionistas. En ellos hay disposiciones con un discurso explícito no solo referente a la colonización, sino a la regulación y rechazo de población "exótica", refiriéndose a negros de habla inglesa (antillanos), chinos y colíes, pero con mayor insistencia en contra de los antillanos. En esta normativa, se encuentra lo que plantea Mamdani (2012), el despojo de las tierras, la segregación y la construcción de una identidad homogénea del mestizaje, negando así al sujeto negro de habla inglesa como parte de la construcción del Estado moderno y consumando una diferencia forzada en un escenario de colonización (pp. 2-4, 31 y 43).

Hay que mencionar que antes de la construcción de un discurso jurídico se habían iniciado manifestaciones referentes a la inmunidad en un escenario de epidemia y de ser agentes de contagio en caso de algunas enfermedades. Tal situación solo se había expresado con mujeres que ejercían la prostitución, a quienes se reconocía como posibles agentes de contagio de enfermedades, y por tener una "conducta inmoral". ${ }^{80}$ Después de 1903, este estigma se extendía a la población de origen africano, y si se trataba de enfermedades sexuales se les atribuía ya no solo a las mujeres prostitutas, sino a los negros antillanos, trabajadores en las bananeras, y a sus familias.

Entre 1905 y 1906, durante la propagación de fiebre amarilla en el departamento de Cortés se construyó un discurso de inmunidad de las poblaciones de origen negro en general. Esta epidemia entró por Puerto Cortés, contagiándose la población de las comunidades cercanas al Ferrocarril Nacional (Choloma, Chamelecón, Pimienta, San Pedro Sula y Villanueva) durante casi tres meses. Para tal emergencia se emitieron las correspondientes medidas sanitarias en cada una de las ciudades del Caribe hondureño, entre ellas: San Pedro Sula, La Ceiba, Trujillo y Roa-

80. Ver Centro de Documentación de la Carrera de Historia, UNAH, Tegucigalpa (CDCHUNAH), D. Gutiérrez, Juan E. Paredes, Alejo S. Lara, Asamblea Nacional Constituyente, Diario de las sesiones, Actas centésima nonagésima quinta sesión de la Asamblea Constituyente, Tegucigalpa, 25 de mayo de 1895; CDCH-UNAH, núm. 217, 1773-1776, Diario de las sesiones, Tegucigalpa, 30 de mayo, 1895; y ANH, Miguel O. Bustillo Vicepresidente del Congreso, 11, La Gaceta, Tegucigalpa 22 de junio de 1895. 
tán. La cantidad de víctimas contagiadas y fallecidas motivó que autoridades sanitarias y políticas manifestaran temor y que consideraran a las poblaciones de color u origen "negro" como los individuos inmunes que, por tal razón, deberían colaborar en tareas de atención a la epidemia. En la ciudad de San Pedro Sula, en el departamento de Cortés, su alcalde municipal, Antonio Guillén, mediante comunicación al gobernador político, le solicitó se aprobara "el pago de seis negros que se ocuparan para sepultar a los que han muerto de fiebre amarilla [...]"81 En cambio, en la ciudad de La Ceiba, en el departamento de Atlántida, sede la UFCo y de la Vaccaro Brother Company, la Junta de Sanidad emitió varias normativas, entre ellas: suspender el tráfico de pasajeros en los vapores procedentes de Puerto Cortés y otros puertos de Honduras; dar instrucciones para que los inspectores de fruta, contadores y empleados de las compañías que llegaran a bordo de vapores estuvieran obligados a guardar cuarentena en Cayos Cochinos, y acordar que "solamente los ingleses negros y morenos por considerarse inmunes para la fiebre amarilla, podrán llevar fruta de tierra al costado de los vapores". Decisiones que fueron enviadas por el cónsul de Estados Unidos al médico de la oficina de Sanidad de Washington, y a los agentes de las compañías fruteras. ${ }^{82}$

Debido al temor de propagación a otras zonas del Caribe, para los primeros meses de 1906, llegó una misión sanitaria y del comercio de los Estados del sur de EE. UU., entre ellos médicos y representantes de la UFCo y ciudadanos de comunidades cercanas. Todos ellos pretendieron convencer de que estaban de acuerdo en que el Caribe de Honduras era el origen de la epidemia y de él procedían los posibles agentes del contagio. Todo este comportamiento se interpreta desde dos vertientes. Por un lado, se trata de grupos locales, autoridades sanitarias y políticas manifestándose sobre la inmunidad vista desde lo racial; y por otro, entre huelgas y discursos se dio todo un debate sobre la teoría del origen de propagación y el contagio por parte de poblaciones subalternas, ya en un contexto de la salud transnacional, si era el Caribe de Honduras el posible

81. Ver Archivo Histórico, San Pedro Sula (AHSPS), folio 436, Acta núm. 25, Sesión ordinaria de Corporación Municipal, 1 de julio de 1905.

82. Biblioteca Latinoamericana, Universidad de Tulane, Nueva Orleans (BLUTNO), 3, El Pueblo, Resoluciones de la Junta de Sanidad, La Ceiba, 6 de agosto de 1905. 
origen o si se trataba del sur de EE. UU, sin aceptar que ellos también eran posibles agentes de contagio.

Todo ello sucedió a pesar de los contextos y avances del pensamiento liberal y sanitario. Estas reacciones continuaron siendo defendidas por diversos actores y por varias décadas, en este espacio donde se construyeron los intereses del capitalismo en Honduras, conectado a otras zonas de intersección transnacional. Igual actitud la encontramos en distintos sectores, entre ellos la élite política, con la propagación de la malaria. El caso del diputado del Congreso Nacional Ramiro Carvajal fue ejemplar. Él presentó una iniciativa para que se reformara las leyes de inmigración y extranjería, para impedir la invasión de la raza negra, o mejor dicho, su llegada al litoral atlántico, ${ }^{83}$ demanda que se consideró en la Ley de Inmigración de 1929. Las propuestas del diputado Carvajal fueron difundidas por el diario El Cronista en Tegucigalpa, con el titular "El problema de la invasión de color en la costa norte", tratándose de los negros de habla inglesa. El editorial también declaraba que esta población era inmune a la malaria. Percepción que se manifiesta de la siguiente manera.

¿Pueden o no pueden llegar los negros al territorio hondureño, en calidad de trabajadores temporales o de inmigrantes? Esta es la cuestión. La raza negra resiste todas las inclemencias del clima tropical. Por eso la prefieren las compañías bananeras. Con menos jornal, trabaja más que el operario hondureño, porque es más resistente. Para el negro no hay malaria. Los glóbulos de la sangre de un cafre son enemigos personales del microbio del paludismo. Por eso este jamás se acerca al individuo caribe. ${ }^{84}$

Estas expresiones fueron una percepción general sobre la inmunidad a la malaria y las epidemias de parte de diversos sectores: intelectuales, obreros, y la prensa. Incluso en las obras literarias (Pacas Navas, 1992; Carías, 1990; Coello, 1998). En Honduras, ya como un "problema racial", y por supuestamente desplazar a los trabajadores hondureños, fue manifestado además entre estos sectores, tal es el caso de los mismos gobernantes. Ejemplo

83. ANH, Tegucigalpa, 1, El Cronista, El problema de la invasión de color en la costa norte, enero de 1925.

84. ANH, El Cronista, Ibid. 
fueron Miguel R. Dávila, Francisco Bertrand Barahona, Vicente Tosta, Miguel Paz Barahona y Vicente Mejía Colindres, quienes ejercieron la presidencia entre 1907 y 1933. Ellos no solo facilitaron la creación de una legislación y un discurso xenofóbico hacia los negros antillanos, sino que esto se complementó con las reacciones y discursos de las organizaciones obreras, y un sector de intelectuales y la prensa, quienes los veían como un problema para la nación. Esta situación se generalizó en toda Centroamérica, donde había inversiones estadounidenses, expresando que esta población, además de los árabes, palestinos, chinos y colíes, era considerada una amenaza para la composición racial y el tejido moral, particularmente porque la población antillana era portadora de una cultura no deseada. Por ello les negaron sus derechos a ser ciudadanos (Acuña, 1993, pp. 266-267; Green, 2017, pp. 1114). Por tal razón, a estos individuos "operarios de la raza negra" también se les consideraba como una raza despreciada e indeseable, inferiores y nocivos, de piel negruzca, manchada, anémica y enfermiza, traídos a Honduras como carbón o herramientas. Muchas veces fueron catalogados como negros perniciosos e incorrectos e inmigrantes innecesarios (Posas, 2016, pp. 113-121; Acuña, 1993, p. 266; Barahona, 1992, pp. 263-264; Turcios, 1916, cit. por Euraque, 2004, p. 163; Anales del ANH, pp. 62-63).

Todas estas expresiones se volvieron una presión para construir otros conceptos y discursos, legalizados en las normativas de migración y de concesiones, donde se les llama "negros antillanos", "trabajadores extranjeros o negros", "negros de habla inglesa" o "poblaciones exóticas". En estas normativas jurídicas, lo mismo que en los contratos y concesiones firmadas entre los inversionistas y el Estado, se dejó explícito que se debía regular su presencia en Honduras. Estos mecanismos, si bien fueron implementados desde inicios de los gobiernos liberales en el último cuarto del siglo XIX, para promover la inversión extranjera y la inmigración, contienen algunas diferencias con las disposiciones emitidas en las primeras tres décadas del siglo XX. Ya para este siglo, la legislación migratoria y de concesiones emitió un discurso racial y de xenofobia hacia las poblaciones consideradas "exóticas". Esto ocurrió de manera gradual entre 1909 y los inicios de la década de $1930 .{ }^{85}$ Este fue el mismo tiempo 
en que se ubica la injerencia de EE.UU en Honduras (Barahona, 1991, p. 89), y en que una generación de médicos formó parte de la red política e intelectual del imaginario de la nación, entre ellos los prominentes presidentes Francisco Bertrand Barahona (1913-1919), Miguel Paz Barahona (1925-1929) y Vicente Mejía Colindres (1929-1933). Todos ellos participaron no solo en la aprobación de las normativas jurídicas sino también a través de las disposiciones emitidas en los contratos de concesiones, y en expresiones o discursos racistas publicados en la prensa local o informes oficiales. Así sucedió con los presidentes Vicente Tosta y Miguel Paz Barahona. Según informe del cónsul norteamericano en Puerto Castilla, Francklin Morales, en el municipio de Trujillo, sede de la Truxillo Rairoad Company, dirigido al secretario del Departamento de Estado, le comunicó que Vicente Tosta, siendo presidente provisional, se declaró simpatizante de los huelguistas que se oponían a la presencia de los trabajadores negros en la Costa Norte, en julio de $1924 .{ }^{86}$ Este informe también fue reportado por el cónsul norteamericano en la ciudad de La Ceiba, George P. Waller. ${ }^{87}$ Sus ideas fueron difundidas en la prensa nacional.

Un año después del comportamiento de Tosta, Miguel Paz Barahona, siendo presidente de la república, expresó que se debía promover la inmigración de "razas serenas, esencia para paz e indispensable para permanencia de la democracia". Según sus declaraciones, "la sangre es un artículo de primera necesidad [...] debemos importarla" (Paz, 1925). El gobernante se refería a inmigrantes europeos, por lo que no fue casualidad que el proyecto de la Ley de Inmigración de 1929 se creara en su gobierno y se aprobara en el primer año de la presidencia de su amigo y colega Mejía Colindres. Este discurso oficial con componentes racistas y agresivo por parte de los gobernantes se había iniciado en la antesala y luego de aprobada la Ley de Concesiones en 1917, ${ }^{88}$ mientras ejercía la presidencia

de agosto de 1931 (Barahona, 1991, pp. 249 -265); y SDRNAWUS, núm. 847, 815.55/6, Record Group 59, 815.55/978-999, Congreso Nacional, Decreto 101, Tegucigalpa, 30 de marzo de 1929. 86. SDRNAWUS, Grupo de Registro 59, documento 815/5045/51, Despacho núm. 641, Embajador de EE. UU. en Tegucigalpa, Franklin E. Morales, 22 de julio de 1924.

87. SDRNAWUS, RG 59, 815.5045/47, Political Series 20, George P. Waller, American Consul in La Ceiba, to Secretary of State, 14 July 1924, cit. en Green (2017, p. 32).

88. CDCH-UNAH, Congreso Nacional, Boletín Legislativo, Series III y IV, núm. 28-30, Ley de Concesiones, Tegucigalpa, 21, 23, 24 y 25 de abril, de 1917. 
de Francisco Bertrand Barahona, amigo de Paz Barahona y Mejía Colindres, y de toda una generación de médicos autores de las ideas unionistas, defensores de la soberanía y del proyecto sanitario. Varios de ellos fueron diputados en el Congreso Nacional y responsables de la aprobación de este y otros instrumentos jurídicos y de carácter nacional para regular las concesiones. Según esta Ley, a pesar de la necesidad de contratar población para la economía, se debía atender las normas generales y de "colonización". Ahí se dejó estipulado que "en los contratos de concesión se estipulara siempre, que la mitad, por lo menos, de jornaleros u operarios y empleados secundarios de la empresa habrán de ser hondureños". 89 A los inversionistas se les solicitó el compromiso de capacitar a los obreros hondureños para trabajos en las fábricas y la industria. Se dejó:

[...] la prohibición de importar individuos de raza negra o amarilla, y colíes de raza indostánica, para empleados en los trabajos del concesionario.

Sin embargo, para los trabajos de construcción de una línea férrea o sección de ella, o para las plantaciones de algodón en vasta escala, el Ejecutivo podrá permitir la importación de negros en el número y tiempos indispensables, con la obligación de cada uno de los individuos importados, de abandonar el país cuando haya expirado el plazo que se fije para permanencia en él.

El empresario debe también aceptar el compromiso de obligar a dichos individuos a abandonar el territorio hondureño en el plazo señalado. ${ }^{90}$

En esta misma ley se contempla que estas poblaciones al ingresar al país debían comprobar su buena conducta, buena salud y su aptitud para la industria, oficio o empleo que se propusieran ejercer, y si se trataba de casos con enfermedades contagiosas, se debían aislar. ${ }^{91}$ Dichas disposiciones se trasladaron a los artículos de la Ley de Inmigración publicada en 1929, en la cual se manifiesta vigilar la marcha de la inmigración y velar

89. CDCH-UNAH, Congreso Nacional, Boletín Legislativo, Serie III, núm. 28, 219, Ley de concesiones, Tegucigalpa, 21 de abril de 1917.

90. CDCH-UNAH, Congreso Nacional, Boletín Legislativo, Serie III, núm. 28, 219, Ley de concesiones...

91. CDCH-UNAH, Congreso Nacional, Boletín Legislativo, Serie IV, núm. 31, 241, Ley de Concesiones, Tegucigalpa, 25 de abril de 1917. 
por los colonos e inmigrantes, los empresarios y las autoridades para que cumplan con la obligación señalada. Además, se enfatiza en no permitir la entrada de inmigrantes que tuvieran enfermedades graves, crónicas o contagiosas, en concordancia con lo que establecía el Código de Sanidad y el Código Sanitario Panamericano. En el caso de los inmigrantes pertenecientes a las "razas" árabe, turca, siria, armenia y negra e individuos denominados coolies que no estuviesen comprendidos en ninguno de los casos, se les permitía ingresar a la república, siempre y cuando presentaran cinco mil pesos plata cada uno de ellos y un depósito en las oficinas fiscales del Gobierno, de quinientos pesos plata por persona, que les sería devuelto si los depositantes salían del país antes de que hubieran transcurrido dos meses desde la fecha de su ingreso.

Con la emisión de esta ley, el Estado configuró toda una legislación de carácter nacional blindada como una normativa, no solo para regular la migración y la colonización, sino también complementada con la legislación sanitaria y con un claro discurso racial. Se dejaba de manifiesto el rechazo a poblaciones de origen asiático y negros antillanos o de habla inglesa, también conceptualizada como población africana. Era toda una construcción ideológica realizada por un sector de intelectuales y la prensa local y nacional, desde el mismo momento en que se trabajó en la Ley de Concesiones de 1917. Por ejemplo, un año antes de emitida esta normativa, el poeta Froylán Turcios (1916), abanderando de Augusto Sandino (nicaragüense) y del nacionalismo de la segunda década del siglo XX, expresó:

Nunca el país podría soportar largo tiempo la presencia de una turbamulta de negros perniciosos e incorrectos, venidos a Honduras para quitar a millares de hondureños [...] el trabajador Hondureño, que es de raza mil veces superior al negro, es más inteligente y apto para las faenas agrícolas. La mayoría de los hondureños no se imagina cuan perniciosos han sido para el país los negros de extraña procedencia que trabajan y aun trabajan en las fincas de la Costa Norte (como se cita en Euraque, 2004).

Otra reacción sucedió de parte de su amigo, el escritor y periodista Alfonzo Guillén Zelaya, quien en 1931 expresó que "en Honduras la invasión negra desplazaba a los hondureños de manera insistente y humillante"; según él, por peligro de que en el correr de los años, Honduras 
no sea sino una nación de mulatos. ${ }^{92}$ Meses más tarde, el mismo escritor manifestó que los hondureños eran sustituidos por los extranjeros y negros y por ello señaló que urgía dictar medidas enérgicas protegiendo al hondureño. El escritor culpó a las compañías de sustituir a los hondureños por obreros extranjeros, negros antillanos o procedentes distintos otros países. ${ }^{93}$ Cabe mencionar que ambos intelectuales eran originarios del departamento de Olancho, en la región oriental de Honduras, lugar de donde procedía la mayor parte de la población obrera de las plantaciones del banano, ubicados en su mayoría en las ciudades de La Ceiba, en el departamento de Atlántida, Trujillo y Olanchito, en el departamento de Colón. Por tal motivo, sus expresiones eran al parecer una clara defensa a las oportunidades laborales de sus paisanos. Así lo expuso su amiga, escritora y también olanchana Paca Navas de Miralda en su obra Barro (1951; 1992).

Estas reacciones manifestadas por los intelectuales olanchanos se sumaban al discurso promovido por el Estado, donde expresaban el temor por el ingreso de poblaciones trabajadoras y extranjeras no aptas para la imagen de la nación. A ellos les condicionaron su presencia, así lo expresan las disposiciones emitidas en los contratos y en la legislación concesionaria que se firmó y publicó desde 1909. Según los acuerdos, estos debían cumplirse, tanto por las compañías transnacionales del banano y el ferrocarril, como también por aquellos inversionistas de carácter individual. Solo para citar algunos ejemplos.

En una de las concesiones de 1910 aprobadas por el Congreso Nacional, particularmente la que concierne al Decreto núm. 11, se declaró el acuerdo de contrata entre el Poder Ejecutivo y don Félix P. Vaccaro, dueño y socio de la Vaccaro Brothers Company, con sede en la ciudad de La Ceiba. Esta concesión fue una de las tantas firmadas por el presidente Miguel R. Dávila y otros gobernantes para la construcción y extensión del ferrocarril desde la ciudad de La Ceiba a la ciudad de Yoro, en el departamento de Colón. En ella se estableció que el concesionario, con previa autorización del Gobierno, podía "introducir al país para emplearlos

92. ANH, El Pueblo, 1, Alfonso Guillén Zelaya, Protección a los nacionales, Tegucigalpa, 10 de marzo de 1931.

93. ANH, El Pueblo, 1, Tegucigalpa, 3 de agosto de 1931. 
en los trabajos y administración del ferrocarril, los operarios y demás personas extranjeras que necesite, cualquiera que sea su nacionalidad, excepto chinos y negros". Esta concesión fue ratificada en el decreto número 116, del 1 de abril de 1919, ${ }^{94}$ siendo presidente el doctor Francisco Bertrand Barahona. Igual situación se registró en la concesión firmada entre el presidente Bertrand (1913-1919) y el comerciante William N. Zuber, originario de Montenegro y vecino de Trujillo, en 1918. Zuber era dueño de extensas tierras en los departamentos de Atlántida y Colón, donde desarrolló trabajos agrícolas y construcción de ferrocarril. Para ello el gobierno le permitió hacer venir operarios extranjeros, con excepción de chinos, coolies y negros, y para el caso de estos últimos podrían ser importados, pero después reembarcados al vencimiento del plazo. ${ }^{95}$ Ante la amenaza de la llegada de estas poblaciones para los trabajos en las plantaciones de banano, el ferrocarril y las fábricas, el gobierno también establecía que se debía capacitar a los hondureños para convertirse en una mano de obra calificada. Así se manifiestó en la concesión firmada con la ICE SODA WATER y Miguel Brook, para su funcionamiento en la ciudad de Tegucigalpa y en uno de los pueblos del norte de la República, dedicada a la fabricación de cervezas, hielo y aguas gaseosas. ${ }^{96}$ En este acuerdo, el Estado comprometió al concesionario en enseñar por su cuenta a cinco jóvenes de buenas costumbres que tuvieran permiso de sus padres o tutores legales, y que la Secretaría de Fomento designara, el manejo de todas las maquinarias y la manera de elaborar todos los productos de las fábricas. Una vez obtenido el aprendizaje de dichos jóvenes, según se comprobara en el certificado, estos podrían ser sustituidos por otros de las mismas condiciones. ${ }^{97}$ Esta recomendación también se le dio a Honduras Sugar and Distilling, compañía que se estableció en la ciudad

\footnotetext{
94. Tulane University, New Orleans, EE. UU., Standard Fruit Company Paper, 653, Honduras, Box 7, Folder 5, Decreto núm. 116, 2 de abril de 1910; y Folder 27, Decreto número 117, 28 de marzo de 1919.

95. Lousiana Research Collection, Tulane University, New Orleans, EE. UU. (LaRC), Standard Fruit Company Papers 653, Box 7, folder 5, Congreso Nacional, Decreto núm. 74, 26 de febrero de 1918.

96. LaRC, Standard Fruit Company Papers 653, Box 7, folder 27, Decreto núm. 26, 14 de enero de 1919.

97. LaRC, Standard Fruit Company Papers 653, Box 7, folder 27, Acuerdo gubernativo núm. 400, del 21 de enero de 1924.
} 
de La Ceiba, para la fábrica de azúcar, alcoholes y perfumes, ${ }^{98}$ y a todo inversionista que firmaba con el Estado.

Todas estas restricciones se hicieron efectivas tras emitirse la Ley de Concesiones en 1917. Este instrumento que se difundió como una norma de colonización del Estado liberal, y con lo cual los años siguientes hasta que se emitiera la Ley de Inmigración en 1929, fue el marco jurídico en que se amparaban las disposiciones no solo por parte del Estado sino también las reacciones de políticos y las organizaciones obreras hondureñas para rechazar la presencia de mano de obra de origen antillano. Complementado con el discurso oculto promovido en las estadísticas oficiales o los censos de población entre 1910 y 1930, mencionado por Euraque (2004, pp. 34-35 y 174-175), con los detalles tácitamente en estos instrumentos. ${ }^{99}$ De esta manera, los censos contribuyeron en tejer las categorías para homogeneizar la nación en mestiza, desapareciendo a como diera lugar a hombres y mujeres identificados como ladinos, negros y mulatos, incluyendo a los negros antillanos de habla inglesa. Ello se unificaba en un solo lenguaje, en defensa de los obreros hondureños, manifestado por expresiones de políticos, intelectuales y las organizaciones obreras. En ello tuvo un rol importante la prensa local y nacional. En sus editoriales se expuso la necesidad de empleo para los obreros hondureños, o su malestar por el contrato a los negros, o la raza de color, refiriéndose a los antillanos. Incomodidades que se agudizaron entre la década de 1920 y los inicios de la década de 1930 cuando fueron promovidas por el Consejo Directo de la Federación Obrera de Honduras, quienes, desde comienzos de la década de 1920 manifestaban su apoyo "por los obreros del país", y hacían referencia a "la introducción de negros a la Costa Norte del país". ${ }^{100}$ Ya para entonces había una fuerte presencia de organizaciones obreras en la región centroamericana, que defendían y demandaban los derechos laborales y sociales (Martínez, 2015, pp. 53-76).

98. LaRC, Standard Fruit Company Papers 653, Box 7, folder 27, Decreto núm. 26, 14 de enero de 1919.

99. Todo está contemplado en ANH, Dirección General de Estadística, Breve Noticia del Empadronamiento General de Casas y Habitantes de la República de Honduras Practicado del 18 de diciembre de 1910...; ANH, Dirección General de Estadística, Resumen del Censo General de Población levantado el 29 de junio de 1930...

100. ANH, Diario del Norte, 1, La Ceiba, 28 de septiembre de 1927. 
En 1926, el diario El Obrero, de la ciudad de La Ceiba, publica una nota titulada "La Ley de Inmigración y el problema de la raza negra en la Costa Norte”. En él, se declara lo siguiente:

Reconocemos la importancia que tiene para el país el arribo de una sana y selecta inmigración, que venga a darnos el estímulo del trabajo y transmitirnos una cultura superior, pero abominamos de esa inmigración que lejos de beneficiarnos es un peligro para la nación, tanto la completa degeneración que trae a nuestra raza raquítica, como por falseamiento que reporta a nuestras tendencias democráticas.

[...] Casi en todos los países se prohíbe la entrada de individuos de ciertas razas, principalmente de la de color, pero nuestra ley no hace exclusión ni siquiera de estos últimos, y tampoco hay una disposición gubernativa que reglamente siquiera el ingreso de ellos a Honduras.

Cada día aumenta en la Costa Norte el número de los negros, y muy pocos hondureños se han puesto a pensar en el peligro que entraña la propagación de ellos en esa región.

Las compañías en sus concesiones tienen autorización para introducir esa clase de individuos para dedicarlos a sus trabajos, pero bajo ciertas condiciones y previa solicitud al Ministerio de Fomento. Pero esos requisitos no son cumplidos, y cada día vemos aparecen en aquella región, como vegetación espontánea, gran número de negros introducidos de manera clandestina. ${ }^{101}$

Estas declaraciones se dieron previamente a la reforma de la Ley de Inmigración de 1929, al igual que otras expresiones violentas por parte de las organizaciones de obreros y comerciantes locales. Para este año, El Sol, un diario de la ciudad de Tegucigalpa, difundió notas del corresponsal del Puerto de Tela, que exponía cómo se increpaba a los negros hasta amenazarlos de muerte, e incluso se manifestó que el pueblo en general estaba indignado por la gran inmigración de negros que todos los días entran tanto por Cuyamel como por este puerto. Por ello, se solicitaba aplicar medidas drásticas. Y en el caso de no cumplirse, se utilizaría el machete

101. ANH, El Obrero, 1, "La Ley de Inmigración y el problema de la raza negra en la Costa Norte" La Ceiba, 23 de octubre de 1926. 
para echar fuera a la raza indeseable, los negros de habla inglesa. ${ }^{102}$ Lo mismo había sucedido con la huelga de 1924 en Trujillo, mientras gobernaba el presidente provisional Vicente Tosta, según informe del cónsul de EE. UU. en este puerto, quien manifestó que el gobernante apoyaba a los huelguistas. Años después de esta declaración, seguían los discursos de oposición racializada a la introducción al país de trabajadores antillanos. En El Cronista, otro diario de Tegucigalpa, se hacía réplica de notas de 1922, publicadas en el Diario del Norte, y de la Sociedad de Artesanos El Progreso, de la ciudad de La Ceiba, donde mencionaba a la inmigración antillana en los siguientes términos:

La inmigración a Honduras, además de ser escasa, es pésima en cuanto a su valor étnico. Y si realmente nos preocupa nuestro adelanto social, debemos pensar en lo descabellado de la abrumadora afluencia de negros antillanos a nuestras costas. Los altos poderes de la Nación, deben estudiar a conciencia para resolver cuanto antes tan trascendental problema. Mientras las compañías extranjeras estén valiéndose de la inmigración de origen africano, nuestros connacionales, nuestros tristes compatriotas, padecerán de hambre; porque esa inmigración, muy provechosa para empresas aludidas, es altamente nociva para nuestra Patria. La experiencia histórica se opone a este método. La seguridad de nuestros hermanos reclama disposiciones inmediatas y luego después leyes que protegen al hijo del país.

Nuestro malestar interno se debe en mucho a la desmoralización que el elemento antillano aporta, por su ignorancia, por su método sin escrúpulo de competición y por su indiscutible inferioridad como elemento de engrandecimiento social. A la insuperable abundancia del elemento antillano se debe en gran parte, el estado de desesperación a que se ha expuesto tantas veces nuestro pueblo sin protección y sin medios de hacerse referir, por el mismo estado de abandono a que esa preferencia a extranjeros lo ha sumido.

En este caso de gravísima importancia nuestra paz depende quizás en su mayor parte de la solución de semejante mal. Los vicios desgraciados que arruinan a nuestra clase trabajadora, se deben a la miseria en que vegeta.

102. ANH, El Sol, 1 y 4, Tegucigalpa, 27 de febrero de 1929. 
Las compañías extranjeras están en el deber de dar principio a eliminar su preferencia y guardar un poco de mayor miramiento hacia el futuro de nuestra Patria, que les ha abierto sus brazos como madre cariñosa. Debemos ver en el presente las verdaderas causas de nuestra inquietud económica y de nuestra inferioridad social y política.

Ya se palpa el aniquilamiento de nuestro elemento nativo, y esto debe preocuparnos patrióticamente, mucho más que el bienestar aparente que resulta de una inmigración inferior en calidad. El elemento italiano y español son los que más se adaptan a nuestros climas y costumbres y son los que la historia ha preconizado con efectivos.

Con todo respeto y clamor de las clases obreras del país, resolviendo favorablemente el trascendental problema que se presenta en la actualidad, pensando siempre en el futuro de la Patria. Debemos admitir en Honduras ciudadanos de otros países que signifiquen avance social y no retroceso para la nación. ${ }^{103}$

Estas declaraciones de preferir la migración europea concordaban con lo expuesto por el presidente Paz Barahona en 1925, responsable, al igual que el presidente Mejía Colindres, de la Ley de inmigración de 1929. Ya para el año 1930, un año después de aprobada esta ley, el Diario del Norte, de la ciudad de La Ceiba, difundía el siguiente titular: "Por la Raza y por los trabajadores". ${ }^{104}$ En su editorial se refirió a los chinos, negros y colíes como extranjeros indeseables, por desplazar al trabajador hondureño, y de amenaza peligrosísima para nuestra raza y con perjuicio de las generaciones venideras. En otra nota, ese mismo diario difundía "a grandes males, grandes remedios". ${ }^{105}$ Allí se manifestó que, además de indeseables, muchos de esos extranjeros eran de la escuela comunista. Y se expresaba que los negros tenían puestos preferidos, al igual que los norteamericanos, polacos y asiáticos. ${ }^{106}$

103. ANH, Diario el Norte, 1, La Ceiba, 28 de noviembre de 1922. Cit. El Cronista, 1, Tegucigalpa, 28 de septiembre de 1927.

104. ANH, Diario el Norte, 1, "Por la Raza y por los trabajadores", La Ceiba, 3 de noviembre de 1930. 105. ANH, Diario el Norte, 1, A "A grandes males, grandes remedios" La Ceiba, 4 de noviembre de 1930.

106. ANH, Diario el Norte, 1, "Pedimos trabajo para los hondureños", La Ceiba, 20 de diciembre de 1930. 
Pareciera que todas estas presiones fueron consideradas por parte de las subsidiarias UFCo y la Standard Fruit Company, principales contratistas de la mano de obra antillana. Así como lo ratificó el señor R. K. Thomas, gerente de la Tela Railroad Company al gobernador político departamental para finales de $1930 .{ }^{107}$ Según declaraciones difundidas por la prensa local, estas compañías preferían a jamaiquinos y beliceños, a quienes se les identificaba como trabajadores disciplinados en los trabajos de cultivo y el manejo de las fincas, lo que no tenían los obreros hondureños. ${ }^{108}$

Aunado a ello, también se reconocía que sus contratos eran por el manejo del idioma inglés, motivo de desplazamiento de la mano de obra hondureña, tal como se expresó en otro editorial titulado "Primero nosotros, después los demás" ${ }^{109}$ En esta nota el editorial expone que su movimiento era en defensa ante el peligro del hambre para los hondureños y que ahora hasta el idioma inglés de las oficinas bananeras resultaba sobrante, porque contaba con magníficos oficinistas hondureños.

Ante estas presiones, el gerente de la Truxillo Railroad Company, el señor J. F. Dick, con sede en Puerto Castilla, en el municipio de Trujillo, departamento de Colón, informaba al secretario de Fomento, Agricultura y Trabajo que para el año 1930, de 6.416 contratados, 5.463 eran hondureños y centroamericanos, apenas 2 de origen asiático y 678 de origen antillano; esto significaba que ochenta y cinco por ciento de los empleados eran hondureños y centroamericanos, y había un aumento de empleados hondureños de 757 con relación al año anterior. ${ }^{110}$ Un año después, la Standard Fruit \& S. S. Company y sus compañías afiliadas informaban que de 3.983 empleados contratados, 90,33\% eran hondureños y centroamericanos. ${ }^{111}$ Todas estas acciones y discursos se intensificaron

107. ANH, Diario el Norte, 1, "La Gerencia de la Standard Fruit", La Ceiba, 20 de diciembre de 1930. 108. ANH, Diario el Norte, 1, "Atendiendo una necesidad apremiante. Se dice que en la Tela han empezado a cumplir las instrucciones del Poder Ejecutivo hondureño", La Ceiba, 8 de diciembre de 1930; y Diario el Norte, 1, "Porque las compañías bananeras han empleado jamaiquinos y beliceños en sus labores", La Ceiba, 9 de diciembre de 1930.

109. ANH, Diario el Norte, 1, Primero nosotros, luego los demás, La Ceiba, 13 de diciembre de 1930. 110. ANH, Memoria Secretaría de Fomento, Agricultura y Trabajo (SAFT), Año 1929-1930, Tegucigalpa: Tipo-Litografía Nacional, 71, J. F. Dick, Gerente, Informe de la Truxillo Railroad Company, Puertos Castilla, Honduras, 6 de septiembre de 1930.

111. ANH, Rafael Medina Raudales, Memoria Secretaría de Fomento, Agricultura y Trabajo (SAFT), Año 1930-1931, Tegucigalpa: Tipo-Litografía Nacional, 257, A. D. Chute, Gerente Standard Fruit 
luego de aprobadas las reformas a la Ley de Inmigración en 1929. A ello se unió la decisión de eliminar las categorías "ladino" y "mulato" en el censo de 1930 para demostrar que, para este año, 85\% de la población era mestiza en Honduras. ${ }^{112}$ Todos estos mecanismos no solo promovían un discurso oficial, sino de los diversos sectores que rechazaban la presencia de la población negra antillana en el Caribe hondureño. Con ello se forzaba la construcción de una identidad homogénea, lograda por diversas resistencias.

Según Mamdani (2012), esta es una forma de cimentar las diferencias forzadas en los procesos de la formación de los Estados nacionales, promovidas en contextos de las relaciones de dominio de las empresas capitalistas. En Honduras esto sucedió en el escenario de relaciones que provocó la economía de plantaciones de banano, complejidad que según Euraque (2003) puede entenderse como parte del discurso del Estado sobre la construcción de una "Honduras mestiza". Según este autor, en el entendido de que en esta categoría no solo se incluía a los negros de habla inglesa, sino que se trató de convertir en población mestiza a los indígenas. Todo fue parte del mismo contexto de las luchas obreras en la Costa Norte, especialmente como un esfuerzo por generar un "yo colectivo" contra el imperialismo que simultáneamente excluía la negritud de los obreros jamaiquinos y también la negritud garífuna (p. 15).

La interpretación de Euraque habrá que indagarla porque hubo aclaraciones por parte de la prensa local en cuanto a que el rechazo a la presencia negra no se trataba de los nativos, en ello se incluye a los garífunas. Por ejemplo, en una nota del Diario del Norte se difundía que su defensa era por los trabajadores hondureños, y "que el problema negro de la Costa Norte (no aludimos a nuestros negros hondureños ni a otros hondureñizados) es de los primeros a que debe atenderse, pues afecta directamente la vida de nuestros trabajadores nativos". ${ }^{113}$ En estas declaraciones hay cierta ambigüedad porque años más tarde, el diario

\& SS.Co. Informe de la Standard Fruit And Steamship Company, 1931.

112. ANH, Dirección General de Estadística, Breve Noticia del Empadronamiento ... 1910 ...; ANH, Dirección General de Estadística, Resumen del Censo General de Población ... 1930..., y Euraque, 2004, 25, 34-35, 174 y 175.

113. ANH, Diario Del Norte, 1, "El problema Negro de la Costa Norte y las Compañías Bananeras", San Pedro Sula, 17 de septiembre de 1925. 
El Atlántico en La Ceiba reconoce odio "contra los negros" y que "los morenos y caribes hondureños que son nuestros hermanos y que son los que forman la mayor parte de los hombres de color que trabajan en este puerto, muchos de ellos procedentes de las Islas de la Bahía, en donde predomina el idioma inglés". En este caso, también se trataba de población antillana, pero su llegada se presume fue en la primera oleada, entre fines del siglo XVIII e inicios del siglo XIX.

Según Marvin Barahona, las tres primeras décadas del siglo XX fue cuando se dio la construcción de la nación como un proyecto económico donde el Estado hondureño, si bien se mostró dadivoso con las empresas bananeras, también promovió una defensa del principio de nacionalidad, cuando también la prensa hondureña se manifestaba en defensa de la identidad hondureña para no "convertirnos en la cloaca racial de las otras naciones". ${ }^{114}$

Todo este movimiento en defensa de los trabajadores hondureños y "mestizos" se propagó por diversas regiones del Caribe, tal como lo hizo el semanario El Radiograma, publicado en la ciudad de Trujillo, sede de la Truxillo Railroad Company. En una editorial titulaba "El asunto de los negros" 115 y allí anunciaba la llegada de vapores con 150 negros y 90 colíes como una violación a la Ley de Inmigración. Esta nota fue falsa, a tal grado que el director de aduanas de este puerto aclaró: "Ya está en vigor el Artículo 11 de la Ley de Inmigración", refiriéndose a las restricciones de chinos, negros y turcos. También hizo énfasis en que fue el presidente de la república quien permitió desembarcarlos; pero manifestó que quien dudase de sus funciones, "que haga la prueba llegando disfrazado de chino, negro o turco". 116

\section{Conclusiones}

"El problema negro" o de los "operarios de la raza negra", refiriéndose a la población antillana o negros de habla inglesa en el Caribe hondureño,

114. ANH, La Gaceta, 11 de abril de 1930 y el periódico El Pueblo, del 29 de agosto de 1931, 249 -265. Citado en Barahona (1991).

115. Fondo Histórico - UNAH, Tegucigalpa (FH-UNAH), 3, El Radiograma, Año II, núm. 38. Trujillo, 29 de junio de 1930, consultado en https://tzibalnaah.unah.edu.hn/

116. FH - UNAH, 8, El Radiograma, Año II, núm. 30. Trujillo, 3 de mayo de 1930. 
tal como lo citaron algunos titulares de los medios de comunicación, se dio en el contexto de mayor auge de las plantaciones bananeras en Honduras. Estas personas fueron parte de una segunda oleada migratoria de trabajadores con experiencias en trabajar en actividades de plantaciones, con prácticas culturales que se convirtieron no solo en una amenaza a las oportunidades de los obreros hondureños, sino también como un peligro para la llamada "raza" o a la imagen de la nación racializada, según una hegemonía mestiza indo-hispana.

Si bien la historiografía hasta cierto punto lo ha manifestado, faltaba triangular los discursos implícitos y explícitos en todo un marco jurídico y de actores involucrados, en el sentido que lo plantean Hall y Mandami. Según ambos autores, en el proceso de la formación de los Estados se construyen normas coloniales y raciales que incluyen las prácticas discursivas, el idioma y el marco jurídico a favor de nativos y de los colonos. En Honduras esto sucede en un segundo momento cuando se promueve la imagen del Estado moderno. El justo momento cuando se aprueba la reglamentación que condiciona la presencia de la población antillana, por ser considerada esta como una amenaza al imaginario de la nación. Es curioso que el marco jurídico emitido está vinculado entre la legislación de inmigración, concesionaria, y de la sanidad nacional e internacional (del panamericanismo). Su contenido unificó las reacciones y discursos de diversos actores, entre ellos, obreros e intelectuales, con el objetivo de construir un discurso racial y de colonización, disfrazado, si se puede, de manifestaciones a favor de los obreros hondureños, aprovechado para configurar y oficializar una identidad mestiza, como una forma de contribuir a la imagen de la nación moderna y forzar una identidad homogénea.

La presión fue intensa entre los años 1909 y 1933. Justo el tiempo cuando también se dio todo el proceso de la hegemonía de EE. UU. en Honduras. Durante estos años, los gobernantes permitieron la mayor presencia del Gobierno estadounidense en decisiones políticas y ayudas económicas para resolver problemas económicos. Fue el período en que se consolidó una "hegemonía estadounidense", cuando se intensificaron las firmas de concesiones a favor de los inversionistas del banano, el ferrocarril y otras actividades agroindustriales. Fue además el escenario en que fueron responsables la misma red política e intelectual que gestó el imaginario de la nación. 
El Caribe hondureño y su negritud:

¿una amenaza para los obreros o un peligro para la nación?

\section{Referencias}

Acuña, V.H.(1993). Clases subalternas y movimientos socialesen Centroamérica, 1870-1930. En V. H. Acuña Ortega (ed.), Historia General de Centroamérica (t. 4, pp. 255-323). San José: FLACSO.

Amaya, J. (2004). Re imaginando la nación en Honduras: de la nación homogénea a la nación pluriétnica. Los negros Garifunas de Cristales (Tesis de doctorado, Universidad Complutense, Madrid, España). Recuperado de http:// www.repositorio.ciicla.ucr.ac.cr:8080/bitstream/handle/123456789/297/ TESIS\%20Jorge\%20Amaya.pdf? sequence $=1$ \&isAllowed $=\mathrm{y}$.

Amaya, J. (2007). Los Negros Ingleses o Creoles de Honduras: etnohistoria, racismo, y discursos nacionalistas excluyentes en Honduras. Revista Sociedad y Economía, (12), 115-129.

Anales del Archivo Nacional (1971). Se introducen 400 operarios de la Raza negra cada mes, $\mathrm{V}(10), 62$.

Barahona, M. (1991). Evolución histórica de la Identidad Nacional. Tegucigalpa: Editorial Guaymuras.

Canelas Díaz, A. (1999). La Ceiba, sus raíces y su historia (1810-1940). La Ceiba, Tipografía Renacimiento.

Canelas Díaz, A. (2001). El Estrangulamiento económico de La Ceiba, 1903-1905. La Ceiba, Editorial Procultura.

Chambers, G. A. (2010). Race, nation, and west indian inmigration to Honduras, 1890-1940. Luisiana: Lousiana State University Press.

Elvir, R. A. (2000). La Villa de Triunfo de la Cruz en la Historia llamada Tela desde 1829. San Pedro Sula: Centro Editorial.

Euraque, D. A. (1990). Merchants and Industrualists in Northen Honduras: The making of a national Bourgeoisie in peripheral capitalism, 1870-1972. Madison: The University of Wisconsin.

Euraque, D. A. (1992). Zonas regionales en la formación del Estado hondureño, 1830s-1930s: el caso de la Costa Norte. Revista Centroamericana de Economía, (39), 65-102.

Euraque, D. A. (1995). Los recursos económicos del Estado hondureño, 18301970. En A. Taracena y J. Piel (eds.), Identidades nacionales y Estado moderno en Centroamérica (pp. 137-138). San José: Editorial de la Universidad de Costa Rica.

Euraque, D. A. (1996). Estado, poder, nacionalidad y raza en la historia de Honduras: ensayos. Tegucigalpa: Ediciones Subirana. 
Yesenia Martínez García

Euraque, D. A. (2003). 200 años de Categorías Raciales y Étnicas en Honduras, 1790-1990s (ponencia ante la Tercera Conferencia Internacional de Población del Istmo Centroamericano, Centro Centroamericano de Población, Universidad de Costa Rica, 16-19 de noviembre.

Euraque, D. A. (2004). Conversaciones históricas con el mestizaje en Honduras y su identidad nacional. San Pedro Sula: Centro Editorial.

Euraque, D. A. (2008, inédito). Negros Ingleses en Honduras, 1930s-1950s. Apuntes.

García Giráldez, T. (2005). La Patria Grande Centroamericana: La Elaboración del Proyecto Nacional por las Redes Unionistas. En M. Casaús y T. García Giráldez (eds.), Las redes intelectuales centroamericanas: un siglo de imaginarios nacionales (1820-1920 (pp. 123-205). Guatemala: F\&G Editores.

Guevara-Escudero, J. (2007). Honduras en el siglo XIX: su historia socioeconómica 1839-1914. Tegucigalpa: Fondo Editorial UPNFM.

Green, C. E. (2017). Journey to Banana Land: Race and Gender in AfroCaribbean Labor Migration to Honduras and the United States (tesis de doctorado, University of California, San Diego, Estados Unidos). Recuperado de https://escholarship.org/uc/item/4hr5f6pd.

Hall, S. (2017). The Fateful Triangle. Race, Ethnicity, Nation. Cambridge: Harvard University Press..

Herranz, A. (coord.) (1998). Educación Bilingüe e Intercultural en Centroamérica y México. Tegucigalpa: Editorial Guaymuras.

Mamdani, M. (2012). Define and Rule: Native as Political Identity. Cambridge: Harvard University Press.

Maradiaga, A. et al. (2019, inédito). Extranjeros en La Ceiba: su influencia en el cambio demográfico y urbano (1904-1935). Carrera de Historia, UNAH, Tegucigalpa, 8 de marzo.

Martínez García, Y. (2015). La seguridad social en Honduras: actores sociopoliticos, y raíces históricas de su crisis. Tegucigalpa: Editorial Guaymuras.

Mejía, A. et al. (1994). La Truxillo Railroad Company y la Municipalidad de Trujillo (monografía de pregrado no publicada). Universidad Nacional Autónoma de Honduras, Tegucigalpa, Honduras.

Navas de Miralda, P. (1992). Barro. Tegucigalpa: Editorial Guaymuras.

Pastor Fasquelle, R. (1990). Biografía de San Pedro Sula. Tegucigalpa: DIMA.

Posas, M. (2017). Las luchas de los trabajadores hondureños organizados (18801993). Tegucigalpa: Editorial Universitaria. 
El Caribe hondureño y su negritud:

¿una amenaza para los obreros o un peligro para la nación?

Soluri, J. (1998). Landscape and Livelihood: An Agroecological History of Export Banana Growing in Honduras, 1870-1975 (Tesis de doctorado, University of Michigan, Michigan, Estados Unidos). Recuperado de https://deepblue.lib. umich.edu/handle/2027.42/131101.

Soluri, J. (2016). Culturas bananeras. Producción, consumo y transformaciones socioambientales. Bogotá: Siglo del Hombre Editores; Universidad Nacional de Colombia. 


\title{
Migraciones caribeñas de las colonias inglesas hacia Costa Rica y República Dominicana: procesos raciales y el impacto de las ideas de Garvey (1872-1950)
}

\author{
Reina Rosario \\ Universidad Autónoma de Santo Domingo
}

El debate sobre lo que se conoce como crisis migratoria tiene un componente racial que desde hace siglos se repite en

leyes, discursos y prácticas.

JORGE MAJFUD ${ }^{117}$

\section{Introducción}

Impulsado por los vientos alisios, Cristóbal Colón llegó a la isla que los taínos, en arahuaco, llamaban Haití, la cual nombró La Hispaniola y es hoy Santo Domingo. Está ubicada en el corazón de una cuenca que, al mismo tiempo, es archipiélago, mar y también una etnia. En honor a la etnia caribe más adelante se le dio ese nombre a la región. ${ }^{118}$ De este modo, el Caribe, y en especial la isla

117. Escritor uruguayo-estadounidense. Correo de la UNESCO, 2019-2, "El racismo no necesita racistas".

118. La visión de los cronistas sobre la etnia caribe está en cuestionamiento. "Carece de rigor científico todo estudio del Caribe que desconozca sus antecedentes prehistóricos y su construcción como concepto geográfico, histórico y cultural. Por tanto, su estudio científico implica superar los prejuicios colonialistas, e integrar una visión que incluya mar, islas y costas continentales, así como cuestionar la veracidad de las crónicas europeas sobre el contacto indo-hispánico y la colonización a la luz de la arqueología y la etnografía".[...] "La historiografía colonial y republicana trató a los caribes de manera prejuiciada y con el estereotipo no comprobado por la arqueología de ser antropófagos" 
de Santo Domingo, se convirtieron en la puerta de entrada de los europeos al nuevo mundo: "El Caribe se convirtió muy pronto en el escenario de un colosal choque biológico y cultural que llevó a la catastrófica desaparición de las poblaciones nativas y a la gradual ocupación del archipiélago por gentes de distintas zonas de Europa" (Moya Pons, 2008, p. 11).

Los europeos, mediante el negocio de la trata negrera, esclavizaron a millones de africanos que vendían en América. De esta forma se fue conformando una zona del mundo única por el sincretismo cultural y la hibridación de diversos grupos étnicos como aborígenes, europeos, africanos, chinos e hindúes, entre otros. Ese sincretismo, producto de los efectos colaterales del colonialismo español, inglés, francés, holandés, portugués, danés, etc., construyó las bases de las diferencias raciales. Un estudio de la CEPAL sobre discriminación étnico-racial así lo confirma:

El colonialismo va a ser una fuente primordial para la constitución de las ideas sobre las diferencias raciales. La misma idea de la superioridad racial europea frente a la supuesta inferioridad y salvajismo de los nativos de América serán parte de los procesos históricos de construcción de imágenes culturales de conquistados y conquistadores. (Hopenhayn y Bello, 2001, p. 8).

Las migraciones en el Caribe han sido permanentes; solo han variado las intensidades y las formas. Desde las primeras décadas del siglo XIX, luego del proceso de las independencias latinoamericanas, estas han continuado desde y hacia las viejas metrópolis. Se han diversificado con el tiempo. A partir de la segunda mitad del siglo XIX pasaron a ser comunes las migraciones intercaribeñas temporales, itinerantes, siguiendo los períodos de zafras de los grandes centrales azucareros, y de las grandes construcciones de ferrocarriles y de las cosechas de café, entre otras modalidades. De los diversos y complejos tipos de movimientos de población, las migraciones intercaribeñas despiertan nuestro interés. Son, de hecho, la razón de ser de este estudio.

[..], "La construcción imaginaria del indio caribe como salvaje antropófago justificó el primer etnocidio europeo en América. Para los españoles la diversidad cultural de región fue reducida a la dicotomía de taínos-buenos y caribes-caníbales (Guerrero, 2020, pp. 64-65). 
Tomando como modelo las migraciones antillanas que recibieron los dos países aludidos, se pretende mostrar el particular proceso migratorio en el Caribe durante el período escogido. El mismo muestra lo descarnado de las leyes racistas y la desprotección de los migrantes caribeños que pasaban a depender por entero de una empresa multinacional o de un central azucarero que los contratara. Por lo general, los estudios sobre migraciones se interesan por las características económicas. En el presente caso, interesa priorizar la dinámica de la racialización a que fueron sometidos los protagonistas de tales movimientos y el impacto que sobre estos migrantes tuvieron las ideas redentoras de Marcus Garvey. Analizar este tema permite comprender cómo los fenómenos migratorios han sido permanentes en la región. Y más aún, cuando se hurga en la causa, es casi siempre la misma tanto ayer como hoy: prevenir o salir de la pobreza.

Entre los objetivos del presente trabajo, están:

- Analizar las condiciones sociohistóricas en que se produjeron estas migraciones de antillanos británicos a Costa Rica y a la República Dominicana, a fin de poder explicar cómo dependían por completo de las compañías transnacionales que los contrataban.

- Examinar algunas de las políticas migratorias racistas de estos dos países, para de poder explicar cuáles fueron las estrategias identitarias que les permitieron sobrevivir a los inmigrantes antillanos en un ambiente de hostilidad.

- Mostrar el impacto que produjo en los inmigrantes británicos el movimiento garveyista en Limón, Costa Rica, y en San Pedro de Macorís, en la República Dominicana.

- Identificar algunos elementos que permitan apreciar si la inmigración de los caribeños de las colonias británicas hacia estos dos países terminó siendo integrada, asimilada o segregada conformando un grupo étnico diferenciado.

\section{Hipótesis de partida}

Costa Rica y República Dominicana, ambos países pequeños con baja densidad demográfica, desarrollaron campañas para atraer inmigrantes de origen caucásico, pero fracasaron en lograr la inmigración deseada. 
En ambos, las compañías norteamericanas se impusieron y contrataron mano de obra del Caribe inglés, no deseada por las leyes locales vigentes. En un primer momento, en ambos países, ante el racismo abierto, los inmigrantes asumieron su ciudadanía británica y no mostraron interés en integrarse a los países donde habían llegado. En un segundo momento, en ambos países, los inmigrantes fueron influenciados por el movimiento garveyista, identificándose con sus raíces africanas. Y en un tercer momento, en uno de estos países se produjo una asimilación forzada y, en el otro, una segregación territorial; no obstante, es innegable que en ambos casos hubo transculturación.

Desde un enfoque sociocultural se analiza la situación particular de la construcción del ferrocarril y la industria bananera en Costa Rica y el auge de la industria azucarera moderna en la República Dominicana. Ambos fenómenos propiciaron la llegada de los antillanos británicos a esta parte del Caribe hispánico. Para tratar de mostrar uniformidad en su estructura, este trabajo se centra en el análisis de cuatro variables: la penetración de capital norteamericano, migración intercaribeña, las leyes racistas y la influencia de las ideas de Marcus Garvey. Esto a sabiendas de dejar aspectos de gran importancia como el rol de las mujeres en el proceso de preservar la identidad de los inmigrantes, los aportes culturales, la salud, la religión y el arte, entre otros temas de interés.

Este estudio se basa en diversas fuentes que recogen detalles de estas migraciones intercaribeñas. La motivación para la comparación fue producto de la investigación efectuada sobre las identidades de la población de origen jamaiquino del Caribe costarricense. En la elaboración de esta atrajo nuestra atención las similitudes de ambos países en el comportamiento de los inmigrantes, las leyes racistas, el modus operandi de las transnacionales, así como la forma en que estos inmigrantes fueron impactados por las ideas garveyistas. Sobre estas similitudes nos ocupamos a continuación.

\section{Penetración del capital norteamericano en el Caribe: la llegada de los antillanos británicos a Costa Rica y República Dominicana}

Dos elementos se combinaron para que los flujos migratorios intercaribeños de la segunda mitad del siglo XIX fueran intensos. El primero fueron las condiciones de miseria en que se encontraban los antiguos esclavos en 
las islas del Caribe. Y el segundo, la demanda de mano de obra de las grandes obras en Panamá y Costa Rica, así como el auge de las multinacionales norteamericanas de bananos y centrales azucareros instalados en más de once países de la región, entre estos República Dominicana.

\section{Costa Rica}

En Costa Rica la historia de los pobladores de la región del Caribe fue diferente al resto de los habitantes de la nación. Lo fue, no solo por sus características naturales, sino por su tradición de marginalidad y exclusión. Desde los inicios de la historiografía de este país, Costa Rica fue presentada como el paraíso de Centroamérica. Pero este paraíso solo comprendía el Valle Central y no se extendía al este del país, al litoral Caribe. El imaginario nacional costarricense no incluye a los diversos grupos indígenas, a los mulatos ni a los negros localizados en la región del Caribe. Esto lo expone un autor como Víctor Hugo Acuña (2001), cuando señala:

Costa Rica fue forjada en el espejo de los otros países centroamericanos, presentaba las siguientes señas de identidad en aquel momento: la homogeneidad racial, es decir, una población mayoritariamente blanca, de cepa hispánica o europea y la buena distribución de la propiedad de la tierra; tenía más maestros que soldados; era civilista y democrática y amante de las leyes y el orden (pp. 8 y 2).

El Estado costarricense se interesó por la región del Caribe solo a fines del siglo XIX con el propósito de construir un ferrocarril para comercializar la producción cafetalera del Valle Central hacia Europa. Con ese propósito, en 1871 el presidente Tomás Guardia firmó un contrato con el empresario norteamericano Henry Meiggs para la construcción de un tramo de 150 kilómetros de ferrocarril. Pronto el contrato fue transferido a Henry Meiggs Keith y a Minor Cooper Keith, quienes emprendieron la tarea de establecer la línea férrea a Limón (Casey, 1979, p. 21).

Con la entrada del capital norteamericano a Costa Rica y la necesidad de abundante mano de obra, no solo se modificó por completo la economía de la región, sino también la composición etnocultural. La búsqueda de mano de obra para el ferrocarril cesó cuando, en la última década del 
Migraciones caribeñas de las colonias inglesas hacia Costa Rica y República Dominicana: procesos raciales y el impacto de las ideas de Garvey (1872-1950)

siglo XIX, luego de experimentar con trabajadores de diversas procedencias, la compañía comprobó que los jamaiquinos, además de la ventaja de ser angloparlantes, tenían experiencia y mostraban responsabilidad en el trabajo. A esto se unía el hecho de que en Jamaica se pasaba por una profunda crisis económica que expulsaba a los jamaiquinos a buscar trabajo fuera de sus fronteras. La construcción del ferrocarril ${ }^{119}$ presentó problemas económicos durante los primeros años. A causa de esto, el 13 de julio de 1883 se firmó el contrato Soto-Keith, que significó la pérdida de control nacional del ferrocarril, a cambio del refinanciamiento de la deuda externa de Costa Rica, como lo expone Soto Quirós (2006):

[...] con la construcción de un tramo de 84 kilómetros de vía férrea, el contrato cedía a Minor C. Keith el arrendamiento por 99 años de 148 kilómetros de ferrocarril construidos; la propiedad de 800,000 acres ingleses de tierra virgen, localizados a ambos lados de la línea o en otros sitios del país; la exención de impuestos para la importación de materiales para construcción y la exención para las tierras cedidas, durante veinte años. El contrato fue aprobado por el Congreso Nacional en abril de 1884 (p. 8).

Según señala Watt Stewart (1991):

Minor Cooper Keith entendió lo ventajoso que sería el contrato del ferrocarril si se coordinaba con el negocio del banano. Esto marcó el inicio de la producción bananera para la exportación, que luego convertiría el país en un enclave bananero, y la fecha simbólica en la cual nació el dominio imperial norteamericano en Costa Rica (p. 32).

Los obreros jamaiquinos empezaron a llegar desde 1872 y el flujo se mantuvo hasta la década de 1920. Las cifras sobre el volumen de la inmigración varían entre los estudiosos del tema. Jeffrey Casey (1979) señaló: "Para 1904 se declaró que la United Fruit Company tenía unos 4,000 jamaiquinos, y un

119. "El Ferrocarril al Atlántico duró casi 30 años en terminarse y el del Pacífico solo 13; eso habla de las grandes dificultades que enfrentó el primero. Por eso se dice que el ferrocarril al Atlántico es quizá la obra de infraestructura e ingeniería más importante de la historia de Costa Rica; no ha habido otra de esa envergadura ni desarrollada en circunstancias como las de entonces". htps:// img.europapress.es/fotoweb/fotonoticia_20180823121908-1808712599_999.jpg 
total de 5,600 empleados en sus listas mensuales de pago. Ya en 1927 había en Limón 19,136 jamaiquinos" (p. 113). Los trabajadores seleccionados, jóvenes, fuertes y sanos, morían prematuramente por las condiciones de explotación a las que eran sometidos. Sin contratos escritos, fueron víctimas del maltrato y de los atrasos de pago. "Unos 4,000 jamaiquinos murieron en las primeras 25 millas del ferrocarril en Costa Rica" (Soto Quirós, 2006, p. 8). Sobre este proceso, Rosario Fernández (2015) apunta:

El Estado costarricense entregó la zona caribeña al enclave bananero y la abandonó por completo a su suerte. La compañía se encargaba de todo lo concerniente a la vida de los trabajadores, de la salud, construcción de caminos y otros servicios básicos. Las construcciones y los servicios oficiales fueron escasos y muy tardíos. Fue en el 1945 cuando el gobierno creó por decreto en la costa del Caribe el Colegio de Segunda Enseñanza que inició labores en marzo de 1946 (p. 89).

La composición étnica de estas escuelas refleja el cambio que hubo en la provincia con la llegada de los costarricenses. "En estas escuelas, al inicio, predominaban alumnos negros. Posteriormente, durante la década del cincuenta, los negros pasaron a conformar el 50\% del alumnado" (Soto Quirós, 2006, p. 9). Este hecho convirtió a estas escuelas en espacio de socialización de la población de origen jamaiquino con los demás grupos étnicos de la región.

\section{República Dominicana}

Fue en la década del 70 del siglo XIX cuando surgió la industria azucarera moderna en la República Dominicana. Pero es preciso resaltar que hubo unos pininos durante la década anterior. La industria azucarera dominicana renació en la región meridional en la década de 1860, en la zona comprendida entre Azua y la capital nacional, y se expandió hasta la provincia norteña de Puerto Plata, pero no fue hasta la Guerra de los Diez Años en la Gran Antilla (1868-1878), con la migración de unos 3.000 cubanos y otros extranjeros residentes en ella (por ejemplo, del norteamericano Alexander Bass), cuando se contó con el capital, los empresarios y la tecnología para el despegue de su desarrollo (García, 2005, p. 181). 
Es cierto que la llegada del capital y los técnicos cubanos fue importante. Pero a ello se sumaron otros factores indispensables como el interés del Estado, que en 1876 dictó una ley para el fomento de la industria azucarera, concediendo exoneraciones aduanales y, sobre todo, tierras gratuitas a los interesados en fundar ingenios. Eran acciones del Estado encaminadas a atraer inmigrantes para fortalecer la producción. A esto se debe agregar la fertilidad del suelo, abundante agua, al igual que excelentes puertos; como indica Moya Pons (2008): "La República Dominicana ofrecía condiciones favorables. Las tierras eran vírgenes y fértiles, producían dos veces más cañas por hectáreas que las de Cuba y Luisiana. Además, los salarios eran más bajos" (p. 379). Los enclaves azucareros se establecieron, principalmente, en el este dominicano, sobre todo en San Pedro de Macorís, y más tarde en La Romana. Sobre esto, Roberto Cassá (2020) dice: "En 1876 se fundó el primer ingenio moderno, La Esperanza, de propiedad de Juan Delgado, un inmigrante cubano" (p. 347). Los capitales de los primeros ingenios fueron invertidos por puertorriqueños y cubanos. Hubo, además, inversión de capital local en Puerto Plata.

En 1881, el Estado dominicano estableció claramente su propósito de desarrollar una industria azucarera moderna basada en la instalación de centrales azucareros. "Ya para 1882 había 21 modernos ingenios azucareros operando en la República Dominicana, todos funcionaban con máquinas de vapor y algunos con ferrocarriles [...] En 1897, los ingenios contaban con 265 kilómetros de vías férreas" (Moya Pons, 2008, p. 381). Esto permite apreciar el rápido desarrollo alcanzado por la industria azucarera dominicana. El principal problema que enfrentó la industria azucarera moderna fue la escasez de mano de obra. "En el período de 1872 al 1884, se buscó la manera de satisfacer la demanda con trabajadores locales que se obtenía del medio local" (Inoa, 2018, p. 44). Sin embargo, partir de 1884 se produjo una crisis en los precios del azúcar que generó la reducción de los salarios. Desde ese momento, los campesinos dominicanos se negaron a trabajar en los ingenios. En esas condiciones, les resultaba más ventajoso atender sus conucos y producir cacao y tabaco, productos que se vendían a buen precio. La renuencia de los campesinos dominicanos a trabajar en el corte y tiro de la caña hizo que los propietarios de los ingenios comenzaran a buscar otras opciones. Bryan (1973, como se cita en Mota Acosta, 1977) indica el origen de la de 
mano de obra desde las Antillas inglesas hacia la República Dominicana: "En el 1884 se estimó que 5,500 trabajadores nacionales laboraban en la industria azucarera y 500 extranjeros (en su mayoría cocolos ${ }^{120}$ )" (p. 12).

Estados Unidos había mostrado su interés por la República Dominicana muy temprano. "En 1869 inició formalmente el proceso, largo y tortuoso entre Estados Unidos y la República Dominicana, con el fin de proporcionar la anexión del segundo al primero" (Sang Ben, 2020, p. 144). Por diversos factores este plan de anexión fracasó. Pero a finales del siglo XIX, ya consolidada la industria azucarera moderna local, Estados Unidos ideó la fórmula para su penetración a gran escala en la República Dominicana. "La norteamericanización de las centrales azucareras de Cuba, Puerto Rico, República Dominicana, Filipinas y Hawái fue determinante para bloquear en los Estados Unidos la entrada del azúcar de las colonias inglesas" (Moya Pons, 2008, p. 419). Esto provocó en el siglo XIX, desde principios de la década de 1890, la quiebra de la producción de azúcar en las colonias británicas. Fue ese desplome el que empeoró la situación de los habitantes de estas islas, quienes salieron en estampida hacia el Caribe hispano en busca de empleo.

En el año 1892, el Estado dominicano había sido informado mediante una comunicación, de un contrato que tenía el Gobierno local con una compañía holandesa, la cual vendió sus acciones a una compañía norteamericana. La Westendorp notificó que "había transferido sus derechos y obligaciones, incluyendo el contrato de construcción del ferrocarril Puerto Plata-Santiago, a la empresa financiera norteamericana Santo Domingo Improvement Co" (Franco Pichardo, 1996, p. 151). Hacia 1899, los norteamericanos eran propietarios de los ingenios Consuelo, Porvenir, Santa Fe y Asonia, los tres primeros en San Pedro de Macorís ${ }^{121}$ y el último en Azua. A partir de 1899, República Dominicana entró en una profunda crisis por las deudas contraídas durante la dictadura de Ulises

120. Los braceros que migraron desde el Caribe inglés a trabajar en los ingenios azucareros de la República Dominicana llegaron, sobre todo, procedentes de las islas de St. Kitts and Nevis, Tórtola, Antigua, St. Martin, St. Thomas, Jamaica, Montserrat y otras. En su totalidad hablaban inglés, eran protestantes y se asumían como británicos. Los dominicanos les llamaban "cocolos", término que, en sus orígenes, era un apelativo despectivo y racista; hoy el término prevalece sin la carga peyorativa que tuvo por más de ochenta años.

121. Enciclopedia Dominicana, Tomo II, cuarta ed., Editora Centenario, p. 10. 
Migraciones caribeñas de las colonias inglesas hacia Costa Rica y República Dominicana: procesos raciales y el impacto de las ideas de Garvey (1872-1950)

Heureaux con Italia, Alemania, Bélgica y Gran Bretaña. Estas potencias europeas amenazaban con intervenir militarmente para cobrarse su deuda. Estados Unidos ya tenía como meta asegurar su hegemonía en el área a través del "corolario de la doctrina Monroe". Entonces aprovechó esta situación para convencer al Gobierno dominicano de aceptar un préstamo norteamericano para pagar la deuda con los países europeos. Pero esa magnanimidad tenía un precio: los norteamericanos quedaban como tenedores de la nueva deuda. Y para garantizar el pago demandaron la administración de las aduanas dominicanas. Fue así como en 1907 se firmó la Convención Dominico-americana. En este tratado Estados Unidos se reservó el derecho de intervenir militarmente para garantizar la Receptoría General de Aduanas dominicana. De esta forma quedó formalizado el protectorado norteamericano sobre la República Dominicana. A partir de este momento fue vertiginosa la inversión norteamericana. El significado histórico de esta acción lo expresa Cyrus Veeser (2019) así:

La nueva doctrina Roosevelt que elevó a los Estados Unidos al nivel de las grandes ligas del poder tuvo como corolario la reducción de la República Dominicana a una condición de semisoberanía. El abrazo que Washington tendió a principios del siglo XX vendría a apretarse aún más en las décadas siguientes (p. 230).

La inversión norteamericana se aceleró significativamente durante la ocupación militar a República Dominicana de 1916 a 1924. En La Romana, de 20.000 acres en 1911, la South Puerto Rico Sugar Company pasó a tener 144.000 acres en 1920. Es decir, aumentó en $720 \%$. Parte de estas tierras fueron expropiadas violentamente a los campesinos que resistieron convirtiéndose en un movimiento guerrillero conocido como "Los Gavilleros". ${ }^{22}$

De acuerdo con Moya Pons (2008), para 1914, el número de obreros contratados en República Dominicana ascendía a 11.800, originarios de

122. Los gavilleros operaron en la zona este, en su mayoría eran campesinos expropiados que de día hacían trabajo de peones y de noche eran temidos patriotas que defendían la soberanía del pueblo dominicano. Los norteamericanos emplearon todo tipo de medios y armas para vencerlos. Según sostiene Franklin Franco (2008): "Fue aquí donde por primera vez los Estados Unidos emplearon la fuerza aérea contra la población" (p. 437). 
las islas Vírgenes, Islas Turcas, Caicos y Jamaica. Este autor afirma que los ingenios azucareros dominicanos pagaban un dólar por día, lo que representaba un aumento notable sobre los 0,30 por día que se pagaba en el Caribe inglés. Para esa época, los haitianos, aunque en cantidades pequeñas, también cruzaban la frontera con la República Dominicana para trabajar en los ingenios. El censo de 1920 registró en las zonas cañeras 15.013 haitianos, 5.344 de los cuales eran isleños procedentes de las Antillas inglesas. Para 1916, los norteamericanos montaron otro gran emporio azucarero en la región sur, específicamente en la provincia de Barahona. En ese lugar los interventores se apoderaron de manera fraudulenta de 50.000 acres y construyeron así el segundo central azucarero más grande del país. La Cuban Domincan Sugar fue otro de los brazos organizados por el Sugar Trust; ya para 1926 contaba con 10 de los 19 centrales dominicanos. Para la época, las compañías azucareras controlaban 438.182 acres de la mejor tierra dominicana. En 1929, controlaban 92\% de la producción azucarera de este país. Este emporio mostraba un dominio total de la economía dominicana. Fue este crecimiento de la industria azucarera dominicana lo que generó el significativo incremento del volumen de la inmigración inglesa. Según Moya Pons (2008), entre 1914 y 1939, más de 90.000 trabajadores de Nevis y Saint Kitts viajaron a la República Dominicana. El primer censo realizado en este país, en 1920, arroja la información de que en República Dominicana en esa fecha había 5.763 cocolos. El segundo censo, efectuado en 1935, arrojó la cifra de que a la fecha señalada había 9.272 cocolos registrados en el país (Mota Acosta, 1977, p. 19).

El contraste de la cantidad ofrecida por Moya Pons y la que ofrecen los censos dominicanos tiene una explicación lógica. Una parte importante de los que llegaban a República Dominicana a trabajar solo lo hacían durante las zafras. Pero para el "tiempo muerto" volvían a sus lugares de origen. Otros, producto de la transmigración en el Caribe, se iban a distintos países de la región, sobre todo a Cuba, Panamá, Costa Rica, etc. Y, de hecho, volvían a la República Dominicana. Fue precisamente a partir de 1919 cuando los norteamericanos comenzaron a importar mano de obra haitiana. Así lo afirma Israel Cuello (1977) al decir: "A partir de 1919-20 amparados en las Órdenes Ejecutivas mencionadas y propiciados por gobiernos de la Infantería de la Marina Norteamericana, aparecen los haitianos en la estadística de las inmigraciones de braceros" (p. 21). 
La vida de los inmigrantes caribeños, sean estos británicos, franceses o daneses, dependía por completo de los empresarios que recibían la autorización del Gobierno de importar braceros. Las condiciones de vida en los centrales e ingenios, en su gran mayoría, eran infrahumanas; los alojaban en unos barrancos carentes de las condiciones mínimas para una vida digna. Lo mismo para las limitadas condiciones de trabajo en las plantaciones. La indefensión más grande se evidenciaba en el salario de los braceros. El pago consistía en un "vale". Esto era un papel para que una bodega (un comercio) del mismo ingenio le despachara el importe del salario en limitados productos alimenticios. Era algo que mantenía a los braceros atados a la empresa que los contrataba. Un conjunto de obras literarias dominicanas recoge las injusticias de la época. Entre ellas están: Cañas y bueyes, de Francisco Moscoso Puello; Over, de Ramón Marrero Aristy; Los enemigos de la tierra, de Andrés Francisco Requena; El terrateniente, de Manuel Antonio Amiama; y, Tiempo muerto, de Avelino Stanley. En el tiempo muerto (época en que no se muele caña), la sobrevivencia de los braceros era milagrosa. Una idea de las pésimas condiciones de trabajo se percibe en una de estas obras mencionadas:

En esos días conocí la realidad de la vida; la palpé con mi sufrimiento. Desde el primer momento aprendí que lo difícil para el hombre no es el trabajo; más difícil son las condiciones en que se realizan determinadas labores. Y lo peor, lo más tortuoso, lo más deprimente para mí fue cuando entró la tarde, que llegó y me encontró sudado, con el sol ardiéndome en la espalda y sin comer nada. Tenía el estómago totalmente vacío. Tuve que pasarme el día entero así. No probé nada porque no tenía qué comer. Lo único que pude hacer en un descuido del capataz fue pelar una caña y comérmela. Eso fue todo lo que pasó por mi garganta hasta que llegó la noche (Stanley, 2017, p. 50).

La presencia de los inmigrantes cocolos, haitianos y otros antillanos francófonos de todo el Caribe confirma que en la República Dominicana se dieron cita una gran variedad de inmigrantes de distintas procedencias. Y esto permite tener una idea de cómo se enriqueció una sociedad que, de por sí, ya era diversa, dando paso a un conglomerado multicultural. Esta diversidad no termina de ser aceptada por una parte de la élite 
dominante dominicana y quienes arrastran consigo a sectores ignorantes de la población.

\section{Gestiones y fracasos de Costa Rica y República Dominicana para atraer inmigrantes caucásicos}

Costa Rica estaba interesada en poblar zonas baldías de su territorio. Desde muy temprano asumió en parte lo de "poblar es civilizar", que en la región latinoamericana se consideraba exitoso. La ley fundamental que regulaba la inmigración al territorio costarricense había sido promulgada en el año 1862 y fue bautizada con la denominación de Ley de Bases y Colonización. En su artículo 1, inciso 3, estipulaba: "No se permitirá la colonización de 'razas africanas y chinas' y, en caso de que esta inmigración se considere imprescindible, el gobierno queda facultado para limitarla y controlarla". ${ }^{123}$ Se hicieron grandes esfuerzos por conseguir la anhelada inmigración caucásica, la cual, por diversos motivos, terminó en fracaso.

En Costa Rica, a pesar de esa prohibición, fueron justamente los negros jamaiquinos, entre otros, los seleccionados como mano de obra idónea para el difícil trabajo en la región del Caribe. La selección de la mano de obra fue parte de las concesiones que el Estado le otorgó a Keith en el contrato, y hubo que aceptar dicha selección hecha por este norteamericano. Al referirse a este período, Meléndez y Duncan (1972) señalan: "El Estado levantó la prohibición de la inmigración negra y china, decretada en 1862, porque pensaba que, una vez concluida la obra del ferrocarril, estos inmigrantes ocasionales saldrían hacia otra parte" (p. 76). Desde el Estado esta migración fue aceptada como el precio por pagar por el progreso que aseguraba la inversión extranjera en el futuro. Sin embargo, una crisis económica en la construcción del ferrocarril se sentía venir desde 1874 y provocó que muchos inmigrantes tuvieran que dedicarse a la agricultura de subsistencia, permaneciendo en la región.

Documentos y testimonios permiten mostrar cómo los antillanos británicos establecieron circuitos migratorios en el Gran Caribe en el período comprendido entre 1870 y 1920. En un inicio, por razones de construcción del canal de Panamá y el ferrocarril costarricense, el grueso

123. Archivo Nacional de Costa Rica, San José, serie Gobernación, 23426, folio 48, 1850. 
de esta inmigración fue a Panamá y a Costa Rica. "Unos 80,000 hombres y mujeres salieron de Jamaica hacia Panamá durante la construcción del canal en la primera década del siglo, pero solo una pequeña proporción permaneció en el istmo" (Putnam, 2012, p. 368).

A lo largo de toda la costa continental caribeña, así como en las tres Antillas mayores, en donde habían surgido proyectos de construcciones, plantaciones y enclaves, se desarrolló un gran dinamismo con los grandes flujos migratorios de estos antillanos que se trasladaban de un país a otro dependiendo de la demanda de trabajo. A partir de 1915, el abanico de posibilidades se abrió más con las florecientes economías azucareras de Cuba, República Dominicana y Puerto Rico y, como consecuencia, también el flujo migratorio.

La República Dominicana se convirtió en el principal destino para los del Caribe oriental. Unos cuantos barbadenses y santalucenses se abrieron paso hacia Costa Rica en esta época, mientras que unos pocos jamaiquinos se asentaron en la República Dominicana. En un amarillento libro de himnos que yace hoy en la Iglesia Episcopal de San Esteban, en San Pedro de Macorís, está inscrito con letra cuidadosa "Mary Buchanan, Puerto Limón, Costa Rica, 1922". Testimonio silencioso de un trayecto familiar que se fue desde las islas británicas hasta América Central y luego hacia un puerto azucarero dominicano. (Putnam, 2012, p. 375).

Los circuitos migratorios fueron intensos, como lo muestra el gran dinamismo económico de la región del Caribe controlado por el capital norteamericano. Sin embargo, también deja al descubierto lo descarnado del mismo, cuando grandes contingentes de antillanos sumidos en la miseria y el mayor de los desarraigos se convirtieron en obreros itinerantes. En las estadísticas de migración de varias islas, sus nombres quedaron registrados repetidas veces como testimonio de esa migración caribeña itinerante.

\section{La similitud con el caso dominicano}

Para 1871, la población dominicana se estimaba en 150.000 habitantes. La densidad territorial aproximada en el país era de 3,09 habitantes 
por kilómetro cuadrado. El Estado dominicano entendía necesario aumentar la población para poder incrementar la producción y cuidar la frontera con Haití. Se hicieron esfuerzos para atraer familias europeas. "Se dictaron decretos y leyes otorgando franquicias, se crearon Juntas de Inmigración, se firmaron contratos con empresas agrícolas de colonización o dedicadas a su fomento, y se dispuso la exoneración de impuestos a las importaciones de diversos tipos, tanto a compañías como a personas naturales". ${ }^{124}$ Pero los inmigrantes no llegaban. "En 1876, el presidente Ulises Francisco Espaillat otorgó terrenos estatales a todo aquel que los cultivara con uno o más productos como caña de azúcar, café, cacao, tabaco y algodón, entre otros rubros". ${ }^{125}$ En ese mismo año, con el objetivo de atraer migrantes europeos, se impulsaron proyectos para generar atractivas condiciones de vida y se crearon las Juntas de Fomento mediante las cuales el presidente se proponía alcanzar "mejor orden, limpieza, higiene y ornato de las localidades. ${ }^{126}$

En la década de 1880, la industria azucarera dominicana despegó con un ritmo aceptable. Pero, como se señaló anteriormente, a partir de la crisis de 1884, que redujo significativamente los salarios de los campesinos dominicanos, estos volvieron a sus conucos y se negaron a laborar en los ingenios. Tratando de paliar esta situación, el gobierno del presidente Francisco Gregorio Billini en 1883 propuso la entrada de hindúes y belgas para la industria azucarera (Eco de La Opinión, 12 enero de 1883).

Ante la necesidad de obreros, en un primer momento, por cercanía y afinidad cultural, se contrataron trabajadores puertorriqueños. Por ejemplo, en 1883, Juan Serrallés contrató a unos 38 braceros puertorriqueños en su ingenio en San Pedro de Macorís (Álvarez, 2000). Por diversos motivos, esta migración no resultó. La situación se tornaba desesperante. Como una medida adicional, en 1884, el Poder Ejecutivo anunció la creación de una Junta Central de Inmigración presidida por el ministro de Fomento y Obras Públicas. Las juntas de fomento, que se habían fundado

124. Congreso Nacional (1927). "Decreto núm. 263 del Congreso Nacional sobre inmigración abril 1852", pp. 351-353.

125. Congreso Nacional (1929). "Ley núm. 1548 sobre la concesión gratuita de los terrenos del Estado", pp. 89-91.

126. Congreso Nacional 1928). "Decreto núm. 1298 del Poder Ejecutivo creando Juntas de fomento, Santo Domingo, 6 de junio de 1874", p. 69. 
con anterioridad en las comunes, dependerían de ella (El Nuevo Régimen, 8 de agosto de 1900, p. 1). Las juntas del interior destinarían 30\% de los ingresos para el fomento de la inmigración. Se ofrecía tierra, ciudadanía y exoneraciones aduanales a los que vinieran a la República Dominicana. Se señala que esta propaganda se realizaba en países europeos, ya que esa era la población deseada. Este fomento siguió hasta la década de $1890 \ldots$ pero la inmigración esperada de familias europeas no llegaba.

Como la población deseada no llegaba, esto fue lo que hizo que se recurriera al Caribe inglés. Se formalizó la llegada de trabajadores de las islas británicas a suelo dominicano durante el primer gobierno de Ulises Heureaux (1882-1884), bajo cuyo gobierno se fomentó la inmigración extranjera al territorio dominicano. Según Rafael Jarvis (2019), "Ulises Heureaux fue el gobernante que marcó el punto de inflexión respecto a promover el ingreso de braceros inmigrantes que no fueran colonos blancos caucásicos". Esto se produjo "cuando se dejó de lado la idea de atraer colonos blancos europeos [...] para superar la falta de obreros" (p. 70).

En adelante, se instituyó el procedimiento para que los centrales azucareros y colonos solicitaran a las autoridades el permiso para el ingreso de los obreros caribeños. El único requisito consistía en que dichos centrales se hicieran responsables de los obreros. Tal y como ocurría en Costa Rica con el ferrocarril y las bananeras, los centrales azucareros se encargaban por completo de los inmigrantes. Toda su vida dependía de las compañías que los sometían a condiciones infrahumanas y el Estado se desentendía de ellos por completo.

Siguiéndole el rastro a la inmigración nos encontramos que para 1905 fue instaurada una tasa de inmigración mediante la Resolución núm. 4627 del 11 de noviembre del año citado. En la conclusión, el legislador apuntó: "Para los efectos de esta resolución, se concede un plazo de sesenta días a los extranjeros procedentes de Europa y de los Estados Unidos, y de treinta días a los que procedan de las Antillas" (Capdevila, 2004, p. 443). Aquí queda claramente establecida una visión que da una categoría inferior a los inmigrantes antillanos británicos; es decir, esta tasa refleja un mecanismo de discriminación en forma explícita.

Al entrar el siglo XX, según indica Jarvis (2019), "el tema de la preferencia de pobladores caucásicos adquirió de nuevo protagonismo. Quienes opinaban o tomaban decisiones desde el Estado pretendían mejorar 
la raza” (p. 94). Decía F. L. Vásquez, secretario de Fomento, que con ese tipo de inmigración optimizaría las condiciones orgánicas, físicas y psíquicas de la población, razón por la que pretendía injertar en el seno de "la raza dominicana, método, orden y disciplina"... pero la población deseada no llegaba.

En 1912, se promulgó la Ley 5074 de Inmigración. Esta ley establecía: "Necesitan previo permiso para inmigrar al país los naturales de colonias europeas en América, los de Asia, los de África y los de Oceanía, así como los braceros de otra raza que no sea caucasiana". ${ }^{127}$ En otro acápite, la misma ley plantea: "Se prohíbe la entrada de minusválidos, enfermos, anarquistas, asiáticos, africanos, habitantes de Oceanía y de las colonias europeas en América”. Además de la promoción de la inmigración caucásica, en esta ley se percibe claramente cómo el discurso racista aumenta un peldaño más y de manera explícita se rechaza la migración de negros. En una motivación de esa ley se comprueba esta visión claramente racista. "Es tiempo ya de que una ley prescriba todo lo concerniente a impedir que lleguen a nuestros puertos esas hordas de inmigrantes que desgraciadamente nada bueno nos traen" (Inoa, 2018, pp. 71 y 72). Esto último era expresamente para los cocolos. Sin embargo, esta Ley 5074 no detuvo la migración cocola. "En ese mismo año se otorgaron permisos a siete ingenios para traer a seis mil braceros cocolos" (p. 73).

José Israel Cuello (1997) analiza cómo esta Ley 5074 fue refrendada por el gobierno de ocupación norteamericana con tres Órdenes Ejecutivas emitidas en 1919 en relación específica a los braceros. Los norteamericanos, que desde 1915 ocupaban militarmente a Haití, y desde 1916 al territorio dominicano, entendían que "cruzar la frontera era más fácil que un cruce por mar desde las islas inglesas del Caribe y la administración norteamericana rompe las trabas históricas que imposibilitaban el empleo de la mano de obra haitiana" (pp. 20-21). Con esto los norteamericanos muestran su control absoluto sobre los dos países de la isla. Ellos, al mismo tiempo, abrieron el cauce de una nutrida inmigración no registrada y, por tanto, ilegal. Paralelo a esto se puede afirmar que a partir de este momento se inició la sustitución gradual de la inmigración cocola 
Migraciones caribeñas de las colonias inglesas hacia Costa Rica y República

Dominicana: procesos raciales y el impacto de las ideas de Garvey (1872-1950)

hasta llegar a su final, a mediados de la década del 40. La lucha por sobrevivir convirtió a los antillanos británicos en cazadores de zafras azucareras y de cosechas de café. En el período conocido como "la danza de los millones", Cuba llegó a recibir más de 50.369 jamaiquinos. Ya se comentó cómo, solo desde Nevis y Saint Kitts, Santo Domingo recibió 90.000 inmigrantes. Estas cifras indican que constantemente muchos inmigrantes repetían el viaje de ida y vuelta. Existen testimonios de migrantes que entraron más de 30 veces a República Dominicana, trabajaban una zafra e iniciaban su peregrinar hasta volver a la siguiente. Lo cierto es que el desarrollo de la industria azucarera moderna de Cuba y Santo Domingo descansó en el trabajo de los caribeños británicos.

\section{Políticas eugenésicas impuestas por Estados Unidos}

Hasta la década de 1920, los Gobiernos receptores de la inmigración británica antillana la habían tolerado como un "mal necesario". La causa del surgimiento de intolerancia hacia esta inmigración se ha explicado en forma aislada. Sin embargo, Lara Putnam, en Foráneos al fin, ofrece una visión regional y muestra la influencia de Estados Unidos en el repentino cambio de política hacia la inmigración británica caribeña. En 1924 en Estados Unidos fue aprobada la Ley Johnson-Reed que establecía los criterios eugenésicos ${ }^{128}$ y de "asimilabilidad" cultural como los principios orientadores de la política de inmigración estadounidense. Dichos criterios pasaron a regir en la mayoría de los países de la región. Esto se formalizó en la Primera Conferencia Panamericana de Eugenesia y Homicultura efectuada en La Habana en 1927 (Putnam, 2012, p. 289). ${ }^{129}$ A este evento asistieron dieciséis países latinoamericanos, entre ellos Costa Rica y República Dominicana. Allí se unieron en pro de la búsqueda de la fortaleza biológica. Lo curioso de esta conferencia fue que al pretender hablar de homogeneidad racial y del valor eugenésico lati-

\footnotetext{
128. La eugenesia es una visión que propugna "por el mejoramiento de la raza humana [...] está emparentada con el racismo y el maltusianismo" (Rosental y Ludin, 1981, p. 162). Sobre la eugenesia en América, véase, por ejemplo, García González y Álvarez (1999); Miranda y Vallejo (2005).

129. Esta conferencia fue convocada y orientada por un eugenesista cubano que trabajaba de cerca con el estadounidense Charles Devenport, jefe del Eugenics Record Office de la Institución Carnegie, con cuyo apoyo se dio forma a la Ley Johnson-Reed.
} 
noamericano, se incluyera, nada más y nada menos, que al Caribe hispano (Cuba, Santo Domingo y Puerto Rico), países con un amplio porcentaje de población de origen africano. Con esto, como dice Putnam (2012), se trazó una línea tajante de rechazo al Caribe británico. "Las naciones de América dictarán y aplicarán leyes de inmigración destinadas a impedir el ingreso en sus territorios de representantes de razas cuya asociación se considera biológicamente indeseable" (p. 389). Esto dice un fragmento del documento oprobioso que se adoptó al final de la conferencia referida. Como muestra de esta política regional se tomaron medidas y se aprobaron nuevas leyes en los países de la región.

La República Dominicana se acogió a lo planteado en esa Primera Conferencia Panamericana de Eugenesia. Una muestra, entre muchas otras, fue la Ley 338 del 14 de mayo de 1932. En la misma se "rechazaba a los afrodescendientes y asiáticos. La Ley establecía que negros y asiáticos pagaran $\mathrm{RD} \$ 300$ por permisos de entrada y $\mathrm{RD} \$ 100$ por permiso de permanencia" (Jarvis, 2019, p. 130). Estas sumas de dinero, muy altas para entonces dado su exiguo salario, fue otra forma encubierta de impedir la entrada de braceros británicos. Este autor señala que la reacción de cónsules ingleses fue recogida por la prensa dominicana: "El Gobierno Inglés prohíbe en Barbados la emigración de braceros de color a Santo Domingo" (Listín Diario, 25 de mayo de 1932).

Ante la decisión inglesa, los productores azucareros le propusieron al Gobierno que fueran contratados haitianos en la zafra de 1932-1933. Se recuerda que, para ese momento, ya era un hecho la entrada masiva de haitianos promovida desde el 1919 por el Gobierno norteamericano de ocupación. Pero, como consecuencia directa de esta Ley, y ya desde la dictadura trujillista, se hace evidente el cambio de mano de obra inglesa por la haitiana en las provincias de San Pedro de Macorís y en La Romana. San Pedro de Macorís era la ciudad con mayor número de ingenios, por lo que concentraba la mayor cantidad de los inmigrantes cocolos. Lo antes descrito va en correspondencia con la política regional impuesta por Estados Unidos de eliminar o restringir la entrada de inmigrantes del Caribe británico.

En Costa Rica, al igual que en los demás países del área, en medio de la crisis iniciada en 1929, el Estado cambió su política de inmigración extranjera de los años veinte y estableció estrictos controles sobre 
los trabajadores extranjeros. Se creó el "Registro de Identificación Inmigratoria". También, a partir de 1930, se crearon fuertes controles burocráticos y policíacos sobre los extranjeros. Un ejemplo de lo anterior es el artículo 8 de la Ley de Registro de 1930, donde se indica que el extranjero que ingrese al país clandestinamente estará obligado a salir inmediatamente. ${ }^{130}$ Esta ley establecía una distinción entre "extranjeros distinguidos" que son bien recibidos y "extranjeros sospechosos" que aun cuando sean aceptados, era necesario mantenerlos bajo estricto control. En 1931 se aprobó la Ley núm. 39 del 5 de marzo, que establecía que todo inmigrante debía presentar la suma de 1.000 colones en efectivo. El artículo 2 autorizaba al Estado a "rechazar [...] a aquellos inmigrantes que se consideraran nocivos para el país". 131

Como se ha señalado, esto corresponde a una política regional de eliminar o restringir la entrada de inmigrantes del Caribe británico. En varios países de la región, entre ellos Cuba y República Dominicana, los líderes políticos se pronunciaban en contra de la africanización que había propiciado EE. UU., al permitir la entrada en estas islas de inmigrantes indeseables, baratos y explotables de las Antillas inglesas, que les quitaban el trabajo a los nativos. Este discurso refleja que los norteamericanos, a la hora de aplicar cualquier ley o doctrina, solo actuaban en la línea de reafirmar su poder amparados en inversión de capital.

\section{Décadas del 30 al 50: reactivación del racismo bajo el tinte eugenista}

En Costa Rica, en 1930, los diputados debatieron el nuevo contrato de la United Fruit Company con el discurso ya mencionado, denunciando la "africanización" de la zona Atlántica como resultado de la maniobra de los imperialistas" (Putnam 2012, p. 390). Ello respondía a la actitud de las compañías norteamericanas instaladas en América Latina que decidían el tipo de inmigración que permitían en sus enclaves o plantaciones, aunque esto significara echar a un lado las leyes vigentes como ocurrió en Costa Rica y también en la República Dominicana. Así quedaba demostrado que en el Caribe el capital norteamericano obraba con absoluta

130. Registro de identificación inmigratoria, en Leyes y Decretos, 3 de setiembre de 1930, citado por Alvarenga Venutulo (2005).

131. Soto Quirós (2005, p. 126). 
libertad, en beneficio de sus intereses. Sin embargo, diez años después de aprobada la ley migratoria estadounidense de 1924, fue necesario apegarse a ella. Y tanto los países latinoamericanos como las transnacionales norteamericanas se vieron precisados a cumplir con una línea migratoria como era la política eugenesista diseñada por los norteamericanos. En este sentido, hubo una excepción con la República Dominicana, donde Estados Unidos no siguió la mencionada línea política eugenesista, aunque aparentó hacerlo. Comenzó a dejar de contratar a los antillanos británicos, sí, pero en aras de sus intereses económicos, cambió la inmigración cocola por la haitiana, con lo cual también se evidenció que el blanco del rechazo eran los inmigrantes del Caribe inglés.

En 1934, en Costa Rica, una nueva ley ponía de manifiesto el criterio discriminatorio y racista del Estado. Ante el traslado de la compañía bananera del litoral Caribe al Pacífico Sur, la Gaceta Oficial de Costa Rica del 10 de diciembre de 1935 publicó la Ley núm. 31 en cuyo artículo 5o., párrafo 3, señalaba: "Queda prohibido en la zona del Pacífico, ocupar gente de color en dichos trabajos (de producción y explotación bananera)". Más adelante el Estado costarricense continuó con la línea discriminatoria. La misma se reforzó en el gobierno de Calderón Guardia, en 1942, en el cual se aprobó un Reglamento de Inmigración que hizo explícito el impedimento de determinadas personas:

Personas inconvenientes, nocivas o peligrosas al orden o progreso de la República o a la conservación de la raza, ya sea por sus tendencias agitadoras, ya por sus escasos medios de subsistencia o por las características que predominen en ellas y sean de notoria desafinidad con la población nacional (Soto Quirós, 1998, p. 257).

Como se ve, las nuevas leyes de carácter racista, aplicando las "políticas migratorias eugenesistas" asumidas por EE. UU. e impuestas prácticamente a toda Latinoamérica, generaron la disminución significativa de la inmigración de los caribeños ingleses al Caribe y a la mayoría de los países latinoamericanos. Y también propiciaron, de hecho, la segregación espacial de las comunidades existentes en dichos países, aunque no lo hicieran formalmente. Por ejemplo, el lugar de los negros en Costa Rica era Limón; en Panamá era Colón; en República Dominicana era San Pedro 
de Macorís, sobre todo en el barrio Miramar, también en Samaná; y en Cuba, la zona Oriental o Santiago de Cuba (Rosario, 2015, p. 96).

En Costa Rica, las leyes racistas desde 1862 hasta 1942 fueron creando una corriente xenofóbica contra la población negra que impidió por mucho tiempo a los descendientes de jamaiquinos nacidos en ese país obtener la ciudadanía, teniendo que optar por la naturalización (Rosario, 2015, p. 99). La situación de "residente temporal" de los descendientes jamaiquinos nacidos en Costa Rica tuvo un rol significativo en el contexto histórico y social. Por un lado, eso les impedía su participación política como ciudadano, y por otro, después de la Ley de 1934, se les prohibía trabajar en el Pacífico Sur, manteniéndolos en un confinamiento geográfico. Pero la situación cambió inesperadamente con la Guerra Civil de 1948 que sorprendió no solo a Costa Rica, sino a toda Latinoamérica. Producto de este conflicto bélico, y del cambio político que trajo, las políticas estatales hacia la región caribeña cambiaron sustancialmente. La nueva situación se hizo sentir el 4 de noviembre de 1949, día en que la Junta Gubernativa, dirigida por José Figueres, firmó la Ley núm. 836. Esta dejó sin efecto el párrafo 30 del artículo 5 de la Ley núm. 31 del 10 de noviembre de 1934, que prohibía a los negros trabajar en el litoral Pacífico del país. También se emitió una ley que derogaba la discriminación racial en favor del libre desplazamiento en la república. Además, se nombró una comisión especial para el empadronamiento de toda la población de afrodescendientes en Costa Rica con miras a arreglar la documentación que los integrara al libre ejercicio de la ciudadanía costarricense. Y con ello se inició una nueva etapa de la población de origen jamaiquino como ciudadanos costarricenses que sobrepasa el período de este trabajo.

\section{Asimilación forzada en la RD y segregación territorial en CR}

De 1930 a 1950, en la República Dominicana, la situación con los inmigrantes antillanos británicos fue distinta a lo ocurrido en Costa Rica. En 1930, con el inicio de la dictadura de Rafael Leónidas Trujillo, se oficializó una ideología racista que se centró en el antihaitianismo. Pero esa visión segregacionista, por igual, impactó a los cocolos Y también se produjo otro hecho de igual o peor trascendencia, dicha visión repercutió en una gran cantidad de dominicanos que, siendo negros y mulatos, 
sintieron que ese desprecio era a ellos mismos y a su propia cultura. El antihaitianismo trujillista fue patológico. Sobre el tema hemos realizado varios estudios (Rosario, 1989; 2007).

Para inicio de la dictadura, ya muchos descendientes de inmigrantes cocolos habían nacido en la República Dominicana, tanto de padres y madres inmigrantes que eran parejas como en hogares mixtos. Según García y Giannetti (2003), "en silencio, el Gobierno dominicano comenzó un proyecto de asimilación planificada de la población cocola, fundamentado en las necesidades laborales del sector azucarero" (2003, p. 171). Esa acción se puso en marcha cuando los empresarios azucareros solicitaron una exención de la nueva legislación para aquellos extranjeros residentes en el país por cinco años, casados con una persona dominicana, y para residentes por diez años o más que fueran descendientes dominicanos.

De manera sorprendente el secretario de Trabajo ejerció presión para que los cocolos que entraran en esas condiciones asumieran la ciudadanía dominicana. Desde este momento, y más adelante, hubo un grupo de cocolos que se sintieron ante la disyuntiva de ser dominicanos y vivir bajo una dictadura o emigrar hacia Estados Unidos. Los que lograron la segunda opción fueron una minoría, pues por igual para entonces no era tan fácil establecerse en ese país del norte del continente americano. Existen varios elementos que contribuyeron a la confirmación de esta "asimilación forzada". Aquí se señalan solo dos. Primero, de acuerdo con García y Giannetti (2003), "en enero de 1935 el secretario de Relaciones Exteriores, Max Henríquez Ureña, le informó a un alto funcionario de la embajada británica que "el deseo del presidente de la república es evitar que se queden desempleados los cocolos de origen británico"' (p. 66). Trujillo entendía "que casi todos los hombres afectados llevan aquí un número de años y que están levantando sus familias prácticamente como ciudadanos dominicanos". Y segundo, ya para la década de 1940, había una cantidad importante de antillanos británicos residentes en el país que se integraron a las intensas luchas obreras de 1942 y 1946; estos eran seguidores del líder obrero Mauricio Báez. ${ }^{132}$

132. Mauricio Báez fue el líder obrero más importante de la década de 1940. Fue simpatizante de la UNIA y asistió a varias reuniones de esta entidad en San Pedro de Macorís. Dirigió la huelga 
La integración a las luchas reivindicativas, a pesar de que se trataba de un gobierno altamente represor, prueba que ya una parte importante de los cocolos se sentían ciudadanos dominicanos y ejercían sus derechos sin miedo. Esta asimilación forzada por la dictadura también explica la causa de la muerte lenta de las cinco filiales dominicanas de la Asociación Universal para el Mejoramiento del Negro (UNIA). Así fue languideciendo la inmigración cocola hasta llegar a su fin en 1944. La asimilación conllevó el uso del español y, en la gran mayoría de la segunda generación, la pérdida del inglés. Un elemento diferenciador fue que varios apellidos cocolos, en la cotidianidad, fueron adaptados a pronunciaciones en español. Sin embargo, pese a esta asimilación, los aportes de los cocolos han enriquecido a la sociedad dominicana de manera significativa en lo musical y danzario, en la literatura, en lo religioso, culinario, deportivo, artístico y social.

En Santo Domingo, ellos fueron forzados por la dictadura trujillista a la asimilación. Pero esta nunca se da de una sola vía, sino que se convierte en transculturación, donde ambas culturas se enriquecen. Ante esto, unos cuantos logran emigrar a Harlem en NY y se enrolan en la lucha por los derechos civiles (como Carlos Cook). Por su lado, en Costa, Rica a partir de 1934, el cierre de la bananera y la prohibición de trabajar en el Pacífico hizo que muchos afros costarricenses viajaran a Estados Unidos y allí se integraran a los diversos movimientos, en los cuales se identifican con sus raíces africanas y llevan estas ideas y nuevas formas de luchas al Caribe costarricense. La inesperada Guerra civil de 1948 y la llegada al poder de José Figueres los convierte en ciudadanos. A partir de la segunda mitad del siglo XX, se vuelve aún más interesante la comparación de los procesos vividos por estos descendientes de inmigrantes antillanos británicos en estos dos países, pero sobrepasa los límites de este trabajo. Esto deja abierto el tema para futuros trabajos y hacer visible la vida de estos caribeños tan invisibilizados por la historiografía tradicional.

azucarera de 1946 en La Romana y en San Pedro de Macorís, por aumento salarial y una jornada de ocho horas. Por ello tuvo que salir al exilio en Cuba. En 1950, agentes encubiertos de Trujillo lo secuestraron y desaparecieron. 


\section{Influencia del movimiento garveyista en Limón, Costa Rica, y San Pedro de Macorís, República Dominicana}

Marcus Garvey, nacido en 1887 en Jamaica, era descendiente de marroons (cimarrones jamaiquinos). En Jamaica, en 1914, Garvey fundó la Asociación Universal para el Mejoramiento del Negro (UNIA, por sus siglas en inglés), cuyo lema era: "un Dios, un objetivo, un destino". Producto de más de un lustro de trabajo intenso, desde el barrio de Harlem, Nueva York, este movimiento causó un gran impacto en la población negra de todo el mundo a partir de la década de 1920. La esencia de su propuesta era enarbolar la lucha en favor de la dignidad y unidad de la raza negra. UNIA era la estructura a través de la cual se lograría ese objetivo.

Marcus Garvey, escribiendo para el Mundo Negro (órgano noticiario de la UNIA), expuso la filosofía, objetivos y actividades de su organización:

Vamos a crear una sociedad humanitaria, caritativa, instructiva, social e industrial, cuyos miembros se comprometen a hacer todo lo necesario para preservar los derechos de su raza, y a respetar los derechos de toda la humanidad. Una sociedad que crea profundamente en la hermandad de todos los hombres. Una sociedad cuyo lema sería: "Un Dios, un propósito y un destino" (Mundo Negro, serie de héroes africanos, vol. 2, p. 1).

M. Garvey no solo se pronunciaba a favor de la resistencia agresiva y violenta contra el racismo, sino que además lo hacía a través de la fundación de empresas que contrataron más de mil empleados negros. Garvey tenía la idea de que la independencia económica y financiera de los negros era una forma de protección efectiva contra la discriminación. Creía, según Johannes Marek (2004), que "una vez construida una sólida base económica, el movimiento negro podía buscar otros objetivos políticos y sociales, creía que los avances en lo material, operado por negros, contribuiría de manera decisiva a la igualdad de razas hermanas" (p. 158). Su mensaje hacía énfasis en que había llegado la hora de que los negros pudieran desarrollarse por sí mismos y convertirse en hombres y mujeres a quienes se les respete y reconozca su dignidad. Para ello se conformó una red de centros que eran puntos de encuentro, orientación y organización llamados Liberty Halls. En los mismos 
funcionaban cooperativas de asesorías económicas para negocios de la población negra.

La revista Mundo Negro fue fundada en 1919, y Garvey fue editor de esta hasta 1920 (Mundo Negro, serie de héroes africanos, vol. 2, p. 5). Desde el inicio, este hombre de acción enfrentó problemas con los políticos negros. Afirmó: “Tuvimos más problemas con nuestros hermanos políticos que con ninguna otra entidad” (Mundo Negro, serie de héroes africanos, vol. 2, p. 9).

Para 1920, más de cuatro millones de personas se habían afiliado al movimiento. El 13 de agosto de ese mismo año se realizó una convención a la que asistieron más de 25.000 personas. Allí se aprobó la "Declaración de los derechos de los pueblos negros del mundo”. Esta declaración, al igual que los congresos panafricanistas que M. Garvey organizó (1921, 1922, 1924 y 1926 en Harlem; 1929 y 1934 en Kingston, y 1938 en Toronto), fue de vital importancia para el desarrollo de las iniciativas que los delegados de la organización proponían en torno a los temas políticos, económicos y sociales para el mejoramiento de las personas negras (Romero Contreras, 2012).

\section{La UNIA en Limón}

La población de Limón recreaba por doquier su estadía en la provincia cuando trabajó durante dos años en la bananera. La población de origen jamaiquino en el Caribe costarricense fue convulsionada por M. Garvey y por su propuesta de unir a los 400 millones de africanos y de dignificar a todos los negros del mundo. En Limón, como en todos los lugares donde había comunidades negras, solo se hablaba de M. Garvey y de su proyecto. Garvey había vivido en Limón, Costa Rica, donde trabajó entre 1910 y 1911. Esto le permitió conocer desde dentro las condiciones de las bananeras. La colectividad recordaba su intento de organizar un sindicato, lo que le había costado su despido, y esto le dio ante la comunidad gran prestigio y credibilidad.

Las informaciones que llegaban a Limón acerca de cómo prosperaba el proyecto garveyista tenían entusiasmados a los limonenses. En 1920, cuando se difundió la información de que Garvey, ya vuelto un líder, pasaría por Limón, la noticia se regó como pólvora. Los periódicos de la 
capital costarricense dieron cuenta de ese acontecimiento de la siguiente manera:

Vienen a Costa Rica representantes de la Flota Negra. "La Estrella Negra" el Vapor Frederick Douglass que es de "la Flota Negra", el primero que arribará a nuestras costas. La Estrella Negra es una compañía de vapores construida en Delaware, siendo negros los que integran el personal administrativo y representativo de la misma, así como el conjunto de sus trabajadores de mar y tierra y desde el director general hasta el mandadero de cada oficina, y desde el capitán hasta el último tripulante de cada barco (Diario de Costa Rica, 26 de febrero de 1920).

Todo el pueblo estaba conmocionado con la visita de M. Garvey. Los hombres ensayaban himnos y se enrolaban en una milicia organizada por los legionarios que acompañarían a Garvey. La prensa nacional, que daba cuenta de los pormenores de su visita, publicó:

M. Garvey líder de la raza negra. Ha sido nuestro huésped durante varios días el señor Marcus Garvey, quien de paso para los Estados Unidos decidió visitar San José. La United Fruit Company, al tener conocimiento, le ofreció un tren especial que lo condujo a la capital (Diario de Costa Rica, 17 de abril de 1921).

Durante la estadía de M. Garvey se desarrolló una gran campaña en la venta de acciones. Parte de la propaganda decía así: A progressive program for Negro Factories Corporation Dear sir or madam. "Compre sus acciones y contribuya a abrir y operar fábricas en los grandes centros industriales de Estados Unidos, Centroamérica, Indias Occidentales y África. Negro Factories Corporation anuncia la puesta en venta de 200 mil dólares en acciones" (Ross, 2000, p. 194).

Treinta y cinco mil dólares. El señor M. Garvey, presidente de la Universal Negro Improvement (UNIA), llevó con él la respetable suma de treinta y cinco mil dólares, recogida en el espacio de tres días que estuvo en Puerto Limón. Ese es el rumor público. (La Tribuna, 26 de abril de 1921). 
En 1922, se abrió en la ciudad de Limón el primer Liberty Halls bajo la dirección de Roberts y Charles Bryant. Más adelante se abrieron filiales en Siquirres, Matina, Madre de Dios, Cahuita y Puerto Viejo. Solo en Costa Rica, y de manera general en el litoral caribeño del país, llegaron a funcionar 21 filiales, testimonio del gran impacto de las ideas de Garvey. Es indudable que el discurso de Garvey unió a la población en torno a sus raíces africanas y a la posibilidad de construir un proyecto propio, marcando con ello un elemento importante en la construcción identitaria. Los limonenses recuerdan que en la década de 1920 todo Limón se paralizó, reuniéndose 18.000 personas a escuchar a Garvey en un acto público. ${ }^{133}$

No solo Limón, sino todo el Caribe, incluyendo los países de habla hispana y francesa, se vieron influenciados por estos planteamientos sin precedentes en la historia de los movimientos sociales del continente.

\section{La UNIA en República Dominicana}

Los braceros que migraron desde el Caribe inglés a la República Dominicana a trabajar en los ingenios azucareros se distinguieron por tener diversas organizaciones, las cuales les ayudaban a mantener su identidad. Se aglutinaban en iglesias protestantes, escuelas en inglés, logias de socorro mutuo, instituciones deportivas, de danza, y en su momento la muy particular Asociación Universal por el Mejoramiento del Negro y Comunidades Africanas (UNIA-ACL, por sus siglas en inglés), conocida también como Black Star Line, Inc., que los dominicanos por una corruptela llamaban en español La Blatalán.

En la República Dominicana se conformaron cinco capítulos de la UNIA. Los mismos operaban en diferentes centrales azucareros (Rosario, 2015, p. 139). Algunos autores han llegado a señalar que el acontecimiento más importante que se registró en la comunidad cocola fue "la creación en 1919, del capítulo 26 de la UNIA-ACL en San Pedro de Macorís" (García y Giovannetti, 2003, p. 153). Dicha acción estuvo a cargo del reverendo Philips Van Putten, bajo el Gobierno de ocupación norteamericana. Las acciones de la UNIA pronto se extendieron a otras provincias

133. En diferentes periódicos de la época se publicaron varias fotografías del acto. En la revista Limón Roots, edición n. 1, año 1, 1999, se reproduce una foto panorámica de una actividad de la UNIA que se celebró en 1926, en Plaza Iglesias, Ciudad de Limón (hoy es el estadio Juan Gobán). 
como Sánchez y Santo Domingo (Inoa, 2005, p. 102). En menos de un año, "La Blatalán" tenía inscritos unos dos mil miembros.

El 31 de agosto de 1921, la UNIA organizó una marcha de los seguidores de M. Garvey para conmemorar el aniversario de la organización. Al pasar frente a la casa del reverendo Beer, representante de la Iglesia episcopal y vicecónsul inglés, los que encabezaban el desfile arrojaron banderas inglesas al suelo, las pisotearon y escupieron en un acto de repudio al dominio inglés. El sábado 3 de septiembre, por instigación del reverendo Beer, los marines norteamericanos asaltaron el local de la organización y encarcelaron al reverendo Philips y a otros 14 dirigentes. La organización fue declarada ilegal y el reverendo Philips y otros líderes del movimiento fueron expulsados del país (Inoa, 2005, p. 104).

Las acciones de las autoridades militares fueron tomadas como una represión racista. Además de la UNIA, la persecución también llegó a la African Blood Brotherhood (Hermandad de la Sangre Africana). Esta organización era de tendencias bolchevique y anarquista y funcionaba en Macorís desde 1919, y con frecuencia se confundía con la UNIA. García y Giovannetti (2005) sostienen que la represión pudo "haber sido causada principalmente por tres razones vinculadas entre sí: el racismo; la disputa entre las iglesias blancas y negras; y la ideología de la organización" (p. 142). Con frecuencia se registraban conflictos entre las Iglesias protestantes cuando los miembros afrodescendientes creaban sus propias Iglesias para no recibir el trato racista de los pastores blancos. En ocasiones, los pastores negros eran al mismo tiempo dirigentes de la UNIA. El estudio de García y Giovannetti, citando a Harpelle (2001), refiere cómo "en 1910, el mismo Garvey fue protagonista de un conflicto entre Iglesias durante su estadía en Puerto Limón, Costa Rica, con la diferencia de que fue con las clases más altas de la sociedad afroantillana" (pp. 32-33).

Ante los atropellos cometidos contra los miembros de la UNIA de San Pedro de Macorís, la UNIA de Nueva York envió a De Bourg en calidad de comisionado para gestionar la libertad de los encarcelados. Pero ante la negativa de las autoridades, De Bourg le escribió a Winston Churchi1l, quien a la sazón se desempeñaba como secretario de Estado para las Colonias del Reino Unido, solicitando una investigación sobre el papel de los cónsules británicos que no les daban protección a los súbditos británicos negros. Y de manera expresa denunciaba la actitud del reverendo 
Beer, "ninguna calamidad mayor puede ocurrirle al mundo, que una mayor acentuación de las divisiones en cuestiones de raza", decía De Bourg a Churchill (García, 2003, p. 147).

Los arrestos a los miembros de la UNIA en San Pedro de Macorís realizados por el Gobierno de ocupación norteamericano se convirtieron en conflicto candente. El propio Marcus Garvey, en un discurso pronunciado en Nueva York, manifestó que se trataba de una controversia por:

la creación de una nueva iglesia y que las otras iglesias [...] estaban luchando contra su organización porque les estaban llevando sus miembros con el pretexto de que sus miembros se estaban uniendo a la UNlAACL [...] los Liberty Halls no serían utilizados como iglesias y que nosotros no nos organizamos como ninguna iglesia y $[. .$.$] no tenemos víncu-$ los con el bolchevismo y el socialismo, ni con ninguna iglesia, y por eso había enviado a De Bourg a un costo de cientos de dólares para arreglar la situación. (García y Giovannetti, 2005, p. 168).

Los miembros de la organización se mostraron complacidos al ver a su líder ocupándose de sus asuntos.

De Bourg, el enviado de la UNIA, debió prolongar su estadía en la República Dominicana hasta tanto se resolvieran las situaciones. En un momento dado, De Bourg participó en una reunión multitudinaria de la UNIA y el cónsul y reverendo Beer lo acusó de violar la orden de no celebrar reuniones e incitar a la oposición y a la resistencia contra el Gobierno militar. De Bourg fue apresado por las tropas norteamericanas de ocupación, juzgado y condenado al pago de una multa de trecientos pesos. Pero de nuevo De Bourg acudió a los contactos internacionales de la UNIA. Finalmente tuvo que ser absuelto. Incluso se le devolvió el dinero de la multa. La acción fue celebrada como "un triunfo supremo". En una especie de desagravio, asistieron a una reunión de la UNIA, el más alto funcionario del Gobierno militar, el gobernador de la provincia y un representante del ayuntamiento. La suspensión de la UNIA fue levantada.

Nadal Walcot, cocolo de segunda generación nacido y criado en el ingenio Consuelo de San Pedro de Macorís, recuerda que "durante un tiempo bastante prolongado, los cocolos de edad avanzada llevaban en sus bolsillos un escrito de Marcus Garvey titulado Up, you mighty race 
(Walcot, 1998, p. 14). Esto demuestra la influencia del movimiento y la fidelidad de la comunidad. La filial 26 sobrevivió por años a todas las demás. Algunos de los miembros de San Pedro de Macorís se volvieron legendarios, como fue el caso de Carlos Cook. Este petromacorisano se fue a vivir a Nueva York en 1929, específicamente a Harlem. Este hombre, nacido en San Pedro de Macorís, se convirtió en un activista de la UNIA en Estados Unidos. Cuando la organización entró en decaimiento, según narra Inoa (2018), "en ausencia de Garvey, en el 1938, [Cook] asumió la dirección de la UNIA, lo que se extendió hasta la muerte de Garvey en junio de 1940, cuando el movimiento se fraccionó" (p. 122).

La muerte de Garvey en 1940, ocurrida en Londres, fue un duro golpe. Como la UNIA estaba fraccionada, fue languideciendo hasta desaparecer. Pero, ni la muerte de Garvey ni el cierre de la UNIA apagó la esperanza que encendió el garveyismo en los afroamericanos. La muestra de ello es que luego resurgieron variados movimientos de reivindicación para los negros como fueron: La Negritud (con Aimée Cesaire), la African Nacionalist Pioners Movement (fundada por Carlos Cook), las Panteras Negras, los rastafaris, entre otros.

\section{Comentarios finales}

1. Tanto en Costa Rica como en República Dominicana, a finales del siglo XIX, la llegada de los inmigrantes caribeños británicos estuvo asociada a la penetración del capital norteamericano. Los campesinos, en su mayoría pequeños propietarios, no se motivaron a trabajar en los enclaves bananeros y centrales azucareros por sus bajos salarios. Por igual, en ambos países, las transnacionales norteamericanas impusieron a los inmigrantes caribeños británicos como la mano de obra idónea en las primeras décadas. En la década del 20, los norteamericanos en República Dominicana propiciaron el cambio de los antillanos británicos por los haitianos y en Costa Rica, en la década del 30, se trasladaron del Caribe al Pacífico, donde las leyes impedían la contratación de afrodescendientes, con lo que se les sometía a segregación territorial.

2. Desde la segunda mitad del siglo XIX, en los dos países se hicieron ingentes esfuerzos por atraer inmigrantes caucásicos. Pero la inmigración que ambos recibieron fue, precisamente, la que los dueños del capital 
impusieron, que fueron aquellos que sus leyes vigentes, con criterios racistas, rechazaban.

3. Tanto en un país como en el otro los inmigrantes fueron impactados por el movimiento garveyista y en ambos crearon capítulos de la UNIA. En estos dos países, por la barrera del idioma y los prejuicios raciales, la población hispana no asumió la lucha de la UNIA; esto no ocurrió ni siquiera en Santo Domingo, donde un alto porcentaje de su población es mulata y negra.

4. En ambos países los inmigrantes lograron mantener y redefinir su identidad basándose en el trípode de familia-iglesia-escuela, complementándose con logias y sociedades de ayuda mutua. En los dos países es significativo y diverso el legado cultural de estas inmigraciones a la cultura nacional, destacándose en estos la música y el baile.

El día en que completaba el primer borrador del presente estudio, el sector cultural dominicano, incluyendo su diáspora en Estados Unidos, fue impactado por la muerte del gran poeta cocolo Norberto James. Las redes sociales hicieron viral la triste noticia. Las almas dominicanas que lo conocían, a su modo, lloraron por este poeta nacido en el ingenio Consuelo, de San Pedro de Macorís, hijo de inmigrantes cocolos que vinieron a trabajar en las plantaciones azucareras dominicanas. Solo un poeta de su estirpe pudo recoger en el poema Los inmigrantes el desarraigo de la comunidad cocola en Santo Domingo. Intuí en ese momento que el poeta me pedía que lo invitara a cerrar este trabajo con esa pieza. La incluyo en homenaje a su memoria. También incluyo el poema $A$ mi primo jamaiquino, de Eulalia Bernal, costarricense de origen jamaiquino, poeta, luchadora infatigable por hacer visibles a todos aquellos que, como dice el poeta James, "No tuvieron tiempo de decir: / Esta tierra es nuestra".

\section{Los inmigrantes}

(fragmento)

Norberto James, dominicano

Aún no se ha escrito

la historia de su congoja.

Su viejo dolor unido al nuestro.

No tuvieron tiempo

de niños para asir entre sus dedos 
los múltiples colores de las mariposas.

Atar en la mirada los paisajes del archipiélago.

Conocer el canto húmedo de los ríos.

No tuvieron tiempo de decir:

Esta tierra es nuestra.

Juntaremos colores.

Haremos bandera.

La defenderemos.

San Pedro de Macorís, 1969

\section{"Requiem a mi primo jamaiquino"}

Eulalia Bernard, costarricense

Lo protegió la muerte

contra tanta infamia

Y el misterio de su suerte.

Sin saber por qué,

Nunca el Himno Nacional,

llegó a cantar

con la mano en la frente.

Su sudor germinó

Un pedacito de esa tierra

inhóspita y fértil del trópico,

que no será nunca tierra patria

pues cedularse jamás pudo

mi primo jamaiquino.

Rodeos y más rodeos tuvo

de blancos papeles de blancas manos

para decir simplemente:

Soy negro del campo,

del Valle La Estrella.

Soy una estrella negra

en el flamante blanco, azul y rojo

de nuestra bandera.

Costa Rica, 1996 
Migraciones caribeñas de las colonias inglesas hacia Costa Rica y República

Dominicana: procesos raciales y el impacto de las ideas de Garvey (1872-1950)

\section{Referencias}

Acuña, V. (2001, 8 de abril). Mito de la nación costarricense. Áncora. Recuperado de http://historiacomprometida.blogspot.com/2008/11/mito-de-la-la-nacin-costarricense-vctor.html

Alvarenga Venutulo, P. (2005). La inmigración extranjera y la nación costarricense. En Encuentro Internacional Poblaciones Migrantes y Derechos Humanos en América Latina. Heredia: UNA. Costa Rica.

Álvarez, F., et al. (2000). Presencia étnica en San Pedro de Macorís. Santo Domingo: Editora de Colores.

Boza Villareal, A. (2004). Indígenas, comerciantes transnacionales y Estados. Población, comercio y política entre las poblaciones indígenas de la Gran Talamanca. Costa Rica (1840-1930). (Chiripó, Estrella, Talamanca y Pacífico Sur (tesis de maestría, Universidad de Costa Rica, San Juan, Costa Rica). Recuperado de https://kerwa.ucr.ac.cr/bitstream/handle/10669/79766/ Boza_TesisMaestria_2004.pdf? sequence=2\&isAllowed $=\mathrm{y}$

Bryan, P. (1973). En torno a la recepción de los cocolos en República Dominicana. Santo Domingo: Universidad Autónoma de Santo Domingo.

Capdevila, L. (2004). Una discriminación organizada: leyes de inmigración dominicanas y la cuestión haitiana en el siglo XX. Tebeto, Anuario del Archivo Histórico Insular de Fuerteventura, núm. Extra-5, 438-454.

Cassá, R. (2020). Movimientos y memoria. Santo Domingo: SERD-NET; SRL.

Casey Gaspar, J. (1979). Limón 1880-1940. Un estudio de la industria bananera en Costa Rica. San José: Editorial San José.

Congreso Nacional (1927). Colección de Leyes, Decretos y Resoluciones emanadas de los poderes legislativo y ejecutivo de la República Dominicana Dominicana (t. 2) Santo Domingo: Imprenta del Listín Diario.

Congreso Nacional (1928). Colección de Leyes, Decretos y Resoluciones emanados de los poderes Legislativo y Ejecutivo de la República Dominicana, tomo sexto. Santo Domingo: Imprenta del Listín Diario.

Congreso Nacional (1929). Colección de Leyes, Decretos y Resoluciones emanados de los poderes Legislativo y Ejecutivo de la República Dominicana (t. 7) Santo Domingo: Imprenta del Listín Diario.

Cuello, J. (1997). Contratación de mano de obra haitiana destinada a la industria azucarera dominicana, 1952-1986. Santo Domingo: Editora Taller.

Fonseca, E. (2001). Centroamérica: su historia. San José: EDUCA. 
Franco Pichardo, F. (1996). Historia económica y financiera de la República Dominicana, 1844-1962. Santo Domingo: Editora de la UASD.

Franco Pichardo, F. (2008). Historia del pueblo dominicano. Santo Domingo: Editora Mediabyte.

García Muñiz, H. (2005). La plantación que no se repite: las historias azucareras de la República Dominicana y Puerto Rico 1870-1930. Revista de Indias, 65(233), 173-192.

García Muñiz, H., y Giovannetti, J. (2003). Garveyismo y racismo en el Caribe: el caso de la población cocola en la República Dominicana. Estudios del Caribe, 31(1), 139-211.

Garvey, M. El enemigo más grande del hombre. El Mundo Negro (EABIC. Serie de Héroes Africanos, vol. 2). Recuperado de https://issuu.com/elmundonegro/ docs/binder 1

García González A. y Álvarez, R. (1999). En busca de la raza perfecta. Eugenesia e higiene en Cuba, 1898-1958. Madrid: CSIC.

Guerrero, J. (2020). Caribes y taínos: dos etnias aliadas y enemigas. Revista ECOS UASD, 27(19), 63-108.

Harpelle, R. (2001). The West Indians of Costa Rica: Rase, Class, and the Integrations of and Ethnic Minority 1957. Kingstown: McGraw Hill; Quee’s University Press.

Hopenhayn, M., y Bello, Á. (2001). Discriminación étnico-racial y xenofobia en América Latina y el Caribe (Políticas Sociales, serie 47). Santiago de Chile: CEPAL.

Inoa, O. (2005). Los Cocolos en la sociedad dominicana. Santo Domingo: Helvetas.

Inoa, O. (2018). Trabajadores inmigrantes en la República Dominicana. Santo Domingo: Editora Letra Gráfica.

Jarvis Luis, R. (2019). Inmigrantes de las Antillas británicas en la República Dominicana. Cocolos en San Pedro de Macorís y La Romana: 1870-1950 (tesis de doctorado, Universidad Pablo de Olavide, Sevilla, España). Recuperado de https:/dialnet.unirioja.es/servlet/ tesis? codigo $=263979$ \&orden $=0$ \&info $=$ link.

Majfud, J. (2019-2). El racismo no necesita racistas. Correo de la UNESCO, (2), 45-47.

Marek, J. (2004). Cuatro pensadores anticoloniales del Caribe anglófono del siglo XX: Garvey, James, Williams y Rodney. Cuadernos Americanos, Nueva Época, 3(105), 157-167.

Meléndez, C. y Duncan, Q. (1972). El negro en Costa Rica. San José: Editorial Costa Rica. 
Migraciones caribeñas de las colonias inglesas hacia Costa Rica y República

Dominicana: procesos raciales y el impacto de las ideas de Garvey (1872-1950)

Miranda, M. y Vallejo, G. (2005). Darwinismo social y eugenesia en el mundo latino. Buenos Aires: Siglo XXI Editores.

Mota Acosta, J. C. (1977). Los cocolos en Santo Domingo. Santo Domingo: Editorial La Gaviota.

Moya Pons, F. (2008). Historia del Caribe. Santo Domingo: Editora Búho.

Nadal Walcot, A. (1998). Los Cocolos de Nadal Walcot. Santo Domingo: Editorial Alfa y Omega.

Putnam, L. (2012). Foráneos al fin, La saga multigeneracional de los antillanos británicos en América Central, 1870-1940. En L. Gudmundson y J. Wolfe (ed.), La negritud en Centroamérica. Entre raza y raíces (pp. 367-403). San José: EUNEDM..

Romero Contreras, R. (2012). La Cultura Rastafari y sus principales manifestaciones identitarias. Pacarina del Sur, 3(10).

Rosario, R. (1989). Algunos aspectos etnodemográficos de la inmigración haitiana hacia la República Dominicana (tesis de maestría no publicada). Universidad de Lomonosov, Moscú, Rusia.

Rosario, R. (2007). La inmigración haitiana y la identidad dominicana. En A. Santana (coord.), Retos de la migración latinoamericana (pp. 99-116). México: Universidad Autónoma de México.

Rosario, R. (2015). Identidades de la población de origen jamaiquino en el Caribe Costarricense (segunda mitad del siglo XX). Santo Domingo: Editora Búho.

Rosental, M., y Ludin, P. (1981). Diccionario filosófico. La Habana: Editora Política. Ross, Y. (2000). La flota negra. México: Editora Alfaguara.

Sang Ben, M. (2020). Volviendo al Caribe. Santa Marta: Editorial Unimagdalena. Soto Quirós, R. (1998). Inmigración e identidad nacional 1904-1042. Los otros reafirman en nosotros (tesis de doctorado no publicada). Universidad de Costa Rica, San José, Costa Rica.

Soto Quirós, R. (2005). Discursos y políticas de inmigración en Costa Rica: 1862-1943. Revista Iberoamericana, 5(19), 119-133.

Soto Quirós, R. (2006). Un otro significante en la identidad nacional costarricense: el caso del inmigrante afrocaribeño, 1872-1926. Boletín, (25), 1-32.

Stanley, A. (2017). Tiempo muerto (19.a ed.). Santo Domingo: Cocolo Editorial. Stewart, W. (1991). Keith y Costa Rica. San José: Editorial San José.

Veeser, C. (2019). El protectorado de Estados Unidos. En F. Franco. Historia General del Pueblo Dominicano (t. 4, pp. 207-234) Santo Domingo: Editora Búho. 


\section{Infraestructura ferroviaria y migración en Panamá, siglos XIX y XX}

Juan Santiago Correa Restrepo

Colegio de Estudios Superiores de Administración (CESA)

\section{Introducción}

El presente estudio se propone demostrar cómo los fenómenos migratorios que acompañaron estos desarrollos de infraestructura han sido estudiados en diferentes momentos, por diferentes autores y con objetivos diversos. Tales indagaciones arrojan luz sobre un proceso de movilidad poblacional complejo, pero también dejan preguntas sin resolver en áreas que lo reclaman. Se evidencian, empero, tendencias de investigación, temáticas en auge, consensos entre académicos, jerarquías y clasificación de temas y problemáticas a la espera de ser examinadas.

A fin de lograr nuestro objetivo, revisaremos algunos trabajos relevantes en los últimos cincuenta años para mostrar los intereses investigativos y los objetivos, abordajes y resultados de tales indagaciones. La línea que conecta a los distintos autores y trabajos es la migración hacia Panamá debido a la construcción del Ferrocarril de Panamá, el Canal francés y el Canal norteamericano. Algunas temáticas son recurrentes y otras, estudiadas de modo excepcional, por lo cual algunas investigaciones presentan mayores consensos y desarrollos que otras. De hecho, muchos de tales trabajos pudieron ser realizados con fuentes similares y con los trabajos de sus pares académicos como referencia. 
Una cronología de dichas investigaciones, aparte de ser tarea laboriosa, puede conducir a equívocos o a resultados obvios o carentes de interés. Por tanto, los trabajos examinados se clasificarán en dos grandes bloques orientados por la pregnancia del proceso migratorio y la temática principal trabajada. El primero, conformado por trabajos no directamente relacionados con lo migratorio, pero que lo abordan en algún sentido, bloque a su vez dividido en dos: el primero, conformado por trabajos relacionados con los procesos de construcción de infraestructura; y el segundo, por trabajos sobre la población que vivió en esta zona de Panamá. El segundo bloque de interés son los trabajos sobre la presencia antillana en el istmo, abordada en diferentes momentos y por diferentes estudiosos.

\section{Migración como temática subordinada en la historiografía general}

\section{Trabajos sobre los procesos de construcción de infraestructura}

Aunque abundan los estudios sobre la construcción del canal de Panamá desde diversas ópticas y en momentos distintos, la mayoría de tales estudios ignoran lo migratorio o apenas lo mencionan o lo reducen a resumen estadístico. Para comenzar, en The path between the seas: the creation of the Panama Canal, 1870-1914, McCullough (1977) se centra en la bibliografía hasta 1914 y en las fuentes primarias que le son útiles para tratar sobre dicha construcción. Puesto que el autor enfoca su interés en el proyecto canalero, la problemática migratoria queda reducida a datos estadísticos como la procedencia (EE. UU., China, Antillas, España) y el número de migrantes que llegaron como fuerza laboral a las obras del canal, si bien ensaya algunas explicaciones para dicho movimiento poblacional y describe en qué condiciones se desempeñan estos obreros. Como norma, este enfoque estará presente en el primer grupo de trabajos analizado en este estudio.

En su indagación acerca de la sociedad panameña del siglo XIX, Dominio y sociedad en el Panamá colombiano (1821-1903), Figueroa (1978) aborda la construcción del ferrocarril y del canal francés. Para ello, revisa la historia de Panamá desde cuando pertenecía a Colombia a partir de una exhaustiva historiografía en la que, de nuevo, datos estadísticos le permiten ver el impacto de la migración en el istmo. Es notable la referencia de cifras obtenidas de otros autores y la hipótesis de que la ola migratoria obedeció a la necesidad de mano de obra para tareas obreras 
en la Panamá del siglo diecinueve. En Hombres y ecología en Panamá, Jaen (1981) dedica una importante sección de su obra a las adaptaciones al ambiente natural del istmo y las estrategias que lo permitieron. En una primera fase indica las fuentes estadísticas que permiten establecer tendencias para comprender la adaptación en tiempos de construcción del canal francés, el canal norteamericano y parte del siglo XX. Enseguida se centra en los antecedentes para contextualizar las enfermedades tropicales, las tasas de mortalidad y las dinámicas geográficas y demográficas desde el período colonial hasta mediados del siglo XIX, todo ello para centrarse en la mortalidad durante la ejecución de los proyectos francés y norteamericano. En La tierra dividida: historia del Canal de Panamá y otros proyectos del canal ístmico, Mack (1992) sigue la ruta de $\mathrm{McCu}$ llough, trata sobre los diferentes proyectos que tuvieron lugar en la zona del canal, pero deja en segundo plano el fenómeno migratorio. No obstante, y desde un juicioso trabajo historiográfico, ilustra los problemas presentados en las etapas iniciales de la construcción por la falta de mano de obra nativa y los problemas para reclutar y mantener durante largos períodos a obreros que migraban hacia el proyecto canalero. Es de destacar el interés en las condiciones cotidianas que tenían los obreros migrantes y aspectos derivados de estas como los salarios y las tasas de mortalidad, a los que accede con diferentes tipos de fuentes. En In the path of empire: labor, land and liberty in Panama during the California gold rush, 1848-1860, McGuinness (2001) examina la construcción del ferrocarril y su impacto en aspectos de la sociedad panameña inmediata a la obra. Al tratar el problema de la mano de obra, señala que el proyecto fue dinamizado por la fiebre del oro y la consecuente migración hacia el oeste de EE. UU. y que se tuvieron grandes problemas para mantener a los obreros por el gran número de decesos, el poco interés en mantenerse en esta zona y la desobediencia de algunos migrantes. En Aquellos tiempos de California: el ferrocarril de Panamá y la transformación de la zona de tránsito durante la fiebre del oro (McGuinness, 2004), son notables las similitudes con la tesis antes mencionada. En Panamá durante la época de construcción del canal norteamericano, Conniff (2004) revisa la historiografía señalando hitos del fenómeno canalero al comenzar los años 1900. Nuevamente la migración en el istmo es asunto de segundo nivel, aunque visibiliza el racismo y exclusión que para la época padece la población migrante. Según 
el autor, la discriminación racial en EE. UU. se traslada al istmo durante la construcción del canal, si bien europeos y norteamericanos llegados a la zona son vistos como ejemplo de modernidad. También repara en los problemas ambientales causados por la construcción del canal, como el despoblamiento de aldeas que debieron ser inundadas para la represa del lago Gatún, hecho que también generó migración interna.

Dos trabajos de la historiografía colombiana, Inversión extranjera directa y construcción de ferrocarriles en Colombia: el caso del ferrocarril de Panamá (1849-1869) (Correa, 2010) y The Panamá Railroad Company o cómo Colombia perdió una Nación (Correa, 2012), tratan diversos aspectos de la historia panameña durante la construcción y funcionamiento de la línea férrea. En el primer trabajo, el autor examina las ideas para una ruta que conectara el océano Atlántico y el Pacífico a través de Panamá y el rol que en este proceso tuvo la inversión extranjera. El segundo trabajo es una continuación del anterior, aunque va más allá y estudia la influencia del interés extranjero y local en la independencia de Panamá y los efectos de estos sobre el ferrocarril y el canal interoceánico. Aunque estos estudios no se centran en lo migratorio, sí dedican espacio para abordar el fenómeno desde la recopilación de trabajos académicos.

\section{Trabajos sobre migrantes en la zona canalera}

Como ya se dijo, hay un segundo grupo de investigaciones sobre la población que vivió en esta zona de Panamá, trabajos enfocados en fenómenos poblacionales o demográficos, pero donde lo migratorio tampoco es protagonista, acaso una pequeña parte de los trabajos o solo una de las muchas aristas que conforman un tema más amplio. Así, en La población del istmo de Panamá del siglo XVI al siglo XX: estudio sobre la población $y$ los modos de organización de las economías, las sociedades y los espacios geográficos, Jaén (1979) presenta estadísticas de fuentes primarias y secundarias sobre la migración entre 1880 y 1920, centrándose en las dinámicas poblacionales y aspectos relativos a esta en el istmo desde el período colonial. Menciona el arribo de múltiples grupos poblacionales y explica las razones que propiciaron esta movilización. Ilustra, además, las condiciones de la llegada y asentamiento de poblaciones migrantes, apartado en que aborda el entorno sanitario, racial, discriminatorio y de 
alta mortalidad en que viven quienes aceptan enrolarse en los diferentes proyectos para la construcción del canal, aspectos que convierten este trabajo en referente obligado para los investigadores que en adelante abordan lo migratorio. En la compilación El movimiento obrero en $\mathrm{Pa}$ namá (1880-1914), Navas (1999) aborda desde diferentes perspectivas la lucha obrera desde el inicio del canal francés hasta bien entrados los años del siglo veinte. Navas se basa en una revisión de fuentes primarias y un gran componente de bibliografía sobre diferentes temas que le permiten extraer elementos para caracterizar la realidad del obrero a finales del siglo XIX y principios del XX. Aunque lo migratorio no es el eje del trabajo, es abordado como determinante de las condiciones vividas en el istmo durante el período examinado. Al analizar la población migrante, encuentra tres grupos: migrantes con contratos desde las zonas antillanas, migrantes espontáneos que se emplearon una vez en Panamá y población norteamericana escasa debido a los bajos salarios y lo poco atractivo del proyecto para esta población. El autor examina, por último, las precarias condiciones de los migrantes en el proyecto canalero y las relaciones de la compañía con otras como la United Fruit Company para enviar trabajadores ante el exceso de mano de obra dado en algunos momentos. En El trabajo de las mujeres en la historia de la construcción del canal de Panamá, Reyes (2000) intenta resarcir el olvido de la participación de la mujer como sujeto histórico. Es un abordaje desde la perspectiva de género, que explica el rol de la mujer como una consecuencia de lo migratorio y de la vida de quienes participaron en las obras del canal. La autora describe Panamá como una "zona de frontera", adonde arriban poblaciones que se transforman en grupos flotantes y se terminan estableciendo a lo largo de la zona del canal mientras este se construye. Argumenta, además, cómo las políticas de la compañía fueron discriminatorias e incluso "fascistas", no solo en términos de "raza", sino de sexo, lo que se combinaba con condiciones de insalubridad y violencia aun en los espacios privados como la familia. Mientras las mujeres norteamericanas se empleaban como maestras y administradoras, discriminadas en lo salarial, las no blancas eran doblemente segregadas y ocupaban trabajos como lavanderas, prostitutas, cocineras o vendedoras. Reyes concluye que el trabajo de la mujer en la construcción del canal de Panamá fue muy valioso, pero poco valorado y estudiado. 
En La inmigración internacional en el Caribe panameño vista a través de los censos, Marín (2009) evidencia el interés de la demografía en el fenómeno poblacional y los cambios que sufrió el istmo a principios del siglo XX. Aunque el interés central de Marín no es lo migratorio, expone elementos para entender la evolución de la población migrante y el comportamiento de crecimiento demográfico en las etapas posteriores a la culminación de las obras. Completando a Reyes (2000), la autora admite las rupturas que pudo tener la estructura familiar, pero revela cómo muchos migrantes llegados o establecidos en Panamá lo hicieron con sus familias. Señala también que, finalizadas las obras, la población concentrada en Colón y en Panamá se distribuyó heterogéneamente hacia otros sectores productivos ajenos a la zona norteamericana. Las migraciones laborales en las islas del Caribe, de Johnson (2011), es el único trabajo cuyo objeto específico es lo migratorio, aunque señalando que no fue un fenómeno exclusivo del ferrocarril de Panamá y de la posterior zona del canal. Por el contrario, muestra cómo las migraciones en las Antillas eran un hecho constante. De los casos estudiados, el jamaiquino es el principal, donde la autora ve como causa de la migración saliente el crecimiento poblacional en la isla y el subsiguiente desempleo generado por la incapacidad de emplear toda la población en tareas productivas. Esta pobreza generalizada creó las condiciones para que la población saliera en busca de empleo, por lo que las diásporas antillanas en EE. UU. y países de Centroamérica no regresarán jamás.

\section{Trabajos sobre poblaciones migrantes específicas en el istmo de Panamá}

Son escasos los trabajos académicos sobre migración de grupos poblacionales específicos. Hemos visto cómo el objeto recurrente es la construcción de infraestructura - construcción del Ferrocarril de Panamá, del Canal francés y del Canal norteamericano-, junto a lo cual lo migratorio es elidido, escasamente analizado o reducido a estadísticas para explicar otras dinámicas de mayor interés para los investigadores de las disciplinas sociales. En materia de poblaciones específicas, los análisis pueden rastrearse hasta las décadas de 1970 y 1980, si bien para algunos autores este campo de estudio es insoslayable desde la década de 1950. 
Para el caso antillano, en Los hombres del 'Silver Roll': migración antillana a Panamá, Newton (1984; en español, 1995) presenta el estudio específico más completo sobre el fenómeno migratorio de antillanos a Panamá en la segunda mitad del siglo dicienueve y primeros del siglo veinte, debido a la rigurosa búsqueda de bibliografía, hemerografía, estadísticas y documentos históricos como contratos y avisos de reclutamiento, entre otros. Newton aborda aspectos como las causas de la migración hacia el istmo desde las diferentes islas del Caribe, entre ellas la crisis interna que estas vivían y la necesidad de muchos de sus habitantes de emigrar en busca de empleo y mejores salarios. Afirma que, el crecimiento poblacional desbordaba la empleabilidad en las islas y que al enterarse de los proyectos panameños, esta población salió masivamente en busca de empleo. A esta primera ola respondieron en gran número los jamaiquinos, quienes fueron el mayor grupo poblacional en la construcción del ferrocarril y del Canal francés. Según Newton, este primer período, denominado de controles mínimos, se caracteriza por el fácil reclutamiento y el arribo masivo de obreros desde las Antillas, lo que, tras el fracaso de la compañía francesa, se tradujo en el abandono de población, principalmente jamaiquina, que quedó varada en Panamá. La autora describe cómo para la segunda ola hubo mayor control y choques entre los Gobiernos antillanos y la compañía del canal, dado el temor de que se repitiera el abandono que se había producido con la compañía francesa. Dicho descontento se evidencia en el caso de Jamaica que, para la construcción del Canal norteamericano, tiene una muy pequeña proporción de jamaiquinos entre los obreros.

El autor, además, hace un uso intensivo de las estadísticas que le permiten explicar la dimensión del fenómeno migratorio hacia Panamá durante más de medio siglo. Gracias a esto, elabora un perfil del migrante y explora múltiples escenarios en que se daban las migraciones y cómo estas impactaban también los lugares de origen de los migrantes. Finalmente, examina a fondo la cotidianidad del obrero antillano en el istmo, con énfasis en las estrategias de reclutamiento, los salarios, las condiciones sanitarias y de vivienda, las tasas de mortalidad y las condiciones de trabajo.

Con la conmemoración de la separación de Colombia, entre finales del siglo XX y comienzos del XXI aparece un copioso número de estudios sobre la historia de Panamá y algunos temas coyunturales como la 
construcción del canal y el impacto de la población migrante. En Los inmigrantes antillanos en Panamá, Westerman (1999) propone un estudio histórico sobre los procesos migratorios de esta población en el área del canal. Mediante cifras, argumenta que el reclutamiento fue más exitoso en algunos casos que en otros, toda vez que la cantidad de migrantes entrantes es mayor para casos como el de Barbados. Junto a esto, señala que la discriminación racial abarcó múltiples esferas. En una fase inicial, la estudia desde las estadísticas salariales y la creación de las nóminas diferenciadas (Golden Roll y Silver Roll), pero también desde los dispositivos sanitarios y educativos que en la cotidianidad separan a los negros de los blancos. En una segunda fase, examina la repatriación posterior a la finalización de las obras, indicando que debido al exceso de mano de obra, se recrudece el problema del desempleo, más aun si se considera que muchos antillanos se negaron a regresar a sus hogares y buscaban la manera de volver cuando eran repatriados. Por último, Westerman recorre las reivindicaciones a esta población en las que se la reconoce como constructora de la obra y el rechazo a la discriminación por cuestiones de raza u origen.

En El canal de Panamá y los trabajadores antillanos. Panamá 1920: cronología de una lucha, Maloney (1999) estudia la población antillana en las etapas inmediatamente posteriores a la terminación del canal. Aunque la investigación no se centra en lo migratorio, sino en los movimientos obreros de las décadas 1910 y 1920, hace una estupenda contextualización de las causas de la presencia de un nutrido número de antillanos a comienzos del siglo XX. Según Maloney, el racismo es un problema estructural con expresión harto dramática durante la construcción del canal. Aparte del racismo manifiesto de diversos modos en la vida cotidiana, los antillanos sufrieron las inclemencias del trabajo y altas tasas de mortalidad por razones sanitarias y de realización de trabajos peligrosos. En suma, para el autor, las condiciones vividas por los migrantes antillanos serán la causa de las huelgas de 1916 y 1920.

$\mathrm{Al}$ ser uno de los mayores conocedores de la presencia de antillanos en Panamá, en el contexto de la publicación de la Historia General de Panamá, con motivo del centenario, publica en esta compilación un capítulo titulado "Significado de la presencia y contribución del afropanameño en la nación panameña”, en el que Maloney (2004) analiza con riqueza de detalles el 
fenómeno del acoplamiento y adaptación de esta población migrante a la sociedad panameña en período posterior a la construcción del canal.

Aunque no es un trabajo sobre el fenómeno migratorio, encuentra en la movilidad poblacional del siglo XIX y primeros años del XX un gran cambio en la demografía panameña que tendría impacto a largo plazo. Exalta el componente racial y el racismo al que fueron sometidos incluso después de finalizadas las obras y que se materializó de múltiples maneras y para el cual se tomaron en cuenta elementos como la lengua, el nombre y la religión. Con relación a las mujeres, aspecto poco examinado, como hemos visto, propone que estas arribaron al istmo como una estrategia para aumentar la productividad mediante matrimonios, en un entorno en que los empleos más difíciles y menos pagos eran realizados por esta población.

En Los afroantillanos en Panamá, Maloney (2011) vuelve sobre el tema y propone que la población afropanameña se dividía en dos grupos: los afrocoloniales y los afroantillanos. Cada uno presentaba sus propias características históricas: pasado, idioma, apellidos, entre otras. Este segundo grupo está conformado mayoritariamente por jamaiquinos y barbadenses que arribaron en época de construcción de infraestructura. De nuevo, es clave para el autor la segregación racial en forma de explotación, lo que llevó a que esta experiencia creara un descontento acumulado que se manifestaría en los años posteriores a la culminación del canal. Esto desembocaría en una lucha sistemática en contra de la explotación, ya que toda la población seguiría siendo marginada por la sociedad panameña que los seguía considerando como extranjeros en tierras panameñas. Incluso después de que se asentaran y sus hijos nacieran en Panamá. Para Maloney, esta dinámica de exclusión se mantuvo hasta la década de 1960, cuando la sociedad panameña sufre un cambio bajo el gobierno de Omar Torrijos que se continuaría hasta la entrega del canal a Panamá. Durante este período hay una transformación que continúa hasta hoy y que lleva al antillano a convertirse en un miembro de la sociedad panameña. La lucha por el reconocimiento de esta población, el pasado y sus descendientes ha sido constante y va de la mano con su establecimiento como panameños.

En ¿Qué tan ajenos y qué tan extranjeros?: los antillanos británicos en América Central, 1870-1940, Putnam (2011) examina la movilidad 
poblacional en la zona del Caribe y América central. Partiendo de que este fenómeno era una constante en la segunda mitad del siglo XX, la autora ilustra estos movimientos en mapas y los divide en diferentes momentos, todo lo cual permite entender que el mundo atlántico de ese momento tenía gran movilidad y esta no se limitaba exclusivamente a la zona de Panamá. Propone, así mismo, que para finales del siglo diecinueve era usual encontrar en el istmo y en las islas, redes de migración que facilitaban la movilización de esta población, como ocurre en Costa Rica, por las plantaciones, y en Panamá, por la infraestructura.

En la vía de los autores mencionados, Putnam afirma que la mayor migración hacia el istmo fue panameña y barbadense, pero va más allá y le quita impacto a la permanencia de esta población luego de finalizadas las obras. Para ella, buena parte de esta población rehúsa volver a sus lugares de origen y ve en Panamá solo un lugar de empleo, aunque luego emigrarían hacia nuevas opciones de empleo, como la Cuba posterior a 1915, cuando aumentan los precios del azúcar y se necesita mano de obra. En su opinión, los antillanos se adaptaron a los contextos racistas de las compañías norteamericanas que permanentemente promovían la segregación en múltiples aspectos. Era frecuente que esta población también buscara empleo en zonas fuera de la influencia norteamericana, ya que preferían estar en contextos a cargo de los gobiernos no norteamericanos, algo que cambiaría en el siglo XX. En el XIX, la movilidad fluida entre las fronteras era permanente, pero en la década de 1920 se desarrolló un sentimiento racista en países centroamericanos. Esto se debió principalmente a la contracción en las exportaciones y la tendencia eugenésica que estaba en ascenso en el contexto internacional. Incluso, muchos antillanos nacidos en América Central o siendo tercera generación fueron expulsados hacia otros lugares, lo que reforzó el imaginario de una separación entre los caribeños británicos y los caribeños hispanohablantes, aunque en la realidad este imaginario tuvo poco asidero, ya que una gran parte de esta población tenía gran nivel de adaptación y se habían asentado en tierras adonde habían migrado décadas atrás.

En síntesis, la migración de antillanos a Panamá ha sido abordada según variedad de enfoques: algunos autores la tratan como un elemento de los procesos migratorios en el Caribe; otros, como un elemento 
colateral de los procesos de construcción de grandes obras de infraestructura y, finalmente, un grupo de investigadores la aborda como la causa de fenómenos poblacionales y raciales posteriores a la terminación de las obras.

Llegados a este punto, conviene resaltar el gran vacío en la historiografía sobre la temática poblacional y más específicamente sobre las migraciones: la migración de origen europeo. Este tema es poco abordado; se limita a menciones de la existencia de esta población y no hay trabajos específicos más allá de los fotográficos como el de Keller (1983) que, en The building of the Panama Canal in Historic Photographs, hace una recopilación de fotografías que dan cuenta de la construcción del canal y de muchos espacios en los que se vivía la cotidianidad del proyecto. Aparte de esta obra, difícilmente se encuentra un trabajo que muestre más allá de una mención en tablas estadísticas la presencia de población europea, lo que quizá pueda deberse a las pocas fuentes existentes o a la dispersión, pero al margen de cuál sea la razón, la información al respecto no excede el campo de lo anecdótico.

Este contexto es construido exclusivamente desde la revisión de historiografía, por lo cual la gran mayoría de sus argumentos ya han sido explorados antes por otros autores. Explora la llegada de los primeros migrantes a la zona del ferrocarril, las condiciones a las que se vieron sometidos, los conflictos con los irlandeses y las altas tasas de mortalidad. Seguido a esto hacen una aproximación a las dinámicas de establecimiento en otras zonas de Colombia y del Caribe. Por último, se centra en las organizaciones, su creación y en la forma en que se estabilizaron y asentaron en el territorio colombiano, especialmente en Bogotá.

En conclusión, los trabajos sobre la migración en dirección a Panamá en la segunda mitad del siglo XIX y primeros años del XX son muy variados, pero se destacan tres líneas de investigación. Una, la de quienes proponen que este fenómeno no fue exclusivo del istmo, sino que, por el contrario, es el ejemplo de una dinámica mucho más grande en la cual se dio una movilidad poblacional en el Pacífico y el Caribe por diferentes motivos. Este primer grupo se ha centrado en estudios generales sobre la migración o estudios específicos sobre la infraestructura de Panamá. En estos últimos la migración ha estado en un segundo plano, mientras que en los primeros es concebida como uno de los muchos que se dieron en la 
región. En todo caso, en ninguno de los dos enfoques la migración hacia Panamá en el período mencionado y con fines obreros ha sido central, $y$, por el contrario, se ha presentado como un asunto marginal y poco explorado en profundidad.

Un segundo grupo se centra en los procesos de migración antillana. Este es probablemente el tema más desarrollado en cuanto a historiografía. Trabajos como el de Newton (1995) han servido como pilar para erigir una historia de la migración antillana a la zona del ferrocarril y del canal, tema muy trabajado pero que aún deja muchas preguntas sin responder y son abordadas por los investigadores en períodos recientes.

\section{Migración e infraestructura del ferrocarril y del canal de Panamá}

La construcción, primero del ferrocarril de Panamá, a mediados del siglo XIX, y luego del canal, generó una profunda transformación en el istmo, toda vez que ambas obras de tránsito permitieron conectar de manera más eficiente el comercio interoceánico y convirtieron a Panamá en un escenario estratégico para la geopolítica global. La incorporación de la mano de obra necesaria para la construcción de ambas obras fue una problemática que debieron enfrentar los inversionistas y que, para el caso del ferrocarril, provocó migraciones de diversas partes del mundo, incluidas europeas, estadounidenses, chinas y de las islas del Caribe.

A continuación, exploraremos estos procesos desde dos perspectivas: por una parte, el modo como este fenómeno ha sido estudiado desde la literatura, y, por otra parte, desde un análisis acompañado de una revisión hemerográfica que permita evidenciar la manera como se registraban las discusiones sobre las migraciones con énfasis en las caribeñas. El período de análisis corresponde a 1849, momento en que se inicia la construcción del ferrocarril, y 1903, cuando Panamá se separa de Colombia. A fin de atender este objetivo, este apartado se divide en cuatro secciones. En la primera se presenta la revisión de la literatura; en la segunda se hace una síntesis de los procesos de construcción y puesta en marcha del ferrocarril y del canal interoceánico; en la tercera se presentan los hallazgos respecto de las migraciones caribeñas hacia Panamá en el marco de estas dos obras; y, por último, se exponen los comentarios finales sobre estos hallazgos. 


\section{Las dos rutas: férrea y acuática}

Como una ruta de paso entre el mar Caribe y el Pacífico, The Panama Railroad Company fue la primera línea férrea construida en Colombia. Desde la perspectiva empresarial, fue una de las empresas más rentables de su tiempo y reflejó con claridad los intereses económicos y políticos de EE. UU., no solo frente a América Latina, sino frente a sus competidores más fuertes en la región: Francia, Inglaterra y España. La empresa se constituyó en uno de los monopolios de transporte más importantes de la época (Correa, 2012).

La expansión geopolítica de EE. UU., junto con la fiebre del oro, generó incentivos importantes para el capital estadounidense y para el Gobierno de este país con miras a desarrollar un paso más seguro y expedito entre las costas estadounidenses mientras se regularizaba una ruta interna confiable. El Tratado Mallarino-Bidlack (1843) entre Colombia y EE. UU. fue el fundamento jurídico para avanzar en un proceso de inversión en Panamá que conduciría a la construcción, primero, del ferrocarril y más tarde, del canal (Weaver, 1992, pp. 153-155). John Stephens, William Aspinwall y Henry Chauncey firmaron, el 28 de diciembre de 1848, un contrato en Washington con Pedro Alcántara Herrán, en nombre del gobierno de José Hilario López para la construcción de una línea férrea transcontinental, con miras a lo cual se fundó la Panama Railroad Co. (Board of Directors, 1849, pp. 29-54). En agosto de 1850 se inició la construcción alrededor de Cerro Mono, que luego sería conocido como Monte Esperanza. Sin embargo, después de construidas siete millas, los ingenieros informaron a los inversionistas que el dinero se había terminado, con una inversión de poco más de un millón de dólares que no llevaba a ningún sitio.

Debido al mal tiempo, dos vapores que iban rumbo a California tuvieron que refugiarse en la bahía, por lo que alrededor de mil mineros desembarcaron en la isla Manzanillo. Tras contratar los servicios de este pequeño tramo para conectar con el río Chagres y continuar con su viaje, esto tuvo un efecto decisivo para la construcción del ferrocarril, pues la noticia disparó las acciones en Nueva York y la obra pudo continuarse sin escasez de recursos (Rippy, 1981). Las brigadas de construcción que avanzaban desde los dos frentes se encontraron y, para finales de enero de 1955, entró en funcionamiento el primer tren interoceánico y transcontinental de la historia. La extensión total era de 47,5 millas. La gran 
demanda por este ferrocarril lo convirtió por un tiempo en el más rentable del mundo, registrando incluso utilidades en 1868 por 4,3 millones de dólares. Pese a lo desigual de la concesión que se firmó con Colombia, nuestro país gozó de ingresos nada despreciables para las finanzas públicas, convirtiéndolo en uno de los recursos fiscales más importantes de la nación (Hull, 1999, pp. 13-15).La nueva concesión se firmó en 1867 y con ella se amplió el término a 99 años, con el pago de un millón de dólares y una anualidad de 250.000 al Gobierno colombiano; aparte del transporte de tropas, oficiales con equipaje, munición, armamento y otros productos sin cargo por parte de la compañía. Además, el nuevo contrato de concesión suprimió la restricción que tenía Colombia para otorgar privilegios de construcción de carreteras y de un canal en el istmo. Pese a esta modificación, se dio luz verde a una cláusula por la cual se protegían los intereses del ferrocarril, puesto que si el canal se construía en el eje Panamá-Colón, se indemnizaría a la compañía (Lemaitre, 2007). Por tal razón, Ferdinand de Lesseps fundó en París, junto con otros socios, la Société Internationale du Canal Interocéanique (luego Compagnie Universelle du Canal Interocéanique). En 1879, Lesseps comenzó a acumular importantes cantidades de suministros en Panamá, con un efecto inesperado para la línea férrea al obtener un aumento importante de carga transportada. No obstante, los costos de las tarifas de fletes resultaron demasiado altos para la compañía francesa y Lesseps decidió comprar 98,41 \% de las acciones (68.887 de las 70.000 disponibles) de la Panama Rairoad Co. Las acciones se dispararon de unos 60 dólares por acción a 291 dólares, para un total aproximado de 25 millones de dólares (93 millones de francos), que resultaba más barato que pagar los fletes.

La administración gala realizó mejoras y actualizaciones a la infraestructura, pero también adquirió una importante cantidad de maquinaria innecesaria, incluyendo palas de nieve, la construcción de un muelle en la ciudad de Panamá por el escandaloso valor de 2.220.357 dólares, 18 casas de lujo, entre otros bienes, lo que generó una extendida fama de corrupción (Hull, 1999, p. 15). Por todo esto, no pudo ser más deplorable el final de la Compagnie Universelle du Canal Interocéanique. Lesseps pasó sus años finales inmerso en un penoso proceso judicial que concluyó con su condena a dos años de prisión, al igual que su hijo Charles. Incluso Gustave Eiffel fue condenado a dos años por el mis- 
mo proceso, fundamentado en la pérdida financiera que tuvieron los 800.000 ahorradores que habían comprado los bonos de la compañía.

Este descalabro financiero llegó a lo más alto del Gobierno francés, obligando a la caída del gabinete del presidente Sadi Carnot y afectando la reputación del importante político Georges Clemenceau. Luego de estos penosos sucesos, los liquidadores de la Compagnie Universelle du Canal Interocéanique lograron, después de un difícil proceso, con los activos remanentes de la compañía, la constitución de una nueva empresa: Compagnie Nouvelle du Canal (Pérez, 2007). Al mismo tiempo, el Gobierno de EE. UU. insistía en la firma de un tratado con Colombia para construir un canal; empero, el Gobierno colombiano, a lo largo de 1901, dilató constantemente cualquier respuesta, y Marroquín, como vicepresidente, le hizo enconada oposición a toda iniciativa en este sentido.

Esta actitud fue vista en EE. UU. como una muestra de la corrupción reinante en Bogotá. Para colmo, el embajador en Washington, Carlos Martínez Silva, fue retirado por el Gobierno debido a su posición política. Su remplazo fue José Vicente Concha, quien, aparte de no hablar inglés, jamás había salido del país. Como directriz del canciller Abadía Méndez, Concha exigió al Gobierno estadounidense la suma de veinte millones de dólares por rescindir el contrato con los franceses (Turk, 1974).

En enero de 1903, luego de fuertes presiones por parte de EE. UU., se firmó el tratado Herrán-Hay, el cual concedió al país norteamericano el derecho a construir un canal y ocupar temporalmente una faja de terreno de cinco kilómetros de ancho a lado y lado de la línea que ocuparía el canal, a cambio de lo cual Colombia recibiría una compensación de 10.000.000 de dólares. En dos meses el Congreso de EE. UU. aprobó este tratado, pero su similar colombiano lo recibió con una actitud negativa y dilató las discusiones sobre el tema, pese a los airados reclamos de las autoridades de la Ciudad de Panamá. Por ello, el embajador estadounidense en Colombia, el señor Baupré, envió una amenazante comunicación al Congreso para instar a que se aprobara el tratado o Colombia sufriría las consecuencias (Pérez, 2007, p. 189). Bajo la bandera de un exacerbado nacionalismo, Marroquín y Caro se opusieron con éxito a que el Congreso aprobara el tratado. En respuesta, el presidente Roosevelt ordenó al Ejército y a la Fuerza Naval preparar los planes necesarios para evitar que Colombia impidiera la secesión de Panamá, estableciendo una 
directiva con la cual se iniciaba un bloqueo efectivo sobre las costas del Pacífico y el Caribe colombiano y se preparaban para ocupar los puertos de Cartagena, Santa Marta, Sabanilla y Buenaventura.

La precariedad de las tropas colombianas, que venían de la Guerra de los Mil Días, y la penosa situación fiscal, hicieron imposible emprender cualquier operación para recuperar el territorio panameño, que en la práctica era más un territorio insular que parte integral del país. La separación generó una difícil situación diplomática entre los Gobiernos colombiano y estadounidense que tardaría muchos años en solucionarse (Hendrix, 2006, pp. 36-42). Una vez reconocida la independencia de Panamá, el gobierno de EE. UU., gracias a la Ley Spooner del 28 de junio de 1902, adquirió en 1904 por 40 millones de dólares los derechos, privilegios, franquicias, concesiones, cesiones de tierras, derecho de tránsito, obras inconclusas, maquinaria y bienes raíces, que la Compaigne Nouvelle du Canal poseía en Panamá. Además, se firmó el tratado Buneau Varilla-Hay, por el cual se dio vía libre a la construcción del canal en territorio panameño. En mayo de 1904, el presidente Roosevelt creó la Comisión del Canal Ístmico para construir el canal, poniendo el ferrocarril bajo su jurisdicción ("Información política", El Colombiano, 12 noviembre de 1903). La construcción del canal duró diez años, pero esto es parte de la historia del nuevo país.

\section{Trabajadores migrantes y locales}

La construcción del ferrocarril a través de la selva panameña no fue tarea fácil. Aunque la mitología popular sostiene que debajo de cada traviesa yace enterrado un trabajador, esto es imposible, toda vez que en total eran más de 150.000 traviesas; pero sí da una idea bastante clara del imaginario popular alrededor del costo humano de la obra $(\mathrm{McCu}-$ llough, 1977, p. 37). Desde luego, el principal problema que debió enfrentar la compañía fue la necesidad de reclutar, disciplinar y mantener con vida una fuerza laboral suficiente para la construcción en condiciones adversas. Lo anterior se vio acentuado por la fiebre del oro en California, ya que una parte de la demanda de mano de obra para la minería aumentó significativamente, distrayendo parte del recurso humano necesario para la construcción del ferrocarril; incluso, en la prensa local 
se indicaba que para marzo de 1850 se registraba la llegada de cuarenta buques con personas en tránsito hacia California y se reclamaba que la mano de obra no era suficiente debido, entre otras razones, a que los 300 zapadores prometidos por el Gobierno colombiano no habían sido trasladados (M. A., 1850a, p. 1).

En la zona de tránsito de dicha mano de obra también aumentaron los precios, debido a la mayor demanda por suministros y bienes, y se incrementaron los salarios debido a la escasez de brazos disponibles (McGuinness, 2008, p. 55). Por otra parte, trabajadores de diferentes partes del mundo participaron en la construcción del ferrocarril: jamaiquinos, martiniqueños, alemanes, portugueses, irlandeses, indios, austriacos, chinos y colombianos. Durante el tiempo de la obra se contrataron entre seis mil y siete mil personas, la mayoría de ellos provenientes de Jamaica o de Cartagena. ${ }^{134}$ Incluso, inicialmente se utilizó mano de obra esclava, pero los cambios legales que se introdujeron con las Reformas Liberales y que conducirían a la manumisión de los esclavos entre 1851 y 1852, sumados a las posibles repercusiones políticas en Nueva York y la oposición de Tomás Cipriano de Mosquera a su uso, hicieron que la empresa abandonara esta iniciativa (McGuinness, 2008, p. 59; M. A., 1850a, p. 1).

Para enfrentar esas dificultades, hubo un intento inicial de contratar mano de obra cartagenera, para lo cual Totten debió trasladarse a esta ciudad a fin de tratar de convencer personalmente a los posibles trabajadores, pues la mayoría consideraba que Panamá era demasiado peligroso e insalubre para trasladarse.

Fue mediante contratos de seis meses como logró contratarse mano de obra, pero la precaria infraestructura inicial, los rigores de la temporada de lluvias y las dificultades propias del tipo de trabajo ocasionaron que los trabajadores en gran número abandonaran la obra (McGuinness, 2008, p. 59; Oran, 1858/2004 p. 23).En diciembre de 1849, se publicaba en la prensa panameña la noticia sobre el próximo inicio de la obra del ferrocarril y la contratación en Nueva York "de 100 obreros de primera clase" junto con los ingenieros (M. A., 1849, pp. 1-2).

134. En términos generales, se hace referencia a la migración de cartageneros, aunque en la práctica es una mención genérica a la población proveniente del departamento de Bolívar en Colombia (o del Estado Soberano de Bolívar antes de la Constitución de 1886). 
La mano de obra extranjera enganchada, empero, comenzó con un desastroso intento de vincular mano de obra irlandesa. Los primeros cincuenta se contrataron en Nueva Orleans, no en Nueva York, por un término de seis meses a cambio de un pasaje a California, a un costo que osciló entre 15 y 50 dólares por persona (Cohen, 1971, p. 311; Oran, 1858/2004, p. 23). La transacción se hizo a través de la firma Baker and Truesdale, que logró enganchar cerca de 400 trabajadores y su llegada comienza a registrarse en septiembre de 1850 (McGuinness, 2008, p. 63; M. A. 1850b, pp. 2-3). Totten insistía en 1850 en la contratación de mano de obra cartagenera, la cual conocía por su experiencia en la construcción del canal del Dique y había gestionado la vinculación de 600 obreros que llegarían en grupos de 150 personas al mes. Igualmente, seguía discutiéndose la posibilidad de vincular esclavos pese a los cambios políticos en este sentido; así como la vinculación de cien obreros estadounidenses "de primera clase" (M. A. 1850c, pp. 1 y 2). También para 1850 se registró el primer arribo de mano de obra jamaiquina con la llegada de 300 obreros al área de construcción en la isla de Manzanilla, para un total de 1.000 personas en este frente de trabajo. La introducción de estos obreros fue considerada por la prensa local como un "ensayo exitoso" que se sumaba a los obreros cartageneros contratados por Totten (M. A. 1850d, p. 2; M. A. 1850 b, p. 2).

A finales de ese mismo año estaban vinculados a la obra cerca de 500 obreros estadounidenses (M. A. 1850e, p. 1 y 2; M. A. 1850f, p. 3), si bien las enfermedades y las difíciles condiciones rápidamente cobraron la vida de parte de estos trabajadores. Por si fuera poco, unos 150 entraron rápidamente en huelga, frente a lo cual la empresa suspendió los contratos y se embarcaron de nuevo a Nueva York, donde algunos de ellos también murieron a causa de las enfermedades que habían contraído (Otis, 1867, p. 35).

Lo anterior generó una serie de notas de prensa en las que incluso se afirmaba en el Sun de Nueva York y otros periódicos estadounidenses que la tasa de mortalidad era tan alta que se registraba un muerto por cada pie construido; desde luego, la compañía respondía que esto era "absurdo, pues en 1853 se habían construido 22 millas lo que implicaría que más de 33.000 obreros habrían muerto en este período" ("El ferrocarril de Panamá i sus antagonistas” El Panameño, 29 mayo de 1853, p. 3). 
Más allá de la discusión sobre las cifras, a todas luces imposibles, lo evidente es una situación clara de preocupación respecto de lo que había ocurrido con los obreros estadounidenses. Era notoria la insistencia en contratar mano de obra extranjera, pues consideraban que la mano de obra local - mestiza, india y negra - era perezosa, indolente, ineficiente y poco acostumbrada a trabajar, para confiarles la construcción a largo plazo (Oran, 1858/2004, p. 20). ${ }^{135}$

El coronel Totten reportó a la Junta Directiva un total 1.590 trabajadores activos en 1850, que se discriminaban en unos 1.200 trabajadores nativos, jamaiquinos y chinos y 390 trabajadores blancos. Además, solicitó apropiar los fondos necesarios para aumentar el número de trabajadores cartageneros a 2.000, de otras partes de la Nueva Granada a 500, 1.700 trabajadores chinos y 1.000 irlandeses, para un total de 6.790 trabajadores (Board of Directors \& Totten, George M., 1853, p. 18). Pese a los lamentables resultados de los trabajadores irlandeses, Totten consideraba que aún podían ser útiles para trabajos manuales.

Por último, la mano de obra local y cartagenera era considerada por Totten como la más apta para el trabajo manual y, después de los chinos, la más barata. En dicho reporte puede apreciarse con claridad la visión cultural de Totten frente a la segmentación del trabajo manual y técnico, y qué ventajas ofrecía cada uno de los segmentos poblacionales frente a los otros (Board of Directors \& Totten, George M., 1853, p. 18).

La empresa decidió contratar trabajadores jamaiquinos y cartageneros, predominantemente de raza negra y mulatos, pues "parecía" que dicha mano de obra estaba mejor adaptada a las condiciones de la zona. Cuántas pérdidas de vidas y cuántas tragedias humanas se habrían evitado si se hubiera pensado lo obvio desde el principio: que la población local está mejor adaptada a la zona que la mano de obra foránea. Tanto la población jamaiquina como la cartagenera se habían asentado para 1881 en Panamá y la mayor parte se había dedicado a negocios mercantiles y vivía con sus familias en las ciudades de Colón y Panamá, aunque

135. Descripciones similares pueden encontrarse en textos como el de J. T. Headley, en el cual se describe a los indígenas del Darién como "traicioneros" y a los neogranadinos en general como "patéticos, perezosos y egoístas", aunque él mismo nunca viajó a esta región y hace sus descripciones a partir de los testimonios y diarios de viaje de la expedición del teniente Isaac C. Strain a través del Darién (Headley, 1855/2004). 
no eran extraños los reportes de prensa que hablaban de situaciones de orden público referidos a esta población, en contraste con la población "civilizada" de los inmigrantes estadounidenses y europeos que tenían residencia en estas ciudades ("La vida en Panamá", El Cronista, 7 junio de 1881 , p. 879).

Luego, a comienzos de 1882, se evidencia una reactivación de la migración jamaiquina para participar en las obras del canal bajo la administración francesa, al tiempo que se registran huelgas de trabajadores descontentos por las condiciones laborales y los pagos de salarios ("Huelga", El Cronista, 7 enero de 1882, p. 1.116). En 1883, se registran fricciones entre los trabajadores cartageneros y jamaiquinos en Panamá en los que parecen ser frecuentes los enfrentamientos violentos en la medida en que se informan de retrasos importantes en la obra del canal debido a sus características técnicas y no a la falta de mano de obra o de materiales ("Sucesos de Culebra”, El Cronista, 17 noviembre, 1883, p. 1.788). Así mismo, se planteó en 1883 la posibilidad de "regular" la migración de extranjeros en una propuesta que definía la emigración de italianos a otras partes de Europa, la cual podía ser utilizada como ejemplo en Colombia para el control de la población migrante china y jamaiquina que trabajaba en el canal, con un registro adicional de las condiciones de localización, salarios, garantías ofrecidas, entre otros elementos ("La migración en Italia", El Cronista, 20 junio, 1883, p. 1.792). Cuatro años más tarde, en 1887, se expide una nueva normatividad para diferenciar los extranjeros "residentes o transeúntes", la cual se define por medio de un registro formal frente a las autoridades competentes. Igualmente, la ley define los diferentes tipos de residencia, así: la de cuatro años, la residencia unida a la adquisición de tierras, la residencia unida al ejercicio del comercio y haber contraído matrimonio con una colombiana, la cual es definida como un "ánimo presunto de permanencia ("Interior", El Cronista, 23 junio de 1887, p. 511). El periódico El Cronista publicó en 1887 una noticia en la que se informa de la llegada de "africanos" a Panamá con motivo de la construcción del canal. El texto afirma que esto es consecuencia de que, para el momento, solo quedaban pocos trabajadores en la obra, algunos colombianos y otros jamaiquinos. Sin ocultar un tono racista y xenófobo, el articulista describe esta mano de obra como "salvajes, antropófagos, consumidores de carne cruda, de naturaleza feroz y violenta y que viven 
completamente desnudos". Además, continúa la noticia, "no hablan español, ni francés o inglés", a pesar de que la compañía indicaba que así era ("Los sucesos de la culebra", El Cronista, 17 noviembre, de 1887, p. 663). Ya en el nuevo siglo, en 1902, frente a la suspensión de actividades en la construcción del canal aunado por los efectos de la Guerra de los Mil Días, el gobernador de Panamá escribió una advertencia a Jamaica para evitar que continuara el proceso migratorio, debido a que las posibilidades de trabajo eran escasas y las perspectivas eran negativas ("Warning to Jamaican Labourers", The Colon Starlet, 27 febrero de 1902, p. 1).

Al final de la guerra y frente a la separación de Panamá, sin embargo, se evidenciaba que agentes de inmigración en Jamaica podrían dar libertad para que se dieran contratos y la migración de trabajadores. Pese a estas intenciones, no se presentó una migración significativa en el siglo XX alrededor de la construcción del canal por parte de EE. UU. y el gobernador de Jamaica le advertía a su población sobre su negativa a fomentar las migraciones a Panamá debido a que las oportunidades para ese momento eran aún inciertas ("Jamaica Inmigration Departament", The Colon Starlet, 24 febrero de 1903, p. 1; "West Indians. Jamaica”, The Panama Star and Herald, 29 abril de 1903, p. 1).

\section{A manera de comentario final}

En general, los registros de la mano de obra y de los muertos en la construcción son bastante dispersos e incompletos debido a que solo hay algún acervo de estadísticas referentes a la mano de obra blanca. Igualmente, la información disponible en los archivos colombianos es muy limitada y los datos censales no ahondan en diferenciaciones que permitan dar cuenta cierta de la magnitud de la migración caribeña hacia Panamá como consecuencia de las dos grandes obras de infraestructura iniciadas en el siglo XIX: el ferrocarril y el canal.

Se puede evidenciar, no obstante, un vector dominante de migración jamaiquina hacia Panamá, aunque su magnitud no es fácil de cuantificar. Las referencias en la prensa local y en la literatura disponible mencionan de manera permanente esta situación, sumada a la migración, interna para el momento, de la población proveniente del departamento de Bolívar en Colombia. Por lo que puede deducirse de las fuentes disponibles, 
Infraestructura ferroviaria y migración en Panamá, siglos XIX y XX

esta población migrante no solo se dedicó a las labores propias de la construcción como obreros calificados y no calificados, sino que se asentó y se dedicó a actividades comerciales, probablemente minoristas, y agrícolas. Así mismo, puede inferirse que su asentamiento estuvo asociado a mejores oportunidades laborales y la conformación de núcleos familiares.

\section{Referencias}

Board of Directors y Totten, G. M. (1853). Communication of the Board of Directors of the Panama Railroad Company to the Stockholders together with the Report of the Chief Engineer to the Directors. Nueva York: John F. Trow Printer.

Board of Directors (1849). Panama Rail-Road Company. Nueva York: Van Norden Amerman.

Cohen, L. (1971). The chinese of the Panama Railroad: preliminary notes on the migrants of 1854 who "failed". Ethnohistory, 18(4), 309-320.

Conniff, M. (2004). Panamá durante la época de construcción del Canal norteamericano. En A. Castillero, (ed.), Historia general de Panamá (t. 1, vol. 3, pp. 24-33). Panamá: Comité Nacional del Centenario de la República.

Correa, J. (2010). Inversión extranjera directa y construcción de ferrocarriles en Colombia: el caso del ferrocarril de Panamá (1849-1869). Estudios gerenciales, 26(115), 141-160.

Correa, J. (2012). The Panama Railroad Company o cómo Colombia perdió una nación. Bogotá: Editorial CESA.

El ferrocarril de Panamá $i$ sus antagonistas (Anon., 1853). El Panameño, 29 mayo, p. 2.

Figueroa, A. (1978). Dominio y sociedad en el Panamá colombiano (1821-1903). Panamá: Imprenta Panamá.

Headley, J. T. (2004). Darien Exploring Expedition, under command of lieut Isaac C. Strain. En M. LaRosa y G. Mejía (eds.), The United States discovers Panama: the writings of soldiers, scholars, scientist, and scoundrels, 18501905 (pp. 45-82) (original publicado en 1855). Estados Unidos: Rowman \& Littlefield Publishers, Inc.

Hendrix, H. J. (2006). TR's Plan to invade Colombia. Naval History, 20(7), 36-42. Huelga (Anon., 1882). El Cronista, 7 enero, p. 1116.

Hull, G. (1999). Panama’s Transcontinental Railroad. National Railway Bulletin, 64(5), 4-35.

Información política (Anon., 1903). El Colombiano, 12 noviembre.

Interior (Anon., 1887). El Cronista, 23 junio, p. 511. 
Jaén, O. (1979). La población del istmo de Panamá del siglo XVI al siglo XX: estudio sobre la población y los modos de organización de las economías, las sociedades y los espacios geográficos. Panamá: Impresora de la Nación.

Jaén, O. (1981). Hombres y ecología en Panamá. Panamá: Editorial Universitaria; Smithsonian Tropical Research Institute.

Jamaica Inmigration Departament (Anon. 1903). The Colon Starlet, 24 febrero, p. 1. Johnson, M. (2011). Las migraciones laborales en las islas del Caribe. En R. Cáceres (ed.), Del olvido a la memoria: nuestra herencia afrocaribeña (pp. 7-14). San José: UNESCO Office. San José. Recuperado de https://unesdoc. unesco.org/ark:/48223/pf0000259514

Keller (1983). The building of the Panama Canal in Historic Photographs. Nueva York: Dover.

La migración en Italia (Anon., 1883). El Cronista, 20 junio, p. 1792.

La vida en Panamá (Anon., 1881). El Cronista, 7 junio, p. 879.

Lemaitre, E. (2007). Panamá y su separación de Colombia.

www.lablaa.org/blaavirtual/historia/panam/indice.htm [Consultado: 26 junio 2020].

Los sucesos de La Culebra (Anon., 1887). El Cronista, 17 noviembre, p. 663.

M. A. (1849). Ferro-Carril. El Panameño, 9 diciembre, pp. 1-2.

M. A. (1850a). Para el extranjero. El Panameño, 31 marzo, p. 1.

M. A. (1850b). Comunicación Intermarina núm. 41. El Panameño, 15 septiembre, pp. 2-3.

M. A. (1850c). Comunicación intermarina núm. 28. El Panameño, 7 abril, pp. 1 y 2.

M. A. (1850d). Comunicación Intermarina núm. 37. El Panameño, 4 agosto, p. 2.

M. A. (1850e). Comunicación Intermarina núm. 43. El Panameño, 13 octubre, pp. 1-2.

M. A. (1850f). Comunicación Intermarina núm. 49. El Panameño, 29 diciembre, p. 3.

Mack, G. (1992). La tierra dividida: historia del canal de Panamá y otros proyectos del canal ístmico. Panamá: Editorial Universitaria.

Maloney, G. (1999). El canal de Panamá y los trabajadores antillanos. Panamá 1920: cronología de una lucha. En L. Navas (ed.), El movimiento obrero en Panamá (1880-1914) (pp. 323-362). Panamá: Autoridad del Canal.

Maloney, G. (2004). Significado de la presencia y contribución del afropanameño en la nación panameña. En A. Castillero (ed.), Historia general de Panamá (t. 1, vol. 3, pp. 152-171). Panamá: Comité Nacional del Centenario de la República. 
Infraestructura ferroviaria y migración en Panamá, siglos XIX y XX

Maloney, G. (2011). Los afroantillanos en Panamá. En R. Cáceres (ed.), Del olvido a la memoria: nuestra herencia afrocaribeña (pp. 77-82). San José: UNESCO Office. San José. Recuperado de https://unesdoc.unesco.org/ ark:/48223/pf0000259514

Marín, G. (2009). La inmigración internacional en el Caribe panameño vista a través de los censos. Revista Estudios, (22), 331-347.

McCullough, D. (1977). The path between the seas: the creation of the Panama Canal, 1870-1914. Nueva York: Simon and Schuster.

McGuinnes, A. (2001). In the path of empire: labor, land and liberty in Panama during the California gold rush. Ann Arbor: UMI.

McGuinnes, A. (2004). Aquellos tiempos de California: el ferrocarril de Panamá y la transformación de la zona de tránsito durante la fiebre del oro. En A. Castillero (ed.), Historia General de Panamá (t. 1, vol. II, pp. 141-159). Panamá: Comité Nacional del Centenario de la República.

McGuinnes, A. (2008). Path of the empire: Panama and the California Gold Rush. Ithaca: Cornell Press.

Navas, L. (1999). El movimiento obrero en Panamá (1880-1914). En L. Navas (ed.), El movimiento obrero en Panamá 1880-1914 (pp. 3-148). Panamá: Autoridad del Canal.

Newton, V. (1995). Los hombres del "Silver Roll": migración antillana a Panamá. Sociedad de Amigos del Museo Afroantillano de Panamá.

Oran (2004). Panama Railroad. En M. LaRosa y G. Mejía (eds.), The United States discovers Panama: the writings of soldiers, scholars, scientist, and scoundrels, 1850-1905 (pp. 15-40) Estados Unidos: Rowman \& Littlefield Publishers, Inc.

Otis, F. N. (1867). History of the Panama Railroad and of the Pacific Mail Steamship Co. Nueva York: Harper \& Brothers.

Pérez, G. (2007). Nos dejó el tren: la historia de los ferrocarriles colombianos y los orígenes del subdesarrollo. Bogotá: Ediciones Cisnecolor.

Putnam, L. (2011). ¿Qué tan ajenos y qué tan extranjeros?: los antillanos británicos en América Central, 1780-1940. En R. Cáceres (ed.), Del olvido a la memoria: nuestra herencia afrocaribeña (pp. 22-36). San José: UNESCO Office. Recuperado de https://unesdoc.unesco.org/ark:/48223/pf0000259514

Reyes, E. (2000). El trabajo de las mujeres en la historia de la construcción del canal de Panamá. Panamá: Instituto de la Mujer; Universidad de Panamá.

Rippy, F. J. (1981). El capital norteamericano y la penetración imperialista en Colombia. Bogotá: El Áncora Editores.

Sucesos de La Culebra (Anon., 1883). El Cronista, 17 junio, p. 1788. 
Turk, R. (1974). The United States Navy and the 'Taking' of Panama. Military Affairs, 38(3), 92-96.

Warning to Jamaican Labourers (Anon., 1902). The Colon Starlet, 27 febrero, p. 1. Weaver, T. (1992). Los indios del Gran Suroeste de Estados Unidos: veinte siglos de adaptaciones culturales. España: Abya Yala.

West Indians. Jamaica (Anon., 1903). The Panama Star and Herald, 29 abril, p. 1. Westerman, G. (1999). Los inmigrantes antillanos en Panamá. En E. Wolfschoon, E. (ed.), Panamá, sus etnias y el canal (pp. 11-96). Panamá: Autoridad del Canal. 



\section{Los haitianos de Miami: ¿una comunidad en vías de integración? ${ }^{136}$}

\section{Cédric Audebert}

Laboratoire Caribéen de Sciences Sociales, (CNRS - Université des Antilles)

\section{Introducción}

Durante la segunda mitad del siglo XX, Miami se afirmó como una interfaz entre América Latina y Estados Unidos (Boswell, 1991; Girault, 2003, 2015; Global Cities Initiative, 2012) y un importante polo de inmigración para las poblaciones caribeñas (Wilson y Portes, 1980; Pedraza-Bailey, 1985; Allman, 1987; Grenier y Stepick, 1992; Portes y Stepick, 1993; Boswell, 1994; Grosfoguel, 1997), hasta el punto de ser calificada por las ciencias sociales de ciudad paradigmática que en cierta medida prefigura la evolución de la sociedad estadounidense (Nijman, 2000; Allman, 2015).

A las puertas del Caribe, la región de Miami se ha internacionalizado gracias a su capacidad para atraer capitales y migrantes latinoamericanos y a desarrollar una función de mando a escala de las Américas en los servicios, las finanzas, los transportes, la logística, las comunicaciones y la industria cultural (Nijman, 2010). La metrópoli se ha convertido en una encrucijada global que se apoya en

136. Este trabajo es parte del proyecto "Connected Worlds: The Caribbean, Origin of Modern World". This project has received funding from the European Union's Horizon 2020 research and innovation programme under the Marie Sklodowska Curie grant agreement N. ${ }^{\circ} 823846$. Professor Consuelo Naranjo Orovio, Instituto de Historia-CSIC, directs this project. 
la articulación de sus territorios étnicos con los campos migratorios transnacionales que la conectan con los países del Caribe. Esta ciudad multicultural se nutre de la globalización migratoria (Audebert, 2015). Ahora, $15 \%$ de los nuevos inmigrantes que llegan a Estados Unidos provienen del Caribe (U.S. Department of Homeland Security, 2020, Supplemental Table 2). La tercera parte de la población nacida en las islas del Caribe y que vive en Estados Unidos reside en el espacio metropolitano de Florida del Sur, según el censo estadounidense. Es el caso de dos tercios de los migrantes cubanos y de 20\% de los migrantes jamaicanos (US Census, 2019). Los haitianos no se apartaron de la regla y se dirigieron cada vez más hacia Florida desde la década de 1970 (Anglade, 1982; Stepick, 1981, 1982, 1992, 1998; Portes y Stepick, 1993; Audebert, 2006, 2015, 2020). En la parte meridional de este estado, su peso demográfico se ha vuelto significativo. Florida concentra ahora la mitad de los 700 mil nativos haitianos que residen en Estados Unidos (US Census, 2019). Más de 250 mil de ellos viven en el área metropolitana de Miami, de los cuales 88 mil viven en el condado de Miami-Dade. ${ }^{137}$ Los barrios haitianos de Miami se estructuran con relación al rol de lugar-soporte que desempeñan en el desarrollo de redes transnacionales con el país de origen.

Vista la amplitud de esta inmigración y la rapidez de su desarrollo en los últimos cuarenta años, parece oportuno interrogarse sobre los fundamentos históricos y sociales de la estructuración comunitaria de esta población y sobre su dinámica geográfica en la ciudad. ¿En qué medida el perfil demográfico, cultural y socioeconómico de la población migrante haitiana permite comprender su organización y su inserción en el espacio de Miami y la distingue de otros grupos etnoculturales? ¿Cuáles son las traducciones espaciales de la dinámica demográfica y social de esta comunidad desde hace más de cuarenta años? Nuestro estudio de las características históricas, demográficas y sociales de esta población permitirá comprender mejor las modalidades de su estructuración social y comunitaria y la lógica de su expansión espacial.

Los haitianos se caracterizan por una serie de particularidades demográficas, culturales, sociales y económicas que les confieren una singularidad

137. Hay que precisar que, de esas 88.000 personas nacidas en Haití, 82.000 reivindican una ascendencia haitiana y 6.000 un origen no haitiano (U.S. Census Bureau, 2019). 
en su entorno de asentamiento, en comparación con otros grupos etnoculturales con los que comparten el espacio. Elementos vinculados tanto al patrimonio cultural e histórico del grupo migrante como al funcionamiento de la sociedad de asentamiento contribuyeron a la formación de una comunidad etnocultural haitiana distinta en el sur de Florida, cuya territorialización haya sido un elemento de visibilidad en el espacio de una de las siete aglomeraciones urbanas más pobladas de Estados Unidos.

En el entorno de la sociedad de acogida, veremos que la población haitiana ha sido construida como una triple minoría inserta en la parte inferior de la escala socioeconómica. Sin embargo, la transformación social de la comunidad haitiana de Miami y su diversificación le abrieron el campo de las oportunidades y contribuyeron a desarrollar el espacio de vida de los inmigrantes en la metrópoli. El marco de estudio de este capítulo se limitará al condado de Miami-Dade, que es el lugar originario de la implantación de la población haitiana y que sigue siendo el marco administrativo de referencia cuando se alude al área metropolitana primaria de Miami (primary metropolitan statistical área).

\section{La formación de una comunidad etnocultural haitiana en Miami}

El hecho comunitario haitiano en Miami se ha construido sobre la base de elementos explicativos tanto internos como externos. En el plano externo, las contradicciones de la política migratoria estadounidense y las luchas suscitadas por el reconocimiento de los derechos de los haitianos en los decenios de 1970 y 1980 desempeñaron un rol fundamental en la construcción de una conciencia etno-comunitaria (Stepick, 1981 y 1982).

Desde finales de los años cincuenta hasta mediados de los ochenta, el estrecho control ejercido por la dictadura sobre la sociedad tuvo como consecuencia la desaparición de la mayoría de los espacios de libertad en Haití (Hurbon, 1987). En la década de 1970 y a comienzos de la de 1980, la mayoría de la población haitiana de la ciudad compartía el destino común de boat people que huyeron de la dictadura duvalierista (Stepick y Portes, 1986) y, luego, de los regímenes militares posduvalieristas. Una parte sustancial de los migrantes por barco vinieron también de las Bahamas, donde decenas de miles de haitianos habían migrado anteriormente y habían sufrido varias formas de discriminación y rechazo (Marshall, 
Los haitianos de Miami: ¿una comunidad en vías de integración?

1979; Craton, 1995; Perry, 2014). El golpe de Estado de 1991 en Haití que derrocó a Aristide prolongó los flujos migratorios por barco hacia Florida. En total, se estima que más de 100.000 haitianos llegaron por mar a Florida entre mediados del decenio de 1970 y mediados del decenio de 1990 (Stepick, 1998; Audebert, 2012). Después de una travesía marítima en condiciones peligrosas, aquellos que tuvieron la suerte de llegar vivos a las costas de Florida fueron expuestos a las persecuciones de una administración norteamericana particularmente intransigente hacia ellos (Stepick, 1992).

Lo que comenzó como una condición desfavorable para el asentamiento de los haitianos resultó ser un elemento determinante en la constitución de un embrión de comunidad en el corazón de la ciudad. Frente a la hostilidad de las autoridades, las acciones sucesivas del Black Caucus y del senador Edward Kennedy en el Congreso, así como de los dirigentes de la lucha por los derechos civiles y de las iglesias (National Council of Churches) han logrado influir en la política del gobierno federal (Alex Stepick, 1981). A comienzos de la década de 1980, se creó el estatuto $\mathrm{Cu}$ ban Haitian Entrant por el Ministerio de Justicia a los cubanos y a los haitianos que habían llegado antes del 10 de octubre de 1980. Esto permitió que decenas de miles de haitianos residieran legalmente en Florida. Al mismo tiempo, tuvo importantes implicaciones en su inserción en el mercado laboral local (Portes y Stepick, 1985). En 1986, la Ley de Reforma y Control de la Inmigración permitió a los titulares del Cuban Haitian Entrant obtener el estatuto de residente permanente, e incluso la ciudadanía estadounidense para quienes estanan presentes desde hacía al menos cinco años en el país. Muchos trabajadores agrícolas haitianos de Florida también se beneficiaron de esta legislación. La ley de 1990 amplió la posibilidad de acceder al estatuto de residente mediante la reagrupación familiar, con efectos inmediatos en la estructuración del barrio de la Pequeña Haití en el corazón de la ciudad de Miami (Audebert, 2006).

A estos factores externos vinculados a la política migratoria se conjugaron elementos explicativos internos de la estructura del grupo inmigrante en comunidad. Junto con estos elementos coyunturales históricos, el patrimonio sociocultural compartido por los migrantes de las regiones del norte y del noroeste de Haití ha constituido la base fundamental de la creación de solidaridades étnicas que han facilitado la acogida de los 
recién llegados en particular. La conservación de prácticas y referencias culturales relacionadas con la lengua criolla, la notable imbricación entre el vudú y el cristianismo, y una estructura familiar ampliada y matrifocal ha constituido un verdadero cimiento sociocultural para las comunidades haitianas del sur de Florida.

El caso del barrio de la Pequeña Haití permite observar el rol fundamental de la religión en la vida social de la comunidad, ya que el barrio cuenta en promedio con una iglesia por cada mil habitantes y registra las tasas de frecuentación de iglesias más altas de Estados Unidos. Durante los años 90 y sobre todo a partir de 2000, la territorialización religiosa observada en la Pequeña Haití se duplicó en las nuevas zonas de asentamiento de esta población en el norte del área metropolitana (Audebert, 2002). La espacialización de la práctica religiosa se ha inmiscuido en el espacio mercantil, con el desarrollo de las botánicas donde se compran artículos utilizados en las ceremonias vudú. La multiplicación de estas tiendas, siguiendo el modelo de las botánicas cubanas de la Pequeña Habana dedicadas a la santería, muestran la porosidad de los espacios comerciales y religiosos en la comunidad haitiana.

En el plano lingüístico, la identidad haitiana de Miami se construye en el desarrollo de relaciones con las otras comunidades etnoculturales de la ciudad. En este marco, la articulación entre la práctica del criollo haitiano y los otros idiomas hablados en Miami es un signo del surgimiento de una nueva identidad diaspórica haitiana de Miami. La mitad del 98\% de los nativos de Haití que hablan criollo o francés en Miami también dominan perfectamente el inglés estadounidense.

El conjunto de estos elementos de estructuración interna se ve reforzado por la existencia de referencias históricas fundadoras en la construcción de una identidad de diáspora que los haitianos de Miami comparten con otras comunidades haitianas en Estados Unidos. Una de esas referencias comunes es la memoria compartida de la independencia temprana de Haití en 1804 frente a Francia, una de las mayores potencias marítimas y coloniales europeas de entonces, tras una guerra de liberación contra el sistema esclavista. El ostracismo resultante de las potencias coloniales contribuyó a aislar a Haití en el plano externo durante gran parte del siglo XIX y a alimentar el nacionalismo haitiano. A esta memoria esencial en la construcción de un sentimiento de pertenencia nacional y su perpetuación 
en la diáspora se añade otro elemento memorial: el de la ocupación militar estadounidense de Haití (1915-1934) y sus consecuencias migratorias (Castor, 1971; Lemoine, 1981; Lundhal, 1982; Perusek, 1984). Entre los originarios de las provincias del sur y del noreste de Haití, la memoria de estas migraciones hacia Cuba y la República Dominicana sigue viva. Por último, la memoria de las atrocidades del duvalierismo y de la lucha contra este régimen dictatorial ha venido a consolidar la estructuración de una conciencia diaspórica, primero en Nueva York y después en Miami. En el sur de Florida, el sentimiento de las clases populares haitianas de pertenecer a una misma comunidad de destino se vio reforzado por la experiencia de "boat people", que muchos ya compartieron en los años 70 y que los distingue de las comunidades haitianas de Nueva York, Boston o Montreal (Buchanan Stafford, 1992; Basch et al., 1994; Laguerre, 1998; Glick Schiller y Fouron, 1999; Glick Schiller y Fouron, 2001; Pierre-Louis, 2006; Jackson, 2011; Audebert, 2012).

Otro factor explicativo de la formación del grupo migrante en comunidad fue su concentración espacial inicial. A principios de los años setenta, el peso demográfico de los haitianos no fue significativo ni en Miami ni en el resto de Florida. De hecho, aunque algunos intentaron llegar a Florida por mar, este tipo de migración siguió siendo muy marginal y la gran mayoría de los haitianos que emigraron a los Estados Unidos en esa época todavía lo hacían por vía aérea, hacia Nueva York y otras ciudades del noreste del país. La población haitiana de Miami apenas representaba unos pocos miles de personas a mediados del decenio de 1970 y no parecía lo suficientemente grande como para establecer una presencia espacial identificable en un barrio de la ciudad. Tanto más cuanto que esta población de inmigrantes recientes todavía tenía dificultades para estructurarse debido a su dificultad para acceder a un estatuto legal. Sin embargo, en la segunda mitad de los años setenta, la creciente presión demográfica vinculada a la llegada de decenas de miles de boat people y su concentración en el barrio central popular de "Edison-Little River" inició una dinámica de apropiación urbana inédita para ese grupo (Ladner et al., 1983; Deckelbaum, 1983; Audebert, 2006). Hasta la década de 1960, la población del barrio era principalmente blanca no hispana y obrera. Luego, los cubanos se instalaron allí al mismo tiempo que los afroestadounidenses que llegaban del gueto vecino de Liberty City. 
En el contexto de desegregación de los años setenta, los blancos abandonan el barrio, los cubanos se relocalizan en los sectores hispanos (Hialeah), y $80 \%$ de la zona se volvió negra (Mohl, 1991; Stepick, 1992). Las mutaciones etno-demográficas y raciales generaron una sensible baja de los alquileres, y se presentó la oportunidad para los haitianos de poder instalarse en gran número en el barrio. A comienzos de los años 80, el barrio central de Edison-Little River se convirtió en la "pequeña Haití" de Miami.

\section{Una triple minoría inserta en la parte inferior de la escala socioeconómica}

La historia social y migratoria del grupo y el contexto local de asentamiento permitieron a los migrantes de Haití ser reconocidos desde los años 80 como una comunidad etnocultural en Miami. En el contexto institucional multicultural de la sociedad estadounidense, el reconocimiento como comunidad de intereses por parte de las autoridades locales es importante, ya que permite a la población migrante acceder con facilidad a los recursos públicos y estar representada políticamente como comunidad étnica, a pesar del acceso más tardío a la ciudadanía del país de acogida en comparación con otras poblaciones migrantes. Estos elementos contextuales explican también la relativa singularidad cultural de esta población que se caracteriza por una situación de triple minoría en el contexto de Miami, como negra, no hispana y criollo-hablante. La otra herencia vinculada a la historia migratoria de boat people de los haitianos de Miami sigue siendo el perfil social singular de una población relativamente pobre.

Hasta el decenio de 1990, el noreste de Estados Unidos era el principal destino de los recién llegados de Haití. En 1990, más de la mitad de los haitianos del país residían en la región metropolitana de Nueva York. Con el tiempo, el sur de Florida se convirtió en la principal área de concentración de la población haitiana en Estados Unidos. Hoy día, 35\% de los 700.000 nativos de Haití registrados en Estados Unidos vive en el área metropolitana de Miami-Fort Lauderdale-West Palm Beach que se extiende sobre los tres condados del sur de Florida: Miami-Dade, Broward, Palm Beach (U.S. Census Bureau, 2019). ${ }^{138}$

138. Excepto cuando se haga referencia explícita a otra fuente estadística, todas las cifras presentadas en el análisis siguiente se refieren al American Community Survey 2019 del Censo 
Los haitianos de Miami: ¿una comunidad en vías de integración?

Nuestro análisis del perfil social de los haitianos de Miami-Dade tomará como base la población de ascendencia haitiana estimada en 140.800 personas en 2019 según el censo federal, de las cuales 58\% de los miembros son inmigrantes y $42 \%$ son originarios de Haití nacidos en Estados Unidos. ${ }^{139}$

Además de su concentración geográfica y de su reconocimiento oficial como una "comunidad de interés" según la terminología del Gobierno federal estadounidense, la etnicización de los haitianos por la sociedad de acogida y las autoridades locales se ha llevado a cabo sobre la base de su categorización racial y étnica como una población negra no hispana y no anglófona en una sociedad de acogida mayoritariamente blanca hispana donde la minoría negra era mayoritariamente anglófona. Eso también tiene implicaciones en la territorialización de la comunidad haitiana. La casi totalidad de los haitianos (98\%) están clasificados como "negros o afroamericanos" en el censo, en una sociedad de acogida en la que los individuos autodeclarados blancos representan las tres cuartas partes de la población local, es decir, algo más de 2 millones de personas, y los negros apenas menos de $17 \%$ de la población. Anteriormente hemos observado que, en este espacio urbano todavía marcado por la herencia de la segregación, la asignación racial tenía repercusiones en la localización residencial de las poblaciones en el espacio metropolitano.

$\mathrm{Al}$ igual que en otras ciudades de Estados Unidos, se han combinado tres factores principales para explicar la creación de espacios residenciales blancos y negros diferenciados y el acceso limitado de los negros al mercado de la vivienda en Miami: los prejuicios de los hogares blancos anglos con respecto a los hogares negros, las estrategias discriminatorias de los agentes inmobiliarios y las discriminaciones federales en la concesión de préstamos inmobiliarios en detrimento de las zonas residenciales mixtas (Massey y Denton, 1993; Audebert, 2006). Por cierto, una de las particularidades de Miami es que su población está clasificada mayoritariamente como hispana o latinoamericana $(70 \%)$ y que, por esta razón, existe un tercer mercado inmobiliario relativo a la presencia hispánica y que afecta a dos tercios del espacio urbano en el suroeste y el oeste

estadounidense (US Census, 3-year ACS).

139. Excepto cuando se haga referencia explícita a los inmigrantes en el texto. 
de la metrópolis y al que los negros no hispanos, incluidos los de Haití, prácticamente no tienen acceso. Por tanto, la experiencia de inserción de los haitianos en el mercado de la vivienda de Miami está marcada por un doble proceso de segregación.

Cabe mencionar que, dentro de las "zonas residenciales negras", los haitianos han tendido a instalarse en zonas distintas a las de los afroestadounidenses. A finales de los años 70, los mecanismos de la segregación espacial explicaron que se instalaron en o cerca de los "barrios negros" norteamericanos. Sin embargo, luego se fueron alejando progresivamente de estos barrios, cuando la lógica de la agregación espacial y de la agrupación comunitaria acompañando el crecimiento demográfico del grupo prevaleció en los años 80. Al fin y al cabo, la triple minorización de la población haitiana explica que su espacio residencial se limita al sector noreste de la aglomeración de Miami, donde se localizan los negros no hispanos de la ciudad. Se trata principalmente de barrios pobres, cuyos residentes afrocaribeños y afroestadounidenses están principalmente insertados en la parte inferior de la escala socioeconómica, como lo ilustra la situación de los haitianos. El hecho comunitario ha sido reforzado por una conciencia de clase en los barrios populares haitianos de Miami. En la Pequeña Haití, la etnicidad se ha articulado con la identidad de clase para hacer de la comunidad de Miami uno de los centros de la movilización política en favor de los derechos de los migrantes haitianos en Estados Unidos.

Herencia de la migración en barco de indocumentados procedentes de las zonas rurales más marginadas de Haití, la población de Miami sigue siendo hoy día la más pobre de las comunidades haitianas de América del Norte. La tasa de pobreza de $18 \%$ de los inmigrantes haitianos de Miami es muy superior a la media de los haitianos en Estados Unidos (de $13 \%)$, una situación relacionada con las diferencias en los niveles de ingresos individuales medios: 23.700 dólares para los inmigrantes haitianos de Miami-Dade, en comparación con 30.520 dólares para sus compatriotas en todo el país en 2019. El perfil social específico de los haitianos de Miami está en gran parte ligado al modo de migración por vía marítima de una gran parte de ellos, que se explica por la situación geográfica de Florida a las puertas del Caribe.

En el plano local, cuando comparamos las personas de ascendencia haitiana (es decir, los inmigrantes y sus descendientes nacidos en Estados 
Unidos) con grupos de otras ascendencias étnicas o nacionales que viven en Miami-Dade, las diferencias siguen siendo perceptibles. Al nivel individual, el ingreso individual medio de las personas de ascendencia haitiana, de 17.540 dólares en 2019, seguía siendo un tercio inferior al promedio de los grupos latinoamericanos (26.816 dólares) y más de tres veces inferior al de los blancos no hispanos (55.600 dólares). También estaba por debajo de los ingresos medios de los negros no hispanos y el único grupo étnico-nacional con ingresos menores era el hondureño. Ello se explica por el origen social desfavorecido de una parte importante de esa población en Haití, su escaso capital social y educativo de partida, y sus efectos sobre la relativa concentración del grupo en determinados sectores profesionales entre los menos remunerados de la economía local. El 35\% de la población de ascendencia haitiana en Miami trabaja en hostelería, restauración, entretenimiento y comercio minorista cuyos ingresos medios se sitúan entre 26.000 y 31.000 dólares. El espacio comercial se ha desarrollado mucho en los barrios haitianos de Miami, pasando de cerca de 200 comercios a mediados de los años 80 a más de 500 en los años 2000 (Stepick, 1984; Audebert 2006 y 2013). La mayoría de los comerciantes siguieron operando, al menos parcialmente, en el sector informal, y el tejido económico empresarial haitiano estaba menos diversificado e integrado en la economía local que el de los cubanos y otros latinoamericanos.

\section{La transformación social de la comunidad haitiana de Miami}

Los fundamentos históricos y culturales de la comunidad haitiana, su origen social, sus modalidades de migración y de acogida en Florida explican su cohesión social, su concentración espacial y su inserción en la parte inferior de la escala socioeconómica local. Al mismo tiempo, ha experimentado importantes transformaciones en los últimos decenios, debido a su fuerte crecimiento demográfico, sus notables cambios sociales, su integración en el tejido económico y el acceso de los originarios de Haití a la ciudadanía del país de acogida.

Una de las principales raíces de la evolución del lugar de este grupo en la sociedad y en el espacio de Miami es la expansión rápida de su población. Desde su aparición en el decenio de 1970, la presencia haitiana no ha dejado de crecer en el sur de Florida, gracias a flujos migratorios que se han 
renovado constantemente. A las corrientes de boat people se han añadido otras migraciones haitianas cuyos orígenes regionales y sociales se han diversificado. Además, otros haitianos que habían estado presentes en otras partes de Estados Unidos (Nueva York, Boston) vinieron a unirse a ellos. En la última década (2010-2019), los tres condados del área metropolitana de Florida del Sur han acogido a 70.000 nativos haitianos, lo que la convierte en la segunda población inmigrante después de la de Cuba. Durante ese período, uno de cada diez inmigrantes que llegaron a la región procedía de Haití. Más de la mitad de la población inmigrante haitiana residente en el condado de Miami-Dade llegó después de 2000, y casi uno de cada cuatro inmigrantes se ha asentado en los últimos diez años. Así pues, la inmigración que proviene de Haití es muy dinámica y se renueva constantemente.

Esta dinámica recuerda la de los primeros tiempos del asentamiento de los haitianos: casi dos tercios de los inmigrantes registrados en Miami en 1990 habían llegado al país en los quince años anteriores (US Census, 1993). El otro factor determinante del crecimiento demográfico es la natalidad, que sigue siendo relativamente alta en comparación con otras poblaciones. En promedio, los niños representan $40 \%$ de la población de los hogares haitianos, frente a 30\% de la composición de los hogares censados en la población total del condado.

La combinación del crecimiento natural y la inmigración sostenida mantiene la edad mediana en un nivel relativamente bajo, con flujos migratorios en los que los adultos jóvenes en edad de procrear están sobrerrepresentados. La edad media de los haitianos, de 33 años, es claramente inferior a la de los grupos etno-nacionales más importantes de la ciudad (47 años para los cubanos, 41 años para los colombianos, 40 años para los cubanos y los blancos no hispanos), y más generalmente a la de la metrópoli (40,5 años). Otro efecto de la dinámica demográfica sobre las transformaciones sociales en el seno de la comunidad es el peso creciente de las generaciones nacidas en Estados Unidos, que representan casi la mitad de la población de ascendencia haitiana en Miami.

La importancia de la familia en la estructuración de la comunidad haitiana se expresa en su función crucial en varios ámbitos: la acogida y la inserción social de los familiares que han inmigrado recientemente, la cohabitación frecuente de dos o tres generaciones en el seno de un mismo hogar, y la activación de las redes migratorias regionales, y la activación 
de las redes migratorias regionales y de aldea en el marco de la concepción de la familia ampliada haitiana (acogida de vecinos y amigos). Esto explica el tamaño medio relativamente grande de los hogares haitianos, de cuatro personas, en comparación con la población general de Miami-Dade (tres personas). A escala de la comunidad, esto explica también la superpoblación de los barrios donde se instalan, su alta concentración residencial, y su rápida expansión geográfica, como analizaremos más adelante.

A pesar de una situación social relativamente desfavorable con respecto a los criterios de la sociedad de acogida, de los efectos de la crisis inmobiliaria y económica de 2007 en Estados Unidos y de las consecuencias a largo plazo del terremoto haitiano de 2010 sobre la pauperización de las familias transnacionales, los haitianos de Florida han registrado un progreso social real a largo plazo que demuestra su inserción progresiva en la sociedad local. Esta dinámica social se observa tanto en el tiempo como de una generación a otra. El acceso a la educación es uno de los principales factores del ascenso social de los haitianos en la sociedad estadounidense. El capital humano y social que crea amplía las oportunidades de inserción profesional y permite acceder a la prosperidad económica. En Miami-Dade, la proporción de haitianos con un nivel de estudios inferior al equivalente de la Selectividad pasó de la mitad a una cuarta parte de las personas mayores de 25 años entre 2000 y 2019, mientras que la de los haitianos con nivel universitario pasó de 31\% a 44\% según el Censo (U.S. Census, 2000; U.S. Census Bureau, 2019). ${ }^{140}$ En la diáspora, esta evolución es fruto de estrategias familiares más que individuales, que dan prioridad a la educación. Una pauta común es la de los padres inmigrantes con un nivel de instrucción básico y sin diploma, cuyos hijos van accediendo a los estudios superiores en el sistema académico norteamericano y a la clase media.

La dinámica a la que se asiste no es tanto la de un éxito social personal de los inmigrantes como la de una ascensión social intergeneracional. Se traduce en una disminución de la pobreza de sus hijos en la edad adulta

140. Aunque ambas fuentes provengan del Censo oficial estadounidense, cabe mencionar que la comparación del censo de 2000 con la encuesta nacional de 2019 debe hacerse con precaución, dado que sus metodologías son diferentes. No obstante, la encuesta nacional de 2019 sigue siendo la fuente estadística oficial más reciente sobre los haitianos en EE. UU. que ahora está disponible. 
y en una diversificación de su posicionamiento socio-profesional. Cuando se compara la población de ascendencia haitiana, que comprende a los inmigrantes y las generaciones nacidas en Estados Unidos, con la población únicamente inmigrante, parece que el primer grupo está más presente en las actividades que tienen responsabilidades e intelectuales y en las actividades terciarias cualificadas que el segundo grupo. La mediana de los ingresos de los hogares haitianos de 44.200 dólares sigue siendo muy inferior a la del condado (55.200 dólares), pero ha crecido más rápidamente que esta última en los dos últimos decenios.

En el plano cultural, la diversificación de la composición social de los flujos y de la experiencia migratoria de los haitianos, más urbanos que antes y que a veces vivieron en otros lugares de la diáspora antes de instalarse en Miami, ha complejizado el perfil de la comunidad. Sin embargo, el elemento que más ha contribuido a la diversificación socio-cultural de esta población es sin duda la expansión del peso relativo de las generaciones nacidas en Estados Unidos. El dominio del inglés por dos tercios de la población de ascendencia haitiana paralelamente al del criollo traduce el cosmopolitismo de las generaciones que crecieron en Estados Unidos. ${ }^{141}$ Al mismo tiempo, los nacimientos fuera del matrimonio más frecuentes en este grupo $-44 \%$ del total de nacimientos en el último año- reflejan una evolución de las prácticas socioculturales en Florida.

En el plano legal, los obstáculos para el reconocimiento oficial de su presencia en Florida hasta los años 80 dificultaron el acceso de los haitianos a la residencia legal y, por tanto, a la ciudadanía estadounidense. El creciente número de inmigrantes que van accediendo a esta ciudadanía es, por consiguiente, un indicador importante de su integración en esta sociedad. En 2019, 57\% de los 81.800 nativos de Haití censados en el condado de Miami-Dade eran ciudadanos estadounidenses, una proporción inversa a la observada en 1990, donde 60\% de los inmigrantes eran ciudadanos de Haití (U. S. Bureau of the Census, 1993; U. S. Census Bureau, 2019). Esta opción simbólicamente fuerte por la naturalización se produce en el contexto de una pérdida de esperanza en el futuro de Haití y de la voluntad de implicarse en los asuntos políticos de la sociedad de

141. Dos tercios de la población de ascendencia haitiana afirmaban hablar "muy bien" inglés en 2019, frente a 48\% de la población nacida en Haití. 
Los haitianos de Miami: ¿una comunidad en vías de integración?

acogida. Es también consecuencia del acceso de un número creciente de haitianos a la residencia permanente.

\section{La expansión del espacio residencial haitiano}

La inmigración haitiana a Miami se ha desarrollado de manera continua en los últimos cuatro decenios y su comunidad ha adquirido una gran visibilidad que se traduce tanto en términos demográficos como en el plano de la estructuración social y de la territorialización urbana. La presencia creciente de los haitianos en el espacio responde a las fases sucesivas del crecimiento demográfico del grupo y a las mutaciones sociales que lo han acompañado.

La primera fase se refiere a la conformación de una comunidad haitiana caracterizada geográficamente por la creación del barrio de la Pequeña Haití a comienzos del decenio de 1980 y su estructuración progresiva a lo largo del decenio. En la segunda fase, desde finales de los años ochenta hasta nuestros días, ha sido la de un doble movimiento de la comunidad: la estructuración de la Pequeña Haití como el centro inicial de la comunidad, y la rápida expansión espacial de los haitianos hacia el norte, donde ha aparecido un nuevo centro de estructuración de la comunidad en North Miami. Tras las olas de boat people de 1977 a 1981, durante las cuales llegaron entre 50.000 y 70.000 migrantes haitianos a Florida (Alex Stepick, 1992), su concentración en los barrios centrales de Miami tomó un giro inédito y constituyó 40\% de la población de Edison-Little River en 1982 (Ladner et al., 1983). Su concentración voluntaria en esta zona rebautizada como la Pequeña Haití (Little Haiti) fue también el fruto de lógicas de segregación.

En efecto, al sur del barrio se encuentra la zona puertorriqueña de Wynwood, donde residen poblaciones latinoamericanas pobres, y Overtown, uno de los guetos afroestadounidenses más pobres del país. Los haitianos no tienen posibilidad de ampliar su presencia en esos barrios ya superpoblados y poco atractivos. Al suroeste de Little Haiti, el barrio Allapattah ofrece también pocas posibilidades de instalación, ya que ya es objeto de una dura competición espacial entre los grupos hispanos más pobres (centroamericanos, cubanos, dominicanos) y los afroestadounidenses. Al oeste de Little Haiti, las posibilidades de expansión espacial de los haitianos están limitadas por la hostilidad de los negros del gueto de 
Liberty City. Los afroestadounidenses albergan un resentimiento hacia los haitianos, a quienes acusan de haber contribuido a limitar su inserción económica y su expansión espacial en un contexto de fuerte competencia profesional y espacial entre los dos grupos en el período 1970-1980, tras la desegregación racial. La autopista I-95, entre los dos barrios, constituye una de las fronteras más herméticas de la ciudad. Las oportunidades de expansión en el norte y el este del barrio también se ven limitadas por la presencia de zonas residenciales de clase media y alta blanca que cobran alquileres prohibitivos (Biscayne Bay, Miami Shores).

La concentración espacial en la Pequeña Haití se ha traducido en una estructuración social a lo largo de la década de 1980, especialmente en el momento de la estabilización de la presencia de los inmigrantes tras la regularización de su situación en 1986 y la instalación de servicios sociales por el condado, el estado de Florida y el Gobierno federal. Entonces surgieron en la comunidad una serie de lugares estructurantes en el plano administrativo, escolar, religioso y cultural. El Ayuntamiento de Miami instaló una antena, y las escuelas públicas del condado aparecieron como lugares de estructuración de la comunidad. La escuela secundaria afroestadounidense de Edison fue acogiendo progresivamente a una población escolar mayoritariamente haitiana en el decenio de 1980 y se estableció como un importante lugar de expresión cultural y deportiva de la juventud haitiana de Miami. Una escuela primaria fue inaugurada y bautizada con el nombre simbólico de Toussaint Louverture, héroe de la independencia haitiana. El rol social y comunitario muy importante de las iglesias en la estabilización geográfica de la comunidad ya se ha mencionado, y en otros lugares he desarrollado un análisis exhaustivo de esta cuestión (Audebert, 2002). La construcción de lugares culturales centrales como el mercado de hierro (mache anfè) y el centro cultural haitiano han contribuido a estructurar la comunidad al dinamizar su actividad económica. El mercado de hierro, que sigue el modelo arquitectural del gran mercado de Puerto Príncipe, tiene una doble dimensión económica y cultural para los haitianos. Por su arquitectura típicamente haitiana, constituye a la vez un marcador geográfico y un centro comercial, turístico y de encuentro comunitario. El centro cultural de la Pequeña Haití acoge manifestaciones sociales y culturales (exposiciones literarias, de pintura, conciertos, etc.) que contribuyen a la difusión de la cultura haitiana en Florida. 
A partir de finales de los años 80 , la creciente presión demográfica en el barrio y los cambios socio-económicos y etnoculturales de los barrios adyacentes crearon un doble movimiento: la expansión espacial de los haitianos hacia el norte y la instalación creciente de poblaciones no haitianas en la "pequeña Haitî" bajo el efecto de la gentrificación. A principios de los años 90, los hispanos se convirtieron en mayoría en Miami. Frente a la hispanización de la ciudad, los blancos no hispanos comenzaron a dejar las zonas residenciales alrededor de North Miami para instalarse más al norte en los condados mayoritariamente anglos de Broward y Palm Beach. Su percepción de Miami era entonces cada vez más la de un enclave hispano-americano en territorio estadounidense.

En este contexto, grandes zonas residenciales con viviendas de mejor calidad que las de la Pequeña Haití quedaron vacías. El costo de las residencias bajó y los haitianos pudieron instalarse allí. La población negra de esta zona del noreste del área metropolitana, aquí principalmente haitiana y afroestadounidense, experimentó un aumento exponencial a partir de los años 80. Entre 1980 y 1990, su peso relativo en la población aumentó de $4 \%$ a $32 \%$ en North Miami, de $1 \%$ a $20 \%$ en Miami Shores y de $0 \%$ a $22 \%$ en North Miami Beach. La tendencia se intensificó durante los años 90 y después del año 2000. Los nuevos residentes haitianos arrastraron a otras poblaciones afrocaribeñas (en particular, jamaiquinas) a estos barrios blancos suburbanos de clase media. North Miami se convirtió en el otro polo residencial haitiano de Miami-Dade. Allí fue elegido en 2000 el primer alcalde haitiano de una ciudad de más de 50.000 habitantes en Estados Unidos y la comunidad haitiana ahora se impone como la primera fuerza política local en esta localidad (Audebert, 2009). En aquel momento vimos en él el signo de una desegregación y de una mejor integración económica para los haitianos. En este sentido, es tentador establecer un paralelismo con la evolución social y espacial de la comunidad cubana desde comienzos de los años sesenta. En efecto, a medida que se sucedieron las oleadas migratorias, los cubanos ampliaron rápidamente su territorio residencial desde el enclave étnico de la Pequeña Habana hacia Hialeah y luego hacia el oeste, el noroeste y el sur de la metrópoli. Al hacerlo, crearon un vasto espacio residencial hispano-americano que constituyó un ambiente favorable para la acogida posterior de otras poblaciones. En la actualidad, los puertorriqueños, colombianos, hondureños, nicaragüenses, dominicanos, 
peruanos, venezolanos, panameños y mexicanos se han asentado cada vez más en esas zonas. Estos barrios se convirtieron también en el marco geográfico del desarrollo de una economía étnica cubana e hispana diversificada y al mismo tiempo bastiones electorales para alcaldes, diputados locales y senadores federales latinoamericanos (Wilson y Portes, 1980; Grenier y Stepick, 1992; Portes y Stepick, 1993). Sin embargo, lo que se dibujó en los nuevos barrios haitianos fue más bien una extensión del espacio residencial de las familias negras pobres y, al fin y al cabo, una extensión espacial del proceso de segregación social y racial. La mayoría de las familias blancas abandonaron la zona y North Miami —donde vivían 25.000 haitianos en 2015 - se convirtió en la principal ciudad haitiana de Florida, delante de la Pequeña Haití de Miami y sus 17.000 haitianos. ${ }^{142}$

Al mismo tiempo, la Pequeña Haití, aunque sigue siendo el centro cultural de la comunidad haitiana de Miami, ha acogido a otros grupos inmigrantes recientes, principalmente caribeños y latinoamericanos. También ha conocido un proceso de gentrificación en un contexto de "reconquista" de los barrios centrales por las capas sociales más ricas de Miami. Por tanto, en la actualidad se asiste a un desplazamiento del centro de gravedad de la comunidad haitiana hacia la periferia, particularmente hacia el norte del condado.

\section{Conclusión}

En definitiva, más de medio siglo de migración masiva desde el Caribe y América Latina ha transformado notablemente el entorno cultural, social y económico de Miami. La ciudad es hoy una de las más internacionales de Estados Unidos y, junto con Nueva York, una de las dos grandes ciudades del mundo Atlántico en el país. La presencia haitiana creciente ha hecho una contribución importante a esta dinámica de "caribización". Sin embargo, su experiencia espacial urbana y sus relaciones con otras comunidades culturales demuestran que la multiculturalidad de la ciudad vinculada a la migración no ha ido acompañada de un cuestionamiento fundamental de la distancia social y espacial entre los grupos. El área metropolitana de Miami sigue marcada en gran medida

142. Fuente: US Census, 2015 3-year American Community Survey (ACS). 
por la segmentación social, cultural y geográfica. Pocos haitianos viven en barrios latinos o blancos no hispanos, y la mayoría de ellos siguen concentrados en un número limitado de lugares bien identificados, a pesar de su presencia en la ciudad desde hace varias generaciones.

Las características sociales, culturales y raciales de los haitianos de Miami y el hecho de que estas sean comunes a la gran mayoría de ellos han conferido originalidad y cohesión a esta comunidad. A estos elementos internos de estructuración comunitaria se añaden elementos externos propios de la sociedad de recepción. Estos han podido contribuir a la integración social, como la intervención de las instituciones religiosas y políticas locales en favor del reconocimiento de los derechos de los refugiados. También pueden tener el efecto contrario, como lo demuestran los prejuicios que aún existen entre la población local, la persistencia de la segregación y sus efectos perniciosos

No ha sido fácil para los haitianos encontrar su lugar en este salad bowl antitético del melting pot. No obstante, después de cuatro décadas de presencia, el proceso de inserción social es muy real. Su notable dinámica demográfica y socioeconómica desde la segunda mitad del decenio de 1980 se ha traducido en una expansión de su territorio en la ciudad. La organización de esta comunidad alimentada por una inmigración cada vez más renovada se encarnó en el espacio por la creación del enclave central de la Pequeña Haití y luego por una difusión residencial hacia el norte de la metrópoli.

Lejos de limitarse al condado de Miami-Dade, el espacio residencial haitiano se ha desarrollado en todo el sur de Florida en los últimos cincuenta años. La multiplicidad de comunidades haitianas que lo constituyen se extiende a lo largo de más de cien kilómetros por la costa atlántica, en los tres condados de Miami-Dade, Broward y Palm Beach. A las puertas del Caribe, se han convertido en la principal concentración haitiana de Estados Unidos y hoy se afirman como una pieza central del espacio migratorio regional caribeño. Han participado sin duda en la "caribización" de Florida. Al mismo tiempo, en este espacio, la presencia haitiana ha abierto un nuevo espacio para otras poblaciones migrantes caribeñas de habla criolla (13 millones de personas hablan kreyòl en al menos ocho países o territorios del Caribe) que ahora encuentran en Florida un entorno familiar para el desarrollo de su cultura y de su territorio lingüístico. 
Cédric Audebert,

\section{Referencias}

Allman, T. D. (1987). Miami: City of the future. Nueva York: Atlantic Monthly Press.

Allman, T. D. (2015). Miami est l'Amérique. Entretien avec Philippe Letrillart. Problèmes d'Amérique latine, 96-97, 123-131.

Anglade, G. (1982). Atlas critique d'Haïti. Montréal: Centre de Recherches Caraïbes, Université de Montréal.

Audebert, C. (2002). Le fait religieux dans l'insertion et l'organisation spatiale de la communauté haïtienne de Miami. Géographie et Cultures, (43), 107-127.

Audebert, C. (2006). L'insertion socio-spatiale des Haïtiens à Miami. París: L'Harmattan.

Audebert, C. (2009). Residential patterns and political empowerment among Jamaicans and Haitians in the U.S. metropolis: The role of ethnicity in Nueva York and South Florida. Human Architecture, 7(4), 53-68.

Audebert, C. (2012). La diaspora haïtienne: territoires migratoires et réseaux transnationaux. Rennes: Presses Universitaires de Rennes.

Audebert, C. (2013). Spatial Strategies of Haitian Businesses in the Diaspora: The Case of Metropolitan Miami (2001-2009). Journal of Haitian Studies, 19(1), 217-234.

Audebert, C. (2015). Miami, métropole-carrefour des Amériques. Réflexions à partir de l'expérience migratoire haitienne. Problèmes d'Amérique latine, (96-97) 105-121.

Audebert, C. (2020). Caribbean Spaces of Migration and Transnational Networks: The Case of the Haitian Diaspora. En M. Moïse R. Fred (eds.), Border Transgression and Reconfiguration of Caribbean Spaces (pp. 71-93). Nueva York: Palgrave MacMillan; Springer Nature.

Basch, L.; Glick Schiller, N. y Szanton Blanc, C. (1994). Nations unbound: Transnational projects, postcolonial predicaments and deterritorialized nation-states. Nueva York y Londres: Routledge.

Boswell, T.D. (ed). (1991). South Florida: the winds of change. Miami: Association of the American Geographers.

Boswell, T. D. (ed). (1994). The cubanization and hispanicization of metropolitan Miami. Miami: Cuban American National Council.

Buchanan Stafford, S. (1992). The Haitians: The cultural meaning of race and ethnicity. En N. Foner (ed.), New immigrants in New York City (pp. 131-158). Nueva York: Columbia University Press..

Castor, S. (1971). La ocupación norteamericana de Haití y sus consecuencias (1915-1934). México: Siglo Veintiuno. 
Los haitianos de Miami: ¿una comunidad en vías de integración?

Craton, M. (1995). The Bahamian self and the Haitian other: The migration of Haitians to and through the Bahamas, 1950-2000. Immigrants and Minorities, 14(3), 265-288.

Deckelbaum, Y. (1983). Little Haiti: the evolution of a community (tesis de maestría no publicada). Atlantic University, Boca Ratón, Florida, Estados Unidos.

Girault, G. (2003). Miami, capitale du bassin caraïbe? Mappe Monde, 72(4), 29-33.

Girault, G. (2015). La métropole de Miami. Dynamiques de croissance et projection régionale et mondiale. Problèmes d'Amérique latine, (96-97), 39-62.

Glick Schiller, N. y Fouron, G. (1999). Terrain of blood and nation: Haitian transnational social fields. Ethnic and Racial Studies, 22(2), 340-366.

Glick Schiller, N. y Fouron, G. (2001). George Woke Up Laughing: Long-Distance Nationalism and The Search for Home. Durham, Carolina del Norte: Duke University Press.

Global Cities Initiative (2012). A statewide roundtable: Goods movement \& the global economy. Miami: Brookings Metropolitan Policy Program.

Grenier, G. y Stepick, A. (eds.). (1992). Miami now! Immigration, ethnicity and social change. Gainesville: University Press of Florida.

Grosfoguel, R. (1997). Migration and geopolitics in the Greater Antilles: From the cold war to the post-cold war. Review (Fernand Braudel Center) 20(1), 115-145.

Hurbon, L. (1987). Culture et dictature en Haïti: l'imaginaire sous contrôle. Puerto Príncipe: Deschamps.

Jackson, R. O. (ed.). (2011). Geographies of the Haitian diaspora. Nueva York y Oxon: Routledge.

Joint, L. A. y Mérion, J. (eds). (2011). L'immigration haïtienne dans la Caraïbe: Quel défi pour l'unité des peuples? Pointe-à-Pitre: Nestor.

Ladner, $\mathrm{R}$ et al. (1983). Demography, social status, housing and social needs of the Haitian population of Edison-Little River. Coral Gables: University of Miami.

Laguerre, M. (1998). Diasporic citizenship: Haitian Americans in transnational America. Nueva York: St Martin's Press.

Lemoine, M. (1981). Sucre Amer. París: Encre.

Lundhal, M. (1982). A note on Haitian migration to Cuba: 1890-1934. Cuban Studies, 12(2), 21-36.

Marshall, D. (1979). The Haitian problem: Illegal migration to the Bahamas. Cave Hill: Institute of Social and Economic Research.

Massey, D. y Denton, N. (1993). American apartheid: segregation and the making of the underclass. Cambridge y Londres: Harvard University Press. 
Cédric Audebert,

Mohl, R.A. (1991). The settlement of Blacks in South Florida. En T. Boswell (ed.), South Florida: the winds of change (pp. 112-139). Miami: Association of the American Geographers.

Nijman, J. (2000). The paradigmatic city. Annals of the Association of American Geographers, 90(1), 135-145.

Nijman, J. (2010). Miami, Mistress of the Americas. Philadelphia: University of Pennsylvania Press.

Pedraza-Bailey, S. (1985). Cuba's exiles: Portrait of a refugee migration. International Migration Review, 19(1), 4-34.

Perry, C. (2014). Invasion from The South: Social Construction of the Haitian "Other" in the Bahamas. International Journal of Bahamian Studies, 20(1), 1-12.

Perusek, G. (1984). Haitian emigration in the early twentieth century. International Migration Review, 18(1), 5-18.

Pierre-Louis, F. (2006). Haitians in Nueva York City: Transnationalism and hometown associations. Gainesville: University Press of Florida.

Portes, A. y Stepick, A. (1985). Unwelcome immigrants: The labor market experiences of 1980 Mariel Cuban and Haitian refugees in South Florida. American Sociological Review, 50(4), 493-514.

Portes, A. y Stepick, A. (1993). City on the edge: the transformation of Miami. Berkeley: University of California Press.

Stepick, A. (1981). Structural determinants of the Haitian refugee movement: Different interpretation. Miami: Latin American and Caribbean Center, Florida International University.

Stepick, A. (1982). Haitian boat people: a study in the conflicting forces shaping U.S. immigration policy. Law and Contemporary Problems, 45(2), 63-196.

Stepick, A. (1984). The business community of Little Haiti. Occasional Papers Series Dialogue, 32. Miami: Latin American and Caribbean Center, Florida International University.

Stepick, A. (1992). The refugees nobody wants: Haitians in Miami. En G. Grenier y A. Stepick (eds.), Miami now! Immigration, ethnicity and social change (pp. 57-80). Gainesville: University Press of Florida.

Stepick, A. (1998). Pride against prejudice: Haitians in the United States. Boston: Allyn and Bacon.

Stepick, A. y Portes A. (1986). Flight into despair: A profile of recent Haitian refugees in South Florida. International Migration Review, 20(2), 329-350.

U. S. Bureau of the Census (1993). 1990 Census of Population and Housing Public Use Microdata Samples. Washington: U.S. Department of Commerce. 
U. S. Census Bureau (2019). 2019 3-Year American Community Survey. Washington: Department of Commerce.

U. S. Census (2000). Census of Population and Housing 2000. Summary File 3. Washington: U. S. Department of Commerce.

U. S. Department of Homeland Security (2020). Yearbook of Immigration Statistics 2019. Washington: Department of Justice, Recuperado de https:// www.dhs.gov/sites/default/files/publications/immigrationstatistics/yearbook/2019/lawful_permanent_residents_2019.pdf

Wilson, K. y Portes A. (1980). Immigrant enclaves: an analysis of the labor market experiences of Cubans in Miami. American Journal of Sociology, 86(2), 295-319. 


\section{Los autores}

\section{Oscar Zanetti Lecuona}

Doctor en Ciencias Históricas. Académico de número de la Academia de la Historia de Cuba y miembro de mérito de la Academia de Ciencias de Cuba. Investigador titular del Instituto de Historia de Cuba y profesor titular de la Universidad de La Habana; en la actualidad trabaja en su Departamento de Historia como profesor a tiempo parcial. Preside el Tribunal Permanente de Grados Científicos en Historia. Premio Nacional de Ciencias Sociales y Humanísticas 2011 y de Historia 2015. Participante en diversos proyectos de investigación internacionales, recibió un Fellowship de la Fundación Guggenheim en 2010 y una residencia de la Fundación Rockefeller en Bellagio, Italia, en 2019. Es miembro honorario extranjero de la Academia Americana de Artes y Ciencias y correspondiente de la Dominicana de la Historia.

Sus trabajos han dado lugar a una docena de libros y otras numerosas publicaciones en revistas científicas. Entre los primeros, Caminos para el azúcar —en colaboración con Alejandro García-, recibió el premio Elsa Goveia de la Asociación de Historiadores del Caribe, y su ensayo Comercio y poder obtuvo el Premio Casa de las Américas en 1998. Sus publicaciones más recientes incluyen los libros Esplendor y decadencia del azúcar en las Antillas hispanas (2012), Historia mínima de Cuba (2013), La escritura del tiempo (2014) y El Caribe: procesos económicos en perspectiva histórica (2018). 
Migraciones antillanas: trabajo, desigualdad y xenofobia

\section{Consuelo Naranjo Orovio}

Profesora de Investigación del Instituto de Historia del Consejo Superior de Investigaciones Científicas y directora de Culture \& History Digital Journal. Su investigación se centra en la historia social y cultural del Caribe de los siglos XIX y XX. Es miembro extranjero correspondiente de la Academia de la Historia de Cuba, la Academia Mexicana de Ciencias y la Academia Dominicana de la Historia. Ha impartido seminarios en diferentes universidades de Estados Unidos, Francia, México, Puerto Rico, Cuba, República Dominicana, Colombia, Chile, Brasil, etc. Es directora de la colección de Historia de las Antillas (2009-2014).

Los estudios los ha realizado en el marco de 27 proyectos financiados por instituciones oficiales (1990-2019), 17 como investigadora principal y 10 como miembro de proyectos nacionales e internacionales. Los resultados han aparecido en monografías (Racismo e inmigración en Cuba, siglo XIX; Medicina y racismo en Cuba. La ciencia ante la inmigración canaria, siglo XX; El rumor de Haití en Cuba: temor, raza y rebeldía, 1789-1844); libros colectivos, muchos de los cuales ha coordinado (Ciencia y Fascismo; The Cuban Republic and Jose Marti: Reception and Use of a National Symbol; Saint-Domingue espagnol et la révolution nègre d'Haïti; La Nación soñada: Cuba, Puerto Rico y Filipinas ante el 98; Imágenes e imaginarios; Imaginarios del miedo. Estudios desde la historia; Kaléidoscopes coloniaus. Transferts culturels Dans les Caraïbes au XIXe siècle; Worldwide/Weltweit. Archipele als Erprobungsräume globalen ZusammenLebens) y revistas científicas internacionales de alto impacto.

Entre sus últimas publicaciones se encuentran Slavery and the African cultural legacy in the Caribbean (2020); The Caribbean, Origin of the Modern World, (2019); Esclavitud y diferencia racial en el Caribe hispano (2017); Historia minima de las Antillas. Las Antillas hispanas y las Antillas británicas. Dos modelos de colonización en el Caribe (2014 y 2017); Fernando Ortiz. Estudio crítico (2016); El eterno retorno: exiliados republicanos españoles en Puerto Rico (2011); Imaginarios del miedo. Estudios desde la Historia (2013). En la actualidad lidera el proyecto europeo Connected Worlds: The Caribbean, Origin of the Modern World (Research and Innovation Staff Exchange (RISE) H2020-MSCA-RISE-2018), (2019-2024). 
Migraciones antillanas: trabajo, desigualdad y xenofobia

\section{Jorge Enrique Elías-Caro}

Presidente de la Asociación de Historia Económica del Caribe (AHEC) y vicepresidente de las Asociaciones de Historiadores Latinoamericanos y del Caribe (ADHILAC) y Colombiana de Estudios del Caribe (ACOLEC). Profesor titular de la Universidad del Magdalena, en donde además ejerce como vicerrector de Investigación y director del Grupo de Investigación "Historia Empresarial y Desarrollo Regional", Categoría A1. Investigador senior del Sistema de Ciencia, Tecnología e Innovación de Minciencias (Colombia). Es docente visitante a nivel de maestrías y doctorados en varias universidades de Europa y América Latina. Doctor en Ciencias Históricas y máster en Historia Contemporánea, mención Estudios Latinoamericanos por la Universidad de La Habana; magíster en Administración de Empresas por la Universidad del Norte (Colombia). Ha realizado estancias postdoctorales en Patrimonio en la Universidad de Huelva (España) y en Historia Económica de América Latina en la Pontificia Universidad Católica de Sao Paulo PUCSP (Brasil). Ha publicado libros, capítulos de libros y artículos científicos en revistas académicas arbitradas e indexadas de Alemania, Inglaterra, España, Austria, Dinamarca, Portugal, Estados Unidos, México, Brasil, Cuba, Chile, Venezuela, Panamá, Honduras, República Dominicana, Argentina, Paraguay, Costa Rica, Ecuador y Colombia. Es miembro de comités editoriales y asesor científico de revistas científicas, culturales e institucionales en varios países de Europa, Norte América, América Latina y el Caribe. Es presidente de la Cátedra Internacional sobre Estudios del Caribe. Miembro honorario de la Cátedra Internacional "Nuestra América" de la UNESCO. Miembro de la Junta Directiva Internacional de la Sociedad Mundial de Investigación y Cultura sobre América Continental y el Circuncaribe. KONAK. Par Evaluador Internacional del Programa Iberoamericano de Ciencia y Tecnología para el Desarrollo (CYTED) en áreas sobre Desarrollo, Ciencia y Sociedad.

\section{Diana Senior Angulo}

Costarricense, humanista y afrodescendiente. Nacida en San José, realiza estudios en Ciencias Políticas en la Universidad de Costa Rica, los 
cuales culmina en 2001. Ese mismo año ingresa al Posgrado Centroamericano en Historia, de la cual obtiene el título de Maestría Académica en Historia en 2007. Luego, se reincorpora a la Universidad de Costa Rica, ya no como administrativa, sino como docente e investigadora. Ha impartido lecciones en Sedes Regionales, la Escuela de Ciencias Políticas y la Escuela de Estudios Generales de su Alma Máter. En 2011, fue becada para realizar sus estudios doctorales en la Université Sorbonne Nouvelle, en París, Francia, de la cual regresa en 2015 con un Doctorado en Historia Contemporánea. Es autora de distintos artículos y textos, entre los que destaca el libro Ciudadanía afrocostarricense: el gran escenario comprendido entre 1927 y 1963, publicado un mes antes de iniciar su doctorado en 2011. Es co-gestora del Canal de YouTube Aportes Afrocostarricenses y Diaspóricos, el cual dio inicio en 2020. Además, es profesora asociada de la Universidad de Costa Rica y desde enero del 2021 fue designada como directora de la Oficina de Asuntos Internacionales y Cooperación Externa (OAICE).

\section{Yesenia Martínez García}

Licenciada en Historia por la Universidad Nacional Autónoma de Honduras (UNAH), Tegucigalpa, 2003; postgrado en Gestión Cultural y Comunicación, FLACSO, Argentina, 2006; maestría académica en Historia, Universidad de Costa Rica, 2013. Estudios de doctorado en Ciencias Sociales, Colegio de Michoacán, Zamora, Michoacán, México, para el ciclo 2017-2022. Actualmente es docente titular II en el Departamento de Historia de la Facultad de Ciencias Sociales, de la UNAH, Tegucigalpa. También ha sido docente en programas de Maestría en Sociología y Maestría en Historia Social y Cultural de la UNAH en Tegucigalpa; en el Diplomado de Educación Superior, Educación a Distancia y Programa de Educación Continua, y Maestría en Bibliotecología en la Universidad Pedagógica Nacional Francisco Morazán, Tegucigalpa; y de Historia de Honduras en la Universidad Nacional de Agricultura, Catacamas, Olancho.

Entre 2006 y 2009, fue jefa de la Unidad de Historia del Instituto Hondureño de Antropología e Historia, y coordinadora del Centro Documental de Investigaciones Históricas de Honduras (CDIHH). Entre 2012 
Migraciones antillanas: trabajo, desigualdad y xenofobia

y 2016, fungió como directora general de Talento Humano y subgerente de Recursos Humanos Docentes, Secretaría de Educación.

Sus temas de investigación están definidos en la Historia Social e Historia Cultural, en los ejes temáticos: Estado-instituciones, la salud pública y poblaciones subalternas. Entre estas se destacan: African Diaspora in

the Educational Programs of Central America (2015); La Seguridad Social en Honduras: actores sociopoliticos, institucionalidad y raíces históricas de su crisis (2015); "La influencia de la Constitución de Cádiz en la concepción de la libertad en Honduras", en Bicentenario de la Constitución de Cádiz en Honduras, en el libro La Constitución de Cádiz y su huella en América (2011).

Ha recibido varios premios y reconocimientos, entre ellos: Premio de Estudios Históricos Rey Juan Carlos I, 2012, que otorga cada año la Embajada de España y la Academia Hondureña de Geografía e Historia en Tegucigalpa, y Premio de Historia Rafael Heliodoro Valle, por la Academia Hondureña de la Lengua, Tegucigalpa, 2020.

\section{Reina Rosario}

Nacida en Bonao, República Dominicana. Es doctora en Historia de Centro América y el Caribe de la Universidad de Costa Rica (UCR). Realizó una licenciatura en Historia y una maestría en Antropología Cultural en la Universidad Estatal de Moscú, Lomonosov (antigua URSS). En el Instituto Tecnológico de Santo Domingo (INTEC) fue decana del área de Ciencias Sociales, y coordinó varias rondas de la Maestría en la Enseñanza de las Ciencias Sociales; allí fundó la Cátedra de Pensamiento Antillanista. Ha sido profesora invitada en varias universidades de norte y sur América.

Dirigió el Departamento de Investigación del Archivo General de la Nación, donde fundó y dirigióla revista educativa Memorias de Quisqueya.

Fue directora del Instituto de Historia de la Facultad de Humanidades y de la revista Ecos, y ha sido y directora del Museo Nacional de Historia y Geografía de la República Dominicana.

Sus líneas de investigación abarcan temáticas como migraciones caribeñas, negritud, antillanismo, identidad y género. Algunos de sus escritos han sido publicados en revistas y libros nacionales y extranjeros. 
Migraciones antillanas: trabajo, desigualdad y xenofobia

Es autora de: El discurso de juramentación presidencial en República Dominicana, 1963-2012 (2014), en coautoría con Manuel Matos Moquete; Identidades de la población de origen jamaiquino en el Caribe Costarricense (2015); Raíces de la identidad dominicana (2015); Desde Bonao, las luchas exitosas de Aniana Vargas (2018), compilación de sus artículos; y Aportes de Abigaíl Mejía a la historiografía dominicana: una feminista volando alto con las alas de Clío (2019).

Es docente investigadora de la Universidad Autonomía de Santo Domingo (UASD).

\section{Juan Santiago Correa Restrepo}

Economista y doctor en Sociología Jurídica e Instituciones Política de la Universidad Externado de Colombia y magíster en Historia de la Pontificia Universidad Javeriana. En la actualidad se desempeña como secretario general en el Colegio de Estudios Superiores de Administración (CESA), donde también es profesor en el pregrado, en el MBA y en la Maestría en Finanzas Corporativas.

Ha publicado múltiples artículos en revistas académicas y es autor de los libros: Minería y comercio: las raíces de la élite antioqueña (17751810) (2001); Territorio y poder: dinámicas de poblamiento en el valle de Aburrá, siglo XVII (2004); Prensa de oposición: el Radicalismo derrotado (1880-1902) (2007); Ferrocarriles y tranvías en Antioquia (2010); Moneda y nación: del federalismo al centralismo económico (1850-1922) (2010); Movilidad en el Caribe: el ferrocarril de Cartagena y el Canal del Dique, siglos XIX y XX (2020); Manual básico para la escritura académica en la universidad (2018); Escritura e investigación académica: una guía para la elaboración del trabajo de grado (2015); entre otros. Las áreas de interés en investigación son la historia económica y empresarial de Colombia y el diseño y aplicación de política pública en educación.

\section{Cédric Audebert}

Geógrafo, director de investigación en el Centro Nacional de Investigación científica (CNRS, Francia), miembro del Centro Caribeño de Ciencias Sociales (CNRS, Universidad de las Antillas Francesas). Dirigió 
Migraciones antillanas: trabajo, desigualdad y xenofobia

el Centro de Investigación CNRS «Migraciones Internacionales, Espacios et Sociedades» (MIGRINTER), y creó la revista cientifica e-migrinter. Es miembro co-fundador del Centro Internacional de Investigaciones sobre la Esclavitud y el Comercio Transatlántico de Esclavos Africanos del CNRS (CIRESC) y fue el ganador 2013 del Premio Internacional de la Asociación de Estudios del Caribe.

Sus investigaciones tratan sobre la territorialización de las migraciones y diásporas caribeñas desde un cuestionamiento sobre el contexto geopolítico, geoeconómico e histórico de esas migraciones y el papel de las metrópolis globales en ese proceso de regionalización y de polarización de los flujos mercantiles, humanos y de capital. Asimismo, aborda sus consecuencias sociales y espaciales en el Caribe, y en las ciudades globales de instalación en EE. UU. y en Europa, a través de su inserción socioeconómica, con relación a los procesos de construcción de la alteridad cultural y de minoración a los que pueden estar sujetos; y de su territorialidad residencial, cultural, económica y política. Ha publicado más de setenta artículos científicos y libros sobre este tema, incluidos L'insertion socio-spatiale des Haïtiens à Miami (2006), La diaspora haïtienne: Territoires migratoires et réseaux transnationaux (2012) y Migration in A Globalised World: New Research Issues and Prospects (2010). 


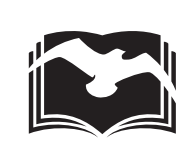

Se diseñó y diagramó en la Editorial Unimagdalena.

Se imprimió en los talleres de Xpress Estudio Gráfico y Digital S.A.S. carrera $69 \mathrm{H}$ núm. 77-40. Bogotá D. C., Colombia.

Esta publicación hace parte de la colección Humanidades y Artes, serie: Historia

En su composición se utilizaron caracteres Minion Pro.

Su portada va en papel propalcote de 300 gramos y las páginas interiores en papel book cream 60 gramos.

Formato $17 \times 24 \mathrm{~cm}$. 